


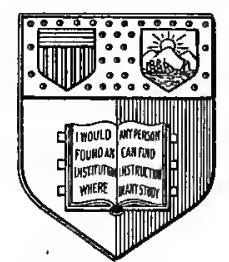

New York

State College of Agriculture At Cornell University Itbaca, N. Y.

\section{Library}




\section{Cornell University Library}

The original of this book is in the Cornell University Library.

There are no known copyright restrictions in the United States on the use of the text.

http://www.archive.org/details/cu31924000680334 



\section{THE PHANEROGAMS OF THE}

\section{JUAN FERNANDEZ ISLANDS}

BY

CARL SKOTTSBERG

Extract from: The Natural History

of Juan Fernandez and Easter Island.

Ed. by Dr. Carl Skottsberg. Vol. II

UPPSALA 1921

ALMQVIST \& WIKSELLS BOKTRYCKERI=A.:B. 



\title{
7. The Phanerogams of the Juan Fernandez Islands.
}

\author{
By \\ CARL SKOTTSBERG.
}

With II plates (nos. 10-20) and 39 text figures.

The compilation of a phanerogamic flora of Juan Fernandez has required more time and labour than could be anticipated. The general belief was, I dare say, that the higher flora of the group was very well known. That the writer did not share this opinion is evident from the fact that floristic investigation was one of the principal objects of the voyage in 1916-17. My short visit in 1908 made me believe that the remote island of Masafuera was a promising field of research. The results communicated below will show, I think, that I was not disappointed. Masatierra, where quite a number of botanists have been, had more in store for us than we expected. There were many places of difficult access only visited by BERTERO, eighty years ago. Our knowledge of the distribution of the species in the islands was, in many cases at least, quite vague, as the earlier collectors seldom recorded the exact localities on their herbarium labels. Several species had been found once or twice only and remained little known.

The starting point for my studies was of course the well known work of F. JoHow. But I had not advanced very far when I found that a reexamination of many of the types was urgently needed. The majority of these had been discovered by BERTERO, and the discrepance between the writer and JoHow concerning several of the species is partly due to the fact that JoHOW had no occasion to study BERTERO's specimens. In other instances his species conception is a little too wide. I found it necessary to examine practically every type of the endemic plants. The collections of Santiago (GermaIN, PHILIPPI, REED a. o. in the herbarium of Museo Nacional, and JoHow's private collection) and Kew (Douglas, Scouler, Bertero, Downton, Moseley a. o.) were studied during longer visits to these places; other material was kindly sent for inspection from Berlin, Kew, Paris, Lund, Stockholm and Upsala.

As usual, several collegues have assisted $m e$ in the determination of my plants. Dr. R. PILGER, Berlin-Dahlem, revised the Gramineae in collaboration with the writer, Dr. C. Lindman, Stockholm, determined some Poae, Rev. Dr. 
G. KÜkenthal, Coburg, revised the Cyperaceae, Dr. G. BitTer, Bremen, made a special study of Solanum, Acaena and Margyricarpus, Mr. O. E. Schulz, Berlin, gave me his opinion on Cardamine, Dr. F VIERHAPPER communicated some notes on my collection of Erigeron, and Dr. H. DAHLSTEDT, Stockholm, described a new form of Taraxacum. To all these gentlemen I wish to express my heartiest thanks for their generous assistance. I also thank Mr. A. KARNELL, Gothenburg, for the help he gave me when preparing the negatives of Plates IO, II, I5 and I7.

Finally, I use this occasion to thank my wife, Mrs. IngA SkotrsberG, for her never failing enthusiasm and her self-sacrifice during a voyage that was a great strain on body and mind alike. She was a most skilful, active and cheerful companion, and contributed largely to the good results of our survey.

The localities in Masatierra are enumerated from E. to W. along the north and south sides of the island, respectively; in the case of Masafuera, they are enumerated from $N$. to $S$. along the east coast and thence round to the west coast, and followed by the observations in the high mountainous region. Spanish names are used, with the following abbreviations: $\mathrm{B} .=$ Bahía, bay; $\mathrm{C}=$ Cordón, mountain ridge; $\mathrm{Co}=$ Cerro, mountain, peak; $\mathrm{Pta}=$ Punta, cape; Pto $=$ Puerto, cove, harbour; $Q .=$ Quebrada, valley with steep sides, gorge, canyon; V. = Valle, valley. Maps will accompany vol. I.

Where a collector's or observer's name is not mentioned, the species has been observed by us in all the places quoted. The numbers in brackets refer to our collection, of which sets are kept in Stockholm (Riksmuseum), Gothenburg (Botanical Garden), Upsala (Museum of the University), and in several foreign herbaria.

A 1 after the name of a collector signifies that I have examined the specimen referred to.

An * before a latin name indicates a new addition to the flora of Juan Fernandez; if before the name of one of the islands, it signifies that the species was observed for the first time in the island in question.

The altitudes are in meters above sea level.

It has been found advisable to indicate the state in which the specimens were collected: $\mathrm{fl} .=$ in flower, $\mathrm{fr} .=$ with fruit. Other abbreviations will be understood without further explanation.

All the illustrations in the text are reproduced after drawings made by the writer.

$$
\text { C. Skottsberg. }
$$

\title{
I. Indigenous species.
}

\author{
Gramineae.
}

Stipa L.

I. S. fernandeziana Phil. Anal. Univ. XLIII.560. - Syn. S. bicolor in Johow, Estud. 134 non Vahl; S. Skottsbergii Pilger ex SkotTsBERG, Stud. 22. Fig. I a-d. 
On dry treeless slopes, also in many places along the high rocky ridges; an important grass in the western half of Masatierra and in the basal region of Masafuera.

Masatierra: Germain! PhILIPPI! - High peak between the colony and Pangal, $365 \mathrm{~m}$; V: Colonial, not uncommon (fl. $5 / 12$ I6, no. 19); Portezuelo de Villagra, $590 \mathrm{~m}$ (fl. ${ }^{3} / 12$ 16, no.: 28 ); C. Salsipuedes (fl.-fr. $8 / 12$ I6, no. $90,{ }^{20} / 12$ I6, no. I70); Q. Juanango; between Villagra and Pta Larga, in many places; but not abundant (fr. $6 / 1$ 1 7 , no. 244).

Masafuera: Probably in all the valleys; $Q$. Seca, abundant; $Q$. de las Casas, very common to a couple of hundred $m$ inland; $Q$. de las Vacas, abundant in the outer parts (fr. $10 / 217$, no. 447).

Leaves to 4 or $5 \mathrm{~mm}$ broad, generally convolute, densely pubescent below, glabrous or with few hairs above. Rays of the panicle about 6 -flowered. Empty glumes very acute, outer 3-, inner 5-nerved, brownish purple with translucent margins and point, $14-15 \mathrm{~mm}$ long in my specimens. Pedicel of flower $3-3,5 \mathrm{~mm}$, densely silky with longer hairs on the ventral side. Floral glume $7 \mathrm{~mm}$ long, with 5 prominent nerves, dorsal line pubescent to about $2 / 3$ of its length, thence glabrous; external face covered with acute papillae; collar $1 \mathrm{~mm}$ high, brownish purple, the edge with a crown of white hairs about I $\mathrm{mm}$ long, but shorter on the ventral side; awn to $70 \mathrm{~mm}$, slightly geniculate or almost straight, laxly twisted and pilose in the lower half, thence scabrous. Lodicules about $\mathrm{I}, \mathrm{r} \mathrm{mm}$, ovate-truncate. Palea nearly $2 \mathrm{~mm}$ long, ovate-lanceolate, acutate, nerveless. Stamens dimorphous, the anterior with normal anther, I $\mathrm{mm}$ long, linear, fertile, the others with more ovoid, $1 / 3-1 / 2 \mathrm{~mm}$ long, almost entirely sterile anthers. Anthers sometimes aristulate. Ovary about I mm long, fusiform, stigmas short pedicellate. Flowers cleistogamous.

This species was listed as S. manicata Desv. by PhILIPPI, Bot. Zeit. XIV.630, but distinguished as var. hirsuta on the label of GERMAIN's specimen in Herb. Santiago, collected Oct. 1854 in Masatierra. Later PHILIPPI, who collected the same species in Nov. I864, described it as S. fernandeziana Phil. A comparison with the type showed that all my material must be referred to PHILIPPI's species; his plants, however, differ from mine in the empty glumes reaching a length of $2 \mathrm{I} \mathrm{mm}$. while the awn is as much as $90 \mathrm{~mm}$ long.

It is not at all remarkable that PHILIPPI at first regarded the island Stipa as a variety of $S$. manicata. I have not seen authentic material of the latter, but to judge from the detailed description in GAV, Bot. VI.288, it must come very near this. S. manicata differs by the shorter leaves, which are hairy on the inside and glabrous on the outside, the longer ligule, the shorter glumes, described as green below, the shorter pedicel of the flower, shorter awn etc. The anthers seem to be alike in both.

As only one Stipa has been collected in the islands by all visitors known to me, it seems natural to identify $S$. Neesiana var. feinandeziana Trin. et Rupr. with S. fernandeziana Phil, but the description „foliis planiusculis cum nodis glabris ligula $\mathrm{I}^{1} / \mathbf{2}$-lineali» does not answer to any form seen by $m$ in the islands or in herbaria. My specimens of $S$. Neesiana from Central Chile (no. IOI7); determined by Prof. PILGER, are glabrous and have smaller spikelets than $S$. fernandeziana. Prof. PILGER was inclined to regard the latter as identical with

7-20sno. The Nat. Hist. of Juan Fernandez and Easter Isl. Vol. II. 
S. longiflora Steud Syn. I. I24, of which there is a sheet in Berlin (BERTERo no. 800). But the description of STEUDEL clearly forbids the identification. The leaves are $\mathrm{I} \mathrm{mm}$ wide only, the rays of the panicle bear $\mathrm{I}-3$ flowers, the glumes are 5 -nerved and only 6 to $8 \mathrm{~mm}$ long, the floscule» is described as pilose all over. I collected a Stipa near Valparaiso (no. IOI9), that answers very well to STEUDEL's description, and this is not S. fernandesiana. I have no reason to doubt that $S$. fernandeziana is the same as $S$. longiflora Herb. Berlin, for Steudel quotes BerTero no. 800 ex parte for his species. Prof. PILGER thinks that S. macrathera Phil. Anal. Univ. XCIII.720 is another nane for S. fernandeziana. The description is incomplete, and I have no authentic specimen at hand.

S. fernandeziana Stend. 1. c. was shown by Pilger ex SkotTsberg, Stud. 22 to be = Piptochaetium bicolor.

My identification of $S$. Skottsbergii Pilger 1. c. with S. fernandegiana Phil. was approved by the author of the former. There is a certain variation in the leaves, probably due to external conditions. The same kind of variation is found in Piptochaetium bicolor.

Area of distribution: Central Chile; Juan Fernandez.

\section{Piptochaetium Presl.}

2. P. bicolor (Vahl) Presl. - JoHOw, Estud. 125. - Syn. Oryzopsis bicolor Speg., SkotTsberg, Stud. 22; Stipa bicolor Vahl, non Johow nec HemsLey; S. fernandeziana Steud. non Phil.

Masatierra: Open ground in the centre of the island, not common. V. Colonial, near the colony (fl. $-\mathrm{fr} .5 / 12 \mathrm{I} 6$, no. I8) and also higher up (fr. ${ }^{24} / 12 \mathrm{I} 6$, no. I2OI); Pto Ingles (fr. ${ }^{19 / 1}$ I7, no. 315); grassy slopes of Villagra, ràther abundant (fr. $6 / 1$ I 7 , no. 243).

Area of distribution: South Brazil, Argentina, Chile, Masatierra.

3. P. laevissimum Phil. - JoHow, Estud. I35.

In the lower treeless parts of the valleys, abundant in the western half of Masatierra and in the basal region of Masafuera.

Masatierra: V. Colonial, east part, dry soil near the sea (fr. 11/12 I6, no. I IO); C. Salsipuedes, here and there up to about $600 \mathrm{~m}$; Pto Ingles, common (fr. $19 / 117$, no. 316 ); Q. Juanango, very common; between Villagra and Pta Larga, abundant, quite dominating over considerable areas (fr. $6 / 1 \mathrm{I} 7$, no. 240).

Masafuera: JoHOw. - Forming extensive mats in the basal region from Toltén to Vacas, south of this valley not so comimon. It covers the bottom of the outer part of the valleys, as well as the ridges between them, alternating with the forest patches (fr. $1 \% / 2$ I 7 , no. 553).

This grass was first found in Masatierra by PHILIPPI in 1864 and rediscovered in 1908 by the writer. It is, perhaps, the most common of all grasses considered to be indigenous.

Area of distribution: Central Chile (quoted by JoHow from the Cordillera of Santiago and Colchagua, collected by me near Valparaiso); Juan Fernandez. 


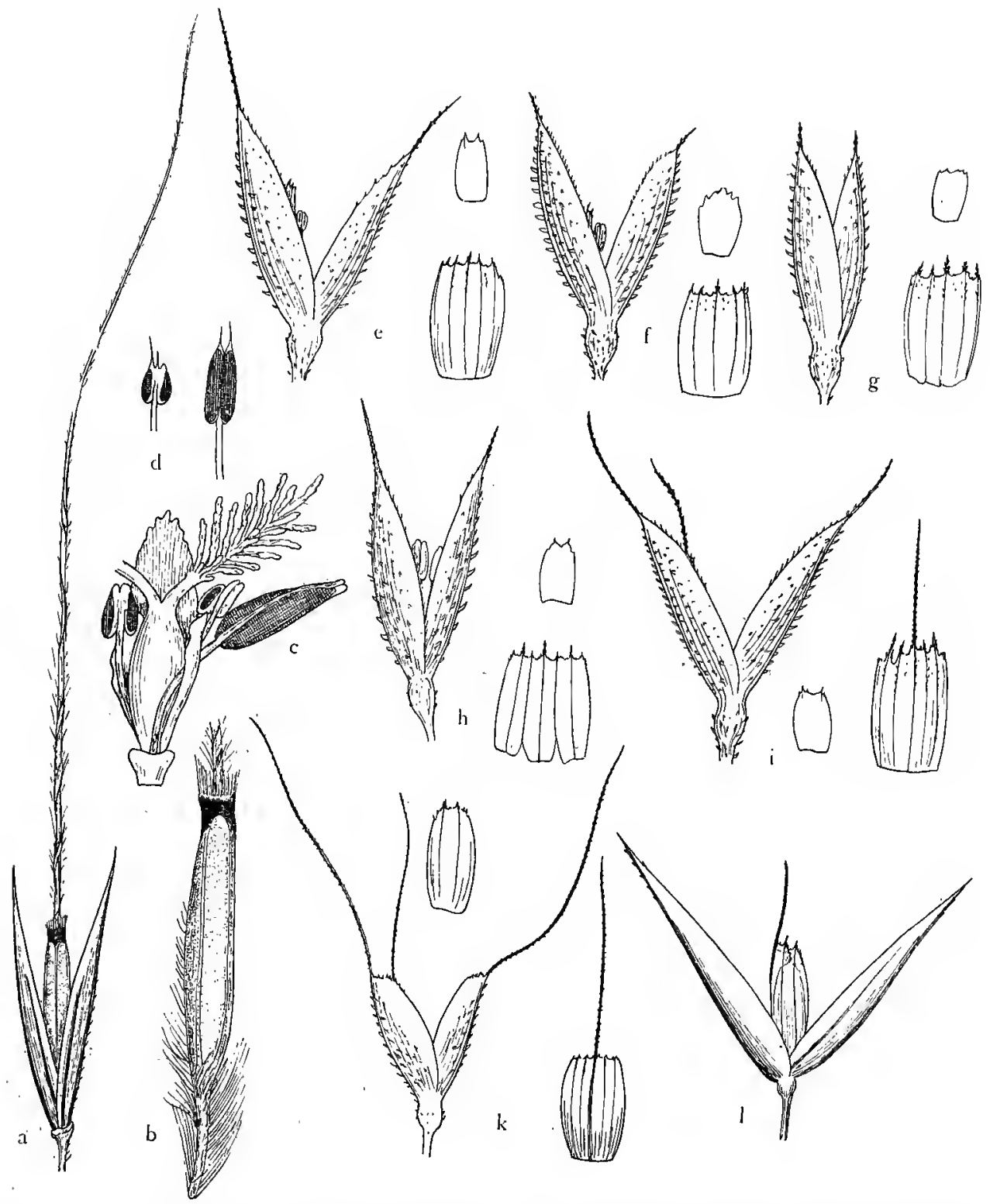

Fig. I. a-d Stipa fernandeziana: a spikelet, $\times 2 \frac{1}{2} ;$ b flowering glume, $\times 5$; c flower with palea and two lodicules, $\times$ 20; d anthers, $\times$ ro. e-i Polypogon imberbis, spikelets, flowering glume and palea: e leg. ReEd, f SkotTsberg no. 298, g no. 49I, h no. 47 I, i f. aristata no. ilog. k P. crinitus, spikelet, flowering glume and palea. 1 Agrostis masafuerana, spikelet. - e-1 X IO.

\section{Podophorus Phil.}

4. P. bromoides Phil. - JoHow, Estud. I35.

Masatierra: GERMAIN!

Discovered by Germain in the latter half of October, 1854. PhilipPI 
states (Bot. Zeit. XIV.649) that it is ofrequens in insula Juan Fernandez», but it has never been found a second time. All the material consists of the two sheets in Santiago and a third one in Kew. I need not tell that we made a careful search after this most interesting grass, but unfortunately without result. I must believe that it is a very rare plant. As it was in flower and fruit in October, it may have remained sterile during our permanence (Dec. I-April 30), and was perhaps confounded with Bromus (Megalachne). Still, every suspected grass tuft was examined.

Area of distribution: Monotypic and endemic in Masatierra.

\section{Polypogon Desf.}

5. P. imberbis (Phil.) Johow, Estud. I36. - Syn. Nowodworskya inberbis Phil. Anal. Univ. XLIII.562. - Fig. I e-i.

Masatierra: ReEd! (fig. I e). -- Dry soil near the sea, in the western section, rare; Pto Ingles (Philippil); B. del Padre (fl. $15 / 1$ I7, no. 298, fig. I f).

*Masafuera: near the sea in several places. B. Toltén (fl. $2 / 217$, no. 47 I, fig. I h); Tierras Blancas, not uncommon (fl.fr. ${ }^{17} / 2$ I7, no. 49I, fig. I g). New for Masafuera.

f. aristata n. f. A typo differt gluma florali longe aristata. Masafuera: Playa Ancha (fl.fr. ${ }^{12} / 3$ 17, no. I IO9, fig. 1 i).

A careful comparison with PHILIPPI's material in Herb. Santiago was made. The following notes may be added. Empty glumes $2,7-3 \mathrm{~mm}$ long, not counting the awn, the inner generally a little shorter, entire, very acute, scabrous on the back, awn terninal, $0,5-2 \mathrm{~mm}$ long; floral glume about $2 \mathrm{~mm}$ long, exaristate, sparingly scabrid on the back, 5-nerved witl 3 stronger and 2 weaker nerves, each prolonged into a scabrid point; palea about I $\mathrm{mm}$, hyaline, ovate, \pm truncate and generally 2-pointed.

Area of distribution: Endemic.

6. P. chilensis (Kunth) Pilger, Über einige Gram. 386. - Chaetotropis chilensis Kunth; JoHow, Estud. 136.

Masatierra: on open ground in some of the valleys, also in the dry western section. V. Colonial (begin. f. ${ }^{29} / 12$ I6, no. 206); Pto Ingles (f. ${ }^{19} / 117$, no. 3 I 7 ); Q. Juanango (fl. -fr. ${ }^{9} / 4$ I7, no. 605); Villagra, not uncommon (fl. ${ }^{5 / 1}$ I 7 , no. 239).

Area of distribution: Central provinces of Chile and Masatierra acc. to JoHow, but apparently also in other parts of South America, for PILGER quotes as synonyms Vilfa muricata Presl from Perú and Agrostis pectinata Hackel et Arechavaleta from Uruguay. It was perhaps introduced to Masatierra with the traffic of the I 8 th century.

\section{Agrostis L.}

7. A. masafuerana Pilger, Über einige Gram. 388. - Fig. I 1.

Masafuera: in the alpine fell-fields, very local; Las Torres, $1370 \mathrm{~m}$ (past ff. ${ }^{14} / 2$ I 7 , no. 424 ); C. del Barril, I $290 \mathrm{~m}$. - An addition to the magellanic element.

Area of distribution: Endemic in Masafuera. 


\section{Trisetum Pers.}

8. T. chromostachyum Desv. - JoHow, Estud. I37.

Masatierra: GERMAIN! REED! - In my previous paper on the islands I excluded this from the list of indigenous species. There are, however, , no special reasons to regard it as introduced. It must be rare, and we never found it.

Area of distribution: Central and South Chile; Masatierra.

\section{Danthonia DC.}

9. D. collina Phil. - JoIIow, Estud. I38. - Fig. 2 a.

Masatierra: PhILIPPi! - Dry rocky ridges and sunny arid slopes; the peak between Pangal and V. Colonial, $365 \mathrm{~m}$ (past fl. ${ }^{17} / 12$ 16, no. 148); Q. Damajuana (fl. $6 / 12$ I6, no. 52); C. Salsipuedes, dry, wind exposed rocks, not uncommon; Pto Ingles (fr. dispersed, $19 / 117$, no. 328); Villagra, frequent on the dry slopes (SKOTTSBERG Igo8; fl.fr. ${ }^{6} / 117$, no. 247 ).

First found by PHILIPPI and rediscovered (sterile) by the writer in Igo8. As there are so many American species of this genus I have thought it better to add a few figures for comparison.

Area of distribution: South Chile (Valdivia); Masatierra.

\section{Koeleria Pers.}

10. K. micrathera (Desv.) Griseb. Symb. Fl. Argent. 292. - Syn. Trisetum micratherum Desv. ex GAY, Bot. VI.352; T. laxum Phil. Anal. Univ. XLIII.568, JoHOW, Estud. 137; PILGER, Über einige Gram. 387. - Fig. 2 b-h.

Masaticrra: PhILIPPI! - Rocky places near Portezuelo de Villagra, in brushwood c. $590 \mathrm{~m}$, very scarce (f. ${ }^{10} / 1 \mathrm{I} 7$, no. 279).

I have not seen the type of Trisetum micratherum, to which T. laxum is referred on the authority of Prof. PILGER; according to the description the former has much shorter leaves (only $2-3$ inches), pubescent sheaths, outer glume $2 / 3$ as long as the inner, etc., but these differences disappear, it seems, at a closer look, for PILGER writes 1. c. 388: „Die Skottsbergschen Exemplare stimmen mit denen von Valdivia durchaus überein». If the plant from Argentina belongs here is an open question.

In his monograph of Koeleria, Bibl. Bot. 65, Domin calls K. micrathera a smixtum compositum». He had seen PhILIPpI's specimens from Valdivia and concludes that they must belong to some other genus. His reason for excluding it from Koeleria evidently is that, as it is perennial and caespitose, it belongs to the subgenus Airochloa, but all the Airochloas have much larger anthers. The annual Lophochloa species have smaller anthers. Thus, it takes an intermediate position. There is no other genus where we could find a suitable place for it, and a new genus could not very well be based only on the small size of the anthers. 
A short description of the insular plant will perhaps be welcome.

Densely caespitose but slender, dull green. Leaves to $30 \mathrm{~cm} \mathrm{long,} \mathrm{only}$ I,5-I,7 mm wide, plicate; sheath glabrous, blade nearly glabrous, with few, long and thin hairs; ligule almost wanting, transition between sheath and blade pilose. Culm with few leaves. Panicle 5-10 $\mathrm{cm}$ long, multiradiate, contracted; spikelets numerous, short pedicellate, with two complete flowers and a third, terminal, rudimentary one, pilose as the rhachis. Empty glumes acute, very unequal, lower c. $2 \mathrm{~mm}$ long, narrow lanceolate, I-nerved, upper about twice as long, broad lanceolate, 3-nerved, floral glume 5-6 $\mathrm{mm}$ long with broad hyaline margin, shortly bifid with oblique triangular lobes, 3 -nerved, with scabrid keel; awn subterminal, I-I,5 $\mathrm{mm}$; palea $3 \mathrm{~mm}$ long, oblanceolate, acutely bidentate, 2-keeled with scabrid keels. Anthers 0,5-0,75 $\mathrm{mm}$ long.

Area of distribution: South Chile (Valdivia); Masatierra.

\section{Bromus L.}

Megalachne, hitherto one of the monotypic insular genera, was reduced to Bromus by PILGer, Über einige Gram. 386. The long awns of the empty glumes give a quite characteristic appearance to Megalachne, but, as PILGER emphasizes, this character alone is not sufficient to separate the two genera. Hemsley, Chall. Rep. Bot. I: 3.63 found that Megalachne might be distinguished by the glabrous ovary and the three styles. But while the young ovary is glabrous or nearly so, older stages show rigid hairs covering its apex and surrounding the styles. And the new species, discovered by the writer, has two subapical styles, so that little can be advanced against PILGER's view. On the other hand, three styles are reported to occur in the section Ceratochloa. On account of the heavily awned empty glumes, Megalachne should be retained as a special section of Bromus.

I I. B. (Megalachne) feruandezianus (Phil.) Skottsb. - Syn. M. Berteroniana Steud. Syn. I. 237, JoHow, Estud. I40; Pantathera fernandeziana Phil. Bot. Zeit. XIV.649; B. megalachne Pilger 1. c. - Fig. 2 i.

Masatierra: Not uncommon in the eastern and central parts, along the ridges in the montane region, in open glades of the woods, among brushwood etc., hanging down from the rocks and forming quite ornamental patches. Pto Frances, Loma del Incienso, $360 \mathrm{~m}$, common; El Pangal, on the steep slopes from $250-300 \mathrm{~m}$, also in wet moss by the waterfall; in the gap between Damajuana and Yunque, $580 \mathrm{~m}$ (f. ${ }^{18} / 12$ I6, no. I 55); V. Colonial, C. Central, c. $570 \mathrm{~m}$; Q. del Monte Maderugo, steep wall, $390 \mathrm{~m}$; Portezuelo de Villagra, common on the ridges, $5-600 \mathrm{~m}$ (fl. ${ }^{3} / 12 \mathrm{I} 6$, no. 30); C. Salsipuedes, $400-600 \mathrm{~m}$, common; Q. Juanango, by the stream, $215 \mathrm{~m}$; B. Villagra, low hill near the camp, c. $200 \mathrm{~m}$.

Masafuera: in the same kind of places as in Masatierra, but less frequent. Q. de las Casas (JoHow), not uncommon on the walls of the gorge, (past $f$. $11 / 217$, no. 456); Q. de las Vacas (JoHow); Q. Angosta, at the waterfall; Q. del Varadero; $Q$. de la Lobería, along the stream in the forest, r7o m; Las Torres, wet moss mats on the rocks, I370 $\mathrm{m}$ (forma! past f. $14 / 2 \mathrm{I} 7$, no. 425 ); C. del 

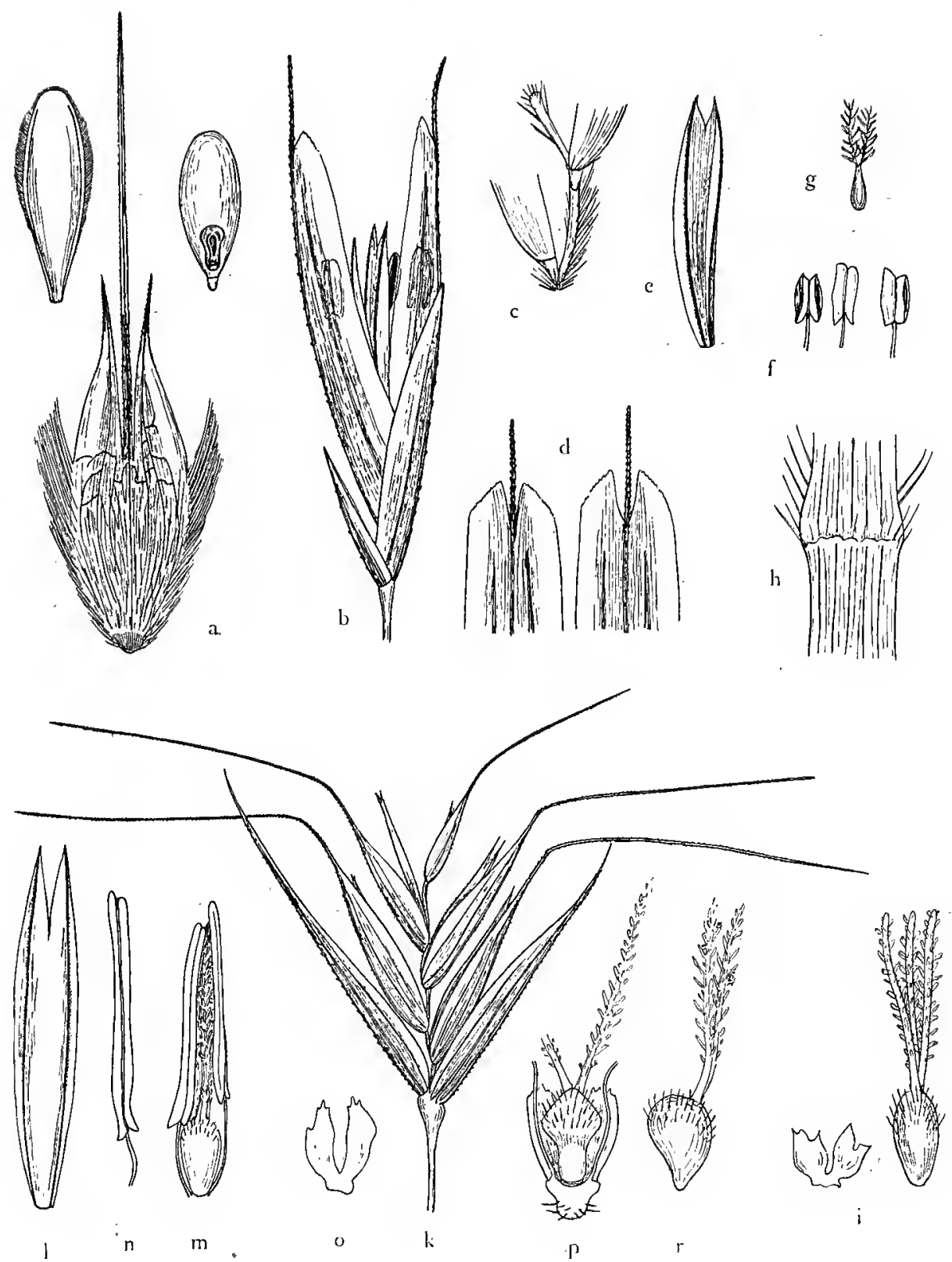

Fig. 2. a Danthonia collina, flowering glume with palea and caryopsis, $\times 5$. b-h Koeleria micrathera: b spikelet, c rhachis with rudimentary flower, d tips of two flowering glumes, e palea, $f$ anthers, $g$ pistil, all $\times$ Io, $h$ ligule, $\times 12 \frac{1}{2}$. i Bromus fernandezianus, pistil and lodicules, $X$ ro. $\mathbf{k}-\mathrm{r} B$. masafueranus: $\mathrm{k}$ spikelet, $\times 2 \frac{1}{2}, 1$ palea, $\mathrm{m}$ pollination, $\mathrm{n}$ anther, all $X 5$; o lodicules, ' $p$ flower, $r$ pistil from the side, all $\times$ ro.

Barril, $985 \mathrm{~m}$; lower slopes of Los Inocentes, open space in fern forest, c. $950 \mathrm{~m}$. - No. 425 differs from the ordinary form in having more scabrid glumes; the spikelets are unusually large, about 6 -flowered. 
PILGER made the new name $B$. megalachne in order to avoid confusion between $B$. Berteronianus and B. Berterianus Colla. But there is no reason why we should not use PHILIPPI's specific name.

Area of distribution: Endenic.

*12. B. (Megalachne) masafueranus Skottsb. et Pilger ex PILGER, Über einige Gram. 385 . - Fig. 2 k-r.

Masafuera: Las Torres, on rocks, I $370 \mathrm{~m}$ (fl.-fr. ${ }^{14} / 2$ I 7 , no. 4I 5).

An interesting addition to the flora. The description 1. c. is supplied here with some illustrations. The flowers are cleistogamous (see fig. $2 \mathrm{~m}$ ).

Area of distribution: Endemic in Masafuera.

\section{Chusquea Kunth.}

I3. Ch. fernandeziana Phil. - JoHow, Estud. I4I.

Masatierra: in the forest belt, rare below $400 \mathrm{~m}$, more common higher up, but never abundant nor forming thickets comparable with the famous chilean "colihuales"; also in dense brushwood on the high peaks and crests. - C. Chifladores, slope of the Frances Valley, c. $500 \mathrm{~m}$ (no. 62 I); main ridge above Pangal, $795 \mathrm{~m}$; north side of Damajuana, $530 \mathrm{~m}$ and in the quebrada below, west side, $345 \mathrm{~m}$ (no. 212); V. Anson, slopes of Co Yunque; Co Pirámide, on rock ledges, 550-600 m; V. Colonial, Q. Gutierrez, c. $450 \mathrm{~m}$, in dense forest; Pto Ingles, in higher ground; Co Alto (P. GUTIERREz); mountain spur west of Co Yunque, 4I5 m; Q. Villagra, just below Portezuelo, and by the stream farther down, I60 $\mathrm{m} ; \mathrm{Q}$. de la Choza, c. $300 \mathrm{~m}$, not uncommon.

The colihue did not flower during our permanence, nor was it fertile in 1908. Flowers are known from the type material only (coll. Nov. I864, PHILIPpi!)

Area of distribution: Endemic in Masatierra.

\section{Cyperaceae.}

\section{Cyperus L.}

14. C. vegetus Willd. - JoHow, Estud. I42.

Moist places, generally near the sea.

Masatierra, only reported from the central and western sections: El Pangal (JoHow); V. Colonial (past fl. ${ }^{29} / 12$ I6, no. 202); Pto Ingles, by the stream near the sea; B. Chupones.

Masafuera: Germain. - Rocky coast between Casas and Vacas (fl.-fr. 13/2 I7, no. 426); near Las Chozas; Lobería vieja, on the beach.

Area of distribution: Chile; Juan Fernandez; Easter Island.

I 5. C. reflexus Vahl. - JoHOW, Estud. I42.

Masatierra: reported by Scouler, Bertero, Germain, Reed, Moseley and JoHow, by the last mentioned from B. Cumberland. We did not see it. 
Johow united $C$. fernandezianus Colla with $C$. reflexus. Clarke retained it as a species under Pycreus, because the stigma was described as bifid, but he had not seen specimens. It is a very dubious species.

Area of distribution: Mexico and Texas to extratropical South America; Chile; Masatierra.

\section{Scirpus L.}

I6. S. nodosus Rottb. - JoHow, Estud. I42.

Masatierra: In some places near the sea, but more often seen on open, devastated ground or on the high ridges, always local and only collected before by Philippi, Moseley and the writer (1908). - El Pangal, west branch, on barren slopes; V. Colonial, near the road to Portezuelo, $325 \mathrm{~m}$; C. Salsipuedes, edge of the forest $\mathrm{c}$. $600 \mathrm{~m}$ (fl. ${ }^{20} / 12 \mathrm{I}$, no. I74); Pto Ingles, on the beach and on the central ridge; $Q$. Juanango; $Q$. Villagra, not uncommon (past $f .{ }^{5} / 1$ I 7 , no. 238), and westward to B. Chupones.

Masafuera: Cuming! Johow. - Abundant along the east coast from Toltén to Playa Ancha (past fl. Feb. I9I7, no. 513).

Area of distribution: Widely dispersed in the south temperate zone, circumpolar.

17. S. cernuus Vahl. - Skottsberg, Stud. 23.

Masatierra: Wet places along the coast, first found be the writer in B. del Padre, I908, - Outer part of El Pangal, mats in the stream (fl. ${ }^{11} / 12 \mathrm{I} 6$, no. $9^{8}$ ) and at the waterfall in the bottom of the gorge (fl. $-\mathrm{fr} .1 / 1 \mathrm{I} 7$, no. 222); B. Cumberland, wet grassy swamps near the sea (fl.-fr. ${ }^{11} / 1216$, no. 99 , fr. ${ }^{29} / 1216$, no. II7I); Q. Juanango, in the stream; B. del Padre, on the beach; outlet of a small stream near the foot of Co Negro; small stream west of El Yunque; B. Chupones, dry stream bed.

*Masafuera: $Q$. de la Lobería (fl.fr. ${ }^{17} / 2$ I7, no. 522). - New for Masafuera.

Very variable in size; no. 222 reaches a length of $40 \mathrm{~cm}$, probably the largest form ever recorded (»culmi 3-18 cm" acc. to CLARKE, Cyper. chil. 28).

Area of distribution: Subcosmopolitan.

\section{Heleocharis R. Br.}

I8. H. maculosa (Vahl) R. Br. subsp. fuscopurpurea (Steud.) Kükenth. Cyp. Nov. V. 432. - Syn. Isolepis fuscopurpurea Steud., H. vincentina Clarke 1. c.; H. melanocephala, JoHOW, Estud. I43? - Fig. 3 a.

Masatierra: B. Cumberland, grassy swamp along a small stream (fl.-fr. $11 / 12$ 16, no. 97).

I think REED's specimens, cited under $H$. melanocephala by JoHOw, belong here. Clarke quotes PHILIPPI no. $5 \mathrm{I}$ for Juan Fernandez, but PHILIPPI is not listed as collector by JOHOW, and CLARKE quotes the same number for specimens from Talca in Chile. 
var. irritans Kükenth. 1. c.

Masatierra, outlet of a small stream near the foot of Co Negro, abundant (fl.-fr. $7 / 1$ I 7 , no. 231 ).

Larger, with light yellowish brown spikes. I dare say this is what JoHow 1. c. calls $H$. maculosa, first found by REED and later by JoHow in B. del Padre, where I have sought for it in vain.

Area of distribution: Subsp. fuscopurpurea is known from South Chile and Masatierra, but $H$. maculosa is quoted for the Antilles, Brazil and Chile.

\section{Oreobolus R. Br.}

*ig. O. obtusangulus Gaud.

Masafuera: Los Inocentes, forming large compact cushions, $1375-1500 \mathrm{~m}$ (fr. ${ }^{22} / 3$ I 7 , no. 384). - An important addition to the magellanic element.

Area of distribution: Andes of New Granada and Ecuador to Cape Horn; Falkland Islands; Masafuera.

Cladium P. Br.

20. C. scirpoideum (Steud.) Benth. et Hook. f. - JoHow, Estud. I43.

Masatierra: Streams, waterfalls and other moist places in the forest belt, not at all so rare as indicated by JoHow, but found in many places in the central parts of the island. - El Pangal, by the waterfall, c. $200 \mathrm{~m}$ (fl. $1 / 1 \mathrm{r} 7$, no. 224; also JoHow); north-east precipice of Co Damajuana, $500-550 \mathrm{~m}$; the gap between Damajuana and Yunque, abundant on wet rocks, c. $600 \mathrm{~m}$ ( $\mathrm{f}$. 18/12 I6, no. I63); Plazoleta del Yunque (JoHOW); Portezuelo de Vilagra, one specimen just behind the Selkirk tablet, with Gunnera bracteata (past. fl. ${ }^{81} / 1$ I 7 , no. 359); C. Salsipuedes, edge of the forest, rare, $630 \mathrm{~m}$ (past fl. $8 / 1216$, no. 72); Pto Ingles, central ridge, c. $470 \mathrm{~m}$; Q. Juanango, at the brook, $215 \mathrm{~m}$ (fl.-past f. $9 / 417$, no. 602 ); $Q$. Villagra, wet rocks in the stream, $240 \mathrm{~m}, 160 \mathrm{~m}$; $Q$. de la Choza, wet rock in the forest, c. $400 \mathrm{~m}$.

According to KÜKENTHAL, in letter to the writer, this species is nearest related to $C$. angustifolium (Gaud.) Benth. et Hook. f. from Hawaii and Tahiti.

Area of distribution: Endemic in Masatierra.

\section{Uncinia Pers.}

*2I. U. brevicaulis Thouars.

Masafuera: Alpine fell.fields in the northern half of the highland; the Correspondencia Camp, II $30 \mathrm{~m}(5 / 3 \mathrm{I} 7$, no. $269 \mathrm{~b})$, and a few hundred $\mathrm{m}$ north of this place $\left({ }^{25} / 2 \mathrm{I} 7\right.$, no. $\left.369 \mathrm{c}\right)$; Las Torres, on rocks, $1370 \mathrm{~m}(14 / 217$, no. 369). Everywhere with unripe achenes. - Another addition to the magellanic element. 
Area of distribution: South Chile, Valdivia to West Patagonia and Fuegia; Masafuera; Andine Patagonia (very rare); Falkland Islands; Tristan da Cunha; St. Paul's and Amsterdam Islands.

22. U. Douglasii Boott. - JoHow, Estud. I44.

Masatierra: Common in the forest belt, in all the valleys from Pto Frances to $Q$. Juanango, but rarely seen below $200 \mathrm{~m}$; also on the south side of the island; in dense forests or in open glades (fl.fr. Dec. 1916, nos. 47, 56,189 ).

Masafuera: Common in the forest patches and in the damp gorges, 200 $-500 \mathrm{~m}$, from $Q$. Sanchez to $Q$. de la Lobería (unripe fr. Feb. 1917, nos. $463,487)$.

Area of distribution: Endemic.

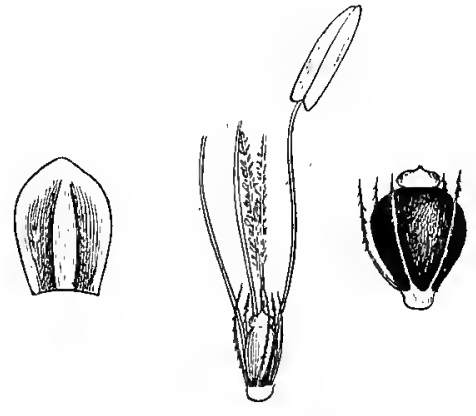

a

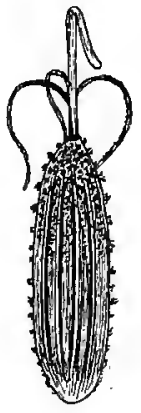

Fig. 3. a Heleocharis fuscopurpurea, bract, $\times 6$, flower and fruit, $X$ I 2. b Uncinia costata, utricle, bract and pistil, $\times 6$.

*23. U. costata Kükenth. Cyp. nov. V. 433. - Fig. 3 b.

Masafuera: $Q$. Loberia, stony ground in forest, $280 \mathrm{~m}$, with the preceding.

A very distinct species, well separated from $U$. Douglasiz, to which it is related.

Area of distribution: Endemic in Masafuera.

*24. U. phleoides Pers.

Masafuera: in the fern beds at the Correspondencia Camp, I $30 \mathrm{~m}$, rare (fr. ${ }^{25} / 2,5 / 317$, no. 370). - New for Juan Fernandez.

Dr. KÜKENTHAL brought my specimens to var. nux nigra C. B. Clarke; this is not a very distinct variety, and part of my material might equally well be classed with the typical form.

Area of distribution: The Andes from Columbia to Patagonia; Chile; Masafuera.

*25. U. tenuis Poepp. f. firmula Kükenth. Cyp. nov. V. 433.

Masafuera: In the alpine fell fields, probably not uncommon. - Las Torres, $1370 \mathrm{~m}$ (fr. disp. ${ }^{14} / 2.17$, no. I 173); C. del Barril, 925-1290 m (fr. ${ }^{1 / 3} 17$, 
no: 56I); Los Inocentes, on the summit, c. I $500 \mathrm{~m}\left(\mathrm{fr} .{ }^{9} / \mathbf{3} 17\right.$, no. 382 ) and on lower slopes, $900 \mathrm{~m}$ (fr. ${ }^{22} / 2$ 17, no. I172). - New for Juan Fernandez.

Area of distribution: Costa Rica; Masafuera; South Chilean Andes to Cape Horn; the new form only on Masafuera.

\section{Carex L.}

*26. C. Banksii Boott.

Masafuera: Alpine fell-fields near Las Torres, $1350-1370 \mathrm{~m}$ (fr. ${ }^{14 / 2} 17$, no. 393). - New for Juan Fernandez.

Area of distribution: Andes of Santiago; Mendoza; South Chile to Fuegia.

27. C. Berteroniana Steud. - Syn. C. paleata Boott; JoHow, Estud. 144.

Masatierra, in the eastern half of the island, not uncommon in the forest belt; Pto Frances (JoHow), Loma del Incienso, in brushwood, $360 \mathrm{~m}$; C. Centinela, forest patch, c. $300 \mathrm{~m}$; El Pangal, near the waterfall, $200 \mathrm{~m}$; Portezuelo de Villagra, scattered along the ridges (JoHow; fl.fr. Dec. I9I6, nos. 5, 37); C. Salsipuedes, in thickets (fr. ${ }^{3} / 12 \mathrm{I} 6$, no. 85 ); Q. Juanango, edge of forest; Q. Villagra (A. ${ }^{8} / 1$ I7, no. $37 \mathrm{~b}$ ). - Variable in size: 37 and $37 \mathrm{~b}$ are slender forms, 5 and 85 very large ones with unusually large female spikes.

Masafuera: GERMAIN! - Q. de las Casas, not uncommon in the canyon (fr. ${ }^{\mathrm{I} 1} / 2$ I7, no. 453 ); $Q$. del Blindado, $440 \mathrm{~m}$ in the forest; $Q$. Angosta; $Q$. de la Lobería, open forest, $280 \mathrm{~m}$.

Area of distribution: Endemic.

\section{Palmae.}

\section{Juania Drude.}

28. J. australis (Mart.) Drude. - JoHow, Estud. I45. - Fig. 4.

Masatierra: Through the whole of the forested region, not seen by us at a lower altitude than $190 \mathrm{~m}$ but reaching the highest crests. As was stated

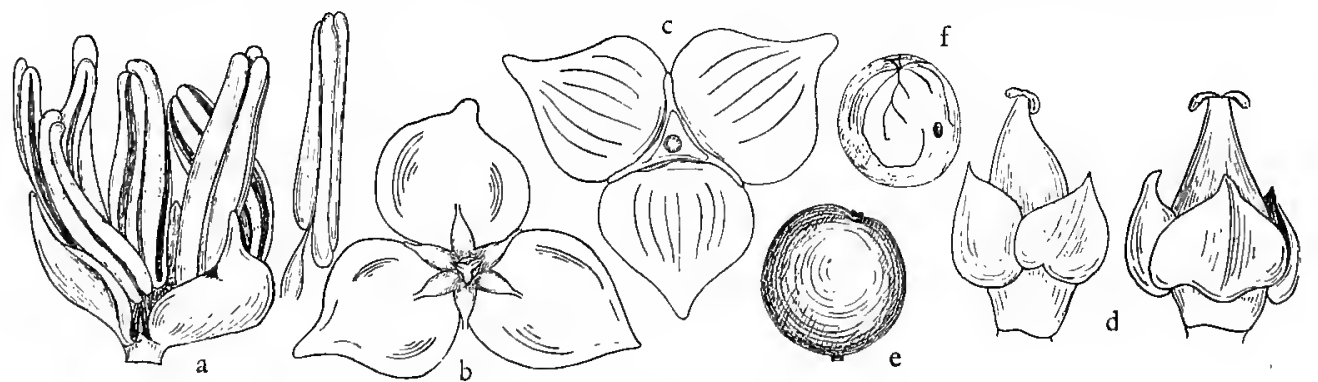

Fig. 4. Juania australis: a $\sigma$ fl. and one stamen, b inside of same, anthers removed, c outside of same, d $Q \mathrm{fl}$, all $\times 4$; e truit, $1 / \mathrm{s}$ nat. size; $\mathrm{f}$ seed, $\times 11 / \overline{0}$.

by JoHow, Fuania is not at all on the verge of extinction, but it is true that it has become very rare in places of easy access. So great is the interest taken in this palm that I find it worth while to enumerate the localities where 
it was observed by us: Pto Frances, c. $360 \mathrm{~m}$, several trees, c. $500 \mathrm{~m}$, rather common; C. Chifladores, on the ridge; ridge between $Q$. de la Piedra Agujereada and Q. Laura, 600-650 m, numerous trees; C. Centinela, not uncommon; in the depression between Damajuana and Yunque, c. $600 \mathrm{~m}$, some trees; Q. Damajuana, c. $250 \mathrm{~m}$, rare; slopes of El Yunque; V. Colonial, Q. Gutierrez, c. $300 \mathrm{~m}$, one tree (no. 50); $Q$. del Monte Maderugo, rare; $Q$. Seca, $435 \mathrm{~m}$, one tree; northwest slope of Co Pirámide, $600 \mathrm{~m}$, a few trees; on the inaccessible crests round Portezuelo, $600-650 \mathrm{~m}$, many groups; C. Salsipuedes, solitary specimens $600-650 \mathrm{~m}$; Pto Ingles, west quebrada, several groups from I $90 \mathrm{~m}$ and upwards (fl.fr. ${ }^{2 \%} / 1$ 17, no. $310 \delta, 314 \%$ ); south side of the island, high cliffs east of Yunque, scattered in the altitude of $7-800 \mathrm{~m}$ (fr. March 1917); B. Villagra, Q. de la Choza, 3-400 $\mathrm{m}$, numerous trees.

DRUDE placed Fuania in the subtribe Iriarteae, but the male flowers, first found by JoHow, are symmetrical and the stigma almost apical. It comes nearer to Morenieae, but it differs from both in being strictly dioecious. It seems better to make it the type of a separate subtribe.

Area of distribution: Endemic in Masatierra; monotypic.

\section{Bromeliaceae.}

\section{Greigia Regel.}

29. G. Berteroi nov. spec. - Syn. Tillandsia spec., Bertero in Ann. sc. nat. XXI.348.

Truncus lignosus inferne longe repens nec non radicans, dein curvatoadscendens et erectus, ad metrum et ultra longus, circ. $3 \mathrm{~cm}$ crassus, vaginis foliorum castaneis dense vestitus, apice rosulam sat magnam foliorum gerens. Folia linearia, membranacea, $75-90 \mathrm{~cm}$ longa, basi in vaginam ad $25 \mathrm{~mm}$ latam sensim dilatata, supra basin IO-I $2 \mathrm{~mm}$ láta, dein sensim latiora, medio ad $18 \mathrm{~mm}$ lata, dein sensim angustata, acutissima, longissime aculeata et apice debiliter pungentia, margine a basi ad $3 / 4$ long. inermia, versus apicem aculeis unguiformibus minutis circ. $1 / 2 \mathrm{~mm}$ longis parce munita, supra glaberrima, laete viridi-lactea, subtus argenteo-paleacea. Cetera ignota.

Masatierra: Bertero! - Gorge above Pangal, c. $660 \mathrm{~m}$, on humid soil in dark Dicksonia-forest; one specimen growing on a fallen trunk. According to some of the islanders, the same plant has been observed on the high crest south of Pto Ingles.

After a diligent search in many places, we rediscovered this extremely rare plant in a very remote corner. Unfortunately, none of the few specimens observed were fertile, nor did they show any sign of ever having produced flowers. Possibly the inflorescence is terminal, and the plant attains a great age before it flowers. The stem is simple, or perhaps branched at an early date, the branches becoming separated. The shoot is perhaps monocarpic.

On BerTERo's specimen in Kew is written: "Folia maxime similia Gregia Pearcei Mez, vide Bromel: 47", very likely written by MEZ, who quotes the Kew specimen. The vagina is broader in $G$. Berteroi, and it differs from other 
species in its caulescent habit; it is of the same morphological type as the rosulate dwarf trees of which there are so many in these islands.

In spite of being unable to give a full description of this peculiar plant, I have thought it better to give it a name: it is certainly not identical with any other, and I do not think it will have to be transferred to another genus, if not to a new one.

Area of distribution: Endemic in Masatierra.

\section{Ochagavia Phil.}

30. O. elegans Phil. - JoHOw, Estud. I 49. - Fig. 5 a.

Masatierra: On rocky ridges from near sea level to the highest crests, not seldom covering the steep cliffs in warm, sunny situations. Pto Frances

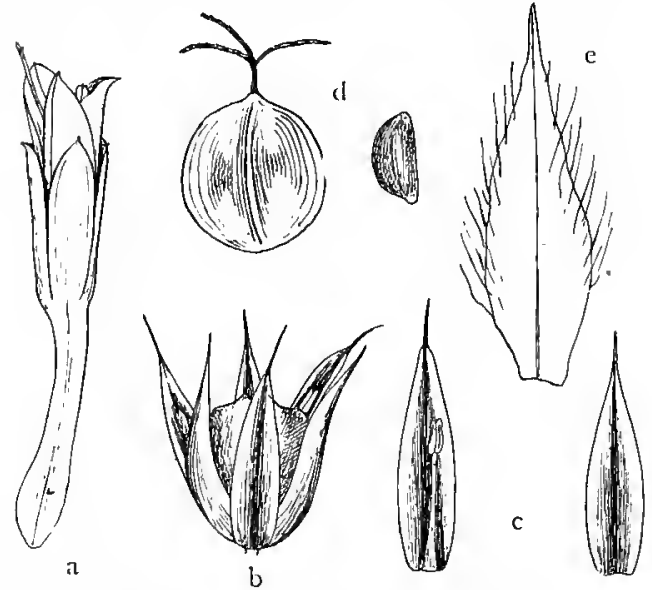

Fig. 5. a Ochagavia elegans, flower, nat. size. $\mathrm{b}-\mathrm{e}$ Luzula *insularis; $\mathrm{b}$ flower in fruit, c outer (with stamen) and inner tepal, d capsule and seed, c bract, all $\times 10$.

(JoHOw); El Pangal, on the walls of the canyon, c. $200 \mathrm{~m}$; between Pangal and V. Anson, slope near the sea, c. $50 \mathrm{~m}$ (a form with longer leaves); the Damajuana ridge, c. $500 \mathrm{~m}$; between Damajuana and Yunque, $580 \mathrm{~m}$; Co Pirámide, 550-650 m, abundant in places (fl. Dec. I9I6, no. 21); V. Colonial, Q. del Monte Maderugo, steep rocks, $390 \mathrm{~m}$; C. Salsipuedes, $465 \mathrm{~m}$, large patch; ridge between Vaquería and Juanango, c. $300 \mathrm{~m}$; Morro Juanango (JoHOw), abundant; north slope of Co Tres Puntas, very abundant (also JoHow).

MEZ, DC. Monogr. Phanerog. IX.366, reduced Ochagavia to Rhodo. stachys. It is a matter of taste if we follow him or not. Ochagavia was described in Bot. Zeitung 1856 , Rhodostachys in Linnaea 1857 ; the difference between them is slight, the epigynous tube being more than twice as long in the former, reaching a length of $12-15 \mathrm{~mm}$. The stem is much more elongated, clothed with leaves, the stamens shorter or as long as the petals, which are of a deep violet-crimson. The inflorescence is a short compact spike.

Area of distribution: Endemic in Masatierra; monotypic.

\section{Juncaceae.}

\section{Luzula DC.}

3I. L. racemosa Desv. (sp. coll.) subsp. insularis nov. subsp. - Syn. L. cfr. alopecurus, Skotrsberg, Stud. 24. - Fig. 5 b-e.

Dense caespitosa, ad $50 \mathrm{~cm}$ alta, erecta robusta. Folia ad $15 \mathrm{~cm}$ longa, 
plana, plerumque 5-8 mm lata, margine dense ac longissine albo villosa, apice acuta subpungentia. Inflorescentia erecta, adulta subnutans, ovoidea-cylindrica, sat compacta, foliis $2-3$ sat longis et latis instructa, interdum spicula infima remota et longius pedunculata; spiculae compositae ovoideo-cylindricae vel conicae, bracteis bracteolisque pallidis subhyalinis longe ciliatis. Flores ad $3 \mathrm{~mm}$ longi, tepalis integris, externis ovato-lanceolatis, \pm convolutis, apice manifeste aristato-acuminatis, $2,8-3 \mathrm{~mm}$ longis, castaneis margine pallido, internis $2,5-2,6 \mathrm{~mm}$ longis acute acuminatis. Stamina 3 perigonio multo breviora, antherae oblongae $0,4-0,5 \mathrm{~mm}$, filamentis duplo breviores. Stylus brevis, $0_{3} \mathrm{~mm}$ longus, stigmata longa. Capsula nigro-castanea, trigono-sphaeroidea, apiculata, perigonio multo brevior. Semina minuta oblique fusiformia, ferruginea, basi et apice luteola, $0,8-1 \mathrm{~mm}$ longa.

Masafuera: In the alpine region, rate, - The high ridges north of the Casas valley, from $1000 \mathrm{~m}$ upwards; more common at Las Torres, I350-1370 m (fr. ${ }^{14} / 2-20 / 2$ I7, no. 408 ); west wall of the island; C. del Barril, I $290 \mathrm{~m}$.

$L$. racemosa was established on specinens from the high volcanic peaks of Mexico, collected by Humbold and by Schiede, see Kunth Enum. PI. III.3 I 3. L. vulcanica Liebm., of which I have seen authentic material (Herb: Upsal.) seems to be the same and was also referred to L. racemosa by BucHENAU. These plants agree very well with the description; so I conclude that the Mexican species is the true racemosa. Kunth did not know this from Perú or Chile, nor was it included in GAY's Bot. VI. BuchenaU, in Pflanzenreich, Juncac. 75 gave as area of distribution Mexico-Chile, and there are specimens from Fuegia in Herb. Upsal. under the name of L. racemosa, determined by him.

The position assigned to the insular form is entirely provisional. I am sure it has little or nothing to do with the Mexican plant, which has very narrow leaves, a slender, almost filiform culm, long ciliated tepals, very short stamens (less than half the length of the perigone) and a light brown capsule with very thin, papyraceous walls. If we had only the Mexican plant to consider, the form from Masafuera would never have been classed as a subspecies of $L$. racemosa. But according to BUCHENAU this is also a Chilean plant, occurring in several forms down to Fuegia, all, however, unlike the Mexican one in habit. Many authors and collectors liave followed BuCHENAU in bringing specimens from the southern Andes to $L$. racemosa. In I908 I collected such forms in West Patagonia and in Skyring Water. $L$. *insularis differs from them as well as from all other forms from the continent, that I have seen, in the broader leaves, the more compact panicle, the longer tepals etc. On the other hand, the forms of Chilean racemosa differ from each other in several respects, such as the length of the filaments and size of the anthers, which are twice as large in the form from West Patagonia as in the Skyring plant. Again, one plant collected in Fuegia by DUSÉN (no. 584) and determined by BUCHENAU has the tepals hardly longer than the capsule, thus recalling $L$. chilensis. I have not seen authentic material of the latter species. It differs from $L$. racemosa in possessing 6 stamens, larger anthers (as long as the filaments), and larger seeds ( $\mathrm{I}-2 \mathrm{~mm}$ ).

It is probable that the Chilean $L$. racemosa differs from the Mexican; it is evident that it includes more than one subspecies or species. When bringing 
the island type to this, I have followed BUCHENAU, for it has 3 stamens and a long perigone. I cannot undertake to revise the whole group, for which very extensive material is necessary; I can only express the opinion that, when a revision is made, $L$. racemosa in BuCHENAU's sense will not stand.

Area of distribution: Typical form only in Mexico; other forms (or species?) along the Andes to Fuegia; Masafuera.

\section{Juncus L.}

32. J. imbricatus Laharpe. - Syn. F. Chamissonis, JoHow, Estud. 151.

Masatierra: V. Colonial (JoHow), grassy slopes near the sea (fr. ${ }^{11 / 12} \mathrm{I} 6$, no. I08; ${ }^{17} / 12$ I6, no. $\left.108 \mathrm{~b}\right)$; B. Villagra; B. Chupones, stony ground (fr. $6 / 117$, no. 245 ).

The specimens correspond to var. Chamissonis (Kth) Buch., which is hardly separable even as a variety, as ill-defined transitions occur. The flowers show the size of the typical species, as described by Buchenau. The habit is variable; no. 108 has culms $15-25 \mathrm{~cm}$ high and a dense inflorescence, no. $108 \mathrm{~b}$ reaches a hight of $55 \mathrm{~cm}$ and has a rather lax inflorescence.

Area of distribution: Ecuador to South Chile; Masatierra; Argentina; Uruguay.

\section{*33. J. capillaceus Lam.}

Masatierra: East side of V. Colonial, swampy ground near the sea (fl.-fr. 29/12 I6, no. 20I): - Perhaps a recent introduction and not truly indigenous.

Area of distribution: Ecuador; Central Chile; Masatierra; Argentina; Uruguay.

\section{J. acutus L. - JoHow, Estud. I50.}

Masatierra: Scouler! - Pto Ingles, central ridge (fl. $2 \% 1 \mathrm{I} 7$, no. $3 \mathrm{I} 2$; f. laxior, no. 3I 2 b); La Vaquería, open ground (fr. $9 / 4$ I 7 , no. 598 ); stream west of Co Yunque; B. Chupones, on a slope covered with Rumex acetosella.

JoHOw believed that this species had been accidentally introduced and that it disappeared from the island soon after, as nobody except SCOULER had seen it. As we have seen, it is distributed over a large part of the island, and nothing enforces us to suppose that it came there with the human traffic.

Area of distribution: West and South Europe; Atlantic Islands; North Africa; the Cape; California; Central Chile; Masatierra; South Brazil; Uruguay; Argentina.

35. J. Dombeyanus Gay. - Johow, Estud. I51. - Syn. F.fernandezianus Steud. Syn. plant. glum. II. 302.

Masatierra: Germain! Philippi! - B. Tierras Amarillas, rare (fl.-fr. 5/1 I7, no. 242). - Belongs to a typicus Buch.

According to JoHow, $\mathcal{F}$. microcephalus Kunth is also found, coll. by Scouler, Douglas, Bertero, Reed and Moseley, but he had only seen REED's specimens, so that I suppose he followed HEMSLEY in bringing all to 
microcephalus. HEMSLEY was of the opinion that this hardly differs from Dombeyanus. The main difference lies in the size of the head. FuEntes, Revis. Fl. Chil. Junc. 27 speaks of transitional forms between the two among the material from Juan Fernandez. I do not think typical microcephalus has been collected in the islands.

Area of distribution: Perú; Chile; Masatierra; Uruguay.

*36. J. planifolius $\mathrm{R} . \mathrm{Br}$.

Masatierra: V. Colonial, small stream at the foot of the chapel hill (past fl. $22 / 12$ 16, no. 185 ).

Probably of recent introduction, perhaps with water-birds occasionally visiting Juan Fernandez; belongs to genuinus Buch., a broad-leaved form of this with sheath to $\mathrm{I} 2$ and blade to $9 \mathrm{~mm}$ wide.

Area of distribution: Australia; Tasmania; New Zealand; South Chile; Masatierra.

Iridaceae.

\section{Libertia Spreng.}

37. L. formosa Grah. - Syn.: var. grandiflora (Phil.), JoHow, Estud. I 50.

Masatierra: barren slopes and rocky ridges, not uncommon. - Co Damajuana, on the north side, c. $500 \mathrm{~m}$; V. Colonial, common from $200 \mathrm{~m}$ to Portezuelo (beg. fl. ${ }^{3} / 12$ 16, no. I3), more local at a lower altitude; C. Central, c. $570 \mathrm{~m}$; Q. Seca, c. $400 \mathrm{~m}$; C. Salsipuedes, frequent; Villagra; B. Chupones.

Masafuera: on the cliffs near the sea and also in the canyons, common; here and there in the alpine region. - Q. del Pasto; Q. de las Casas; $Q$. del las Vacas (fr. ${ }^{13} / 2$ I7, no. 427); Q. Angosta; Q. del Varadero; Tierras Blancas; Q. de la Lobería (also in the open forest); scattered in the highlands; greatest altitude observed, c. $1400 \mathrm{~m}$.

PHILIPPI argued that his L. grandiflora differed from formosa in the denser fascicles and the much larger flowers, and in the not cordate or retuse petals. I cannot find any difference between them. The flowers of the island plant are about $22 \mathrm{~mm}$ across, the sepals $8 \mathrm{~mm}$ long, the petals $16,5 \times 14 \mathrm{~mm}$, but smaller in many cases, the filaments $8-8,6 \mathrm{~mm}$, their tube about $2,5 \mathrm{~mm}$ long, the anthers $3 \mathrm{~mm}$. In most cases I found the petals distinctly emarginate and with a broad rounded, sometimes subcordate base. Plants grown from seeds, collected in the islands, have smaller flowers than the largest wild ones, but are otherwise quite typical.

$L$. formosa is very near $L$. elegans Poepp. Cultivated specimens of the latter flowered at the same time in the Gothenburg Garden; the most notable difference lies in the sepals, which are white, almost translucent at the base and crowned by a long, convolute, brown apex, while they are green, more or less pale at the base, obtusate and without acumen in $L$. formosa. The petals are not emarginate in elegans, the filaments measure 10 and the anthers $4 \mathrm{~mm}$. The pollen is dark yellow in this, but sulphureous in formosa.

Area of distribution: South Chile; Juan Fernandez.

8- 20s00. The Nat. Hist. of Juan Fernandez and Easter Isl. Vol. II. 
Piperaceae.

Peperomia Ruiz et Pavon.

38. P. Berteroana Miq. - Johow, Estud. 12 I.

Masatierra: Moist, shady woods, more numerous in altitudes above $300 \mathrm{~m}$. North slope of Co Damajuana, c. $500 \mathrm{~m}$; V. Colonial, C. Central, c. $500 \mathrm{~m}$; Portezuelo de Villagra (JоHOW), on the rocks near the pass and in the woods on both sides (fl. Dec. I9I6, no. 38); Q. del Monte Maderugo, rocks in the forest, $390 \mathrm{~m}$; Q. Salsipuedes, Dicksonia-forest, c. $650 \mathrm{~m}$ (fl.-fr. ${ }^{8} / 12$ I6, no. 96); Pto Ingles (JoHOw), central ridge, c. $380 \mathrm{~m}$ (fl. -fr. ${ }^{20} / \mathrm{r} \mathrm{I} 7$, no. $32 \mathrm{I}$ ); Q. Juanango, at the foot of the high waterfall; mountain ridge west of Co Yunque, c. $500 \mathrm{~m}$ (fl. ${ }^{24} / 4$ I7, no. 628); Q. Villagra, low hill near the camp, c. $200 \mathrm{~m}$ (f. hirsuta, no. 26I); Q. de la Choza, wet rock in the forest, c. $400 \mathrm{~m}$.

Masafuera: $Q$. de las Vacas (no. 394, also JoHow); Q. Angosta, in the gorge by a waterfall; $Q$. del Varadero; $Q$. de la Lobería. - Specimens from this island, all found on rock ledges in the canyons, are small and have smaller, less obovate, almost rhomboidal leaves. My material is sterile, and I do not know if the differences are of systematic importance.

Area of distribution: Endemic.

39. P. margaritifera Bert. ex Hook. Icon. Plant. I, t. 91. - JoHow, Estud. I22.

Masatierra: Bertero! Germain! - El Pangal, in the bottom of the gorge c. 2 IO $\mathrm{m}$, in wet soil on a rock wall, where water trickles down (fl. $1 / 1$ I 7 , no. 220); $Q$. Juanango, at the foot of the high waterfall, wet soil between stones, c. $225 \mathrm{~m}$ (f. $9 / 417$, no. 615 ).

Discovered by BERTERo »en las pendientes sombrías de los cerros mas elevados» and found again by GERMAIN. It probably grows in the foggy region and descends into some of the damp gorges. The specimens from Juanango have pilose leaves, with long stiff hairs spread over the entire lower surface, denser along the midrib; on the upper surface there are a few hairs scattered along the nerves. The margin is lined with hairs except near the base. These plants agree with the type as described and figured by Hooker. The Pangal specimens are larger with longer spikes and glabrous leaves, the margin often pilose toward the tip. The leaves are conspicuously thinner. This I regard as a form of extreme shade and moisture.

Area of distribution: Endemic in Masatierra.

40. P. Skottsbergii C. DC. in Skottsberg, Stud. 2o. - Syn. P. margaritifera, JoHow ex p., Estud. I22. - Plate IO.

Masafuera: in the canyon of $Q$. de las Casas, moist ledges, caves and overhanging rocks, rare (fl. $11 / 217$, no. 477). Also collected by JoHow and by the writer in Ig08; the only locality known.

Area of distribution: Endemic in Masafuera. 
4I. P. fernandeziana Miq. - JoHow, Estud. I22.

Masatierra: In the forested region, not uncommon, but not observed at a lower altitude than $400 \mathrm{~m}$. - The ridge between $Q$. Laura and $Q$. de la Piedra Agujereada, c. $500 \mathrm{~m}$; small valley above El Pangal, c. $660 \mathrm{~m}$; slopes of Co Damajuana, c. $500 \mathrm{~m}$; Q. Damajuana, $345 \mathrm{~m}$ (f. ${ }^{30} / 12$ 16, no. 2 I I); slopes of El Yunque (also JoHow); V. Colonial, C. Central, c. $400 \mathrm{~m}$, epiphytic; $Q$. del Monte Maderugo, c. $500 \mathrm{~m}$; northeast side of Co Pirámide, $580 \mathrm{~m}$, on the ground and on trees (f. ${ }^{15} / 12$ 16, no. I40); Portezuelo de Villagra, on both sides; Q. Salsipuedes (also REED), c. $650 \mathrm{~m}$ (fl. ${ }^{20} / 12$ I6, no. I69); Pto Ingles, on the central ridge, $470 \mathrm{~m}$, epiphytic. An aberrant form with leaves almost intermediate in shape between this and $P$. margaritifera was found below Portezuelo (sterile, no. I 202).

Masafuera: In the forest near Las Chozas; $Q$. del Mono, in forest, $475 \mathrm{~m}$; Q. de las Casas (JoHOW), under overhanging rocks (fl. ${ }^{11} / 217$, no. 418 ); Q. de las Vacas; $Q$. del Blindado, rocks in the forest $440 \mathrm{~m}$; C. del Barril c. $750 \mathrm{~m}$, under rocks; east slope of Los Inocentes, $840 \mathrm{~m}$, in fern forest.

Area of distribution: Chile, Frai Jorge and Valdivia; Juan Fernandez.

(Of P. nummulariaefolia Griseb. there is a specimen in Herb. Santiago labelled Juan Fernandez, but without locality, date or collector. See JoHow, Estud. 122. I exclude it from the list.)

\section{Urticaceac.}

\section{Urtica L.}

42. U. Masafuerae Phil. - JoHow, Estud. 123.

Masafuera: GERMAIN I Oct. I 854 , very common in some places according to a communication from the discoverer to JoHow.

A small annual, very like $U$. Berteroana (=U. echinata Benth. acc. to Index Kewensis), but glabrous except for the calyx and a sparse and coarse indument on the leaves. We did not see a trace of this plant; probably it is a spring herb of short duration.

Area of distribution: Endemic in Masafuera.

43. U. fernandeziana (Rich.) Ross; Skottsberg, Stud. 2o. - Syn. $U$. glomerulaeflora Steud., JoHow, Estud. I 23.

Masatierra, rare: BERTERo! GERMAIN! - V: Colonial, small quebrada on the west side (SkotTsberG I908); south side of Portezuelo de Villagra, $550 \mathrm{~m}$, two specimens observed near the road (A.-fr. $10 / 117$, no. 229).

Masafuera: first found by the writer in I908. - Q. de las Chozas, Dicksonia-grove; $Q$. del Mono, in the forest, $475 \mathrm{~m}$ (fl.-fr. ${ }^{12} / 2$ I 7 , no. 478); near the road to Las Chozas, c. $450 \mathrm{~m}$; Q. del Blindado, in forest, $370 \mathrm{~m}, 440 \mathrm{~m}$ (fl.-fr. $19 / 2$ I7, no. I 203); Las Torres, fern bed among rocks, I370 m; C. del Barril, under rocks, $985 \mathrm{~m}$; east slope of Los Inocentes, burnt place in fern thicket, c. $800 \mathrm{~m}$. Area of distribution: Endemic. 


\section{Boehmeria Jacq́.}

44. B. excelsa (Bert. ex Steud.) Wedd. - JoHow, Estud. 124.

Masatierra: The characteristic tree of the river beds, in groups along the streams in the valleys; forms the westernmost forest patch in the island. Pto Frances (Johow); El Rabanal; El Pangal, common near the entrance (A. ${ }^{11} / 12$ I6, no. I05 9 , 106 J); Q. Dainajuana, c. $200 \mathrm{~m}$, scattered trees (fl. ${ }^{6} / 12$ I6, no. 58 9); Plazoleta del Yunque, not uncommon (also JoHow); V. Colonial, slopes of C. Central, c. $400 \mathrm{~m}$; Q. Seca, stray specimens, $300 \mathrm{~m}$; Pto Ingles, west branch, fine groups by the stream in the flat part of the valley; $Q$. Juanango, $215 \mathrm{~m}$; Q. Villagra, some small trees, c. $400 \mathrm{~m}$; Q. de la Choza, solitary trees in dense forest, c. $250 \mathrm{~m}$; foot of Co Chumacera, small pure stand.

Monoecious; generally the branchlets are either $\delta$ or $q$; male flowers were not observed in female glomerules, but in male ones, which seem to be much rarer, single female flowers occurred.

Unfortunately, I have not found ripe fruits. Habitually, it is very like $B$. dealbata Cheesem. from the Kermadec Islands, as well as other Pacific species, to which $B$. excelsa probably is nearly related. It has also the appearance of Pipturus albidus Gray from Hawaii, but as far as can be judged from flowers only it is a true Boehmeria.

Area of distribution: Endemic in Masatierra.

\section{Parietaria L.}

45. P. debilis Forst. - Syn. P. humifusa, Rich., JoHow, Estud. 124.

Masatierra: B. del Padre, stony beach, faded (15/1 I7, no. 297).

Masafuera: on the beach between Casas and Mono $\left({ }^{18} / 2\right.$ I7, no. I208; JoHow collected it near this place); $Q$. de las Casas, walls of the canyon, scarce (f. $6 / 3$ I7, no. 368); Q. Angosta, in the gorge by a small waterfall.

Area of distribution: Subcosmopolitan.

\section{Loranthaceae.}

\section{Phrygilanthus Eichl.}

46. P. Berteroi (Hook. et Arn.) Reiche. - Syn. Loranthus Berteroi Hook. et Arn., JoHow, Estud. I26.

Masatierra: Bertero! BrIDGes! Parasitic, according to the former, on Myrceugenia, the commonest forest tree.

We greatly regret having been unable to rediscover this interesting plant. It is certainly very rare. I hardly think that any of the islanders, of which many spend a great deal of their time in the woods, had ever seen this, and only very few had heard of its existence, while all of them were very familiar with other species of the same genus, known as "quintral» on the mainland.

Area of distribution: Endemic in Masatierra: 


\section{Santalaceae.}

\section{Santalum L.}

47. S. fernandezianum F. Phil. - JoHOW, Estud. I27.

Masatierra: last seen in Pto Ingles, August I908, by the writer.

In 1882 D. SEPúLVEDA rediscovered the sandal wood, long thought extinct, in Pto Ingles, where, according to what he told me, he cut two trees at a low altitude above sea level. Shortly afterwards another person is said to have found one tree near Portezuelo. I do not know who destroyed this. Later (I892 ?) P. ARREDONDO found another tree in Pto Ingles about $300 \mathrm{~m}$ above sea level, and in January or February 1892 he brought JoHow to the spot. There are specimens in his herbarium from the same tree gathered by SÖHRENS I 895. In August, I908, ARRENDONDo's son GulLLERMO accompanied me to the locality. From 1892 to 1908 no second specimen had been discovered. I gave an account of this last tree in Svensk Bot. Tidskr., I9IO. When we arrived in Masatierra in I9I $\dot{6}$, we were met by the sad news that the tree had died and become cut up, so that nothing remained. Numerous pieces of the wood were offered for sale.

Masafuera: Pieces of semi-fossil wood have been found in Q. del Sándalo (P. Gutierrez, G. Arredondo), Q. del Sandalito and Q. del Varadero (GUTIERREZ).

We do not know if the Santalum once growing in Masafuera was conspecific with $S$. fernandezianum, for nobody has seen leaves or flowers.

Area of distribution: Endemic. Apparently extinct.

\section{Chenopodiaceae.}

\section{Chenopodium L.}

48. Ch. Sanctae Clarae Joh.; JoHow, Estud. I I9. - Fig. 6 a, 7 a-e.

Santa Clara: Almost confined to a small rock, called Morro del Spartán by JoHow, M. de los Alelíes by the fishermen from Masatierra, separated from the island by a narrow channel which is nearly dry at low tide (BERTERo; JoHow, fl. ${ }^{18} / 6$ I 895 ! fr. ${ }^{26} / 1$ I 7 , no. 344 ).

As JoHow's description of the flower is very short and as I have discovered two new species of the same insular type, I have found it necessary to add the following observations.

Arborescens, humile. Folia triangulari-ovata vel ovata, apice late rotundata, obtusa-obtusissima, margine irregulariter et grosse sinuato-dentata dentibus rotundato.obtusis; folia ramorum juvenilium majora, lamina 50-90 $\times 30-60 \mathrm{~mm}$, petiolo $30-45 \mathrm{~mm}$ longo. Panicula gynomonoeca; floribus $\Varangle$ circ. I,6 $\mathrm{mm}$ diam. tepalis suborbicularibus circ. I $\mathrm{mm}$ longis, margine late hyalino sacpe irregulariter dentato, dorso eximie calloso-costatis, praecipue ad basin pilis vesiculosis vestitis. Stamina maturitate breviter exserta, antheris $0,4 \mathrm{~mm}$ longis. Ovarium subglobosum, stylis 2 ad basin perfecte liberis. Flores $q$ minores tepảis $0,6-0,7 \mathrm{~mm}$ solum longis (dein paulo auctis); staminodia 5 minuta. Fructus 

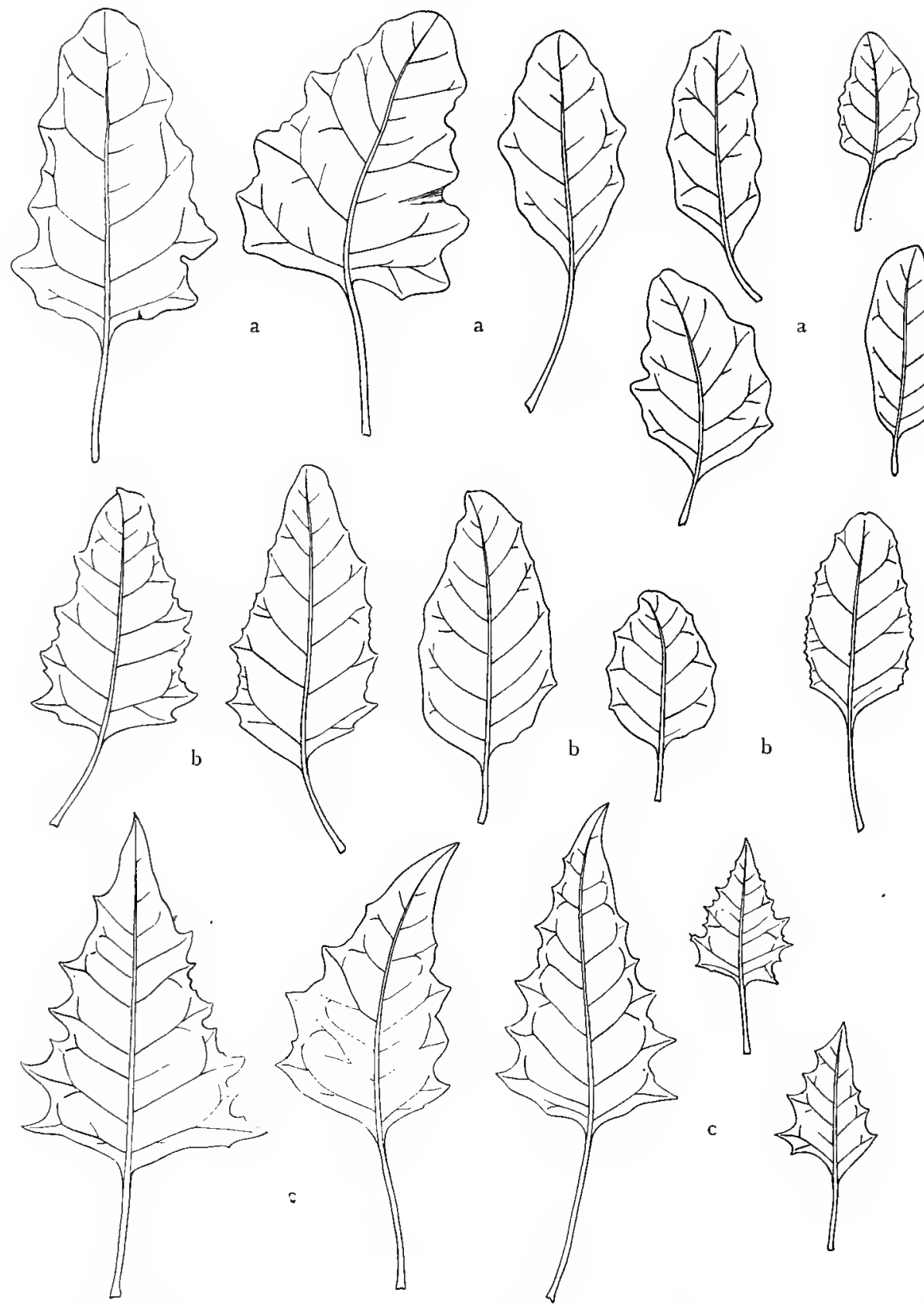

Fig. 6. Leaves of a Chenopodium Sanctae Clarae, b Ch. Crusoeamum, c Ch.nesodendron, $\frac{1}{2}$ nat. size.

crasse lenticularis, apice subplano-convexus stylis patentibus. Semen horizontale, lenticulare margine obtuso, nitidum, nigro-castaneum, minute punctulatostriatum, $\mathrm{I}, 2_{2} \mathrm{~mm}$ latum et $0,5 \mathrm{~mm}$ crassum.

Area of distribution: Endemic in Santa Clara. 
*49. Ch. Crusoeanum nov. spec. - Fig. 6 b, $7 \mathrm{f}-\mathrm{k}$. Plate 1 I.

Frutescens, ad $50 \mathrm{~cm}$ vel paulo ultra altum, lignosum. Truncus in fissuris rupium absconditus haud accessus, paulo supra basin ramosus, ramis crassioribus ad $9 \mathrm{~mm}$ diam.; cortex griseo-viridis vel brunnescens, in ramis junioribus etiam viridis, laevis. Folia versus apicem ramorum subconferta, inferiora mox caduca, longe petiolata, $40-80 \mathrm{~mm}$ longa et $20-45 \mathrm{~mm}$ lata, petiolo $\mathrm{I} 5-30 \mathrm{~mm}$ longo, ovato-triangularia, basi subtruncata vel late rhomboidea, apice rotundatarotundato-acuminata, sat obtusa, subintegra vel praecipue basin versus irregulariter dentata usque serrata denticulis brevibus acutis, supra viridia, subtus glaucescentia pilis vesiculosis dense vestita; textura tenuis; nervi flavescentes subtus prominuli. Inflorescentia gynomonoeca paniculata, in ramis terminalis, aphylla, pyramidata, valde laxa ramis patentibus; flores subsolitarii; bracteae minutae. Flores $\Varangle 1,5-1,7 \mathrm{~mm}$ diam., tepalis late ovatis $I-I, z \mathrm{~mm}$ longis cucullatis basi concretis, vesiculoso-pilosis, valde viridi-callosis, margine hyalino sat irregulari. Stamina primo inclusa dein breviter exserta, filamentis tepalis paulo longioribus vel aequilongis, thecis ovoideis $0,7-0,8 \mathrm{~mm}$ longis. Ovarium ovoideo-subglobosum vel ovoideo-conicum, $0,6 \mathrm{~mm}$ altum, apice subiter contractum stylobasin formans; styli 2 liberi erecto-patentes, e basi incrassata filiformes. Flores $q$ tepalis aliquantum minoribus haud $1 \mathrm{~mm}$ longis (dein auctis), staminodiis 5 minutis. Fructus lenticularis, $1,5-1,6 \mathrm{~mm}$ diam., stylopodio distincto stylisque erectis, pericarpio opaco punctulato. Semen fere ut in praecedente.

Masatierra: on a rather inaccessible mountain wall in the bottom of the Pangal gorge, in fissures c. $220 \mathrm{~m}$, rare (fl.-fr. $1 / 117$, no. 227).

Differs from $C h$. Sanctae Clarae in the more slender habit, the shape of the leaves and fruit etc., as seen from my description and figures.

Area of distribution: Endemic in Masatierra.

*50. Ch. nesodendron nov. sp. - Fig. 6 c, 7 1--o.

Arbor vera quamquam pumila, ad $2,8 \mathrm{~m}$ alta visa; truncus primarius crassus, paulo supra basin ad $12 \mathrm{~cm}$ diam., usque ad apicem \pm distinctus, tota longitudine ramis vestitus, inferioribus mortuis; cortex viridis - viridi-stramineus. Folia versus apicem ramorum conferta, inferiora mox caduca, triangularia, basi truncata vel angustata, breviter decurrentia, \pm longe et saepe permanifeste acuminata, acuta, margine \pm profunde, grosse et irregulariter dentato-serrata sed versus apicem saepius subintegra, dentibus acutis triangularibus, majoribus interdum denticulis $\mathrm{I}-2$ instructis; lamina supra viridi-flavescens, subtus viridiglauca vesiculoso-pilosa nervis pallidis prominulis; textura sat tenuis; lamina in ramis florigeris (num. 550) circ. $30-40 \times 20-25 \mathrm{~mm}$, petiolo $15-50 \mathrm{~mm}$ longo, in innovationibus (num. 523) majuscula, ad $80--95 \mathrm{~mm}$ longa et $45-65 \mathrm{~mm}$ lata, petiolo $34-45 \mathrm{~mm}$ longo. Panicula in ramis terminalis, pyramidata, $4-6 \mathrm{~cm}$ alta, sat densa, gynomonoeca. Flores $\Varangle \mathrm{I}_{3}-\mathrm{I}, 5 \mathrm{~mm}$ diam., tepalis ovatolanceolatis obtusis valde cucullatis dorso crasse callosis margine late hyalinis \pm denticulato-ciliatis. Stamina perigonio paulo longiora breviter exserta. Ovarium ovoideo-conicum $\mathrm{I}, 5 \mathrm{~mm}$ altum in rostrum longum productum; styli 2 basi subincrassati valde patentes liberi. Flores $q$ tepalis minoribus, staminodiis 5 minutis. Fructus longe rostratus, $2-2,5 \mathrm{~mm}$ longus, $1,5 \mathrm{~mm}$ diam., rostro $\mathrm{I}-\mathrm{I}, 4 \mathrm{~mm}$ 


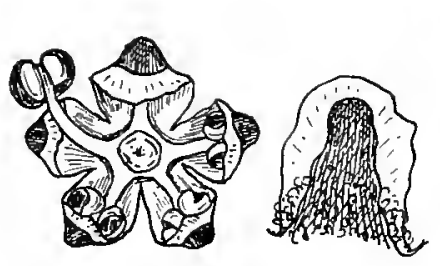

a

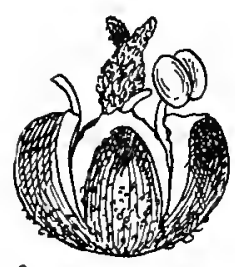

f
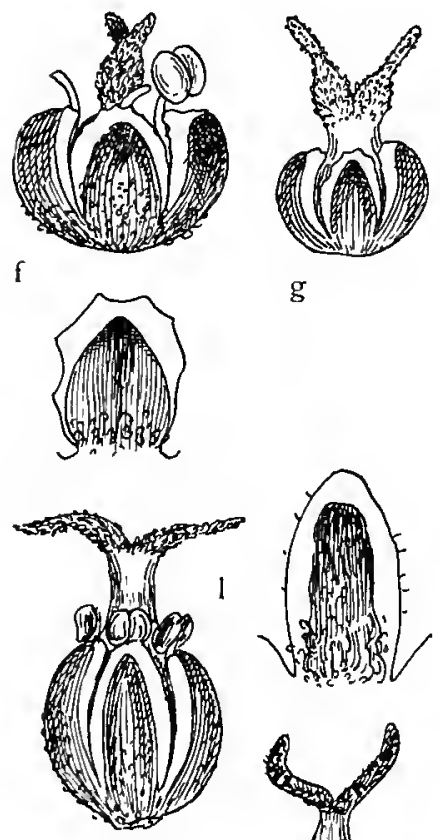

g
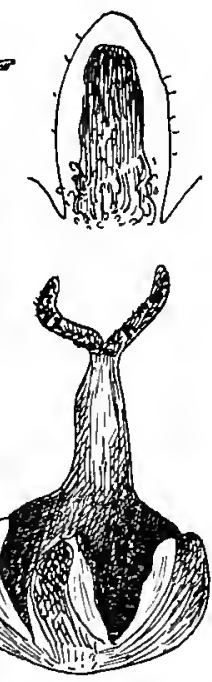
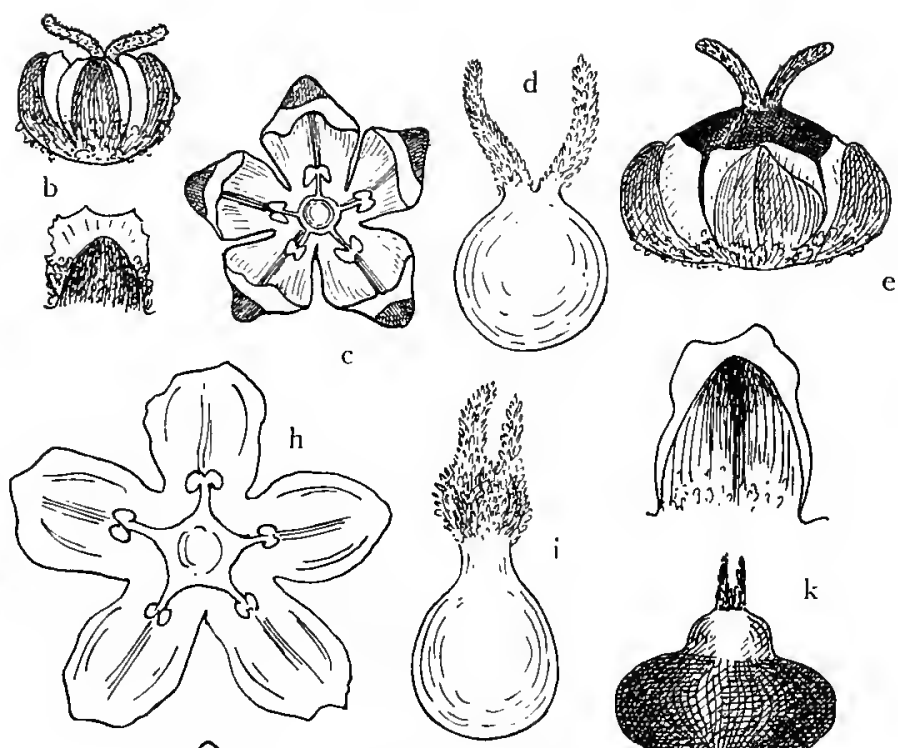

e

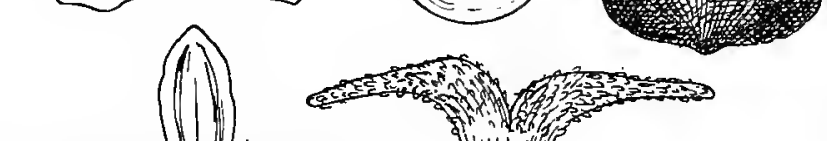

n
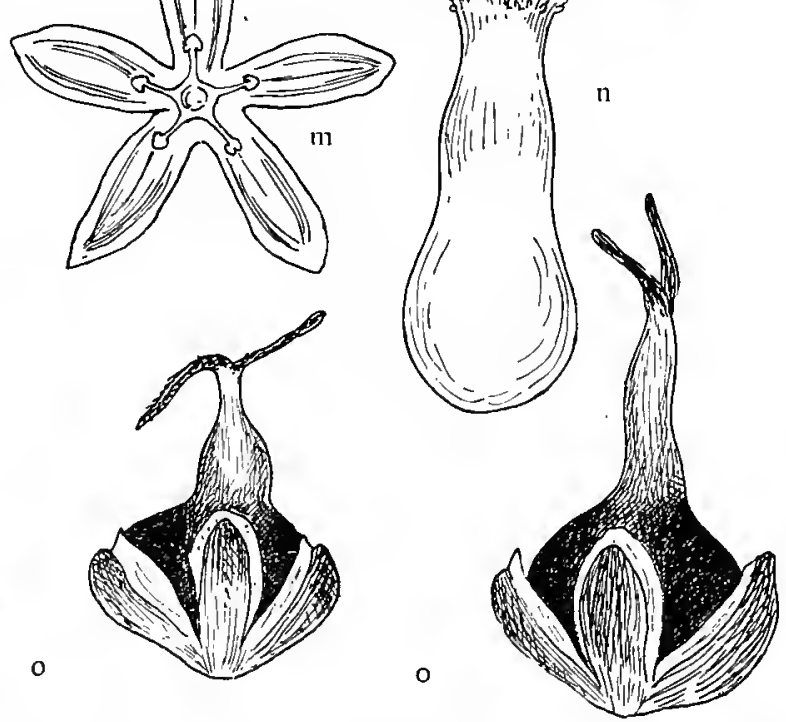

Fig. 7. a-e Chenopodium Sanctae Clarae: a $\not \subset f$., (pistil removed), and one tepal, b $\mathrm{Q} f$. and one tepal, c $q$ fl. showing staminodes, d pistil, e fruit. $f-k$ Ch. Crusoeanum: $f$ of fl. and one tepal, $g$ of $\mathrm{fl}$., $\mathrm{h}$ \% fl. showing staminodes, $\mathrm{i}$ pistil, $\mathrm{k}$ fruit and tepal. $1-0$ Ch. nesodendron: 1 ' $\mathrm{d}, \mathrm{i}, \mathrm{n}, \times 30$, all others $\times 15$.

longo, pericarpio tenui opaco punctulato. Semen fere ut in praecedentibus, horizontale vel leviter obliquum, circ. $\mathrm{I}_{3} \mathrm{~mm}$ diam. et $0,7 \mathrm{~mm}$ crassum.

Masafuera: Slope near Las Chozas, c. $500 \mathrm{~m} \mathrm{(fr.} 3 / 3$ 17, no. 550); lower slopes of Los Inocentes, in the grass and fern beds, c. $500 \mathrm{~m}$; Q. de la Loberia, 
one large specimen in the gorge among rocks (no. 523). The species is everywhere persecuted by the indefatigable goats.

Differs from the other species in the much greater size, the shape of the leaves and fruit, etc. Seeds from no. 550 were sown in the Gothenburg Garden in 1918 , the plants are quite typical, but have not yet produced flowers. Their habit is truly arborescent.

Area of distribution: Endemic in Masafuera.

The three Juan Fernandez species of Chenopodium, each confined to a single island, are related to Ch. paniculatum Hook. from North America, Perú and Chile, ranging from $49^{\circ} \mathrm{N}$. to $32^{\circ} \mathrm{S}$. This is a polymorphic species that was treated by J. MURR in Oesterr. Bot. Zeitschr., it is herbaceous or shalbstrauchartig» and the leaves mostly entire. The island species are probably also related to $C h$. sandwicheum Moq. from Hawaii.

\section{Salicornia L.}

5I. S. peruviana Kunth. - JOHOW, Estud. I2O.

Masatierra: here and there along the east and north sides of the island, forming patches above the highwater line (fl. ${ }^{15} / 1$ I 7 , no. 299).

Santa Clara (also observed by JoHow).

Masafuera: GERMAIN; near entrance to $Q$. del Varadero and $Q$. Angosta; Playa Ancha; Tierras Blancas (no. 433); Lobería Vieja (JoHow).

Area of distribution: West coast of South America; Juan Fernandez.

Aizoaceae.

\section{Tetragonia L.}

52. T. expansa Murr. - JoHow, Estud. I I6.

Stony beaches, rather uncommon.

Masatierra: Pta San Carlos, scattered (fl.-fr. ${ }^{12} / 12$ 16, no. 126, also observed by JoHow); B. del Padre (JoHow).

Santa Clara: Morro de los Alelíes (unr. fr. ${ }^{26} / 1$ 17, no. 347 ; also observed by JoHow).

*Masafuera: between Casas and Vacas (fl.-unr. fr. ${ }^{13} / 2 \mathrm{I} 7$, no. 512 ); Playa Ancha (fr. ${ }^{22} / 2$ 17, no. 1206). - New for this island.

Area of distribution: Coasts and islands of the Pacific.

Caryophyllaceae.

Spergularia Presl.

53. S. confertiflora Steud. Flora 1856,425. - S. rubra, JoHow, Estud. I I 8.

STEUDEL based his species (erroneously called confertifolia by JOHOW) on BERTERo no. 143 I from Masatierra: "floribus versus apicem ramorum axillaribus 
et terminalibus non paniculatis sed ob folia magis approximata confertioribus», thus a form with a contracted, leafy inflorescence. But BERTERo's material includes, under the same number (Herb. Kew!) another form with long, rather lax, terminal cymes, and there are numerous transitions between these two types. A similar form was described by PHILIPPI as Arenaria rubra var. polyphylla (Masafuera, GermaIn!). RoHrbach, Linnaea XXXVII.232 considered this to be a good species and called it Spergularia polyphylla (Phil.) Rohrb.: \$hab. in insulis Juan Fernandez et Masafuera (PrILlipPI)», but the specimens from Masafuera were certainly not collected by PHILIPPI, who never visited this island, so the statement probably refers to GERMAIN's plant. In Herb. Santiago are specimens collected in Masatierra by PHILIPPI (186I) and by REED (I872), but I do not know which of these were considered by ROHRBACH to belong to S. polyphylla. The species was characterized by the structure of the seed test, the papillae were described as one-sided, flattened, often slightly curved. REICHE, Flora I. 197 retained this as Tissa polyphylla („Syn. S. confertiflora Steud.»), but quoted plants from Masafuera only.

Another species to be considered here is S. remotiflora Steud. l. c. 424 from Chile. According to the description this must be exactly like the lax form of confertiflora. REICHE, however, brought it to Tissa media, without having seen the type. As I have no means to revise the whole genus, I have retained the island species as $S$. confertiflora. This is a correct name, given to a Juan Fernandez plant collected by BERTERo; I have seen the type material and my plants as well as those collected by PHILIPPI, JoHow etc. belong to the same species. HEMSLEY and JOHOW were of the opinion that all the forms found on Juan Fernandez were varieties of S. rubra Presl (S. campestris [I.] Aschers.), which has become introduced into South America. But $S$. confertiflora is a perennial, stout, lignified, almost shrubby species; in the axils are dense glomerules of small leaves, giving to the stem the appearance of being clothed with leaves; the stipules of two opposite leaves are entirely united into one interpetiolar stipule on each side; the pedicels are never reflexed. I find it impossible to regard the island species as only a form of $S$. campestris, but believe that it is indigenous in Central Chile.

Habitually, S. confertiflora varies a great deal. It is contracted or lax, nearly glabrous or glandulose, the leaves long and narrow or short and broad, the petals white or rosa. Undoubtedly it includes an aggregation of forms, that ought to be cultivated in order to get an idea of their systematic value. Two will be listed here under separate names, var. polyphylla in the sense of ROHRBACH, with oblique seed papillae, and var. glaberrima, a perfectly glabrous, yellowish green form from Masafuera. I have sown seeds of one form from Masatierra, and of polyphylla and glaberrima from Masafuera. The plants are young and have not flowered (August, 1921); they are perfectly distinguishable from each other.

KINDBERG, in his monograph, does not mention $S$. confertiflora or polyphylla, and REICHE does not quote the monograph, where several Chilean species were described and figured.

Masatierra: lava beds of the sea coast, one of the very few plants thriving on the dry, barren cliffs. Pta San Carlos (fl.-fr. ${ }^{12} / 12$ I6, $9 / 1$ I7, no. I23; also 
observed by JoHow); Pto Ingles; Tres Puntas (JoHow); B. del Padre (fl.-fr. 15/1 I7, no. 296); Co Negro (f..-fr. 7/1 I7, nos. 262, 266); Pta Larga; Tierras Blancas (fl. $6 / 8$ 17, BÄCKSTRÖM no. 1208).

Santa CIara, also observed by Johow; Morro de los Alelíes (fl. ${ }^{26} / 117$, no. 349).

var. polyphylla (Phil.) Skottsb.

Masatierra: PHILIPPI! REED!

Masafuera: Germain! - Scattered along the coast from B. Toltén (fr. $2 / 2$ 17, no. 470) to Playa Ancha; common at the Casas entrance (fl. fr. ${ }^{16} / 2$ I7, no. 387); Q. del Varadero (fl. ${ }^{12 / 8}$ I 7, no. 569). — Variable in habit, but generally densely pubescent.

var. glaberrima nov. var. - Humilis, luteoviridis tota glaberrima, folia carnosa sat lata, mucronata, subpungentia, stipulis interpetiolaribus late triangulatis apice \pm laceratis; inflorescentia compacta foliosa; petala alba; capsula interdum sepalis paulo longior; semina parce tuberculata-sublaevia.

Masafuera: entrance to the Casas Valley (fl.-fr. ${ }^{10} / 2$ I7, no. 411 ).

Area of distribution of $S$. confertiflora: Central Chile; Juan Fernandez.

\section{Paronychia L.}

54. P. chilensis DC. - JoHow, Estud. 118.

Masatierra: barren slopes in the west part of V. Colonial, rare (fr. Dec. 1916, no. I5); the treeless western slopes of the island (SöHrENS).

Remarkably enough this plant escaped the attention of all earlier visitors except one; still, it may not be of recent introduction.

Area of distribution: Chile, Coquimbo to Valdivia; Masatierra.

\section{*Ranunculaceae.}

\section{Ranunculus L.}

*55. R. caprarum nov. spec. - Fig. 8.

Erectus, villosus, ad $0,75 \mathrm{~m}$ altus. Rhizoma sat breve, crassum, ramosum. Folia basalia latissime vaginantia, longissime petiolata; lamina crasse chartacea, obscure viridis, supra adpresse pilosa, subtus praecipue secus nervos longius sericeo-villosa, nervis reticulato-palmatis subtus, versus basin valde incrassatis, ambitu cordato- vel reniformi-orbicularis, subpeltata, fere ad basin tripartita; lacinia centralis late cuneato-oblonga vel suborbicularis, \pm distincte lateque petiolulata, ima basi cuneata, ad $1 / 4-1 / 3$ trilobata, lobis \pm profunde lobulatis, lobulis dentato-serratis; laciniae laterales rectangulato-semiorbiculares, subsessiles, basi late cuneatae et integrae, ceterum inciso-lobatae, lobulatae nec non dentatae; petiolus costato-striatus, patente, longe nec non sat dense villosus, crassus; vagina subglabra vel extus \pm adpresse pilosa. Folia majora visa petiolo (cum vagina) $29-46 \mathrm{~cm}$ longo et circ. $5 \mathrm{~mm}$ crasso; vagina circ. $6-9 \mathrm{~cm}$ 
longa basi $3,5-4 \mathrm{~cm}$ lata; lamina $14-19 \mathrm{~cm}$ longa et $17-23 \mathrm{~cm}$ lata. Caulis sulcato-striatus, inferne villosus, superne minus hirsutus, repetiter ramosus. Folia caulina inferiora pauca, basalibus \pm similia, sessilia sed longe vaginantia, profundius divisa; summa ornithopodioidea, brevissime vaginantia, profunde tripartita, lobis subintegris. Flores sat numerosi, inflorescentiam subracemosam sat expansam laxam foliosam formantes, pedunculo usque ad $5-6 \mathrm{~cm}$ longo, sub flore densius villoso suffulti. Sepala.... Petala .... Stamina .... Receptaculum ovoideo-

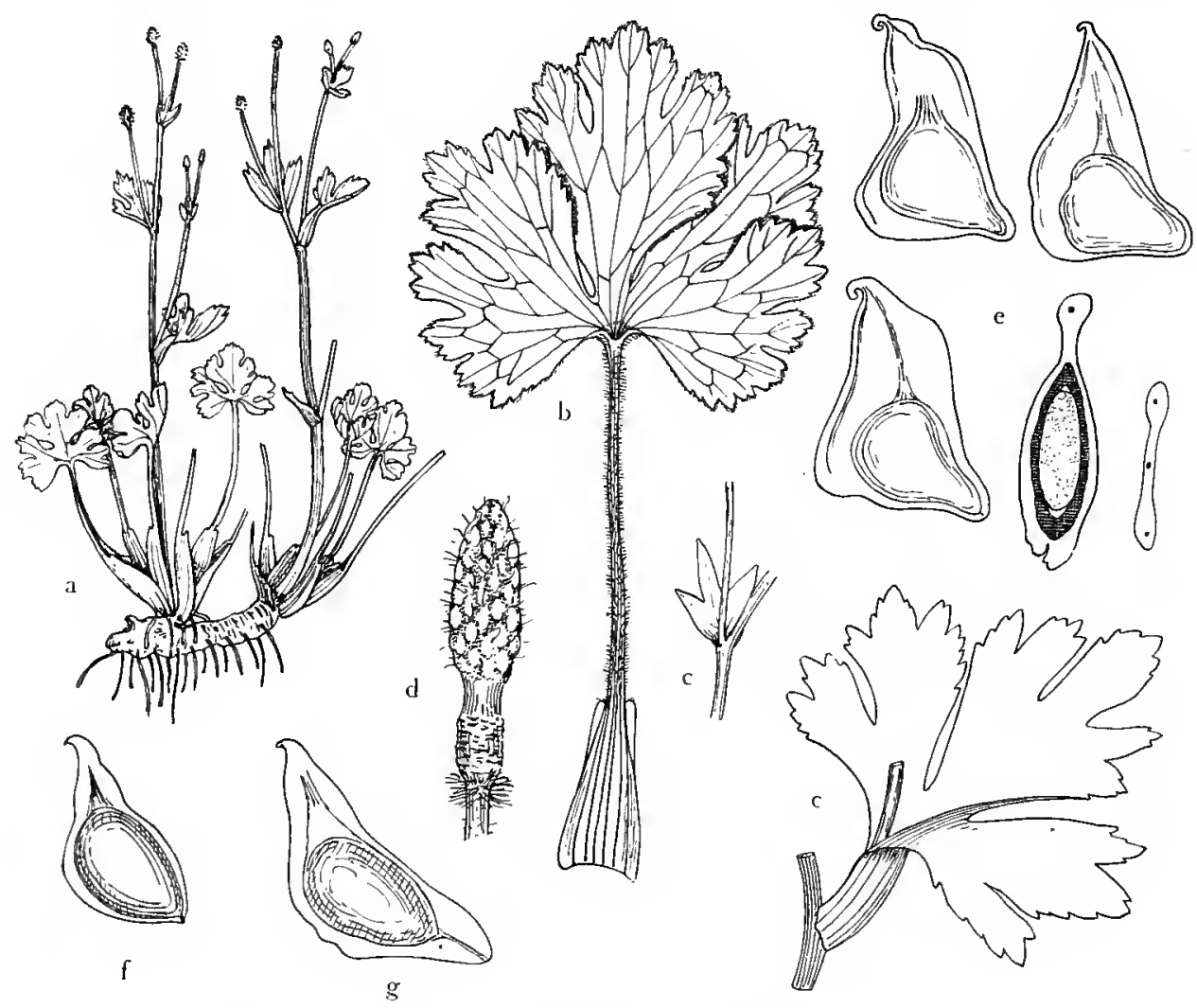

Fig. 8. a-e Ranunculus caprarum: a plant after a rough sketch from nature, much reduced; b basal leaf, c cauline leaves, $\frac{1}{2}$ nat. size; d receptacle, $\times 4$; e three carpels, $\times 4$, and cross sections through carpel, $\times 6$. f carpel of R. hawaiensis, $\mathrm{g}$ of $R$. Haastii, $\times 4$.

conicum, 4-6 mm longum, parce pilosum. Achaenia triangularia, valde compressa, $6-7 \mathrm{~mm}$ longa et $3-4 \mathrm{~mm}$ lata, glabra; nux cuneato-lenticularis, versus apicem late alato-marginata; ala in stylum apice filiformi-recurvum stigmatiferum attenuata.

Masafuera: near the goat track along the western precipice, north of the Casas gorge, C. I $200-\mathrm{I} 300 \mathrm{~m}$, rare (ripe fr. ${ }^{5-7 / 3} \mathrm{I7}$, no. 366 ).

I deeply regret having to describe this on incomplete material. The anatomical structure of the achene shows that it belongs to Ranunculus, and there is no doubt that it is a new species. All the plants found were in fruit, but most of them had not even the receptacles left, as the flower stalks had 
been bitten off by the goats; in fact, not one intact specimen was seen and most of them were badly damaged, so that the existence of the species seems to be seriously threatened. As far as I can find, $R$. caprarum has no relative in America. Habitually, it belongs to the type of $R$. Lyallii Hook. fil., insignis Hook. fil. and nivicola Hook., all from New Zealand; it is remarkably like the last mentioned, which differs in the less deeply cleft basal leaves and in the unwinged achenes. But in another New Zealand species, R. Haastii Hook. fil. (Fig. $8 \mathrm{~g}$ ), which has a different habit, we find the same flat, winged achenes. It is possible that $R$. hawaiensis A. Gray (Fig. $8 \mathrm{f}$ ) and R. mauiensis A. Gray from Hawaii belong to the same group; their leaves are more divided with stalked segments and the nut is barely winged, but there is a distinct trace of a wing on the style. I regard $R$. caprarum as another addition to the old Pacific element in the flora.

Area of distribution: Endemic in Masafuera.

\section{Berberidaceae.}

\section{Berberis L.}

56. B. corymbosa Hook, et Arn. - JoHow, Estud. I15. - Fig. 9 c-d.

Masatierra: not uncommon along the high ridges but never occurring in considerable number nor forming thickets; sometimes also found in the open forest. - Co Centinela, c. $400 \mathrm{~m}$; El Pangal, near the entrance and on the walls of the gorge, c. $200 \mathrm{~m}$; Q. Damajuana, open forest on steep slope, $345 \mathrm{~m}$; in the gap between Damajuana and Yunque, 550-600 m (unr. fr. ${ }^{18} / 12$ I6, no. 158); high peak between Pangal and V. Colonial, $365 \mathrm{~m} ; \mathrm{V}$. Colonial, C. Central, $570 \mathrm{~m}$ (also observed by JoHow); Portezuelo de Villagra, a few small shrubs near the SELKIRK tablet, c. $600 \mathrm{~m}$ (fl. ${ }^{3 / 12}$ I6, no. 36); Q. del Monte Maderugo, steep rocks; $Q$. Seca, open forest, c. $500 \mathrm{~m}$; C. Salsipuedes (also observed by JoHOw), 400-600 $\mathrm{m}$, in brushwood and forest, on the ridge and on both slopes; Pto Ingles, central ridge, $470 \mathrm{~m}$; Q. Vaqueria, in open forest, c. $250 \mathrm{~m}$; mountain spur W of El Yunque, in forest, $530 \mathrm{~m}$; Q. Villagra, higher parts, scattered. $B$. paniculata Phil. was retained as a species by HEMSLEY but reduced to $B$. corymbosa by REICHE and JoHOw. After having examined the type in Herb. Santiago I can only subscribe to the opinion of the latter. From the description of PHILIPPI (narrow leaves!) one would perhaps conclude that $B$. paniculata is the same form that I have described below from Masafuera. This is not the case; the leaves vary in $B$. corymbosa, but $B$. paniculata falls within the limits if this. Bracts in the panicle are found in otherwise typical corymbosa.

Area of distribution: Endemic in Masatierra.

*57. B. masafuerana nov. spec. - Fig. 9 a-b.

Frutex metralis et ultra, ramis tenuibus cortice obscure rubro-atro-violaceo, leviter sulcato in junioribus saltem lucido sicut vernicoso, ramellis distantibus. 
Folia primaria plantulae juvenilis suborbicularia, grosse et irregulariter sinuata, interdum dentibus nonnullis pungentibus munita, lamina ad $2 \mathrm{~cm}$ longa et lata, petiolo circ. $2 \mathrm{~cm}$ longo apice vel paulo infra distincte articulato. Spinae sat mites, nondum pungentes, plerumque simplices, rarissime segmentis I -2 lateralibus munitae, 3-5 mm longae. Ramelli foliigeri brevissimi, distantes. Folia secundatia anguste obovato-elliptica-elliptico-lanceolata, coriacea, discoloria subtus pallida, obtusa, basi manifeste angustata, reticulato-nervosa; lamina $2-3,5 \mathrm{~cm}$ longa et $0,6-\mathrm{I}, 3 \mathrm{~cm}$ lata; petiolus tenuis vulgo $2-3$, rarius ad $6 \mathrm{~mm}$ longus, paulo supra basin articulatus. Cetera ignota.
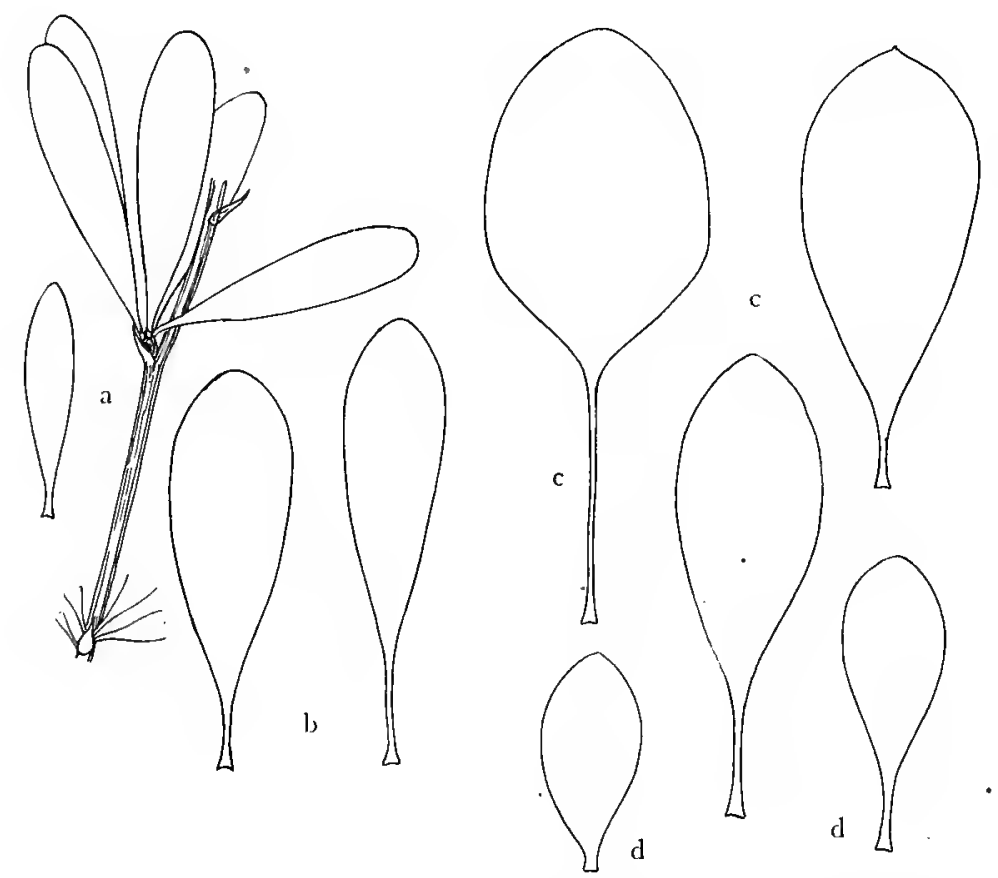

Fig. 9. $a-b$ Berberis masafuerana: a part of branch and one small leaf, b largest leaves seen. c-d B. corymbosa: c ordinary leaves, d exceptionally narrow leaves. All natural size.

Masafuera: Q. de las Casas, one seedling by the side of a waterfall, $215 \mathrm{~m}$; larger shrubs seen on the wall of the canyon in an utterly inaccessible place, but some branches were obtained by means of a lasso (no. 503); Q. de la Lobería, one shrub on a steep rock in the stream.

Unfortunately, all specimens observed were sterile. B. masafuerana comes very near $B$. corymbosa, but differs in the colour of the cortex, in the much narrower and more coriaceous leaves and in the slender habit. I have never seen anything like this form in Masatierra, so I am confident that the flower and fruit will offer structural differences.

Area of distribution: Endemic in Masafuera. 
Magnoliaceae.

Drimys Forst.

58. D. Winteri Forst. var. confertifolia (Phil.) Joh.; JoHow, Estud. II3.

Masatierra: One of the conmonest forest trees, ranging from 200 or $300 \mathrm{~m}$ to the highest ridges and forming the edge of the forest in wind-swept places, where few other trees thrive. In the foggy region very old and large trees were observed, with a thickness at the base hardly reached by any other tree in the islands. Drimys inhabits the whole forested belt of Masatierra from Pto Frances to Co Chumacera. Coll. fl. $3 / 12$ I6, no. $6,8 / 12$ I6, no. 88 , fr. ${ }^{21} / 4$ I7, no. $88 \mathrm{~b}$.

Masafuera: in the higher parts of the montane region, generally forming the limit of the forest; not seen at a much lower altitude than $500 \mathrm{~m}$; Pasto, Chozas and Mono valleys, 475-I $100 \mathrm{~m}$; one tree at the Correspondencia Camp, I $30 \mathrm{~m}$; ravine north of this place, c. $1200 \mathrm{~m}$, greatest altitude observed; on the western precipice, solitary trees above Buque Varado; C. del Barril, to I I $10 \mathrm{~m}$ (fr. $1 / 317$, no. 371 ); east slope of Los Inocentes, 740-1000 m.

The oldest name for the island Drimys seems to be $D$. confertifolia Phil. Anal. Univ. Chile I 856 (May), I63; in July the same year STEUDEL published his $D$. fernandeziana. REICHE, Flora I.27, used the combination $D$. Winteri var. fernandeziana Steud., for he quoted Bot. Zeit. 1856 (Sept.!) for D. confertifolia Phil. STEUDEL did not, however, describe it as a variety, but as a species, and thus we may use the name confertifolia (Phil.) Johow. According to STEudeL the island form differs from continental ones in the narrower leaves, which are blunt or hardly acute, rufescent above, pale below and more aggregated, and in the dioecious flowers. PHILIPPI advanced that the leaves are densely aggregated, smaller, less whitish below and much shorter petiolate. MiERS, Ann. and Mag. Nat. Hist. I 858, 48, described it as D. fermandezianus Miers (without quoting other authors); the description was reprinted and an unsatisfactory figure added in Contr. to Botany I (I86I) I37, Pl. $27 \mathrm{~B}$. The differences between Miers' species and $D$. chilensis DC. are not at all better defined by him than by other authors. JoHow, who regards $D$. confertifolia as a variety, stated that it differs in the smaller and more densely clustered leaves, and says that the trees in Masafuera have more polished leaves than those from the other island. REICHE 1. c. 27 described the leaves as »angostamente oblongas, casi lineares, muy cortamente pecioladas».

I shall not enter upon the question whether the continental forms all belong to one species or not; but I cannot separate $D$. chilensis DC. or paniculata Steud. from $D$. Winteri, and I cannot regard the Juan Fernandez plant as specifically distinct. It is true that many of the herbarium specimens studied by STEUdel, Miers, etc. have the leaves of the flowering branches comparatively small and narrow, but if we study the living plant, we shall find that there is a considerable variation in the size of the leaves, which often attain $12-13 \times$ $3-4 \mathrm{~cm}$, quite normal figures in continental forms. I need not tell that the rufescent upper surface of the leaves spoken of by STEUDEL is due to desicca- 
tion. The colour of the lower surface shows the same considerable variation as in other forms. The flowers are not dioecious, but bisexual and quite typical, and do not differ in size or shape from Chilean specimens. The only character remaining is the clustered leaves, but even in this case there is a cousiderable variation between different trees and also between different branches of the same tree. Generally, the short internodes give to the island Drimys a somewhat different habit, but cultivation alone will decide upon the value of this character. A distinct tendency to the development of a form with shorter internodes was observed in the introduced Aristotelia maqui, both by JoHOw (1. c. 108) and by the writer.

Area of distribution: Not counting the tropical forms, $D$. Winteri inhabits Chile from Frai Jorge (an isolated locality) to Cape Horu, and Juan Fernandez.

\section{Lactoridaceae.}

Lactoris Phil.

59. L. feruandeziana Phil. - JoHOW, Estud. I I4. - Plate I2, fig. I.

Masatierra: in the damp montane region, confined to the dense and humid forests above $500 \mathrm{~m}$, rate. - C. Chifladores, steep slope above Pto Frances, c. $500 \mathrm{~m}$, about a dozen plants (past $\mathrm{fl} .{ }^{17} / 4 \mathrm{I} 7$, no. 622); forests of El Yunque (Johow); V. Colonial, C. Central, one plant $510 \mathrm{~m}$, several $520 \mathrm{~m}$ (f. $18 / 1 \mathrm{I} 7$, no. 303); Portezuelo de Villagra (also observed by JoHOw), one small specinen, $570 \mathrm{~m}$; mountains at the back of Pto Ingles (JOHOW); mountain ridge west of El Yunque, c. $500 \mathrm{~m}$, very rare (fr. ${ }^{24} / 4 \mathrm{I} 7$, no. 629); highest part of the Villagra Valley below Portezuelo, some fine shrubs at the roadside, $510 \mathrm{~m}\left(\mathrm{fll}{ }^{8} / 117\right.$, no. 230$)$.

Area of distribution: Endemic in Masatierra.

\section{Cruciferae.}

\section{Cardamine L.}

6o. C. chenopodiifolia Pers. - Syn. C. fernandesiana (Phil.) Joh.; JoHow, Estud. I Io.

Masatierra: GERMAIN; REED!

Unfortunately, no trace was seen of this interesting plant. GERMAIN collected it in October, I854, REED in September, 1872; it is an annual, developed in the spring and probably of short duration, and this explains that we did not find it. Perhaps it did not appear at all in I9I6 on account of the very dry spring. It is also possible that it has become very rare or that it has disappeared altogether. As it is unknown in Perú and Chile, we have no good reason to regard it as accidentally introduced.

I am convinced that SCHU LZ (ENGLER's Jahrb. XXXII.443)was right in bringing Heterocarpus fernandezianus Phil. to Cardamine chenopodiifolia; when comparing the former with material of the latter from Uruguay, Brazil and Bolivia, I came 
to the same conclusion. Certainly, the distribution is quite puzzling and different from that of all other species indigenous in the islands, which led me to the conclusion (Stud. 19) that it had become introduced with the human traffic.

Area of distribution: Bolivia, Brazil, Argentina, Uruguay.

61. C. flaccida Cham. et Schlecht. - Syn. C. alsophila Phil, JoHow, Estud. III.

Masatierra: streams and other wet places, local. Pto Frances (JoHow); El Pangal, moss mats in the stream near the entrance; wet moss cushions by the waterfall, $215 \mathrm{~m}$ (f. pilos $\alpha$ O. E. Sch., fl.ffr. $1 / 1$ I7, no. 219 - "nonnulla specimina interdum ad subspeciem alsophila spectant», scr. O. E. ScHU1.Z in sched.); Q. Damajuana, moss mats at a small waterfall, $250 \mathrm{~m}$, common (prol. depressa O. E. Sch., ff. ${ }^{6} / 12$ 16, no. 57 ); Q. Juanango, by the stream (f. pilosa, fl.-fr. $9 / 417$, no. 603); south side of Portezuelo (JоHOw); Co Chumacera, shady corner in wet soil at the small waterfall in the Boehmeria-forest (f. integra O. E. Sch., fl.-fr. $6 / 1$ (7, no. 25 I).

Area of distribution: Widely dispersed in the warm and temperate parts of South America, in Chile in the southern provinces. Prol. depressa was collected near Talcahuano, var. pilosa near Valparaiso and in Masatierra, f. integra in "Chile" (leg. BERTERo). What Schulz calls typical alsophila has not been reported from Juan Fernandez.

62. C. Krüsselii Joh., JoHow, Estud. I I 2.

Masafuera: Forest northwest of Q. de las Casas (JoHowl); Q. de la Lobería, by the stream (fr. ${ }^{17} / 217$, no. 479 ).

We made a diligent search for this species in ali the forest patches northwest of the Casas Valley, but without result. The plants collected in the new locality differ from the type in being almost glabrous, and were distinguished by O. E. Schulz as f. glabrescens. According to the same authority, C. Krïs. selii is related to the chilean $C$. vulgaris Plit.

Area of distribution: Endemic in Masafuera.

Saxifragaceae.

\section{Escallonia Mutis.}

63. E. Callcottiae Hook. et Arn. - Syn. E. fernandesia Phil. - JoHow, Estud. I00.

Masatierra: One of the commoner plants, rather abundant on all the ridges from Pto Frances to $Q$. Jnanango, but also found on the lower barren slopes down to the sea level. Scattered on the south side from Villagra to Pta Larga. Fl. Dec.-April (nos. 2, 95, 257), fr. in April.

Very variable in size, a small tree or, on dry stony ground, a trailing shrub. Leaves small or large, flowers generally paniculate, but sometimes racemose, colour of corolla a more or less deep rosa to crimson.

Area of distribution: Endemic in Masatierra.

9-20100. The Nat. Hist. of Juan Fernandez and Easter Isl. Vol. II. 
Rosaceae.

\section{Rubus L.}

64. R. geoides Sm. - Skottsberg, Stud. Io.

Masafuera: Not uncommon in the alpine region, but not observed at a lower altitude than $1000 \mathrm{~m}$. Highland north of Casas, I130-I370 m (fr. Feb. I9I7, no. 404); C. del Barril, $1290 \mathrm{~m}$ (no. 538); Los Inocentes, from I375 m to the top; ridge between $Q$. Inocentes and $Q$. Angosta, c. IO0O m. - Discovered by the writer in 1908 .

Area of distribution: Patagonian Andes (two localities; one far north, $38^{\circ}$, needing confirmation); West Patagonia; Fuegia; Falkland Islands; Masafuera.

\section{Margyricarpus Ruiz et Pav.}

65. M. setosus Ruiz et Pav. subsp. digynus Bitter, Skottsberg, Stud. 9. --- JoHow, Estud. 9I.

Masatierra: on the low, dry slopes below the forest region, also in the western half of the island and on the high ridges above the forest. - Between Pto Frances and V. Colonial, on the slopes of the valleys and on the ridges, common on the slopes of El Centinela (also observed by JoHow); V. Colonial, not uncommon (also observed by JoHOw); C. Salsipuedes, ascending to $500 \mathrm{~m}$ (Al.-unr. fr. ${ }^{8} / 12$ I6, no. 71); La Vaquería, dry slopes; between Villagra and Pta Larga, scattered in the steppe-like vegetation (fl.-unr. fr. $7 / 1$ I7, no. 233).

Area of distribution: Perú; Central and South Chile; Argentina (Prov. Buenos Aires); Patagonia. The subsp. digynus endemic in Masatierra.

\section{Acaena L.}

66. A. masafuerana Bitter Bibl. Bot. 74 (I9I I) 45. - Fig. IO.

Masafuera: Scattered in the fell-fields, forming small dense mats together with mosses and lichens. Between the Correspondencia Camp and Las Torres, II $30-1370 \mathrm{~m}$ (fl.-fr. ${ }^{14} / 2$ I 7 , no. 395); edge of west precipice above Buque Varado, c. I $230 \mathrm{~m}$; C. del Barril, II IO-I $360 \mathrm{~m}$ (fr. $1 / 3$ I7, no. 539); Los Inocentes, from $1125 \mathrm{~m}$ to near the summit (fr. ${ }^{9 / 3} 17$, no. 380 ).

Sterile specimens were brought by the writer in 1908 and described by Professor BITTER. The new material was again studied by him, and he gives the following account of it.

"Procumbens vel parum ascendens, caespitosa, caudex cr. $2-4 \mathrm{~mm}$ crasșus, in radicem sat longam ramosam exiens, in ramos complures \pm ve divaricantes partitus; rami inter muscos et gramina repentes, breves, \pm ve congesti vel longiores cr. 4--I I cm longi, infra vaginis fuscescentibus subnitidis foliorum emortuorum densiusculis obtecti, apice foliis adhuc vigentibus subrosulantibus instructi; folia parva, cr. $\mathrm{I}_{\mathbf{2}}-4 \mathrm{~cm}$ longa; vaginae rufo-fuscescentes, nitidae, 
usque ad Io: $3 \mathrm{~mm}$, utrinque glabrae (etiam in margine); stipulae frondosae, lanceolatae, acutae, simplices vel vix dentatae, rarius manifeste I-dentatae, cr. I -2:0,5-I mm, glabrae vel prope apicem pilis parvis tenuibus marginalibus nonnullis instructae; petiolus plerumque brevissimus, cr. $2-3 \mathrm{~mm}$; rarius ad $8 \mathrm{~mm}$ longus, glaber; costa mediana subtus glabra vel parce pilosa; lamina 6-24:4-I2 $\mathrm{mm}$, plerumque 7 (rarius 9)-foliolata; foliola obovata, obtusa (inferiora nonnumquain acutiuscula), plana vel margine paulum revoluta, crenati-dentata, supra sordide viridia, fere glabra, ad dentium apices versus tantum in venis ordinis
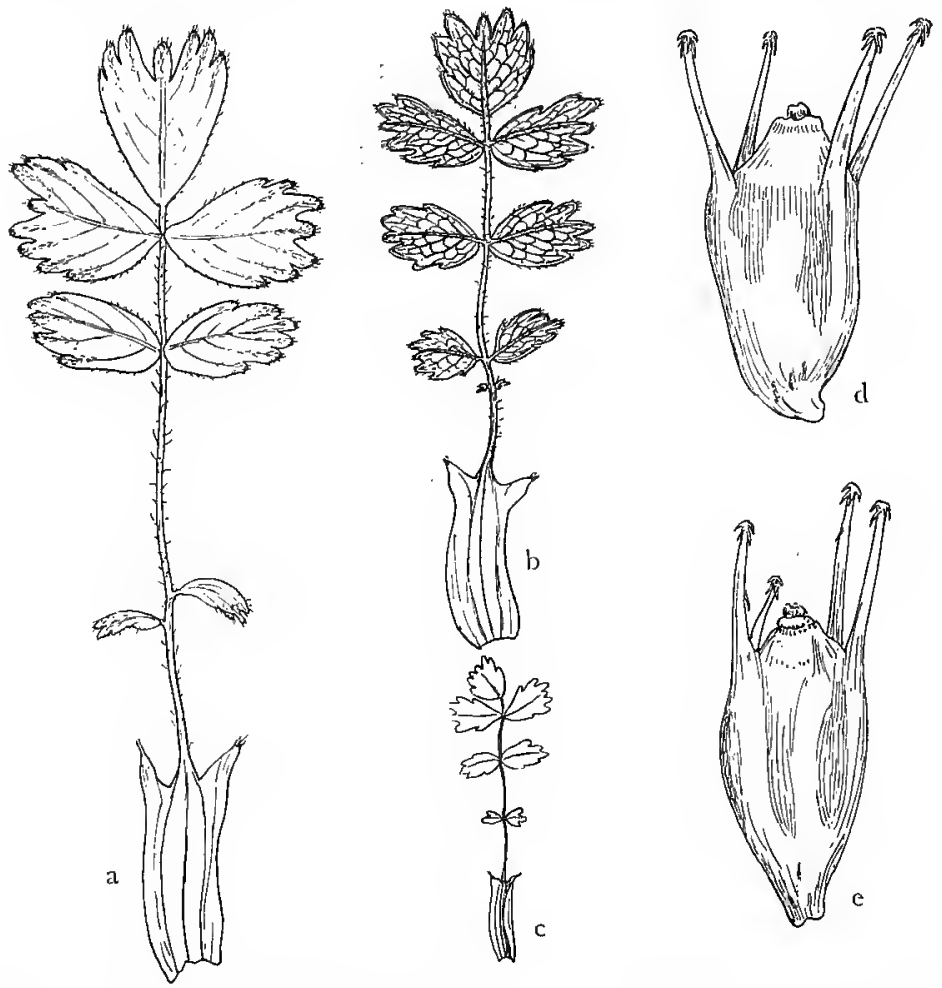

Fig. Io. Acaena masafuerana: leaves, a upper side, $\times 3, \mathrm{~b}$ lower side $\times 3$, c nat. size; d, e aclienes, $\times 18$.

secundi manifeste albide pilosa, subtus paulum glaucescentia, in venis primariis secundariisque dense pilosa vel solum in vena media appresse sericeo-pilosa, dentes margine et apice dense breviter pilosi; stipulae et foliolorum dentes in pagina superiore in hydathodam rubescentem exeuntes; paris supremi foliola sessilia, $2,5: \mathrm{I}, 4$ usque ad $7: 4 \mathrm{~mm}, 5-8$ dentata; foliolum terminale breviter petiolulatum (cr. $0,5-\mathrm{I}, 5$, rarius $-3 \mathrm{~mm}$ ), cr. $2: 2$ usque ad $6: 5 \mathrm{~mm}, 5-9$ dentatum, dens apicalis lateralibus manifeste minor, quam ob rem foliolum terminale lateralibus obtusius; scapus in parte inferiore foliis $I-2$ approximatis reductis instructus, ceterum nudus, vel rarius fere medio vel paulum infra capitulum folio valde reducto praeditus, in statu fructifero $6,5-I I, 5 \mathrm{~cm}$ longus, gracilis, in parte basilari ascendens, ceterum rectus, viridis vel purpurei-suffusus, 
glaber; capitulum terminale parvum, cr. 3-(tandem) $5 \mathrm{~mm}$ diam.; bracteae oblanceolatae, ad basim versus angustatae, apice obtusae, basi glabrae vel pilis acutis perpaucis et capillo pluricellulari uno alterove praeditae, fere a medio in margine pilis tenuibus unicellularibus acutis sensim densioribus instructae, capilli pluricellulares (articulati), aurei-rufescentes vel partim purpurascentes praecipue inter bracteas cupulasque dense aggregati; cupula obovoidei-obconica, turbinatisubtetragona, cr. I $\mathrm{mm}$ longa, $0,5 \mathrm{~mm}$ diam., fere glabra, capillo pluricellulari aurei-rufescente uno alterove valde sparso obsita, infra calycem in aculeos 4 breves primo fere I $\mathrm{mm}$ longos apice glochidibus $4-6$ parvis paulum inaequilongis armatos exiens; sepala 4 , cr. $0,8: 0,3-0,4 \mathrm{~mm}$, late elliptica, obtusa, apice intus dense breviter papillosa, ceterum glabra; stamina 2, parva, sepalis breviora; filamenta gracilia, $0,4-0,5 \mathrm{~mm}$ longa; antherae reniformes, utrinque emarginatae, cr. $0,17 \mathrm{~mm}$ longae, $0,3 \mathrm{~mm}$ latae; stylus $\mathrm{cr}$. $0,5 \mathrm{~mm}$ longus, stigma purpureum, subpatelliforme, plumosi-flabellatum, diam. $0,8 \mathrm{~mm}$; cupula in statu fructifero $\mathrm{I}, 5$ $\mathrm{mm}$ longa, I $\mathrm{mm}$ diam., aculeis porrectis purpurascenter suffusis I-I,5 $\mathrm{mm}$ longis.

Die Belege unterscheiden sich hinsichtlich der Farbe und Behaarung der Blättchen-Uaterseite etwas von einander: Nr. 380 ist unterseits kaum grau, mehr blassgrün, die Behaarung ist unterseits fast ausschliesslich auf die Mittelader beschränkt, Nr. 395 ist ähnlich, zeigt aber auch auf den Seitenadern I. Ordnung unterseits meist ziemlich deutliche Behaarung, Nr. 539 dagegen ist unterseits ausgeprägt graugrün (ob infolge der bei dieser Form stärker als bei den andern beiden Nummern ausgeprägten Papillosität der Unterseite?), ausserdem sind Mitteladern und Seitenadern I. Ordn., teilweise sogar die II. Ordn. dicht mit anliegenden spitzen Haaren bedeckt.

Diese Art, von der Skot'ssberg von seiner ersten Reise nach Juan Fernandez nur blüten. und fruchtlose Zweige heimgebracht hatte, wurde von mir in meiner Gesamtschrift über die Gattung (Biblioth. botan. Heft 74, S. 75) zweifelnd zur Sect. III Subtuspapillosae Bitt. gestellt, zu der die südchilenische A. pumila Vahl und die nur auf den beiden hawaiischen Inseln Maui und Kauai vorkommende $A$. exigua A. Gray gehört. Dass sich $A$. masafuerana von diesen bejden Arten erheblich unterscheide, betonte ich schon damals und wies auch auf ihre Übereinstimmung in Tracht und Behaarung mit verschiedenen Angehörigen der Section V Acrobyssinoideae hin. Die schönen, vollständigen Belege von SkotTsberG's zweiter Reise liessen leicht feststellen, dass diese auf Masafuera endemische Art besonders an den Blüten- und Fruchtorganen sämtliche für die Section Acrobyssinoideae bezeichnenden Merkmale besitzt: Blüten in einem endständigen kugeligen Köpfchen vereinigt; mehrzellige (gegliederte) goldbraune bis purpurne Haare reichlich zwischen den Brakteen und am Grunde der Cupulae; Cupula 4-kantig-kreiselförmig mit nur 4 in einer Ebene nahe unter dem Kelche stehenden Stacheln, die nur an der Spitze mit einigen (4-6) Widerhaken (Glochiden) ausgerïstet sind.

A. masafuerana steht $\operatorname{der} A$. antarctica Hook. f. (Feuerland und westl. Magellansgebiet) und $A$. microcephala Schlchtdl. (Süd-Chile) nahe, sie unterscheidet sich von der ersteren durch die viel schwächere, niemals gelbliche Behaarung der Blätter und durch das Vorhandensein von I-2 kleinen Blätterı am Blütenstandstiel (scapus), von $A$. microcephala durch erheblich kleinere Blättchen mit weniger Randzähnen. 
Im Mesophyll der Blattscheiden von 4 . masafuerana sind die reihenförmig angeordneten Drusen aus Calciumoxalat, wie sie in meiner Gesamtdarstellung: Biblioth. botan. Heft 74, S. 62, Fig. Io für A. lucida Vahl abgebildet sind, besonders schön zu sehen.»

Area of distribution: Endemic in Masafuera.

67. A. ovalifolia Ruiz et Pav. subsp. australis Bitt. 1. c. 239; SkotTsBERG, Stud. 9.

Masatierra: On both sides of the Portezuelo ridge, on the north side from $250 \mathrm{~m}$ in the maqui-thickets (fl. $3 / 12 \mathrm{I} 6$, no. 35), on the south side scattered from near the pass (fl.-fr. ${ }^{15} / 1216$, no. 35 b) down to Villagra, in the forest near the road.

The var. microphylla Phil. in sched. Herb. Santiago (and Berlin, see BitTER l. c. 238) is most likely the same that I have collected. PHILIPPI's plants were sterile. Professor BITTER remarks to my specimens that he cannot distinguish them from subsp. australis Bitt.

var. insulae-exterioris Bitt. 1. c. 245 .

Masafuera: Q. del Mono, in the forest c. $450 \mathrm{~m}$ (fl.-fr. $12 / 217$, no. 46o); Q. de las Casas, in the gorge ( $\mathrm{fr}^{11} / 2{ }^{17}$, no. 440); $Q$. de las Vacas, outer part; $Q$. de la Lobería; near the Correspondencia Camp, $1100 \mathrm{~m}(\mathrm{fl} .5 / 3 \mathrm{I} 7$, no. 372); Las Torres, $1370 \mathrm{~m}$ (if the same form as no. $373^{\text {?) }}$; C. del Barril, $985 \mathrm{~m}$; ridge between $Q$. Inocentes and $Q$. Angosta, c. I IOO m; near Las Torres, I350 m $(5 / 3$ I7, no. 373 , a compact form, apparently not the same as the rest, see below).

Professor BITTER kindly remarks to my collection: „Der var. insulaeexterioris Bitt. entspricht n. 400 . Nicht nennenswert verschieden ist $n$. 460 (das eine Exemplar zeigt an den Nebenblättern hie und da ein undeutliches Seitenzähnchen, also Übergang zu den verbreiteteren Formen dieser Art). Die Hoch. landsform n. 372 unterscheidet sich von den beiden vorhergenannten Belegen durch auch an den älteren Blättern bleibende dichtere seidig.glänzende Behaarung der Blattunterseite und kompakteren Wuchs der aufrechten, die Blütenstände entwickelnden Triebe. Die am höchsten wachsende Form, n. 373, entspricht der von SkOTTSBERG I908 zusammen mit $A$. masafuerana gesammelten Pflanze, mit dicht rasigem gestautem Wuchs, kleinen Blättern mit wenigen Blättchen und weniger Zähnchen daran, die bei BiTTER l. c. 245 ebenfalls ohne Blüten und Früchten dargestellt worden ist. Auf Grund der abweichenden Form ihrer Nebenblätter: meist jederseits mit einem Zahn sowie umgekehrt der erheblich geringen Zahl der Blättchenzähne (nur I3-I5) ist sie von der var. insulaeexterioris $\mathrm{zu}$ unterscheiden, aber wegen Mangel an Blüten und Früchten von ähnlichen Formen ausserhalb der Inseln nicht sicher zu sondern.»

Area of distribution: Subsp. australis from S. Chile to Fuegia and the Falkland Islands; the variety only known from Masafuera.

Acaena argentea Ruiz et Pav. $\times$ Margyricarpus setosus Ruiz et Pav. subsp. digynus Bitter. - Plate I3, fig. I.

On the open slopes of Masatierra I found a curious plant, which, in general habit as well as in morphological features seemed to stand between Margyri. 
carpus and Acaena argentea. The material was sent to Prof. BitTer, who, after a careful inspection, confirmed my view. He has established the new bastard genus Margyracaena, described below with full details.

Masatierra: El Pangal, west branch, dry ridge leading to C. Centinela, c. $250 \mathrm{~m}$, rare (no. 579); V. Colonial, barren ground along the road to Portezuelo before it enters the macal, one small patch mixed with $A$. argentea (no. 562; here the photograph on Plate I3 was taken); between the foot of Yunque and Villagra, $190 \mathrm{~m}(\mathrm{fl} .7 / 1 \mathrm{17}$, no. $24 \mathrm{I} \mathrm{b}) ; \mathrm{B}$. Villagra, rocky and sandy ridge near the camping place, c. $200 \mathrm{~m}$, several specimens (fl. $6 / 1 \mathrm{I} 7$, no. 24I).

Area of distribution: Originated in Masatierra, as a result of natural crosses between the native Margyricarpus and the introduced Acaena argentea.

Professor BITTER kindly communicated the following description:

»Margyracaena Skottsbergii Bitter nov. gen. et spec. hybr.

Suffruticosa; rami vegetativi robusti, $4-5 \mathrm{~mm}$ diam., decumbentes vel \pm ve horizontaliter explanati, in partibus vetustioribus lignosis reliquiis foliorum emortuorum, praecipue vaginis sordide fuscescentibus, \pm ve dense involuti, laxiuscule irregulariter ramosi; internodia brevia, plerumque $4-8 \mathrm{~mm}$, rarius $1 \mathrm{~cm}$ longa, in statu novello pilis tenuibus longis crebris obsita, serius \pm ve glabrescentia, cortice rubri-fusco tandem defoliante obtecta; foliorum vaginae cr. 6-10 mm longae, $7-8 \mathrm{~mm}$ latae, subamplexicaules, viridi- vel tandem rubri-fuscescentes, extus pilis longis tenuibus densis subsericei-strigosae, intus flavi-fuscescentes et parcius pilis longis obsitae, apice in stipulas anguste lineari-lanceolatas longe acuminatas acutas simplices vel 2 -fidas $7-8 \mathrm{~mm}$ longas $2-3 \mathrm{~mm}$ latas frondosas in vaginarum marginibus decurrentes exeuntes; petiolus fere nullus; lamina imparipinnata, 5-(plerumque)7-juga; interstitia brevia, 1-3 $\mathrm{mm}$ longa, rhachis ergo $15-20 \mathrm{~mm}$ tantum longa, utrinque dense subsericei-pilosa; foliola inferiora lineari-lanceolata, longe acuminata, simplicia vel dentibus paucis incisa, $6-9: 1-2$ $\mathrm{mm}$, superiora sensim majora, lanceolata, lateralia basi obliqua, sessilia, infra medium latissima, ad apicem versus sensim acuminata, acuta, $18-20: 3-4 \mathrm{~mm}$, dentibus in utroque latere $2-3$ acutis incisa, foliolum terminale petiolulo $2 \mathrm{~mm}$ longo suffultum utrinque sensim angustatum fere medio latissimum cr. $18: 3 \mathrm{~mm}$, dentibus utrinque $2-3$ (raro 4 ); inter foliola majora praecipue in rhachidis parte superiore foliola minuta nonnulla $(3-4)$ interjecta $(1-2,5 \mathrm{~mm}$ longa, $0,5-0,7 \mathrm{~mm}$ lata) adsunt; foliola omnia subcoriacea, margine revoluta, supra nitida, praeter glandulas minutas breviter stipitatas (microscopice tantum perspiciendas) valde sparsas (densiores in venae mediae parte inferiore tantum) glabra, subtus pilis tenuibus longis albidis densiuscule sericei-villosa, venis supra impressis, subtus fere solum vena media prominente; rami floriferi erecti, breves, cr. $5-8 \mathrm{~cm}$ longi, foliis sensim minoribus; inflorescentiae minores pauciflorae in foliorum superiorum axillis, terminalis globosa, diam. cr. $12 \mathrm{~mm}$, in Acaenae modum e floribus densis congestis composita, in scapum brevem $\mathrm{I}-2 \mathrm{~cm}$ tantum longum evecta; bracteae lineares, $2-4 \mathrm{~mm}$ longae, acutae, in marginibus pilis tenuibus longis densis instructae, minores $\mathrm{I}-2 \mathrm{~mm}$ tantum longae, ceterum similes; cupula obconica, dense villosa, immatura a me visa cr. $3: 2 \mathrm{~mm}$, infra calycem in aculeos $4(-5)$ breves inaequilongos $2-4 \mathrm{~mm}$, glabros (etiam apice!, 
glochidibus ergo omnino destitutos) vel rarius pilis tenuibus longis paucis prope basim (sicut cupula) obsitos rubri-suffusos exiens; sepala $4-5$, lanceolata, utrinque angustata, acuta, $2-3:$ I $\mathrm{mm}$, extus dense sericei-villosa, intus viridia, glabra, subnitida; stamina 3, filamenta gracilia, 4-6 $\mathrm{mm}$ longa; antherae reniformes, utrinque emarginatae, $0,8-\mathrm{I} \mathrm{mm}$ longae et latae, purpureae; carpellum 1, rarius 2; styli fere $I, 5 \mathrm{~mm}$ longi, graciles; stigmata $2-2,5 \mathrm{~mm}$ longa, $I, 5 \mathrm{~mm}$ diam., bilateraliter plumosi-flabelliformia, verisimiliter albida.

Es ist bemerkenswert, dass SKOTTSBERG diese Pflanze an vier verschiedenen Oertlichkeiten auf Masatierra und zwar stets in Gesellschaft von Acaena argentea und Margyricarpus gefunden hat. Danach scheint sich dieser Bastard leicht zu bilden, wozu die ausgesprochene Windbestäubung der beiden mit einander vergesellschafteten Eltern reichlich Gelegenheit bieten mag. ${ }^{1}$

Der Beschreibung liegt hauptsächlich Nr. $24 \mathrm{I} \mathrm{zu} \mathrm{Grunde,} \mathrm{da} \mathrm{nur} \mathrm{an} \mathrm{ihr}$ Blütenstände gefunden worden sind; bei Nr. 562 und 579 traf SkOTTSBERG nur vegetative Triebe an, so dass die Blütenorgane der einzelnen gesondert entstandenen Kreuzungen nicht verglichen werden konnten. In der Ausbildung der vegetativen Organe bestehen kaum nennenswerte Unterschiede: die Zahl der Fiederpaare scheint bei Nr. 24I häufiger 7 zu sein als bei den andern beiden hauptsächlich mit 5-6-jochigen Blättern versehenen Nummern, doch habe ich auch bei ihnen 7-jochige Spreiten gesehen. Die Blättchen sind bei 24 I wohl durchgängig etwas grösser und breiter als bei 562 und 579 (bei letzteren messen die obersten Blättchen nur I4- I6:3 mm), doch könnte dieser geringe Unterschied auch durch Standorts- und Ernährungsverhältnisse hervorgerufen worden sein.

In der Form und Grösse der Blätter und ihrer Teilung nimmt Margyracaena deutlich die Mitte zwischen Acaena und Margyricarpus ein: Verhältnis der Länge der Blattspreiten $z u$ ihrer Breite bei

Acaena (4-)5-8,5:3,5-4 (seltener 4,5) cm; Margyracaena $2,5-4,5: 1,5-2,5$ $\mathrm{cm}$; Margyricarpus I-I,7: I-I,5 cm.

Länge : Breite der Endblättchen bei: Acaena (I,8-)2,5-3:0,8-I cm; Margyracaena $\mathrm{I}, \mathrm{x}-\mathrm{I}, 8: 0,2-0,3 \mathrm{~cm} ;$ Margyricarpus $0,8: 0,05 \mathrm{~cm}$.

Die Blättchen von Margyracaena sind am Rande deutlicher umgerollt als bei der Acaena und weniger stark umgerollt als bei Margyricarpus.

Zahl der Zähne an den Endblättchen bei Acaena 2I-29, Margyracaena 5-7, Margyricarpus o.

Die unterseitige Bekleidung der Blättchen ist bei fast allen Varietäten der

${ }^{1}$ In meiner Acaena-Monographie, Biblioth. botail. Heft 74, S. 296-321, habe ich eingehend die leichte spontane Kreuzung unter den Acaenen in den botanischen Gärten beleuchtet: man beachte besonders die Bastarde zwischen in der Tracht und in Fruchtbau einander ferner stehenden Arten wie $A$. glabra und $A$. sanguisorbae sowie wwischen $A$. glabra und $A$. Hieronymi. Meine seit Jahren bestehende Absicht, Kreuzung der Acaenen mit andern SanguisorbeenGattungen, z. B. mit Poterium spinosum, Polylepis, Bencomia herbeizuführen, hat sich bislang hauptsächlich wegen der Ungleichzeitigkeit der Blütenentwicklung nicht verwirklichen lassen. Hoffentlich gelingt es mir, zwischen einer vom chilenischen Festlande stammenden Forn der Acaena argentea und der (in Gegensatze zu der zweikarpelligen subsp. digynus von Masatierra) mit nur einem Fruchtblatte in jeder Cupula versehenen festländischen Unterart des Margyricarpus setosus, die ich beide lebend in PAege habe, eine der Masatierra-Margyracaena ähnliche Kreuzung zu erzielen. 
Acaena argentea (auch bei den auf Juan Fernandez vorkommenden Formen) dicht anliegend silberig seidenhaarig (mit sehr langen, dünnen, einzelligen Haaren), Margyracaena ist unterseits ebenfalls reichlich mit feinen, langen, anliegenden Haaren bedeckt, aber dieses Haarkleid ist sichtlich etwas lockerer: neben die weiss-silberige Unterseite von Acaena argentea gehalten zeigt die zwar immerhin noch etwas silberige Unterseite von Margyracaena einen deutlichen Stich ins Grünliche.

Die Blättchen von Margyricarpus sind unterseits frei vols einfachen, dünnen Langhaaren und daselbst auf der Mittelader mit winzigen gestielten Drüsenköpfchen versehen, die bei Margyracaena zerstreut an derselben Stelle ebenfalls vorkommen.

In der Tracht, besonders in der Form der Blätter erinnert Margyracaena mehr an die Gattung Acuena; in der Ausbildung der Bliitenorgane sind jedoch einige auffällige Merkmale hervorzuheben, die sich mit der Acaena-Selktion Ancistrum, zu der sie ihrem Äussern nach gehören müsste, nicht in Einklang bringen lassen, zunächst das völlige Fehlen von Glochiden, überhaupt jeglicher Behaarung an der Spitze der Cupularstacheln, ferner das wenn auch seltene Vorkommen von 2 Carpellen in einer Cupula. Auch durch das fast gänzliche Fehlen eines eigentlichen, gestreckten, das endständige Blütenköpfchen tragenden Schaftes weicht Margyracaena von den Ancistren ab.

Trotzdem dass reife Früchte von dieser merkwürdigen Pflanze nicht vorlagen, liess sich doch bereits aus der Untersuchung der an den Belegstücken vorhandenen verblühten Cupulae mit genügender Sicherheit ermitteln, dass hier tatsächlich, wie SkotTSBERG bereits beim Sammeln der Pflanze vermutet hatte, eine offenbar durch Kreuzung entstandene Zwischenform zwischen den beiden, am Fundorte mit einander vergesellschafteten Sanguisorbeen Acaena argentea $\mathrm{R}$. et $\mathrm{P}$. und Margyricarpus setosus $\mathrm{R}$. et P. subsp. digynus Bitt. vorliegt: zu beachten ist besonders, dass die an Acaena gemahnenden, bei Margyricarpus fehlenden Cupularstacheln bei Margyracaena von ungleicher Länge sind, offenbar stets kurz (nur 2--4 mm lang) bleibeıs und völlig der endständigen Widerhaken (Glochiden) ermangeln, während die Cupularstacheln von Acaena argentea $6-7 \mathrm{nmm}$ lang werden und an der Spitze stets mit 4-6 kräftigen Glochiden ausgerüstet sind.

Besondere Beachtung verdient übrigens, dass auch Margyricarpus setosus längs verlaufende hervortretende Kanten an den noch unreifen Früchten besitzt, die jede mit einigen niedrigen Höckern versehen sind; im reifen Zustande verschwinden jedoch diese Kanten mit ihren Höckern äusserlich vollständig, da die Cupula beerenähnlich fleischig wird und $\mathrm{zu}$ einem fast kugeligen Gebilde anschwillt; erst beim Trocknen treten die höckerigen Kanten infolge des starken Einschrumpfens der weicheren Cupularteile wieder deutlicher hervor.

Man wird vielleicht an der Cupula von Margyracaena Andeutungen von der im reifen Zustande etwas beerig saftigen, kugeligen Ausbildung der Cupula von Margyricarpus vermissen; ich betone jedoch, dass ich an lebenden Exem. plaren von Margyricarpus setosus erst kurz vor der völligen Reife die scheinbeerenähnliche Entwicklung der Cupula habe bemerken können. Da hier nur unreife, vielleicht wegen der aus zivei einander sehr fern stehenden Arten entstandenen Kreuzung niemals zu voller Entwicklung gelangende Früchte vor- 
liegen, so wird man nicht notgedrungen etwas von einer Annäherung an den Margyricarpus-Bau zu beobachten brauchen. ${ }^{1}$

Als Abweichung der Margyracaena von den beiden Eltern sind zu nennen 1) die oft etwas grössere Zahl der Fiederpaare an den Laubblättern: bei Margyricarpus 4-5, bei Acaena 5, seltener 6, bei Margyracaena 5-(meistens)7; 2) die tieferen Blättchenzähne der Margyracaena an allen Blättchen; Acaena argentea besitzt dagegen nur an den unteren Blättchen jeder Spreite etwas tjefere Sägezähne, an den oberen, voll ausgebildeten Blättchen ist sie nur kerbiggesägt, die Blattchen von Margyricarpus sind völlig ganzrandig. Offenbar hängt das stärkere Hervortreten der Sägezähne an den Margyracaena.Blättchen aber mit der im Vergleich zu Acaena argentea stärkeren Umrollung des Blattrandes zusaınmen, die als Erbstïck von Margyricarpus herrührt: die Randumrollung ist bei Margyracaena allerdings bedeutend schwächer als bei Margyricarpus; da sie aber an jedem Zahn von beiden Seiten her erfolgt, so erschemen die Zähne bei ihr etwas schmäler, länger und spitzer als bei der kaum oder gar nicht umgerollten $A$.argentea. - Ob die im Vergleich zu Acaena etwas grössere Zahl der Seitenfiedern der Margyracaena auf Rechnung des bei Bastarden oft zu beobachtenden ïppigeren Wachstums der vegetativen Teile zurïckzuführen ist, muss dahin gestellt bleiben.

Je länger ich mich mit dem Vergleiche der Margyracaena mit den beiden Elternarten beschäftigt habe, um so mehr sind meine anfänglichen Zweifel an ihrer Eutstehung behoben worden. Gerade in den er tscheidenden Punkten, der Ausbildung der Frulatifikationsorgane, dürte der Margyricarpus-Einschlag bei dem Gattungsbastard unverkennbar sein.»

\section{Leguminosae.}

\section{Sophora L.}

In Bot. Zeitung XIV (1856) 642 PHILIPPI described a Sophora, collected by GERMAIN in Masatierra, as Edzuadsia fernandeziana. In the same journal for 1873,743 , he added $E$. Reedeana from Masatierra and $E$. masafuerana from Masafuera. Of this he had only sterile material, the flowers, but not the fruit, being known in the other two.

Hemsley, 1. c. 32, and JoHow, Estud. 88, reduced all to S. tetraptera J. Mill., Ait.; still, PHLLIPPI had indicated a difference worthy of some attention,

1 Übrigens sei bei dieser Gelegenheit be\%üglich der bei Margyracaena trotz der wahrscheinlich stets tauben Früchte vorhandenen, zwar kleinen, aber doch deutlich ausgebildeten Cupularstacheln bemerkt, dass sich diese Organe nach meeinen Erfahrungen bei rein weiblichen Acaena.Pflanzen auch dann gut ausbilden, wenn die Blüten wegen Fellens männlicher Exemplare unbefruchtet bleiben und nachweislich taub sind, wovon 'ich mich seit Jabren an einer in botanischen Garten befindlichen, reich wuchernden und sich durch unterirdische Ausläufer vermehrenden weiblichen Pflanze von A. macrostemon subsp. pachystigma Bitt. (in Acaena Monograplie, Biblioth. botan. Heft 74 , S. 192) überzeugt habe. Auch rein weibliche, von männlichen und monoezischen Exemplaren völlig abgesonderte Pflanzen der Sanguisorbee Bencomia caudata bilden ihre kugeligen Fruchtcupulae gerade so aus als ob sie reife Samen enthielten. (Weitere Beispiele zu der in den letzten Jahrzehnten an versçhiedenen Pflanzen nachgewiesenen Erscheinung der Parthenocarpiel) 
for the petals in the species from Masatierra were described and figured with a distinctly longer nail than in the species from the continent or from New Zealand. In I908 I only got scanty material, but the Masafueran Sophora was found with pods. As these were smooth and entirely unwinged, I separated the island forms as subsp. fernandeziana (Phil.) from the ordinary S. tetraptera. This time I have a large material at hand, having also studied the collections in Santiago and Kew.

All plants from Juan Fernandez differ from Chilean or New Zealand Sophoras in the smaller number of leaflets, the smaller flowers, the longer nails of the petals, and in the unwinged pod. It is noteworthy that there is, in New Zealand, a species with small flowers, narrow-winged pod and only 2-4 pairs of leaflets, $S$. prostrata Buchan. In some respects, this comes nearer to the Juan Fernandez forms, but is, of course, quite distinct.

Of Philippi's species, Edw. masafnerana is easily distinguished, as seen from my description and figures. All specimens collected in Masafuera (GuAJARDO! - the type -, JOHOW! and the writer) are exactly like each other and rather unlike all forms from Masatierra. The difference between Edzv. Reedeana and fernandeziana appears to be slight. My figures were prepared from PhILIPPI's type material; they show a certain difference in the shape of the petals. PHILIPPI described the leaflets of fernandeziana as spathulate, but his figure ( $\mathrm{pl}$. VIII B) shows an almost elliptical leaflet; comp. also my fig. I 2 a, $l$. Unfortunately, none of my specimens are in flower, what makes the identification with PHILIPPI's forms uncertain. No, 322 from Pto Ingles has 8-I4 pairs of narrow elliptical leaflets, densely villous with reddish or silvery hairs, indicating that they were not fully developed. The same form was collected by BERTERO (no. I516! Herb. Kew); here the leaflets have attained full size and show a tendency to become slightly spathulate. I believe I am right in bringing these to fernandesiana.

No. 599 from Vaquería, also found in Q. Juanango, where mature pods were gathered, is a robust form with 8-Io pairs of large leaflets (13-14 $\times 5-8 \mathrm{~mm}$ ). I bring this to Reedeana. Seeds were sown in the Gothenburg Garden in I9I8, but the plants are still (Sept. 192I) rather weak and differ from the parents in being nearly glabrous, probably a direct result of greenhouse life. Nos. 63 and especially 2 I4 differ from the former by their very slender twigs; the leaflets are broader, perfectly glabrous above and with few hairs below; there are 8- Io pairs in no. 63 (size $8-\mathrm{IO} \times 5 \mathrm{~mm}$ ) and $6-8$ pairs in no. 214 (size $6-8 \times 4-5 \mathrm{~mm}$ ). Both are sterile. I distinguish these plants as f. gracilior. With regard to the marked variation in the Masatierran Sophoras, I for the present comprise all forms under the specific name fernandeziana. S. Reedeana is retained as a variety, so that it be not forgotten. A definite arrangement can be made only after an examination of a larger material, with flowers and pods of all the forms.

Finally, I shall say a few words about the Sophoras of Chile and of New Zealand. S. tetraptera occurs in the latter place in two distinct forms or species, S. grandiflora (Salisb.) and microphylla Ait. No specimen from Chile that I have come across matches $S$. microphylla, but all are very like S.grandiflora in most respects. As a rule, the leaflets number $10-20$ pairs in both, they may be a trifle broader and more oval in the Chilean plant, but this is 
hardly a reliable character. The standard is more orbicular in the latter, if always, I cannot tell, and the flower smaller. PHILIPPI tried to find some difference in the calyx, but without much success (comp. my figures $\mathrm{I} 2 \mathrm{~d}$, e and.g). The seeds of the Chilean plant are ellipsoidal, slightly compressed from the sides, castaneous, $6-7 \mathrm{~mm}$ long and $4-4,5 \mathrm{~mm}$ broad. I have not seen the seeds of $S$. grandiflora; in microphylla I found them dirty yellow or yellowish brown, see plate 20, fig. 3-4. For comparison also the seeds of S. toromiro (Phil.) Skottsb. were figured, differing from those of all the others in colour, size and shape.
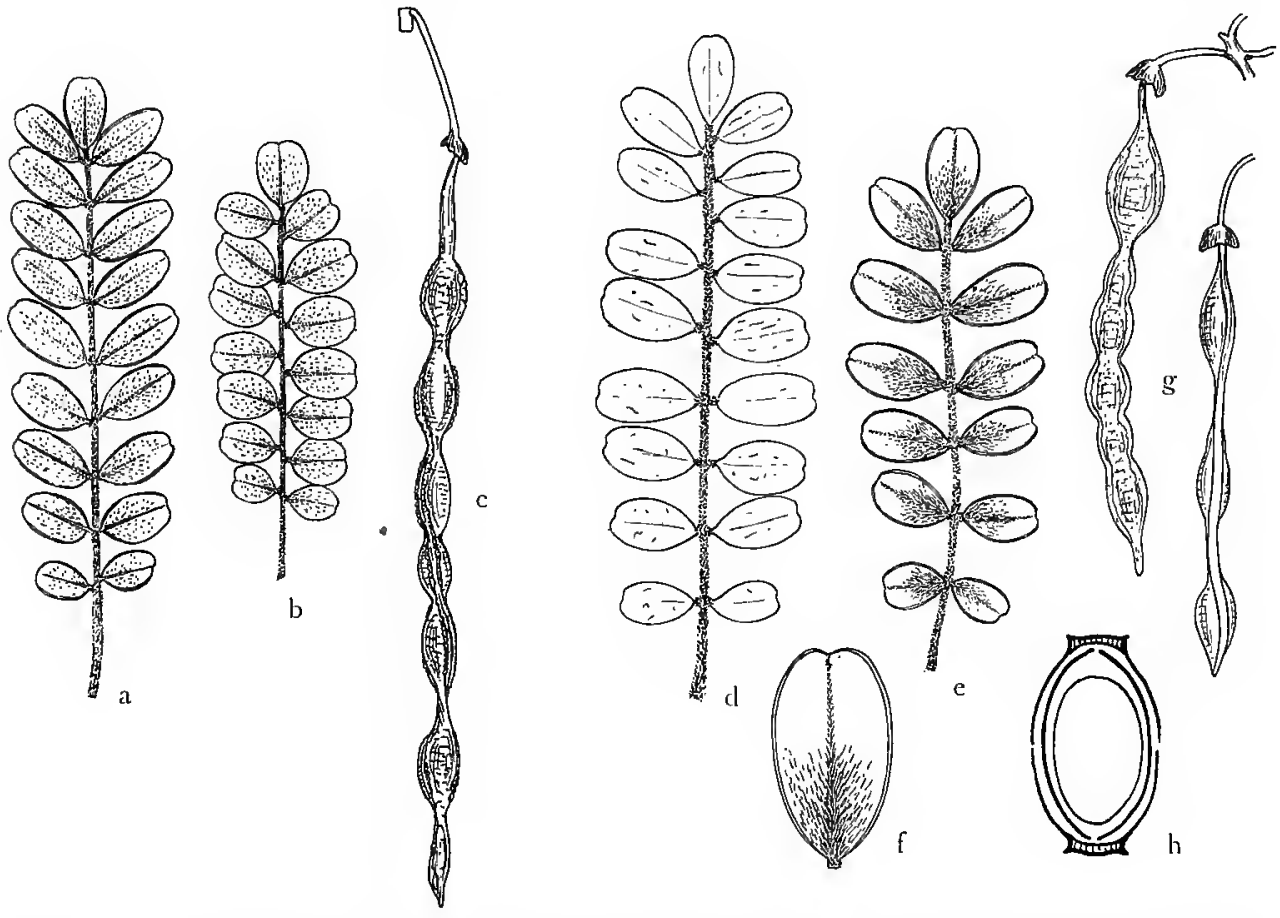

Fig. I1. a-c Sophora fernandeziana: a leaf of no. 63, lower side, b of no. 2 I4 (f. gracilior), nat. size; c mature pod of no. $599, \frac{1}{2}$ nat. size. d-g S. masafuerana." d upper, e lower side of leaf, nat. size, $f$ lower side of leaflet, $\times 2 ; \mathrm{g}$ mature pods, $\frac{1}{2}$ nat. size. $\mathrm{h}$ dehiscence of Sophora pod, schematic cross section.

We cannot, I think, simply use the name $S$. tetraptera for the Chilean plant. Philippi called it Edze. macnabiana Grah. Edinb. New Phil. Journ. 26 (I839) Ig6 (figured in Bot. Magaz. 66, pl. 3735). GRAHAM's description was based on a tree cultivated in the botanic garden of Edinburgh; it is not stated where the seeds came from. The main difference between this and the New Zealand plant was that the former "flowered when in full leaf» and was more hardy. I have seen Sophora in flower in some places in south Chile. The leaves are generally, but not always, shed before the flowers open, and the new foliage gets developed with the fruit. - I cannot find that Edze. cassioides Phil. is different.

The pod of Sophora has an interesting structure. Chesseman, Manual I22, 
writes under Sophora: "pod... indehiscent or 2-valved, each seed enclosed in a separate cell», and, under S. tetraptera: "valves hardly dehiscent». I have seen opened pods in several species; a diagrammatic section is given in fig. $\mathbf{l}$, h.

\section{S. fernandeziana (Phil.) Skottsb. - Fig. I2 a.}

Arbor plurimetralis robusta, cortice obscuro cinereo-fusco sat tenui parum striato, vetusto quasi squamoso. Folia $6-8 \mathrm{~cm}$ longa, thachide sat dense rufovel cinereohirsuta paulo complanata et sulcatula; foliola 8-12(-14) paria, elliptica vel elliptico lanceolata, basi et apice obtusa, interdum minute emarginata, $8-\mathrm{I} 2(-\mathrm{I} 5) \mathrm{mm}$ longa et $3.5-4(-6)$ lata, obscure viridia, subtus pallidiora, supra pilis brevibus cinereis vel rufescentibus inspersa, subtus magis sericea, serius utrinque glabrata. Flores quam in S. tetraptera e Novozelandia orta minores, sec. specimina Philippiana a cl. Germaln lecta infra depicti. Calyx obliquus, $10 \mathrm{~mm}$ diam. et ad $13 \mathrm{~mm}$ longus, dense rufosericeus. Vexillum late ovatum, acutatum, limbo $27 \mathrm{~mm}$ longo et 20 lato, ungue cochleato et incrassato, $8 \mathrm{~mm}$ longo; alae leviter curvatae limbo ad $25 \mathrm{~mm}$ longo et $6 \mathrm{~mm}$ lato, ungue $7 \mathrm{~mm}$ longo. Carinae petala falcata, limbo $30 \mathrm{~mm}$ longo et $5 \frac{1}{2} \mathrm{~mm}$ lato, ungue ad $9 \mathrm{~mm}$. Stamina ad $30 \mathrm{~mm}$ longa, antheris linearibus, $2 \mathrm{~mm}$ longis. Ovarium sericeum circ. $2 \mathrm{~cm}$ longum leviter curvatum; stylus $1 \mathrm{~cm}$, glaber recurvus. Legumen immaturum in specim. nostris num. 322 2-6-locel. latum, exalatum. Philippi folia mox caduca solum vidit et illa glabriuscula dixit, sed in ejusdem typo foliola satis villosa sunt.

Masatierra: BER'TERo no. I5I6! GERMAIN! Scattered in the forest belt from near the sea level to a few hundred meters. - Pto Frances (Johow); Pto Ingles, central ridge, $380 \mathrm{~m}$ (unr. fr. ${ }^{19} / 1$ I 7 , no. 322). The following localities belong to this or to one of its forms: NE. slope of Damajuana, c. $450 \mathrm{~m} ; \mathrm{V}$. Colonial, Q. del Monte Maderugo, steep rocks, $390 \mathrm{~m}$.

var. Reedeana (Phil.) Skottsb. - Plate 2O, fig. I; text fig. I I c, I 2 b, I 3 b.

Foliola 8-II-paria, elliptica, obtusa, vulgo IO-I $2 \times 5-6 \mathrm{~mm}$, sed usque ad $17 \times 8 \mathrm{~mm}$ visa, utrinque, subtus praesertim, dense villosa. Flores sec. specimen Philippianum a cl. REED lectum solum descripti. Calyx ut in typo sed minus obliquus, ad I $\mathrm{mm}$ longus et $10-$ I I $\mathrm{mm}$ diam. Vexillum limbo suborbiculato, obtusissimo, $20 \mathrm{~mm}$ longo et 19 lato, ungue crasso lineari $6 \mathrm{~mm}$ longo. Alae limbo oblique lanceolato, basi subcordato, $2 \mathrm{I} \times 6,5 \mathrm{~mm}$, ungue $7 \mathrm{~mm}$ longo. Carinae petala minus falcata, limbo $24 \times 7,5 \mathrm{~mm}$, ungue $7 \mathrm{~mm}$. Stamina ad $28 \mathrm{~mm}$ longa, antheris anguste ovatis $2,5 \mathrm{~mm}$ longis, Ovarium ut in typo. Legumen maturum in specim. nostris 599 nec non 1238 inventum, magnum, durum, fuscum nec non pilosiusculum, ad $19.5 \mathrm{~cm}$ longum (pedicello $2,5 \mathrm{~cm}$ ), locellis ellipticis 9-10 mm longis compressis, alis destitutum sed anguste 4-limbatum. Semina pro genere magna, elliptica, compressa, $8 \mathrm{~mm}$ longa, $4-5$ lata et 3-4 crassa, castanea, nitidula.

Masatierra: REED! - La Vaquería, c. $250 \mathrm{~m}$, many large trees in the bottom of the valley in dry open forest (fr. ${ }^{9} / 4$ 17, no. 599); Q. del Juanango, c. $200 \mathrm{~m}$ (fr. $9 / 4$ I 7 , no. 1238 ).

f. gracilior n. f. ad int. - Fig. I I $a-b$, I3 a. -- Specimina sterilia foliis adultis solum visa; a ceteris differunt ramulis gracillimis nec non rhachide 

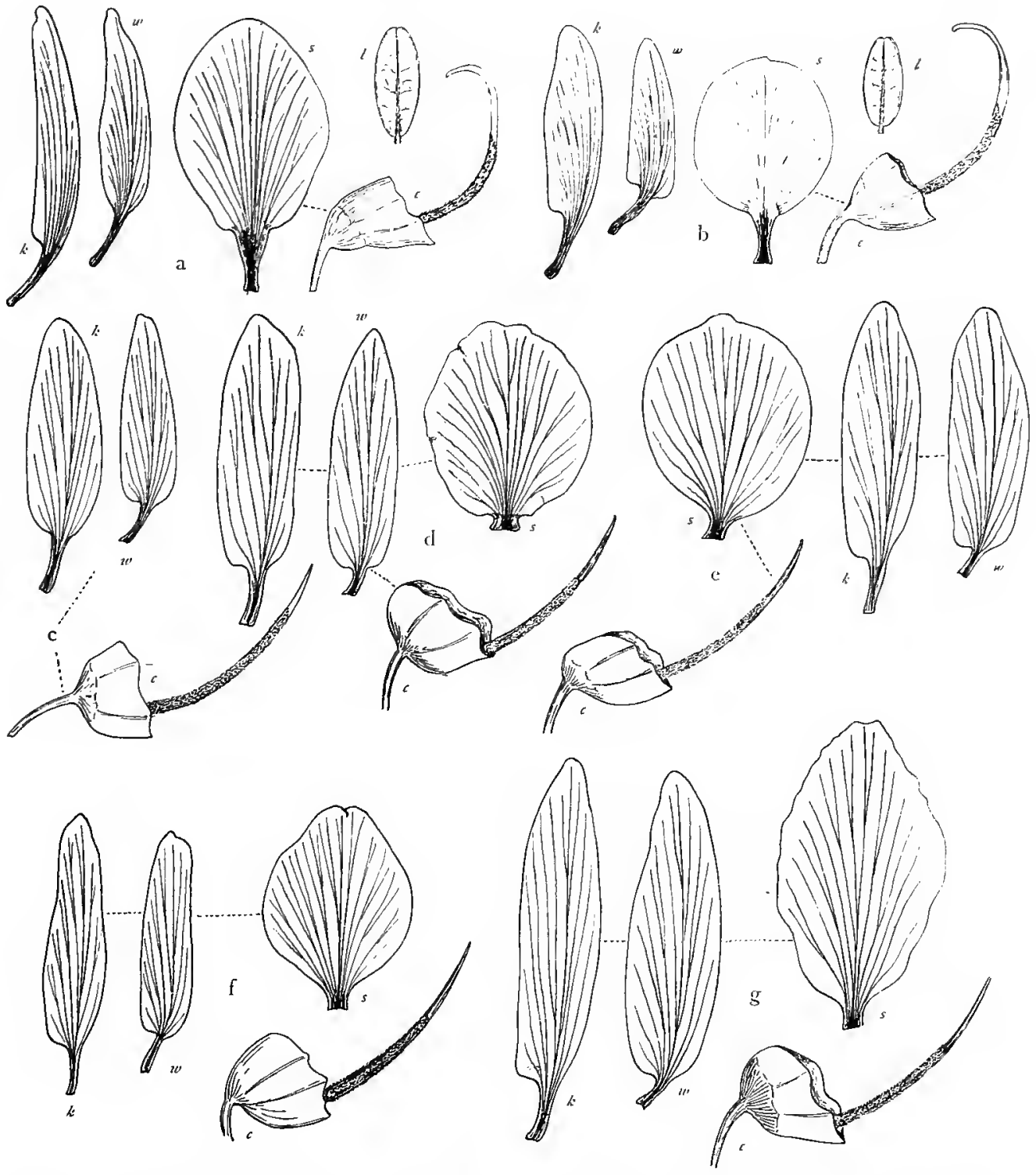

Fig. 12. Analysis of Sophora flowers: a S. fernandeziana orig. Germain; b S. Reedeana orig. REED; c $S$. masafuerana leg. JoHow (standard missing); d $S$. "tetraptera" from Chiloé leg. SkotTSBERg; e S. macnabianas from Valdivia, leg. Philippi; f S. microphylla and g S. grandiflora from New Zealand. All nat. size. $-k$ keel, $w$ wing, $s$ standard, $c$ calyx, $l$ leafler, lower side.

foliorum tenui; foliola ninora, pro longitudine latiora, glabriuscula. Folia 4-7 $\mathrm{cm}$ longa; foliola $6-8(-10)$-paria, suborbiculata-late elliptica obtusissima et emarginata, supra glabra, subtus hirsutula, $6-9 \times 3,5-6 \mathrm{~mm}$. Masatierra: $Q$. Damajuana, one tree near the stream, $250 \mathrm{~m}$ (no. 63) and higher up on the slope, $345 \mathrm{~m}$, a few trees (no. 214).

Area of distribution: Endemic in Masatierra. 
69. S. masafuerana (Phil.) Skottsb. - Plate 20, fig. 2; text fig. I I d-g, $12 \mathrm{C}, \mathrm{I} 3 \mathrm{C}$.

Arbor pumila paucimetralis ramis longis tenuibus subflexuosis cortice nigrescente. Folia $5-7 \mathrm{~cm}$ longa rhachide dense ac longe albo-villosa; foliola 6-10 paria, elliptica-subobovata, obtusissima saepe paulo emarginata, margine \pm revoluto, $8-12 \times 5-6 \mathrm{~mm}$, obscure viridia, subtus pallidiora, supra glabra, subtus inferne et secus medianum pilis albis longis patentibus dense vestita, ceterum parce pilosa et glabrescentia. Flores sec. specimen a cl. JoHOW lectum descripti. Calyx late campanulatus, $9 \mathrm{~mm}$ longus, ad $\mathrm{I} 3 \mathrm{~mm}$ diam., obsolete 5 -dentatus, fulvosericeus. Vexillum non visum. Alae ovato-lanceolatae, limbo $24 \times 8 \mathrm{~mm}$, ungue $6 \mathrm{~mm}$; carinae petala anguste ovata, subobliqua, limbo $28 \times 10$, ungue $7 \mathrm{~mm}$. Stamina ad $26 \mathrm{~mm}$ longa, antheris anguste ovatis $1,5 \mathrm{~mm}$ longis. Ovarium dense albolanatum ad $22 \mathrm{~mm}$ longum; stylus subrectus glaber, $8 \mathrm{~mm}$ longus. Legumen maturum $8-$ I I $\mathrm{cm}$ solum longum, irregulariter $3-7$ locel.

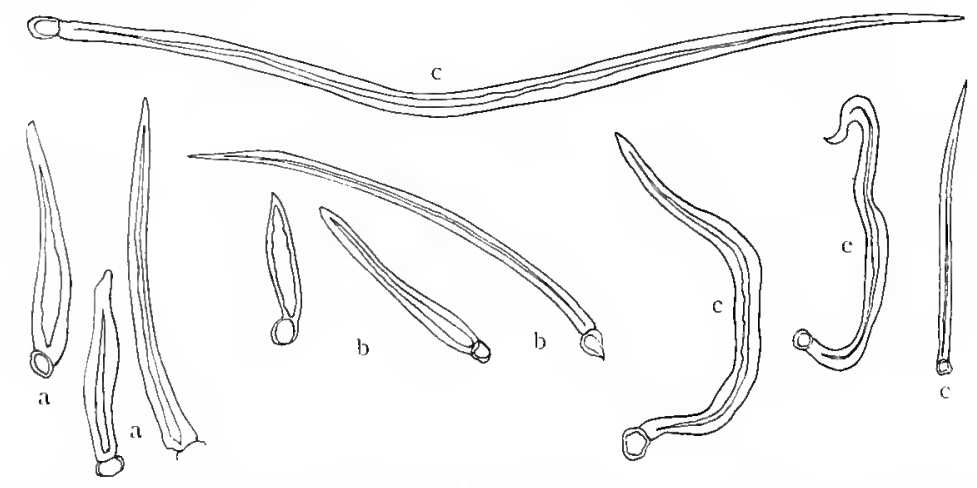

Fig. I3. Hairs from leaves of a Sophora fernandeziana (no. 214), b var. Reedeana (no. 599), c S. masafuerana; much enlarged.

latum, locellis 8-Io $\mathrm{mm}$ diam., obscure fuscum, albopilosum, omnino exalatum, marginibus laevibus vel paulo tuberculatis. Semina haud compressa, obscure castanea--flavescentia, 6-7 $\mathrm{mm}$ longa et 4-6 $\mathrm{mm}$ crassa.

Masafuera: GuAJARDo! JoHOw! - Q. de las Casas, on shelves along the walls of the gorge (fr. ${ }^{11 / 2}$ I7, no. 504); Q. de las Vacas (JoHOW); Q. Angosta; Q. del Varadero.

This differs from all other forms in the pubescence of the leaflets, illustrated above; part of the hairs are longer and more crisp than in S. fernandeziana, as Fig. I 3 shows. There is also considerable difference in the flower and, still more so, in the pod. Besides the characters given the smooth surface of the pod and the thinness of its walls are to be remembered. The wings, of which there is a vestige in the former, are quite wanting or, at most, represented by an irregular row of tubercles. The variation in the colour of the seed should be noted.

JoHow says that he found a form of Sophora in Masafuera differing from PhILIPPI's species, but his material certainly belongs to the latter.

Area of distribution: Endemic in Masafuera. 


\section{Rutaceae.}

\section{Fagara L.}

70. F. mayu (Bert., Hook. et Arn.) Engler. - JoHow, Estud, 105. Fig. I4 a-d.

Masatierra: The largest forest tree and one of the commonest, ranging from Pto Frances to $Q$. Juanango and Co Chumacera and from about $200 \mathrm{~m}$ (or less) to more than $600 \mathrm{~m}$ (unr. fr. Dec. I9I6, no. I94; buds $11 / 4$ I7, no. 6I7; male fl. $18 / 8 \mathrm{I} 7$, no. $6 \mathrm{I} 7 \mathrm{~b}$, leg. K. BÄCKSTRÖM).

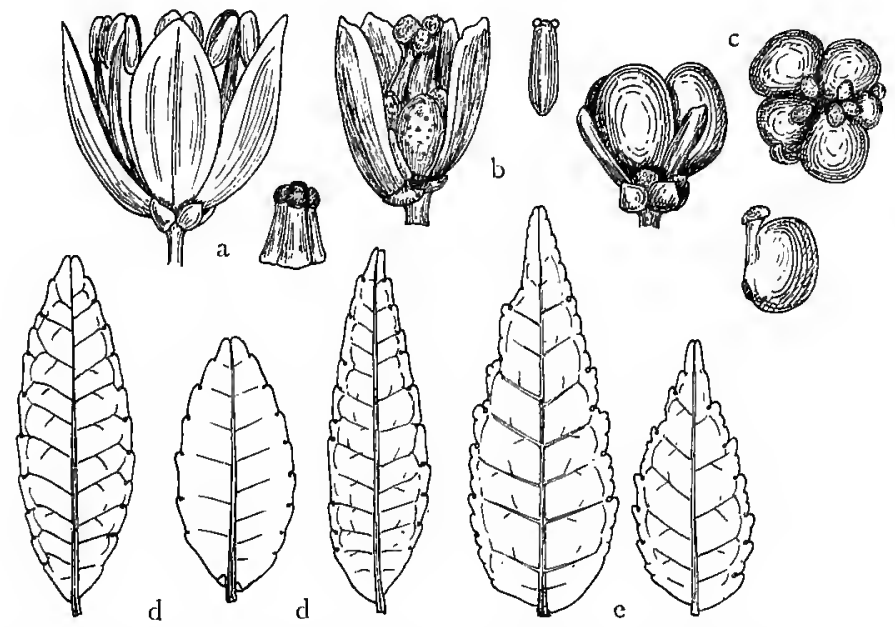

Fig. I4. a-d Fagara mayu; a o flower with gynaeceum, b of flower (one petal removed) with staminode, $\mathbf{c} ?$ in fruit, lateral and apical view, and one carpel, all $\times 5$; $d$ three leaflets, the central from the lower surface; e $F$. externa, two leaflets. d-e nat. size.

Leaves to I6 $\mathrm{cm}$ long, $3-7$ paired; leaflets $25-43 \times$ I I-i $3 \mathrm{~mm}$, elliptical-lanceolate, faintly or not acuminate, base cuneate, short petiolate; glands between the marginal teeth distinct but otherwise few or at least few pellucid ones. Margin of leaflet forming a regular arch; the teeth only 7 to 9 on each side and mostly all of the same width.

Area of distribution: Endemic in Masatierra.

*7I. F. externa nov. spec. - Fig. I4 e.

A F. mayu insulae Masatierrae incola praecipue differt foliorum fabrica. Folia ad I9 cm longa, 5-8 paria; foliola subsessilia, ovato-elliptica, basj late rotundata, sat longe et distincte acuminata, $25-48 \times$ I $3-15 \mathrm{~mm}$, margine dentibus inaequalibus utroque latere ad 20 vel ultra sat irregulariter undulatoserrata, punctis pellucidis creberrimis conspersa. Planta foeminea fructifera solum lecta. Fructus maturus irregulariter tuberculato-rugosus; carpella omnia quinque saepe fertilia. Semina subglobosa, nitida, atropurpurea. 
Masafuera: Forest on the Sanchez plain, $515 \mathrm{~m}$; Q. del Mono, c. $475 \mathrm{~m}$ (fr. ${ }^{20} / 2$ I7, no. $52 \mathrm{I}$ ); Q. del Blindado, $440 \mathrm{~m}$, not uncommon; $Q$. de la Loberia, $280 \mathrm{in}$, solitary trees.

Unfortunately, I did not pay sufficient attention to this form while in Masafuera. Back again in Masatierra, I began to realize that the "mayu" in the other island was different. I do not remember having seen any very large trees in Masafuera. Of $F$. mayu $\mathrm{I}$ have seen the specimens collected by BERTERO, Cuming, Moseley and Philippi, and all agree perfectly well with each other. In JoHOw's herbarium specimens from Masafuera were missing. This is much to be regretted, as a comparison would have been quite useful. I have figured the flowers of $F$. mayu; those of $F$. externa are unknown, but there is little or no difference in the fruit and seeds. Still, the leaves are so different that I have ventured to create a new species.

Area of distribution: Endemic in Masafuera.

Euphorbiaceae.

\section{Dysopsis Baill.}

72. D. glechomoides (Rich.) Müll. Arg. subsp. hirsuta Müll. Arg. JoHow, Estud. IO3.

Masatierra: The commonest herb of the dark, humid forests, thriving in very shady corners where few other species grow and sometimes carpeting the soil for many square meters. Pto Frances (also observed by JoHow), primeval forest, c. $500 \mathrm{~m}$; forests of the Yunque, very common about $500 \mathrm{~m}$; V. Colonial, Q. Gutierrez, c. $350 \mathrm{~m}$ (fl.-fr. $7 / 12$ I6, no. 42); steep slopes near Portezuelo (also JoHow), $450-600 \mathrm{~m}$, cominon (f.. fr. ${ }^{24} / 12 \mathrm{I} 6-^{31} / 7 \mathrm{I} 7$, no. $42 \mathrm{~b}$ ); Q. Seca, $435 \mathrm{~m}$, common; C. Salsipuedes, common in Dicksoma-rich forest c. $600 \mathrm{~m}$; Q. Villagra, in many places; $Q$. de la Choza, 3-400 m, not unfrequent.

The island form, which was the type of a species in Herb. BERTERo, but not described by him, seems to be very constant. It differs from the two continental forms in the dense pubescence, the more oblong leaves and the smaller seeds. MÜLlER ARG. distinguished the Chilean form as the type and called the island plant var. hirsuta. I have been inclined to regard the latter as a species. GRÜNING, in »Pflanzenreich»Vol. IV, Pt 147:8, p. 286, retains the forms as varieties; I prefer to regard them as geographical subspecies, as they inhabit widely separated areas and transitions are unknown. Subsp. genuina ranges from Chillan to Fuegia, hirsuta is endemic in Masatierra and paucidentata only known from the Andes of Ecuador. D. *hirsuta is perennial and not, as says GRUNING, annual or perennial; the stamens are mostly six and not three; the petiole often measures $2 \mathrm{~cm}$.

Area of distribution: Endemic in Masatierra: see above. 


\section{Empetraceae.}

\section{Empetrum L.}

73. E. rubrum Vahl.

Masafuera: On the top of L.os Inocentes, c. I $500 \mathrm{~m}$ (no. 379).

An important addition to the magellanic element. Only one large and very old shrub had been discovered when the impenetrable mountain fog closed upon us and forced us to abandon the summit. The specimen was without flower or fruit, but the leaves are quite like those of E. mbrum, such as I have collected it in many places in the south. Islands.

Area of distribution: Cordillera of Valdivia to Fuegia and the Falkland

\section{Rhamnaceae.}

\section{Colletia Comn.}

74. C. spartioides Bert. ex Colla. - JoHow, Estud. IO4.

Masatierra: BERTERo! - Rocky places in the forest region, rare. Pto Frances (acc. to GAY); El Pangal, east wall of the gorge, not far from the waterfall, c. $220 \mathrm{~m}$ (fr. $1 / 117$, no. 226 , also found by JoHOw); NE. precipice of Co Damajuana, 500-550 m; V. Colonial, Q. del Monte Maderugo, $390 \mathrm{~m}$ (fr. ${ }^{24} / 1$ I7, no. 336); Pto Ingles, on the central ridge in a very steep place on the west slope (fr. $19 / 1$ I 7 , no. 320 ).

Seeds ovoid, slightly keeled on their ventral side, 3,5 $\mathrm{mm}$ long, very dark brown to almost black, highly polished. JoHOw describes the leaves as »escasísimas, pequeñas i rudimentárias», but in the young shoots they are numerous and of regular size. The branches soon become leafless.

On BERTERo's label is written: win sylvaticis petrosis montium editiorum». GAY, Bot. II. 35, quotes Colletia from Pto Frances and says that it flowers in March. JoHow lists as collectors only BERTERo and JOHOW, but, as seen above, the species is not quite so rare as has been supposed.

Area of distribution: Endemic in Masatierra.

\section{Flacourtiaceae.}

\section{Azara Ruiz et Pav.}

75. A. fernandeziana Gay. - A. serrata Ruiz et Pav. var. fernandessiana -(Gay) Reiche, Fl. de Chile I. 134; JoHow, Estud. I09. - Fig. I 5 a.

Masatierra: In the montane forest, supposed by JoHow to be limited to a single locality, but found in many places by the writer. Only a single or some few trees were observed in each place. - C. Chifladores, small valley facing the Frances Valley, solitary, c. $500 \mathrm{~m}$; on the ridge separating Q. Laura 10-20400. The Nat. Hist. of Juan Fernandez and Easter Isl. Vol. II. 
fronı Q. Piedra Agujereada, c. $500 \mathrm{~m}$, rare; V. Colonial, below Portezuelo, c. $450 \mathrm{~m}$, one large trec in dense forest (f. ${ }^{3} / 12 \mathrm{I} 6$, no. 8) and $570 \mathrm{~m}$, two small plants; C. Central, c. $400 \mathrm{~m}$; Q. Gutierrez, $350-450 \mathrm{~m}$, rare (fl. $7 / 18 \mathrm{I} 6$, no. 41); Q. Seca, c. $500 \mathrm{~m}$; C. Salsipuedes; mountain ridge west of Co Yunque, $530 \mathrm{~m}$; Q. Villagra, $500-550 \mathrm{~m}$, scattered (unr. fr. Apr. I7, no. 584); Q. de la Choza, several trees, c. $300 \mathrm{~m}$.

In Stud. I 8 I restored GAY's species, saying that it differs quite as much from serrata as this from lanceolata. This statement is not correct, for the

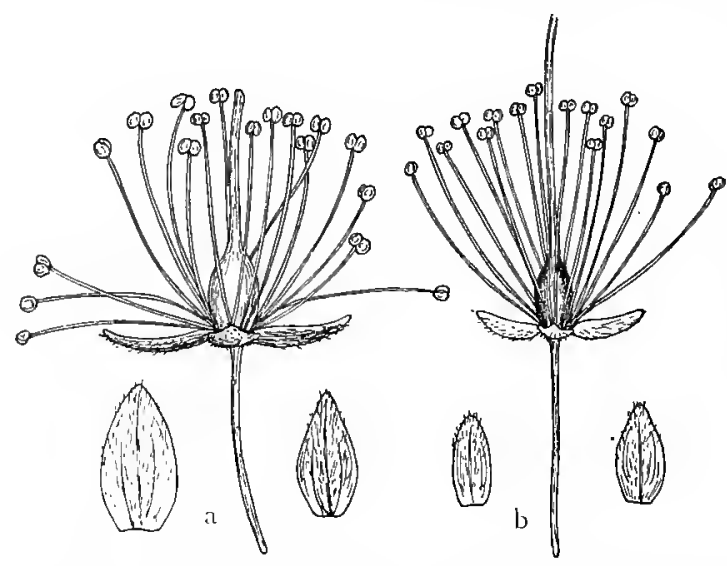

Fig. 15. Flower and sepals of a Azara fernandeziana, b $A$. serrata. $\times 5$. island species is very near serrata. Of the latter I have seen ample material in Santiago and Kew. We learn from the original description (Bot. I. 196), that $A$. fernandeziana has membranous leaves and a fruit twice as long as the calyx, while $A$. scrrata has coriaceous leaves and the fruit three to four times as long as the calyx. The only notable difference in STEUDEL's description (Flora $1856,42 \mathrm{I}$ ) is the glabrous calyx in the former, but the calyx is hairy in both. REICHE tried to distinguish the island form by the broad, thin leaves; JoHow adds that the berries are pure white, while, in $A$. serrata, they are blue and glaucous. I have not seen any quite ripe fruits of $A$. fernandesiana, but all I have are very dark, and I doubt they would have turned white, had they been left to ripen.

The species is upheld with hesitation. Certainly there are differences (see fig. I 5); the leaves are thinner (but not broader, nor are the stipules larger), the pubescence of the stem and peduncles is denser, the sepals $2,5-3 \mathrm{~mm}$ long against $1,5-2$ in serrata, the anthers a trifle larger, the style shorter, $3,5 \mathrm{~mm}$ against $4-5$ in the other.

Area of distribution: Endemic in Masatierra.

\section{Myrtaceae.}

\section{Ugni Turcz.}

76. U. Selkirkii (Hook. et Arn.) Berg. -- Jolıow, Estud. 9I.

Masatierra: Common on the highest ridges above the forest, associated with Pernetty a rigida but much more scarce than this. C. Centinela, $500-800 \mathrm{~m}$; ridges of Co Damajuana, large shrubs (f. ${ }^{29} / 1$ I 7 , no. 352); V. Colonial, C. Central, $450-570 \mathrm{~m}$; Portezuelo de Villagra, the steep slope of Co Pirámide, 575-600 m (buds $22 / 1$ I7, fl. ${ }^{31 / 1}$ I7, no. 329); C. Salsipuedes, 500-700 m.

Area of distribution: Endemic in Masatierra. 


\section{Myrteola Berg.}

\section{*77. M. nummularia (Poir.) Berg.}

Masafuera, in the alpine region: near the Correspondencia Camp, I $30 \mathrm{~m}$ (fr. $5 / 3$ I 7, no. 376); C. del Barril, foot of C. Atravesado, I350 m (past fl.-fr. $1 / 3$ I7, no. 548); east slope of Los Inocentes, c. I $200 \mathrm{~m}$, and below the summit, I350-I $400 \mathrm{nl}$ (fl. -fr. $9 / 3$ I7, no. 377).

Another interesting addition to the subantarctic group. The specimens from Inocentes have almost orbicular leaves, being more stypical», while, in the rest, they are more ovate.

Area of distribution: Chile, Cordillera of Nahuelbuta and Valdivia to Fuegia and the Falkland Islands.

\section{Myrceugenia Berg.}

78. M. fernandeziana (Hook. et Arn.) Berg. - JoHow, Estud. 94.

Masatierra: The leading forest tree, common from near the sea level to the high ridges and ranging from Pto Frances to the westernmost forest patches of Q. Juanango and Co Chumacera. Fl. Dec. I9I6 (nos. 39, 75); unr. fr. March-Apr. 1917 (no. 575).

Area of distribution: Endemic in Masatierra.

79. M. Schulzei Johow, Estud. 96 (as Schulzii, but named in honour of Mr. J. Schulze).

Masafuera: The principal forest tree, forming a belt in the valleys between 200 and $800 \mathrm{~m}$, more or less. Fl. Feb. 1917 (no. 505).

Area of distribution: Endenic in Masafuera.

\section{Gunneraceae.}

\section{Gunnera L.}

8o. G. peltata Phil. - Johow, Estud. 98; Skottsberg, Stud. I2, Fig. 2. Syn. G. insularis Schindl. non Phil. - Fig. 16 a.

Masatierra: Common in the forested parts, preferring humid ravines, where the stem and leaves attain a very great size. Not seen at a lower altitude than $160 \mathrm{~m}$. It reaches the foot of the high ridges, where intermediate forms between this and $G$. bracteata are found. To the west of Villagra, on the south side of the island, $G$. peltata descends into the ravines below the limit of the forest, reaching its farthest west at the foot of Co Tres Puntas. Fl. O-stage Dec. IgI6 (nos. 87, I39); fr. Jan. I9I7 (no. I 39 b).

I have not much to add to my earlier account of this species. This time young plants were found in plenty; they are more or less coarsely villous. The lamina of the first leaves is reniform and not peltate, while the leaves of the 
adult plant nearly always are peltate. Inflorescences collected Dec. I9I6 had lost their petals and stamens. The stigmas were white in these specimens, not crimson as stated for the plants examined before.

Area of distribution: Endemic in Masatierra.

81. G. bracteata Steud. - Johow, Estud. 99; Skotssberg, Stud. io, Fig. 1. Syn. G. insularis Phil. non Schindl. - Fig. 16 b.

Masatierra: In the central parts of the island, much more rare than the former and belonging to the region of dwarf trees and shrubs along the ridges. Seldom found below $500 \mathrm{~m}$. - El Rabanal (JoHow); Pico Central (JoHow); Portezuelo de Villagra, common in the vicinity of the pass, c. $550-600 \mathrm{~m}$ (unr.-fr. ${ }^{3} / 12$ 16, no. I; also observed by JoHow); C. Salsipuedes, scattered in the thickets on the crest, c. $600 \mathrm{~m}$; highest part of Q. Villagra, c. $500 \mathrm{~m}$, with an unusually large stem but otherwise typical. - Forma folits plerumque peltatis: C. Centinela, $700-800 \mathrm{~m}$, common (fr. 11/4 17, no. 610). A remarkable form, found in considerable quantities on the high ridge east of Co Yunque. The leaves generally are peltate; this is, as will be shown below, not uncommon in intermediate forms, explained as hybrids, but no. 610 is a typical bracteata as to all other vegetative characters. Still, it may not be quite pure.

Area of distribution: Endemic in Masatierra.

[G. insularis Phil. (see SiotTsBekg, Stud. 14). Young plants of G. bracteata, collected by the writer, are identical with PInLIPPI's type of insularis in Herb. Santiago, leg. Germain 1854 !

G. pyramidalis Schindl. (sée SkotTsberg, Stud. 14). I have tried in vain to get hold of the type; I am convinced that it is not a separate species. The type consists of a piece of an old spike of BERTERO no. 1463, without leaves or ligules. It differs in the very small bracts, considerably smaller than in the top region even, of the other species. I don't know if the bracts in the type are intact; I have seen old spilies where they have disappeared, leaving a stump standing. In Herb. Kew I saw such a piece of BERTERO I463 (this number embraces all the forms of Gunnera from Masatierra); it belongs to $G$. bracteata.]

G. bracteata Steud. $\times$ peltata Phil. -- Plate 13, 2; text fig. I6 c-i.

Near Portezuelo JoHow found a Gunnera with rugose leaves and entire scales, regarded by him as a bastard between the two species. I have found numerous intermediate forms in several places; as hardly one is like the other, I believe they are hybrids and also that the $\mathrm{F}$ I-generation is fertile so that we get an F 2 and following generations. As the two species differ in many characters and as there are so many possibilities to combine these, the theoretical result will be a long series of forms uniting the two extremes, and this is exactly what we find.

The main differences between peltata and bracteata may be summarized as follows.

G. peltata: Leaves orbicular, reniform of generally peltate, rugose, petiole and lower surface of the blade with scattered tubercles on the larger veins, 
upper surface very rugose. Scales crimson, long and narrow, with thick fleshy midrib, densely and deeply lacerate, very hirsute on back. Scape more or less pilose, bracts linear, oblanceolate-acute. Budding parts not very slimy.

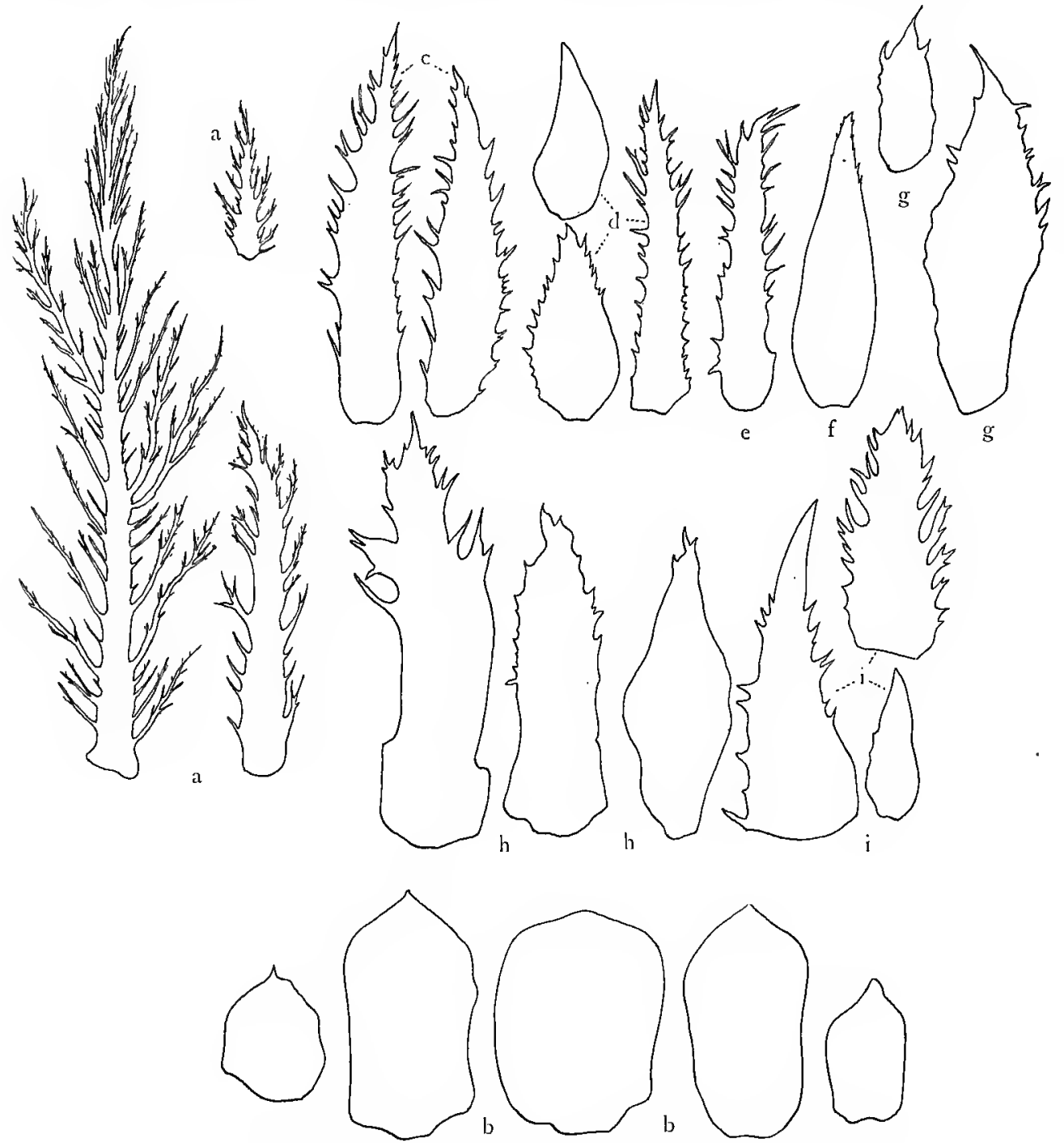

Fig. 16. Scales of Gunnerae: a G. peltata, b G. bracteata, e-i intermediate forms - see text! All $\frac{1}{2}$ nat. size.

G. bracteata: Adult leaves orbicular-reniform, smooth, glabrous and lustrous, petiole smooth. Scales green or brownish green, thin, entire, broad ovate, very blunt but sometimes apiculate. Scape glabrous, bracts spathulate. Budding parts embedded in thick mucilage.

Intermediate forms were observed in Masatierra: Portezuelo de Villagra, near the road, c. $300 \mathrm{~m}$ (no. I230) and one fine specimen c. $500 \mathrm{~m}$ (Plate I 3, 2); close to the pass, c. $575 \mathrm{~m}$ (fr. ${ }^{2} / 4 \mathrm{I} 7$, no. $585,{ }^{20} / 417$, no. 624); C. Salsipuedes, 
$600-650 \mathrm{~m}$, common together with the supposed parents (fr. $8 / 12 \mathrm{I} 6$, no. 80, $13 / 1 \mathrm{I} 7$, no. $80 \mathrm{a}, \mathrm{b})$; Pto Ingles, central ridge, $575 \mathrm{~m}\left(\mathrm{fr} .{ }^{19 / 1} \mathrm{I} 7,110.323\right)$; Q. Villagra, c. $500 \mathrm{~m}$ (fr. $10 / 1$ 17, no. 1218 ).

The following notes on the leaves and scales of these specimens will give an idea of the range of variation.

No. 624. Fig. I6 c. - Adult leaves all peltate, very rugose below, larger tubercles on veins and petiole few, small; blade almost smooth above. Scales linear-triangular, slightly pilose on back, reddish brown; margins short lacerate. Scape glabrous, bracts mostly gone, remaining ones \pm intermediate in shape.

No. 1230. Fig. I6 d. - Leaves peltate, petiole aculeate and pilose, nerves with few tubercles, lower surface rugulose, upper very rough, thus leaves like those of peltata, but the lobes more blunt. Scales entire to short lacerate, ovate to linear-triangulate, reddish brown, pilose on back.

No. 585. Fig. 16 e. - Leaves only slightly peltate, otherwise as in peltata; scales narrow linear to triangular, reddish brown, shortly lacerate, densely pilose on back. Scape pilose, bracts as in peltata. Spile less dense than in this. Budding parts more slimy than in peltata.

No. 323. Fig. I6f. - Leaves not peltate, with acute, serrate lobes, pilose on the nerves below, with few and low tubercles. Scales ovate-triangulate, acute, entire or slightly dentate, brownish green with reddish centre, a little pilose on back. Scape glabrous; no intact bracts left.

No. 80 a. Fig. 16 g. - Leaves slightly or incompletely peltate, slightly rugose below and almost smooth above, petiole strongly aculeate. Scales ovatetriangulate, acute, entire or dentate, greenish brown with reddish centre, glabrous. Scape glabrous, bracts as in bracteata.

No. $80 \mathrm{~b}$. - Like the former, but leaves peltate and nearly smooth on both sides. Scales narrower, rarely dentate, slightly pilose on back. Bracts a little narrower.

No. 80 . Fig. I6 h. - Leaves peltate, smooth, slightly pilose on the nerves; petiole with scattered low emergences. Scales greenish brown with reddish centre, broad linear-triangular, acute, entire or lacerate in the upper half, almost glabrous. Scape nearly glabrous, bracts of peltata type.

No. 1218 . Fig. 16 i. - Leaves not peltate, nearly smooth above, slightly rugose and aculeate below. Scales green, ovate-triangular, acute, entire or lacerate, a little pilose on back. Scape glabrous. No intact bracts left.

\section{G. Masafuerae Slzottsb. - Stud. I4, Fig. 3; Taf. 3-4.}

Masafuera: known before only from $Q$. de las Casas, now found in many places and not at all confined to the canyons, but quite common higher up on the mountain slopes or in the shallow ravines in the alpine region. - Along the road to Las Chozas, open spaces in the forest belt; in the higher treeless tracts betiveen 700 and $1100 \mathrm{~m}$, extensive patches in some places; Q. de las Casas, between stones by the stream and on the rock walls of the canyon (unr.-fr. $23 / 2$ I7, no. 400); Q. de las Vacas, reaching farther down owing to the greater supply of water; $Q$. del Blindado, in the forest, $440 \mathrm{~m}$; $Q$. Angosta, by the waterfall; $Q$. de la Lobería, $280 \mathrm{~m}$, in open forest. Also in the alpine region: 
on the western wall of the island, not uncommon; near Las Torres, $1350 \mathrm{~m}$; top of Ca Correspondencia, c. I400 m.

To my description of I9I4 the following notes should be added. Old trunlks sometimes as much as $1 / 2 \mathrm{~m}$ high and $2 \mathrm{dm}$ across; petiole to $11 / 2 \mathrm{~m}$ long, occasionally as much as $12 \mathrm{~cm}$ wide at base; largest lamina measured $2,87 \mathrm{~m}$ across. Scales densly pilose on back, as in G. peltata. Largest scapes measured $I, 6_{7}$ and $I, 75 \mathrm{~m}$, respectively, very heavy, drooping, as much as $26 \mathrm{~cm}$ across at base.

This species has larger leaves than the other Juan Fernandez species. Besides by other characters, it is distinguished by the branches of the spike becoming conspicuously incrassate in the fruiting state. The fruit is bright orange red turning crimson when ripe.

In No. 400 transitions were found between normal leaves and the so-called "ligules», showing that the latter are not ligular structures, but reduced leaves, homologous with the large green leaves as well as with the reduced bracts. I shall return to these organs in another paper.

The young petioles of $G$. Masafuerae have a more agreeable, less acid taste than those of $G$. peltata; they are quite refreshing, a fact well known to the islanders, who distinguished $G$. Masafuerae as a special sort of »nalca» (native name for the petioles) long before it was described by the writer.

Area of distribution: Endemic in Masafuera.

Halorrhagidaceae.

\section{Halorrhagis Forst.}

A species of Halorihagis was first collected in Masatierra by Mrs. GRAHAM in 1823 and later by Scouler, Bertero, Cuming, Germain, Phil.ippi, Reed, MOSELEY and JoHOW, also by me in 1908. I have seen specimens brought by all these collectors. ScHindler, Pflanzenreich, also quotes J. D. Hooker, who never visited Juan Fernandez. All the specimens were referred to one species and identified with Cercodia erecta Murr. Comment. Goetting. II (1780) 3 tab. I $=H$. alata Jacq, $=H$. erecta (Murr.) Schindler, l. c. IV. 225 (1905) 49, fig. 14. The plant from Masatierra goes under one of these names in all publications and herbaria, also in the monograph of SCHINDLER. In Igo8, the same name was used by me, on the authority of SCHINDLER. . At that time I had no reason to doubt his statements, with one exception, viz. that he quotes $H$. erecta as a native of Chile (GERMAIN); it does not occur on the continent, and Germain's specimens came from Juan Fernandez.

After I had discovered a number of forms in Masafuera, I began to study $H$. crecta from New Zealand and found that the plant from Masatierra was a distinct species. It is evident that SCHINDLER based his description on specimens from both New Zealand and Juan Fernandez (Masatierra).

Before my visit in 1908 Halorrhagis had been brought from Masafuera only by GERMAIN. No distinction was made between this and the form in Masatierra. Both are quite smooth, but otherwise very different from each 
other. I have seen GERMAIN's plant and I have collected the same species in several places in 19I7. The form I found in 1908 was, however, not this, but a very scabrous one, more like the true $H$. erecta; it was mentioned in my account as var. scabra. I have found it in many places in 1917 , in flower and fruit. It stands very near erecta, but must be kept separate.

Thus, $H$. erecta does not occur in Juan Fernandez, but is replaced by three different species. On the other hand, it seems that $H$. crecta of New
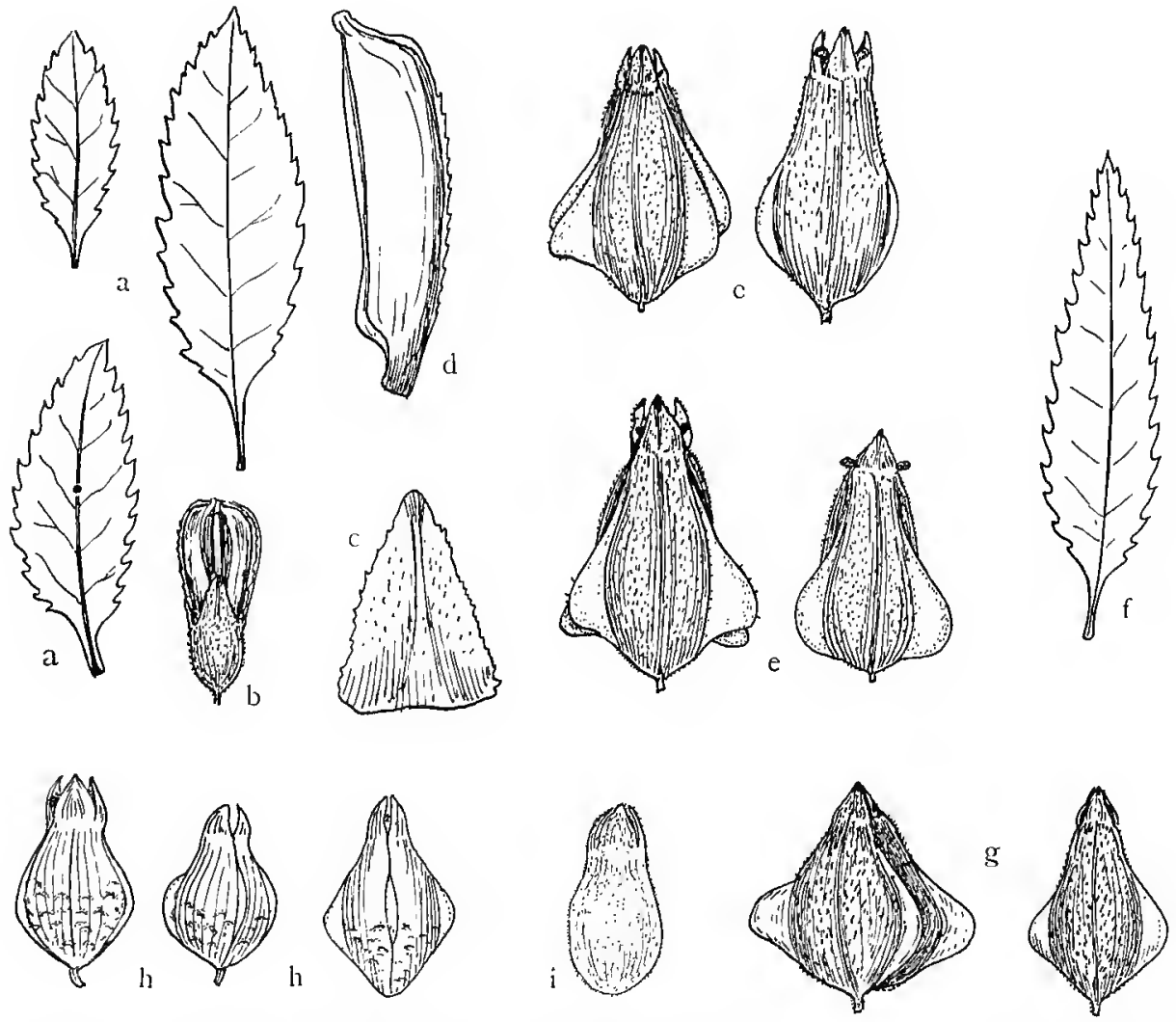

Fig. I7. a-e Halorrhagis erecta, cult. a leaves, nat. size, b bud, $\times 6,6, \mathbf{c}$ sepal and a petal, $\times 20$, e fruits, $\times 6,6 . \quad \mathbf{f}-\mathrm{g} H$. erecta leg. Cheeseman: f leaf, nat. size; $g$ fruits, $\times 6,6$. h fruits of $H$. Colensoi and $\mathrm{i}$ of $H$. cartilaginea, $\times 6,6$.

Zealand comprises two distinct plants. MURRAY described a scabrid plant with alate fruits (see fig. I7 a--g). In Herb. Kew I saw specimens of this lind collected by Forster, Cunningham, Buchanan, J. D. Hooker, Cheeseman a. o. FORSTER's specimens are less scabrous than the rest. But under the same name was a smooth form collected by CoLENSO, with small, barely alate fruits, recalling my $H$. masatierrana in habitus, but differing in the shape and size of the fruit (see fig. I7 h). I have called this $H$. Colensoi.

$H$. cartilaginea Cheesem., later reduced to a variety of $H$. erecta (Man. N. Z. Flora I48) was justly reestablished by SCHINDLER. It seenis to be 
a very distinct species (fig. I 7 i). To the same subsection Cercodia (Murr.) Schindl. also belong $H$. laevis, exalata and pedicellata, all natives of Eastern Australia.

Key to Subsect. Cercodia.

I. Sepals trideritate

H. pedicellata Sclindl.

II. Sepals entire.

A. Whole plant more or less scabrid.

I. Densely scabro-velutinous. Leaves thick, broadly ovate.

2. Coarsely scabrid. Leaves thin.

$H$. cartilaginea Cheesem.

a. Stem with large, scattered hooks. Teeth of leaves pungent.

H. exalata F. Müll.

b. Stem with minute prickles, teeth of leaves not pungent.

a. Leaves barely scabrous. Stigma papillae few celled. Fruit more than $3 \mathrm{~mm}$ long. -............ H. evecta (Murr.) Schindl.

$\beta$. Leaves very scabrous. Papillae multicellular. Fruit hardly $3 \mathrm{~mm}$ long. H. asperrima Skottsb.

13. Whole plant perfectly smooth.

1. Leaves large, narrow lanceolate.

H. laevis Schindl.

2. Leaves ovate or broad lanceolate.

a. Fruit large, generally over $4 \mathrm{~mm}$.

$\alpha$. Narrow ovoid, distincly costate. H. masatierrana Skottsb.

$\beta$. Broad ovoid, not costate. ........... H. masafuerana Skottsb.

b. Fruit small, c. $3 \mathrm{~mm}$ long. .......................... Colensoi Skottsb.

\%3. H. asperrinia nov. spec. - Syn. H. erecta var. scabra, SkotTsBERG, Stud. - Fig. I 8 .

Suffrutex semimetralis, glaber sed scaberrimus, fere a basi opposite ramosus. Rami tetragoni longitudinaliter ac conspicue 4 -lineati, lineis elevatis valde scabris. Folia opposita, superiora saepe alternantia, internodiis sat longis separata, tenuia, laete-obscure viridia subtus paulo pallidiora, ubique asperrima, ovata vel ovato-lanceolata, basi cuneato-rotundata, longe (IO- $18 \mathrm{~mm}$ vel interdum ultra) petiolata, lamina argute serrata dentibus distincte apiculatis utrinque I 2-I $4,30-50 \mathrm{~mm}$ longa et $10-22 \mathrm{~mm}$ lata, superiora sensin minora, pro magnitudine longe petiolata, anguste lanceolata - ovato-rhomboidea, parcius dentata - subintegra. Inflorescentia spicata foliosa, e dichasiis bracteolatis 3-7floris composita. Flores brevissime pedicellati $(1 / 2 \mathrm{~mm})$, omnino scabri. Ovarium tetragono-ovoideum, interdun mox alatum, $\mathrm{I}, 2_{2}-\mathrm{I}, 5 \mathrm{~mm}$ longum et $\mathrm{I} \mathrm{mm}$ latum. Sepala 4 acute triangulata, minute denticulata, $0,8-0_{9} \mathrm{~mm}$ longa. Petala 4 navicularia, carinata et in carina scabra, breviter unguiculata, $2-2,5 \mathrm{~mm}$ longa, viridia-alborosea. Stamina 8 filamentis tenuissimis c: $1,5 \mathrm{~mm}$ longis, antheris flavis dorso \pm rubescentibus, I-I,5 $\mathrm{mm}$ longis. Styli 4 , ad $0,8 \mathrm{~mm}$ longi, stignata alba vel rosea papillis longis multicellularibus. Fructus scaber, viridis-obscure violaceus tetragono ovoideus pyriformis exalatus vel 4-alatus, cum sepalis persistentibus $2,7-3 \mathrm{~mm}$ longus et $2 \mathrm{~mm}$ latus, inter margines alarum autem ad $4 \mathrm{~mm}$ metiens. 
Masafuera: Skól'sberg I908, ster. - Q. de las Casas, quite common (f..fr. ${ }^{11 / 8}$ 17, no, 457 - f. fructibus alatis); $Q$. de las Vacas (fl.-fr. 10/2 17, no. 442 - f. non alata); Q. del Blindado, in the forest c. $440 \mathrm{~m}$; Q. del Varadero; on the precipice above Buque Varado, c. $1200 \mathrm{~m}$.

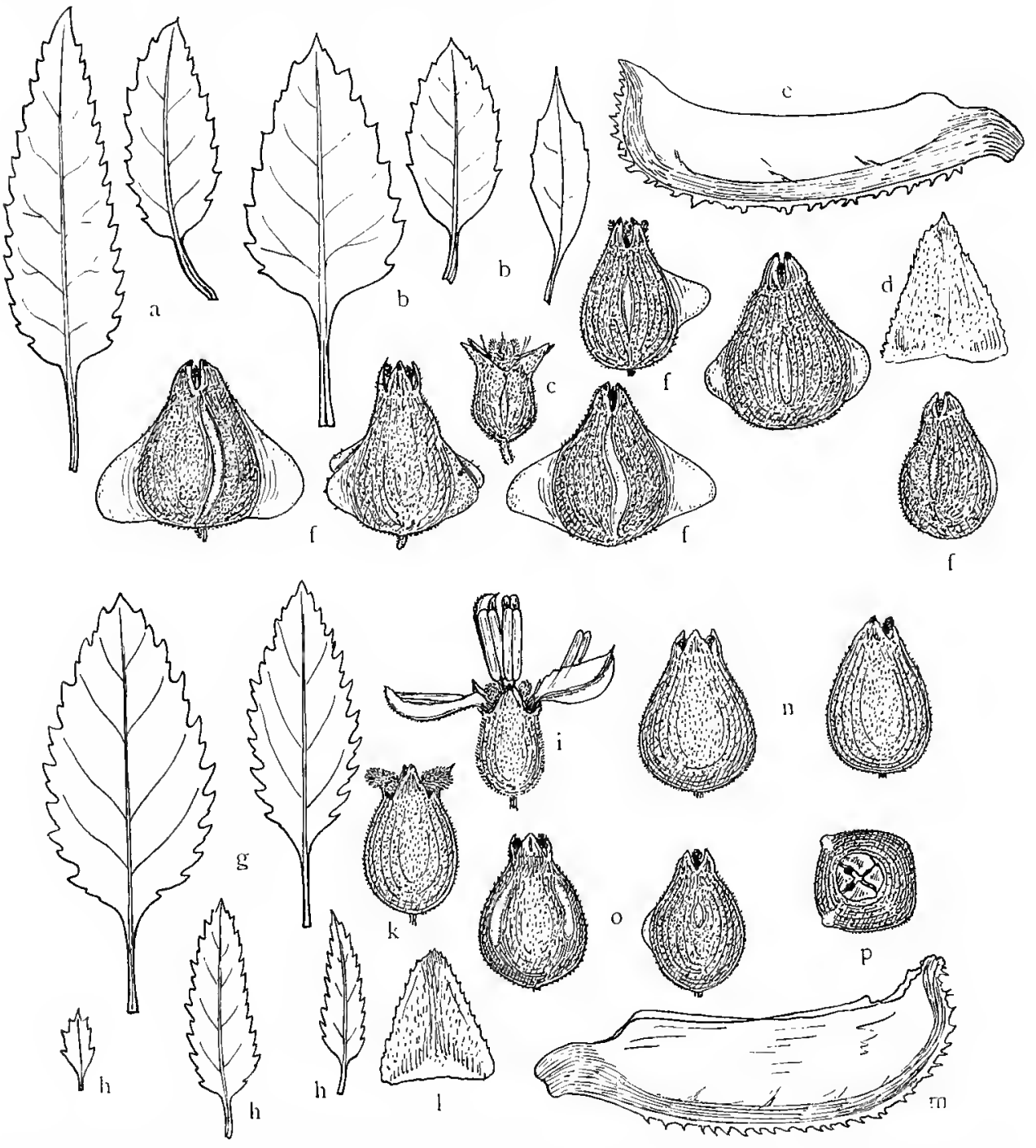

Fig. 18. Halorrhagis asperrima; a-f from no. 457: a two lower and b three upper leaves, nat. size; c flower (petals and anthers removed), $\times 6,6$; d sepal and e petal, $\times 20$; f fruits, $\times 6,6$. $\mathbf{g}-\mathbf{p}$ from no. $442: \mathbf{g}$ two lower, $\mathbf{h}$ three upper leaves, wat. size; $\mathbf{i}$ flower on male and $\mathbf{k}$ on female stage, $\times 6,6 ; 1$ sepal and $m$ petal, $\times 20 ; \mathbf{n}$ typical fruits, o with trace of wings, $\mathbf{p}$ one of these seen from the top, all $\times 6,6$.

No. 457 and 442 are so unlike each other that I have been inclined to bring them to different species. No. 457 is wholly green, the leaves are broader, especially in the floral region, the branches thinner, the fruit mostly alate with low, broad wings, see fig. 18 a-f. No. 442 is more or less tinged with antho- 
cyanin - though never so bright red as $H$. erecta --, the leaves are narrower, the fruit only slightly tetragonous and mostly without a trace of wings, see fig. $18 \mathrm{~g}-\mathrm{p}$. Fruits from both numbers were sown in the Gothenburg Garden and yielded numerous plants; at present I have 13 specimens of no. 457 and 32 of no. 442 in cultivation. The latter are exactly like the mother plant, but the former are unlike no. 457 and habitually very like no. 442 . Still, small wings develop in many fruits as in the mother plant, but not so regularly. I suppose the difference in vegetative characters is due to external conditions, but it is less probable that these should influence the development of wings.

$H$. asperrima is very near $H$. erecta, but this is less scabrous and the leaves are nearly smooth, especially the margin, which, in $H$. asperrima, is thickly beset with microscopic aculei. The stigma-papillae are mostly 2-celled and the fruit 3,5-4 $\mathrm{mm}$ long in erecta.

Area of distribution: Endemic in Masafuera.

84. H. masatierrana nov. spec. - H. alata (erecta), JoHow, Estud. 97, SkotTsberg, Stud. 10, non Murr. nec Jacq.; SCHINDler in Pfanzenreich p. p. - Fig. 19.
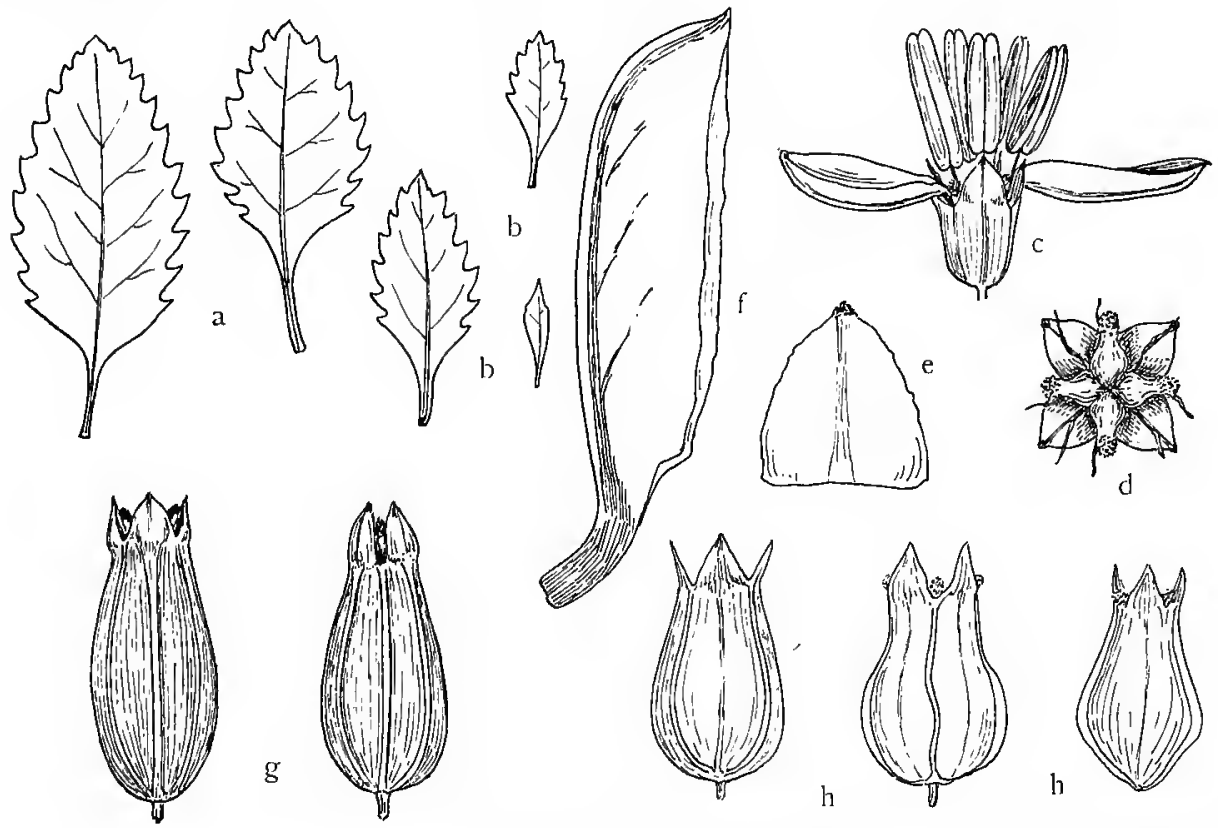

Fig. 19. Halorrhagis masatierrana: a two lower, b three upper leaves, nat. size; c flower on mille and $d$ on female stage, $\times 6,6$; e sepal and $f$ petal, $\times 20 ; \mathrm{g}$ fruits of no. 304 , $h$ of JoHow no. 6 , all $\times 6,6$.

Suffrutex $2-5 \mathrm{dm}$ altus, glaber, laevissimus, fere a basi opposite ramosus. Rami cylindraceo-tetragoni, longitudinaliter 4 -lineati, cortice \pm rufescente. Folia omnia opposita vel superiora florigera alternantia, discoloria, supra laete viridia, subtus glaucescentia, inferiorum lamina ovata, acuta, basi late cuneata, petiolo $3-8 \mathrm{~mm}$ longo suffulta, plerumque $15-30 \mathrm{~mm}$ longa et 9-14 $\mathrm{mm}$ lata, 
regulariter serrata dentibus utrinque $6-9$, superiora multo minora, paucidentatasubintegra, basi longe cuneata, suprema bracteiformia. Inflorescentia densa vel laxa, foliosa, e dichasiis bracteolatis plerumque 3 -floris composita. Flores brevissime $(1 \mathrm{~mm})$ pedicellati, omnino laeves. Ovarium subtetragonum et sat distincte 8-lineatum, $0,9-1 \mathrm{~mm}$ longum et fere latum, cum pedicello \pm rufescens. Sepala 4 late ovato-triangularia, suberecta, $0,9 \mathrm{~mm}$ longa. Petala 4 navicularia alborosea carinata, $3-3,5 \mathrm{~mm}$ longa, manifeste unguiculata. Stamina 8 filamentis c. $1 \mathrm{~mm}$ longis, antheris flavo-roseis $2-2,3 \mathrm{~mm}$. Styli $4,0,8 \mathrm{~mm}$ longi, stigmata rosea papillis pauci- $(\mathrm{I}-3)$ cellularibus. Fructus anguste tetragonoovoideus, in specim. uum. 304 cum sepalis $4-4,5$ mm longus et $\mathrm{I}, 7-\mathrm{I}, 9 \mathrm{~mm}$ latus, non alatus sed lineis paulo elevatis 8 notatus, fusco-viridis.

Masatierra: Not rare on the dry, rocky ridges, also on open, stony ground in the forest belt. Rabanal (JOHOw); El Pangal, on the western slope; C. Centinela (JoHow); V. Colonial, C. Central (also JoHow), $570 \mathrm{~m}$ (fl.-fr. ${ }^{18} / \mathrm{s}$ I7, no. 304), Q. del Monte Maderugo, road-side in the macal, $240 \mathrm{~m}$, and rocky wall, $390 \mathrm{~m}$; C. Salsipuedes, frequent, $350-650 \mathrm{~m}$ (fl. ${ }^{20} / 12$ I6, no. I72); Portezuelo de Villagra, not rare on both sides (f. $3 / 12$ I6, no. 34 -- also observed by JoHow); ridge between Vaquería and $Q$. Juanango, $300 \mathrm{~m}$; $Q$. Juanango, outer part. South side of the island, Q. Villagra, rare in the forest c. $500 \mathrm{~m}$; east side of $B$. Chupones, barren slopes.

This differs widely from the typical scabrous $H$. erecta, but it is more like what I have called $H$. Colensoi, especially the more stunted form of $H$. masatierrana, growing on the sunny ridges (no. 34, 172). Of this I got no fruits. JoHow collected fruiting specimens of exactly the same habitus (no. 6). The fruits of these, only $3,5-4 \mathrm{~mm}$ long (but hardly quite ripe) come very near $H$. Colensoi, where, however, they are transversely rugose. Both have traces of wings (see fig. $19 \mathrm{~h}$ and $17 \mathrm{~h}$ ). Still, I believe there is only one species in Masatierra and that $H$. Colensoi is different.

Area of distribution: Endemic in Masatierra.

85. H. masafuerana nov. spec. - Syn. H. alata, JoHow, Estud. 98 quoad plantam e Masafuera. - Fig. 20.

Suffrutex semimetralis patente opposite ramosus glaber laevissimus. Rami cylindracei-obscure tetragoni 4-lineati. Folia subcarnosula laete viridia, inferiora petiolo 8-Io $\mathrm{mm}$ longo suffulta, lamina ovato-lanceolata, basi late cuneata, margine incrassata, grosse serrata dentibus utrinque 9-1 I, c. $45 \mathrm{~mm}$ longa et $20 \mathrm{~mm}$ lata, superiora sensim minora et brevius petiolata, suprema subrhomboidea subintegra. Inflorescentia laxa foliosa, e dichasiis bracteolatis I-3 (rarius ad 5)floris composita. Flores brevissime $(1 / 2-1 \mathrm{~mm})$ pedicellati, omnino laeves. Ovarium ovoideum $I, 5 \mathrm{~mm}$ longum et $I_{, 2}$ latum. Sepala 4 triangulata margine integro, $1-\mathrm{I}, 2 \mathrm{~mm}$ longa. Petala 4 viridia fusconotata, navicularia, carinata, manifeste unguiculata, $2,5-3 \mathrm{~mm}$ longa. Stamina 8 filamentis ad I,5 mm longis, antheris ad $1,6 \mathrm{~mm}$. Styli sepalis aequilongi, stignata alba, papillis longis sed paucicellularibus. Fructus pyriformis quam in ceteris major, cum sepalis 4,a-4,6 mm longus, basi $3-3,2 \mathrm{~mm}$ latus, fere semper alis omnino destitutus, maturus \pm violascens, in sicco obscure 4 -sulcatus. Adsunt specimina fructibus tuberculatis nec non alia fructibus irregulariter alulatis. 
Masafuera: Germain oct. I854 (Herb. Santiago!); Q. de las Vacas, on the walls in the outer section (fr. ${ }^{10} / 2 \mathrm{I} 7$, no. $44 \mathrm{I}-\mathrm{f}$. tuberculata); stony beach near Varadero (fr. ${ }^{22} / 2 \mathrm{I} 7$, no. 1216 ); Q. de la Lobería, near the shore (fr. ${ }^{17} / 217$, no. $485-f$. alulata).

H. masafuerana differs from all others in the size and shape of the fruit and in the smooth, shiny stems, leaves etc. I have sown seeds of all the different numbers; of no. 1216 I have numerous, of $44 \mathrm{I}$ a few plants in cultivation. The difference between them is slight, and the tubercles on the fruit of

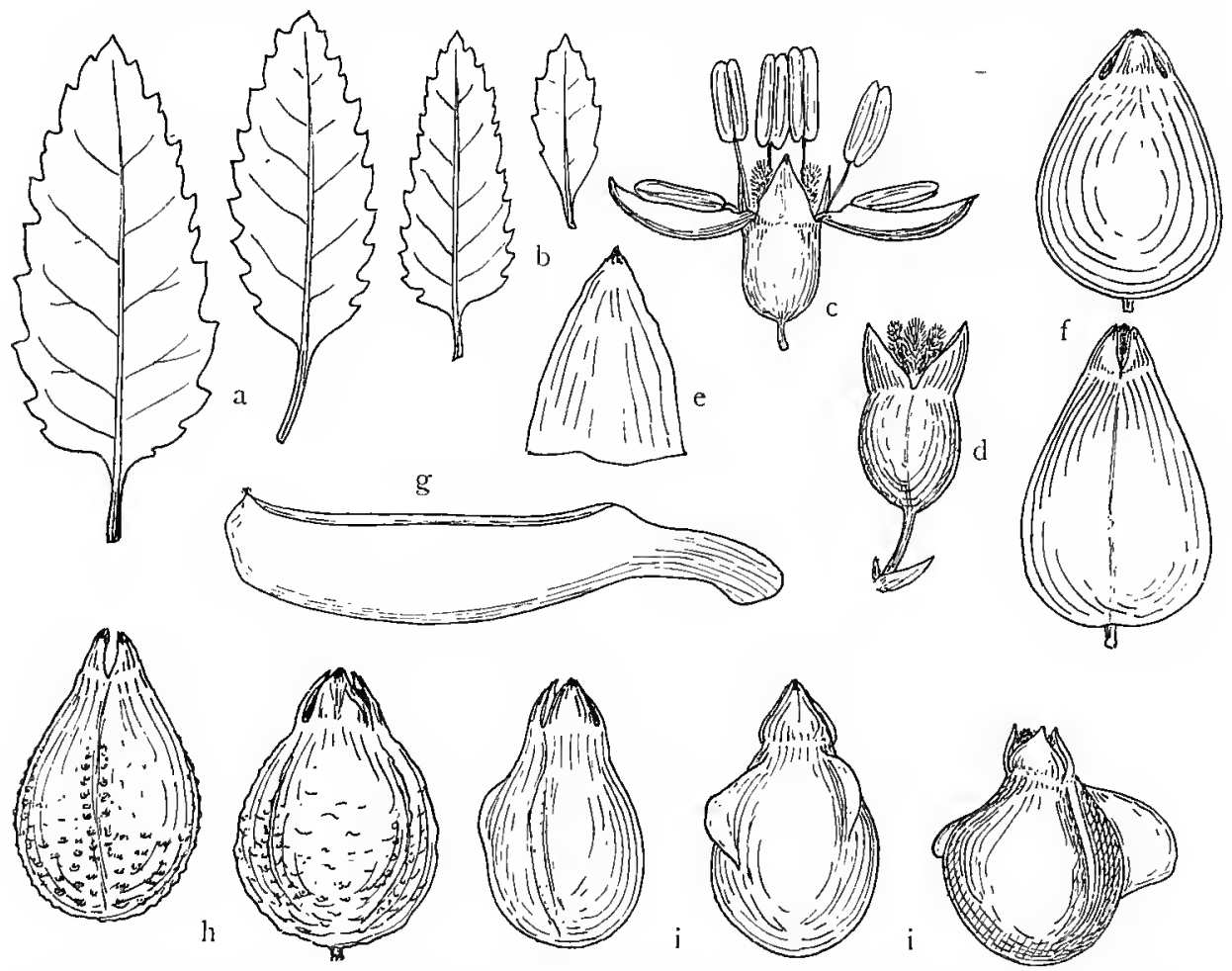

Fig. 20. Halorhagis masafuerana; a-f from no. I216: a lower, b upper leaves, nat. size; c flower on male and $d$ on fenale stage, $\times 6,6$; e sejal, $\times 20 ; f$ fruits $\times 6,6$. $g-h$ from no. $44 \mathrm{I}: \mathrm{g}$ petal, $\times 20 ; \mathrm{h}$ fruits, $\times 6,6 ; \mathrm{i}$ fruits of no. $485, \times 6,6$.

the latter become pronounced only with desiccation, but are quite wanting even in the dry fruits of no. I 216 . More material is needed to decide whether no. $44 \mathrm{I}$ represents a distinct variety. Of no. 485 , the seeds did not germinate. Fruits of all the forms are figured.

Area of distribution: Endemic in Masafuera.

Umbelliferae.

Eryngium L.

86. E. bupleuroides Hook et Arn. - Johow, Estud. ioo; Skottsherg, Stud. I6, Taf. 5, Fig. 4. - Fig. 2 I a-g. 
Masatierra: Not uncommon near the limit of the forest, along the higher ridges etc., rarely seen below $400 \mathrm{~m}$. - C. Centinela, rather common on the ridge (also observed by JOHOW); El Pangal, west branch, on the slopes from $400 \mathrm{~m}$; in the gap between Co Damajuana and Co Yunque, c. $580 \mathrm{~m}$; V. Colonial, C. Central, 400-570 m, scattered; Q. del Monte Maderugo, steep slopes 390$500 \mathrm{~m} \mathrm{(fl.}{ }^{24} / 1$ I7, no. 335); Portezuelo de Villagra, on both sides (fl.-fr. Dec. I916, no. 4, also observed by JoHow); Pto Ingles, central ridge, c. $470 \mathrm{~m}$; the ridge between Vaquería and Q. Juanango, c. $300 \mathrm{~m}$; forest on a mountain spur west of Co Yumque, $550 \mathrm{~m}$; Q. de la Choza, foot of the steep ridge, $400-450 \mathrm{~m}$; south wall of Co Chumacera.

Area of distribution: Endemic in Masatierra.

*87. E. inaccessum nov. spec. - Plate I2. Text fig. 2 I h-p.

Arbuscula glaberrima saltem ad $1 / 2 \mathrm{~m}$ alta, parce pseudodichotome ramosa. Radix primaria profunde infossa parce ramosa. Truncus primarius ad $25 \mathrm{~mm}$ diam., cortice fusco leviter longitudinaliter striato et passim transverse rimoso; rami ultimi cicatricibus foliorum densissine annulati. Folia ad apices ramorum densissime rosulata, semiamplexicaulia, sessilia, valde firma, crassiuscula, obscure viridia et subnitida nervis perplurimis parallelis (circ. $5-7$ crassioribus) percursa, late lineari-lanceolata, acutissima, apice pungentia, $10-15 \mathrm{~cm}$ longa et $1,8-2,7 \mathrm{~cm}$ lata, basi $1,6-2 \mathrm{~cm}$; maxima visa $17,5-23 \mathrm{~cm}$ longa et $2,8-3,8 \mathrm{~cm}$ lata, basi $1,8-2,6 \mathrm{~cm}$; margine angustissime scariosa, infra apicem dentibus acutissimis pungentibus utroque latere $1-4$ (plerumque $2-3$ ) munita, rarissime integerrima. Inflorescentia terminalis monocephala, scapo complanato $6-1 \mathrm{I} \mathrm{cm}$ longo circ. $5 \times 7 \mathrm{~mm}$ diam., cavo, viridi-violaceo. Involucrum ad 23-phyllum phyllis crassis durisque, acutis, pungentibus, basi incrassatis, supra obscure violaceis, subtus viridibus, anguste triangulatis, nargine paulo incrassatis, $20-25 \mathrm{nmm}$ longis et 4-5 $\mathrm{mm}$ latis. Capitulum magnum atroviolaceum depresso-hemisphaericun, $2 \mathrm{I}-27 \mathrm{~mm}$ altum et $27-37 \mathrm{~mm}$ latum; receptaculum vaginis bractearum profunde alveolatum, intus cavum, caverna ad $17 \mathrm{~mm}$ lata et $13 \mathrm{~mm}$ alta, pariete $2 \mathrm{~mm}$ solum crasso. Bracteae anguste rectangulato-subspathulatae, firmae, subcarnosae, basi incrassatae albae, amplexiflorae, apice truncatae et obscure violaceae, margine angustissime albonotatae, ad $7-8 \mathrm{~mm}$ longae et basi $2-3 \mathrm{~mm}$ latae. Flores numerosissimi, jam deflorati solum visi, staminibus exceptis $7 \mathrm{~mm}$ longi. Sepala rectangulata, cochleata, apice truncata et \pm emarginata, sat crassa, alboviridia apice obscure violacea, $3-3,5 \mathrm{~mm}$ longa et $1,5-2 \mathrm{~mm}$ lata. Petala ex albo violascentia, duplicato-inflexa, apice subdentata, $2-2, \mathrm{~mm}$ longa et $0,7 \mathrm{~mm}$ lata, mox decidua. Stamina violacea flamentis $5 \mathrm{~mm}$ longis apice incurvis, antheris ovatis $\mathrm{I}, 5 \mathrm{~mm}$ longis. Stylopodium crateriforme viride; styli 3-4 $\mathrm{mm}$ longi, atroviolacei. Mericarpium fuscum subnitidum 4-5 mm longum et $2,5 \mathrm{~mm}$ latum, ambitu truncato-ovale, late et obtuse carinatum, dorso laeve vel inconspicue tuberculatum, sub apice appendicibus calycinis sat magnis ornatum, margine anguste alatum nec non dentatum.

Masatierra: Portezuelo de Villagra, on the precipitous walls facing SW. and SE., c. $620 \mathrm{~m}$, about a dozen specimens seen (past fl. ${ }^{25} / 12$ i6, no. 196).

$A$ very distinct and conspicuous species of the well known insular type of rosulate dwarf-trees; in spite of growing close to the most frequented spot 

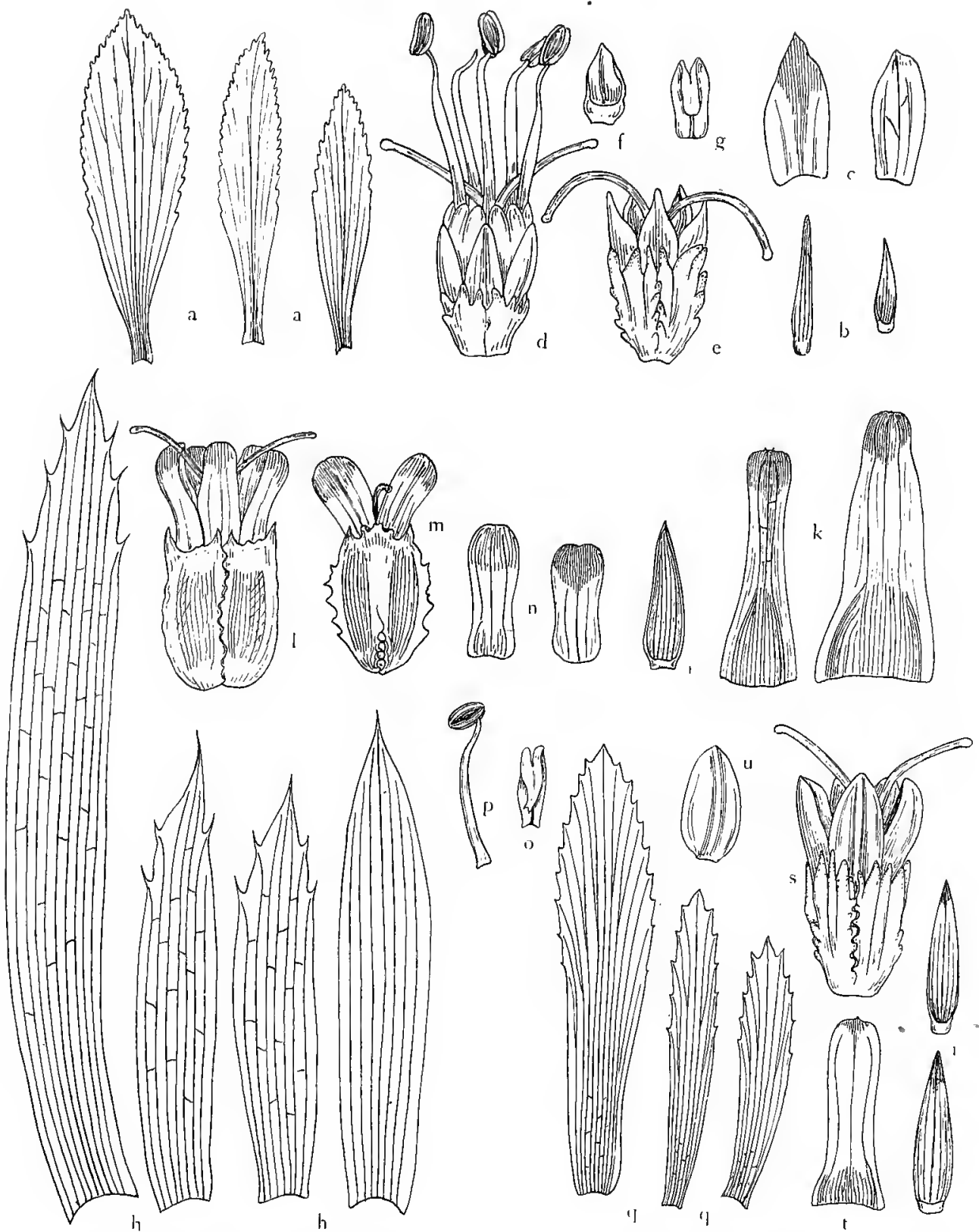

Fig. 2I. a-g Eryngium bupleuroides: a leaves, $\frac{1}{2}$ nat. si\%e; b involucial leaves, outside and inside, nat. size; c bracts, ontside and inside; $\mathbf{d}$ flower; e id. in fruit; $\mathbf{f}$ sepal (inside); $\mathbf{g}$ petal; $\mathrm{c}-\mathrm{g} \times \mathrm{s} . \mathrm{h}-\mathrm{p}$. E. inaciessum: $\mathrm{h}$ leaves, $\frac{1}{2}$ nat. size; $\mathrm{i}$ involucral leaf (inside), nat. size; $\mathrm{k}$ bracts, inside and outside; 1 fruit, m mericarp from the back, $n$ sepals, o petal, $p$ stamen; $k-p \times s$. $\mathrm{q}-\mathrm{u}$ E. fernandesionmm: $\mathrm{q}$ leaves, $\frac{1}{2}$ nat. size; $\mathrm{r}$ involucral leaves, inside and outside, nat size; s flower, t bract, u sepal; s-u $\times 5$.

in the island it seems to have escaped the attention of all earlier visitors. The place where it was found is a perfectly perpendicular and thoroughly inaccessible 
rock wall, and it cost us considerable trouble to obtain sufficient material. The photograph on Plate $\mathbf{I} 2$ is of a complete specimen that liad been lowered down from the cliff.

Area of distribution: Endemic in Masatierra.

88. E. fernandezianum Sliottsb. Stud. 17, Fig. 5. - Fig. $21 \mathrm{q}-\mathrm{u}$.

Masatierra: Portezuelo de Villagra, c. $600 \mathrm{~m}$, two specimens at the foot of the crest west of the pass (past fl. $24 / 12$ 16, no. 188).

Described from a fragment without flowers or fruit, collected by me in 1908 , as far as I can understand taken from one of the two bushes seen in 1917. They bore flower heads, but petals and stamens were gone. No ripe fruits were encountered. A complete description is given below.

Arbuscula glaberrima $0,75 \mathrm{~m}$ saltem alta, erecta, pseudodichotome ramosa, ramis 5-10 mm crassis, junioribus creberrime annulatis. Folia ad apices ramorum confertissime rosulata, firma et crassiuscula, basi tenuiora subamplexicaulia, nervis perplurimis parallelis percursa, nervo centrali magis conspicuo et in pagina inferiore leviter incrassato, linearia, subspathulata, acuta, margine in parte dimidia vel tertia superiore serratodentata dentibus mitibus utroque latere 5-9 (plerumque 6 vel 7), $6-12,3 \mathrm{~cm}$ longa et $\mathrm{II}-25 \mathrm{~mm}$ lata, basi 9- $12 \mathrm{~mm}$. Inflorescentia terminalis monocephala, scapo $5-6 \mathrm{~cm}$ longo et $3 \mathrm{mn}$ crasso superne cavo. Involucrum circ. I 8 phyllum phyllis longissime triangulatis acutis basi incrassatis, margine inferne scariosis, supra colore fuscoviridi in violaceum spectante, subtus viridibus, ad $20 \mathrm{~mm}$ longis et $5 \mathrm{~mm}$ latis. Capitulum circ. $17 \mathrm{~mm}$ altum et 20 latum, viridi-violascens. Receptaculum cavum caverna 6-9 $\mathrm{mm}$ alta et $8-12 \mathrm{~mm}$ diam. Bracteae lineari-subspathulatae, apice truncato-rotundatae, basi incrassatae, $5 \mathrm{~mm}$ longae et 1,5-2 latae, hyalino-albidae, apice violaceae. Flores confertissimi omnes jam deflorati, $6 \mathrm{~mm}$ longi et $3 \mathrm{~mm}$ diam. Sepala ovata, rotundato-acutata, margine scariosa, viridia, apice violascentia, $2,5-3 \mathrm{~mm}$ longa et $\mathrm{I,5}-\mathrm{I}, 7 \mathrm{~mm}$ lata. Petala... Stanina... Stylopodium crateriforme obscure viride. Styli $4,5-5 \mathrm{~mm}$ longi virides. Mericarpium immaturum $3,5 \mathrm{~mm}$ longum, viride, sectione triangulare, apice circumcirca appendiculatum, dorso et margine appendiculis humilioribus ornatum.

I am strongly inclined to regard this as a bastard between E. bupleuroides and $E$. inaccessum. This idea did not occur to me when describing the species, as one of the supposed parents was unknown at that time. In most characters it is intermediate between the two. The cortex is more as in E. inaccessum, but the internodes sometimes slightly longer. The leaves are exactly intermediate in shape and size (see fig. $2 \mathrm{I}$ ), and so are the marginal teeth in shape and number; they are not pungent. The midrib is more conspicuous than in E. inaccessum, where all the principal veins are of the same strength, but less prominent than in E. bupleuroides. The scape and receptacle are hollow as in the former. The involucral leaves are intermediate in shape, size and number, being green in $E$. bupleuroides. The head stands between the two in shape and size and so do the sepals. The fruit is more like that in E. bupleuroides. No ripe seeds were found. In anatomical structure the fruit takes an intermediate position. Both the supposed parents grow close to the place where E. fermandezianum was found, and its great scarcity speaks rather in favour of 
a hybrid origin. It is certainly one of the very rarest plants in the island. Still, no proofs that it is a bastard can be given at present.

The following figures illustrate the intermediate position:

\begin{tabular}{|c|c|c|c|c|c|c|}
\hline & $\begin{array}{l}\text { Number of } \\
\text { teeth in } \\
\text { leaves }\end{array}$ & $\begin{array}{c}\text { Number } \\
\text { of in- } \\
\text { volucral } \\
\text { leaves }\end{array}$ & $\begin{array}{c}\text { Size of } \\
\text { involucral } \\
\text { leaves, } \\
\text { mn }\end{array}$ & $\begin{array}{c}\text { Size of bracts, } \\
\mathrm{mm}\end{array}$ & $\begin{array}{c}\text { Size of sepals, } \\
\text { mm }\end{array}$ & $\begin{array}{c}\text { Length } \\
\text { of style, } \\
\text { nmm }\end{array}$ \\
\hline E. bupleuroides & $8-18(10-I 1)$ & $10-12$ & $10-20 \times 3$ & $3,5-4 \times J, 5-2$ & $2-2,5 \times 1-1,2$ & 6 \\
\hline E. fernandezianum & $5-9(6-7)$ & $16-18$ & $20 \times 4-5$ & $5 \times 1,5-2$ & $2,5-3 \times 1,5-I, 7$ & $4,5-5$ \\
\hline$E$. inaccessum & $I-4(2-3)$ & $18-23$ & $|20-25 \times 4-5|$ & $7-8 \times 2-3$ & $3-3,5 \times 1,5-2$ & \\
\hline
\end{tabular}

Area of distribution: Endemic in Masatierra.

89. E. sarcophyllum Hook et Arn. - JoHow, Estud. IO1; SkOTT'SBERG, Stud. I6, Fig. 4, Taf. 5 Fig. 5.

Masafuera: coast cliffs, very local: Cuming! JoHow! - Between Varadero and Tierras Blancas (fr. ${ }^{17} / 2$ I7, no. 402); Rodado del Sándalo.

Area of distribution: Endemic in Masafuera.

\section{Apium L.}

9o. A. fernandezianum Joh.; Johow, Estud. Ior ; Skottsberg, Stud. i7, Taf. 5 Fig. 6.

Masatierra: Tres Puntas (JoHow); barren cliffs in B. del Padre (fr. ${ }^{15} / 1$ I 7 , no. 291 ; beg. fl. $6 / 8$ 17, BÄCKSTRÖM no. $29 \mathrm{I}$ b; also observed by JOHOW and by the writer, 1908); Tierras Blancas (fl. $6 / 8$ I7, BÄcksTRÖM no. 1 219).

Cultivated in a temperate house this species develops exceedingly well and flowers and fruits freely. The branches, which are decumbent and root at the nodes, attain a length of one nieter. The fruit is typical of the genus and agrees with that of $A$. graveolens in structure. A. fernandezianum is related to A. prostratum Labill,, widely dispersed in the Southern Hemisphere; it differs above all in the shape and cutting of the leaves.

Area of distribution: Endemic in Masatierra.

\section{Ericaceae.}

\section{Pernettya Gaud.}

91. P. rigida (Bert.) DC. - JoHOW, Estud. 87.

Masatierra: Generally outside the forest but rare below the wooded region; one of the most important shrubs on the rocky ridges, where it forms low thickets. It does not, however, thrive well in the dry western section. We found it on all the ridges to the highest altitude reached (c. $800 \mathrm{~m}$ ), and I am sure it is a leading species on the top of the Yunque. - Fl. $3 / 12$ I6, no. 27; 
$8 / 12$ I6, no: $89 ; 1 / 117$, no. $259 ;$ fr. $17 / 4$ I7, no. 623 . - A form with larger and thinner leaves was collected at the edge of the Dicksonia-forest on C. Salsipuedes (buds $8 / 1216$, no. 77), another with exceptionally narrow leaves among rocks near this place (f. $8 / 1216$, no. 86 ).

Masafuera: Scattered in the higher parts, locally abundant. Ridges and plains above the Chozas village, $600-\mathrm{I} 350 \mathrm{~m}$ (fl. ${ }^{15} / 2 \mathrm{I} 7$, no. 490); slopes of Los Inocentes, $480--1400 \mathrm{~m}$, not uncommon.

Area of distribution: Endemic.

\section{Convolvulaceae.}

\section{Dichondra Forst.}

"92. D. repens Forst.

Masatierra: Pto Frances, by the stream, c. $40 \mathrm{~m}$.

Masafuera: Outer part of $Q$. de las Casas, among grass (fr. ${ }^{27 / 2}$ I7, no. 551 ).

New for Juan Fermandez. A rather typical D. repens; the young leaves are sericeous, the older sparingly pubescent below and glabrous above, the peduncles $2 \mathrm{~cm}$ long or even longer. Compare HALLIER in ENGLER's Jahrb. XVIII (I892) 83. ReICHE, Fl. de Chile V. 173 includes all forms under D.repens Forst.

I suspect this to have been collected by Bertero, for Montagne, Prodr. F1. Fern. 356 enumerates „Uredo Hydrocotyles Bert. Hab. ad folia Hydrocotyles?» No Hydrocotyle has ever been reported from the islands; sterile Dichondra may perhaps be mistaken for a species of that genus.

Area of distribution: Subcosmopolitan (Eastern Asia, India, Africa, Mascarene Islands, Australia, New Zealand, North and Central America, South America to Patagonia and Chile, Juan Fernandez).

\section{Calystegia R. Br.}

93. C. tuguriorum R. Br. - Syn. C. Hantelmanni Phil., JoHow, Estud. 85. Masafuera: $Q$. de las Casas (no. 412, also observed by JoHow); Q. de las Vacas, abundant in the outer part; Q. del Varadero. Forming dense carpets on the canyon walls.

Both J. D. Hooker and Hemsley united C. Hantelmanni with C. nuguriorum, but JoHOW kept them separate, declaring that the latter is a small herb, not attaining the size of C. scpizun. However, Chesseman, Man. N. Z. Flora 476 states that the stem is slender, prostrate or climbing, often clothing trees and shrubs to a considerable height. During his monographical studies HALIIER came to the conclusion that the two species are identical [ENGLER's Jahrb. XVI (1893) 548], and I have found it better to follow him.

Area of distribution: New Zealand; Chatham Islands; South Chile (Valdivia); Masafuera. 


\section{Boraginaceae.}

\section{Selkirkia Hemsl.}

\section{S. Berterii (Colla) Hemsl. - JoHow, Estud. 85.}

Masatierra: On the steep rocky slopes above the forests in the centre of the island, rare. Co Damajuana, $500-550 \mathrm{~m}$, very rare; the gap between Damajuana and $C_{0}$ Yunque, $580 \mathrm{~m}$, few specimens (past fl. $18 / 12$ 16, no. 132); northwest face of Co Pirámide, narrow rock ledge, c. $600 \mathrm{~m}$, few shrubs; Portezuelo de Villagra, near the pass (also observed by JoHOW), a couple of specimens, $570 \mathrm{~m} ; \mathrm{Q}$. del Monte Maderugo, rock wall $390 \mathrm{~m}$, rare (past f. ${ }^{24} / 1$ 17, no. 341 ).

Area of distribution: Endemic in Masatierra; monotypic.

\section{Verbenaceae.}

\section{Rhaphithamnus Miers.}

95. Rh. venustus (Phil.) Skottsb. - Syn. Citharexylon venustum Phil. Anal. Univ. 1856; Rh. longiflomes Miers, Trans. Linn. Soc. XXVII (1870) 98; JoHow, Estud. 78 .

Masatierra: in the wooded region, extending from Pto Frances to the south slope of Co Chumacera, hardly ever seen below $200 \mathrm{~m}$ and much more common higher up; also in the shrubberies on the ridges. Fl. ${ }^{3} / 1216$, no. 11 ; $7 / 12$ I6, no. $40 ;{ }^{28} / 12$ I6, no. $198 ;$ fr. ${ }^{21} / 4$ I7, no. $625,{ }^{24} / 417$, no. Il b. - A form with red flowers was found near Plazoleta del Yunque, c. $250 \mathrm{~m}$.

Masafuera: GUAJARDO without locality. - In the forests, much more scarce than in Masatierra; on the. Sanchez plain, $515 \mathrm{~m}$; Q. del Mono, $475 \mathrm{~m}$; Q. del Blindado, $440 \mathrm{~m}$ (fl.-fr. ${ }^{19 / 2}$ I7, no. 5 I6).

Area of distribution: Endemic.

\section{Labiatae.}

\section{Cuminia Colla.}

While HemsLeY, Challenger Report 5 I lists three species, eriantha, feruandezia and brevidens, JoHow reduces brevidens to fernandezia. I have seen the material on which $C$. brevidens was based by BENTHAM, and I think that JoHOW is right. The length of the calyx lobes is submitted to some variation; I admit that they are very short in $C$. brevidens, but otherwise no perceptible difference is found.

HEMSLEY ascribed unisexual flowers to Cuminia, Johow denied the correctness of this statement and suggested that HEMSLEY was misled by the pronounced dichogamy of the flowers. My examination of numerous living 
specimens shows that there are two kinds of flowers, differing in size and in development of the anthers. Female flowers have shorter corolla, exserted style and small staminodes, bisexual flowers have a larger corolla, included style and normal stamens. I believe there are specimens with one kind only, but others exhibit both kinds in the same inflorescence. Flowers with perfect anthers were called male by HemsLey. There does not, however, seem to be any difference in the style or stigma between them and the female flowers. Still I have observed cases where the former were shed soon after they had opened. In a few cases female flowers with one or two fertile stamens were met with.

JoHow's statement that Cuminia absolutely lacks "esencias etéreas» is not in accordance with my experience, for $C$. eriantha at least, has a weak but unmistakable labiatoid smell.

96. C. fernandezia Colla. - JoHow, Estud. 81. - Fig. 22.

Masatierra: In the open forests of the ridges and along the rocky crests, never abundant and only once observed below $300 \mathrm{~m}$. - Between $\mathrm{Q}$. de la
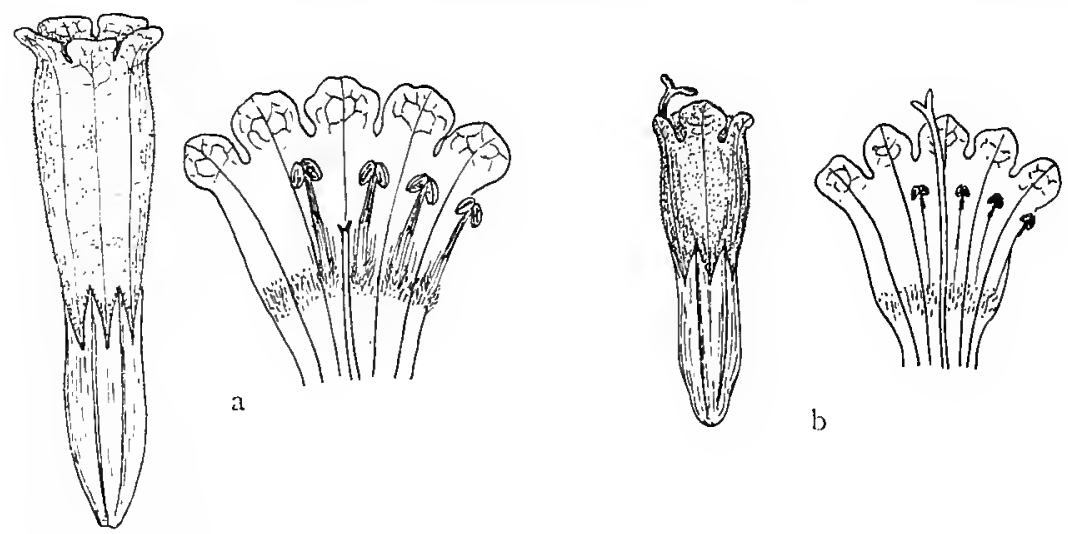

Fig. 22. Cuminia fernandezia: a male or bisexual, b female flower, with limbs slit open to show stamens and staminodes. $\times 4$.

Piedra Agujereada and Q. Laura (f. magis pilosa); in the higher parts of El Rabanal (also quoted by JoHow; f. ${ }^{28 / 3}$ 17, no. 576 , f. magis pilosa); slopes of Co Damajuana, 350-530 m; V. Colonial, C. Central (A. ${ }^{18} / 1$ I7, no. 307); Portezuelo de Villagra (also observed by JOHOw), 540--590 m, scarce (beg. fl. 25/12 I6, no. I92, fr. ${ }^{31 / 3}$ I 7 , no. I92 b); Q. del Monte Maderugo, rocky ridge, $390-500 \mathrm{~m}$; C. Salsipuedes (also observed by JOHOw) $400-625 \mathrm{~m}$, not uncomnion (beg. fl. ${ }^{20 / 12}$ I6, no. I65); Pto Ingles, central ridge, $570 \mathrm{~m}$; between La Vaquería and $Q$. Juanango, c. $300 \mathrm{~m}$; ridge west of Co Yunque, c. $550 \mathrm{~m}$; low hill near the camping place in B. Villagra, c. $200 \mathrm{~m}$ (fl. $7 / 1$ I 7, no. 234); Co Chumacera, south slope (fl. $\% 117$, no. 356 ).

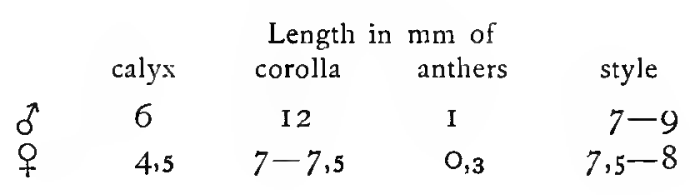


Generally perfectly glabrous save for the corolla and some hairs on the calyx lobes. The young leaves are, however, more or less pubescent. No. 576 differs from ordinary fernandesia in the persistent indumentum on petiole, nerves and pedicels, a character otherwise attributed to eriantha only. This species has larger and broader leaves of a more dull green colour, light violet to nearly white corolla with almost white lobes and filaments, while the flowers of fernandesia are of a bright blue lilac colour.

Area of distribution: Endemic in Masatierra; the genus is endemic.

97. C. eriantha Benth. - JoHow, Estud. 82.

Masatierra: with the former, but much more scarce. Between $Q$. de la Piedra Agujereada and Q. Laura, c. 500; El Rabanal (JoHow); V. Colonial, C. Central, c. $500 \mathrm{~m}$; Portezuelo, on the Villagra side in forest (also observed by JoHow), c. $500 \mathrm{~m}$, rare (fl. ${ }^{10} / 1 \mathrm{I} 7$, no. 278 ); C. Salsipuedes (also JoHow), in Dicksonia-grove, $660 \mathrm{~m}$, rare (fl. $13 / 117$, no. 282).

\begin{tabular}{|c|c|c|c|c|}
\hline & calyx & $\begin{array}{l}\text { Lengtl } \\
\text { corolla }\end{array}$ & $\begin{array}{l}\mathrm{mm} \text { of } \\
\text { anthers }\end{array}$ & style \\
\hline 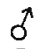 & 7 & I $2-$ I 3 & 0,75 & $7-9$ \\
\hline q & 5 & $8-9$ & 0,3 & $7-8$ \\
\hline
\end{tabular}

Area of distribution: Endemic in Masatierra.

Solanaceae.

\section{Solanum L.}

98. S. fernandezianum Phil. - JoHow, Estud. 82.

Masatierra: BERTERo! GERMAIN! - In the wooded region, in moist humus, very local. Pto Frances (JoHow); C. Chifladores, near the Frances Valley; El Rabanal, in the valley; Northeast slope of Co Damajuana, c. $500 \mathrm{~m}$; V. Colonial, $Q$. del Monte Maderugo, $235 \mathrm{~m}$ (fl.-unr. fr. ${ }^{24} / 1 \mathrm{I} 7$, no. 340); forest on the east slope of C. Salsipuedes, c. $350 \mathrm{~m}$; Pto Ingles (also quoted by Jorrow), central ridge, $470 \mathrm{~m}$; Q. Villagra, near the road just below the pass, c. $550 \mathrm{~m}$ (f. ${ }^{3} / 12,{ }^{24} / 1$ g I6, no. I2, fr. April I9I7; beg. fl. ${ }^{31} / 7$ I7, В ̈̈скSTRÖм no. I2 b).

The species was described as lacking tubers, but on BERTERo's label is written »tubercula gustu amaro». This is very puzzling, for JoHow could not find the tubers, nor were we able to discover any. In order to find out if they develop during the winter, I told Mr. BÄCKSTRÖM to dig for them, but he could not find them. I have raised several specimens from seeds; they have flowered and fruited, but behave like annuals and do not form any tubers. I have propagated them from cuttings, using the basal axillary shoots. In a wild state the plant branches profusely and seems to be perennial.

Area of distribution: Endemic in Masatierra.

99. S. Robinsonianum Bitter in FEDDE's Repert. XI (I9I2), 7. - Syn. S. furcatum, JoHow, Estud. 83. 
Masatierra: Philipf I 864! - El Rabanal (JoHOw); Pto Ingles, west branch, $190 \mathrm{~m}$ (fl.fr. ${ }^{20} / 1$ I7, no. $3 \mathrm{I} 1$ ); B. Villagra, ravine near the campingplace, c. I $80 \mathrm{~m}$ (fl.-fr. ${ }^{7} / 1$ I 7 , no. 260 ).

Santa Clara: Jonow. - Morro de los Alelíes, rare (f.-fr. ${ }^{26} / 1$ I 7, no. 343).

*Masafuera: near the Chozas village (f. 12/2 I7, no. 506); Q. del Varadero (fl. fr. ${ }^{12 / 3}$ I 7 , no. 508). - New for this island.

Professor BITTER kindly examined my dried material as well as living plants raised fron my seeds and communicates the following new description:

"Addenda ad descriptionem:

Herbaceum, rectum, ca. $40-60 \mathrm{~cm}$ altum, divaricatim ramosum; rami ca. $4 \mathrm{~mm}$ diam., obtuse angulati, lineis decurrentibus parum prominentibus instructi, pilis simplicibus pluricellularibus acutis curvatinı accumbentibus primo crebris serius sparsioribus obsiti; internodia in ramis florentibus $5-8 \mathrm{~cm}$ longa; folia superiora false geminata, inaequalia; petioli $1,5-2 \mathrm{~cm}$ longi, jam a basi vel fere a medio sensim latius alati; laminae ovatae vel late ovati-lanceolatae, najores $8,5: 5,9-9,5: 5,5-6$ usque ad $14: 8,5 \mathrm{~cm}$, minores $5: 3,6: 3,7,7: 4,7,5: 4,5 \mathrm{~cm}$, basi late cuneatim vel subrotundatim in petiolum alatum abeuntes, infra medium latissimae, ad apicem versus magis sensim angustatae, subacutae vel obtusiusculae, dentibus grossis late triangularibus in utroque latere ca. 5-- 7 obtusis vel obtusissimis instructae, membranaceae, utrinque virides, subtus vix pallidiores nitidioresque, utrinque praecipue in venis, sparsius in mesophyllo pilis simplicibus acutis pluricellularibus curvatim accumbentibus crebris obsitae; vena media et venae later. prim. in utroque latere $7-8$ (raro 9-11) curvatim ascendentes subtus prominentes; inflorescentiae laterales, a foliis remotae, 7-I I-florae; pedunculus $12-25 \mathrm{~mm}$ (tandem $-27 \mathrm{~mm}$ ), longus, semel furcatus; rhachides cr. 6 -(tandenı)9 $\mathrm{mm}$ longae, flores plerumque densiuscule in rhachidum apicibus secuti; pedicelli 5-I I mm longi, in statu florifero erecti; calyx campanulatus, cr. $4: 3 \mathrm{~nm}$, profunde in lobos lineari-lanceolatos acutos inaequilongos (exteriore ceteris longiore) $2--3: 0,8 \mathrm{~mm}$ partitus, extus sicut pedunculus, rhachides et pedicelli pilis brevibus simplicibus pluricellularibus acutis accumbentibus praeditus, intus praecipue in parte connata glandulis minutis breviter stipitatis crebris obsitus; corolla stellata, diam. I 5- 7 mm, extus violacei-suffusa, ceterum albida, in parte interiore stella flavescente striis tenuibus obscuris (fusci-violaceis) radiantibus insignata, profunde in lobos lanceolatos acutos $8: 2,5 \mathrm{~mm}$ extus pilis simplicibus acutis brevibus crebris obsitos intus pilis brevibus similibus in vena media tantum sparsis, in parte apicali crebris praeditos partita; filamenta paulum inaequilonga, $1,5-2 \mathrm{~mm}$ longa, gracilia, intus pilis pluricellularibus simplicibus vel rarius semel ramosis acutis densis instructa; antherae anguste ellipsoideae, $3: 0,8 \mathrm{~mm}$, utrinque emarginatae, poris introrsis subapicalibus obliquis; ovarium subglobosum, I mm diam., glabrum; stylus stanina manifeste superans, $6 \mathrm{~mm}$ longus, fere a basi $\mathrm{cr} .{ }^{2} / 3$ longitudinis pilis densis simplicibus pluricellularibus acutis sensim minoribus patentibus obsitus; stigma styli apice paulum crassius, obtusum, subbilobum; calyx in statu fructifero auctus, diam. $7-8 \mathrm{~mm}$, lobis latius lanceolatis cr. $3-4: 2$ mın subacutis vel obtusiusculis baccae accumbentibus; baccae maturae globosae, non satis magnae, ca. $5-8 \mathrm{~mm}$ diam., parum nitidae, tandem nigerrimae, succo intense purpurei-violaceo impletae; granula 
sclerotica duo subapicalia subglobosa parva, ca. 0,6 mm diam.; semina ca. $15-16$, oblique reniformia, valde applanata, I,6-1,8:I-I,3:0,5 $\mathrm{mm}$, manifeste minute reticulata, in baccis maturis extus succo violaceo intense tincta.»

Area of distribution: Endemic.

* 1oo. S. (Morella) masafueranum Bitter et Skottsb. nov. spec. - Plate I4.

The following description was written by Professor BITTER.

Herbaceum, ad I,75 $\mathrm{m}$ altum; rami robusti, \pm ve flexuosi, 4-6 mm diam., subteretes vel paulum obtnse angulati, lineis decurrentibus parum prominentibus instructi, pilis simplicibus pluricellularibus acutis parvis diaphanis curvatim accumbentibus plerumque sparsis obsiti, tandem subglabrescentes; internodia in ramis majoribus elongatioribus 9-I4 cm longa; folia solitaria vel superiora saepe false geminata, tunc inaequalia; petioli $\mathrm{I}, 5-4 \mathrm{~cm}$ longi, ad laminam versus sensim magis alati, pilis simplicibns pluricellularibus acutis parvis crebris obsiti; laminae late oblique lanceolatae vel oblongi-lanceolatae, infra medium latissimae, basi oblique cuneatim vel rotundatim in petiolum alatum abeuntes, ad apicem versus magis sensim angustatae, acutae vel fere sensim acuminatae, integrae, majores $\mathrm{cr}$. I $2: 5$, I $5: 6$ usque ad $17,5: 7 \mathrm{~cm}$ (an etiam majores?), minores $9: 3,3$ usque ad $12: 4,5 \mathrm{~cm}$, laminae omnes herbaceae, utrinque sordide virides, subtus paulum pallidiores nitidioresque, utrinque in venis et in mesophyllo pilis simplicibus pluricellularibus acutis sparsis, in margine paulo densioribus obsitae; vena media, venae later. prim. 6 curvatim ascendentes et venae later. secund. illas reticulatim conjungentes albide flavescentes subtus prominentes; venae majores subtus sicut petioli et rami in statu sicco striolis brevissimis parum prominentibus densis praeditae (cellulae arena crystallina impletae!); inflorescentiae laterales, extraaxillares, fere semper paulum infra nodos ortae, simplices vel semel breviter furcatae, 5-8-florae; pedinculus $I, 5-$ (tandem in statu fructifero!) $3 \mathrm{~cm}$ longus, rhachides 4-6 $\mathrm{mm}$ tantum longae, floribus ergo densiuscule secutis ; pedicelli in statu florifero erecti, $6 \mathrm{~mm}$ longi, in statu fructifero basi deflexi, IO-I I mm longi; calyx campanulatus, $3 \mathrm{mn}$ longus, apice fere $3 \mathrm{~mm}$ diam., in dentes 5 ovati-lanceolatos obtusiusculos $\mathrm{Imm}$ longos $0,5 \mathrm{~mm}$ latos basi membranis diaphanis conjunctos partitus, extus sicut pedunculus, rhachis et pedicelli pilis pancicellularibus acutis curvatim accumbentibus densiusculis obtectus, intus glandulis minutis breviter stipitatis crebris obsitus; corolla alba, stellata, diam. Io--14 mm, in lobos 5 lanceolatos acutiusculos $\mathrm{cr} .5: 3 \mathrm{~mm}$ extus pilis simplicibus paucicellularibus acutis accumbentibus crebris in parte apicali densis et partim subramosis obtectos, intus in venae mediae parte superiore et in mesophylli parte apicali pilis simplicibus paucicellularibus obsitos partita; corollae tubus infra staminum insertiones cr. 1,5 mm longus, glaber; filamenta 1,5 -(tandem) $2 \mathrm{~mm}$ longa, intus (praecipue prope basim) pilis simplicibus pluricellularibus acutis densis ad apicem versus sensim sparsioribus praedita; antherae flavescentes, ellipsoideae, utrinque emarginatae, cr. 2,2:0,8-1 $\mathrm{mm}$, poris introrsis apicalibus obljquis tandem paulum longitudinaliter dehiscentibus; ovarium subglobosum, I mm diam., glabrum; stylus 5,5-6 $\mathrm{mm}$ longus, in parte apicali subgeniculatim incurvatus, paulo supra basim glabram cr. ${ }^{2} / 3$ longitudinis pilis tenuibus patentibus fere omnibus simplicibus (perpaucis semel subramosis) pluricellularibus acutis densis sensim minoribus obtectus, in parte apicali glaber; 
stigma subglobosum, styli apice manifeste crassius; calyces fructiferi parum aucti, diam. cr. $5 \mathrm{~mm}$, lobis magis triangularibus baccae submaturae accumbentibus; baccae submaturae globosae, $6-8 \mathrm{~mm}$ diam.; semina oblique reniformia, valde applanata, $2: 1,5: 0,5 \mathrm{~mm}$, minute reticulata; granula sclerotica in bacca non reperi.

Masafuera: In forests. On the Sanchez plain, $515 \mathrm{~m}\left(\mathrm{fl} .{ }^{25} / 217\right.$, no. 526); near the Chozas village (fl.-unr. fr. ${ }^{3} / 3$ I 7 , no. 363 ).

Area of distribution: Endemic in Masafuera.

\section{Nicotiana L.}

101. N. cordifolia Phil. - Johow, Est. 83; Skottsberg, Stud. 7, Taf. 6 Fig. 4 .

Masafuera: Coast cliffs close to the landing place near $Q$. de las Casas (fl. ${ }^{10} / 2$ 17, no. 1220); $Q$. de las Vacas, on the canyon wall, not far from the entrance, scattered specimens (also observed by JoHOw and by the writer in 1908, only locality known hitherto; fl.fr. ${ }^{10} / 2$ 17, no. 392); Q. Angosta, in the gorge; $Q$. del Varadero, numerous fine shrubs near the entrance; along the shore of Tierras Blancas, not uncommon (fl.fr. ${ }^{17} / 2$ 17, no. 399).

Area of distribution: Endemic in Masafuera.

\section{Scrophulariaceae.}

\section{Mimulus L.}

102. M. parviflorus Lindl. - JoHow, Estud. 82.

var. externa nov. var. - A plantis in Chile lectis differt foliis omnibus petiolatis (superioribus brevius sed semper distincte), margine sat grosse et irregulariter serratis, nec non pedunculis petiolum aequantibus sed foliis multum brevioribus. Planta perennis pilosa.

Masafuera: GERMAIN! - Q. de las Casas (also observed by JoHow), wet places under overhanging rocks etc.; $Q$. de las Vacas (fr. ${ }^{18} / 2$ 17, no. 497); Q. Angosta, at the waterfall; $Q$. de la Lobería (fl.-fr. $17 / 217$, no. 486).

It is hardly possible to ascertain the right position of the insular form unless all the material from the continent is revised. GERMaxn's specimens were labelled $M$. parviflorus var. by PHILIPPI, and JOHOw remarks that the Masafueran plant differs from the continental one in the short pedicels and in the pubescence. As all specimens collected in Masafuera are of the same kind, while there is no similar form in the collections from Chile, I have described the former as a variety. It is not impossible that $M$. pilosiusculus Kunth from Perú is the same, but as I have not seen authentic material and the description is very brief, I must leave this question open.

Area of distribution: $M$. parviflorus is common in central and south Chile. 


\section{Euphrasia L.}

"IO3. E. formosissima nov. spec. - Plate I5, fig. I, Plate 20, fig. 6-7; text fig. 23.

Eueuphrasia pluriennis lignosa, plerumque $15-20$, interdun usque ad $70 \mathrm{~cm}$ alta, ad radices Pernettyae rigidae parasitica. Truncus primarius cylindricotetragonus, ad $6 \mathrm{~mm}$ crassus, cortice obscure fusco inferne glabrato, fere a basi opposite ramosus, ramis ramulosis ramulis iterum ramosis, junioribus distinctius tetragonis bifariam hirsutis, pilis crassis plerumque bicellularibus. Folia carno. sula late - anguste ovata, $8-$ I 8 (rarius ad 20 et ultra) $\mathrm{mm}$ longa et $5-8 \mathrm{~mm}$ lata, basi in petiolum $2-3 \mathrm{~mm}$ longum subiter vel sensitn angustata, margine leviter revoluta dentibus humilibus latissime truncatis utrinque $3-5$ (plerumque 4 ) instructa, supra subglabra, parcissime glandulosa sed secus nervos pilosiuscula, subtus in parte inferiore ad nervos parce pilosa vel subglabra, infra marginem et inter nervos incrassatos reticulo glandularum humilium capite ferrugineo pulchre notata. Bracteae quam folia caulina minores ac latiores. Flores ad apicem caulis ramorumque breviter sed densiuscule spicati, sessiles. Calyx pro genere sat typicus, lobis lineari-subspathulatis apice incrassatis, extus nervis exceptis subglaber, intus secus nervos pilosus pilis unicellularibus et glandulis ferrugineis commixtis, 5-6 mm longus, profunde partitus. Corolla alba 1O-I 3 $\mathrm{mm}$ longa, tubo $4-5 \mathrm{~mm}$ longo ad finem anthesis haud elongato, subglabro, intus inferne obscure luteo; labium superius extus pilosum, $6-7 \mathrm{~mm}$ longum et 5--6 latum, bifidum lobulis reflexis; labium inferius glabrum 7-8 $\mathrm{mm}$ longum et ad IO-I I mm latum, in centro macula magna flavo-aurantiaca distincte circumscripta notatum. Filamenta staminum posticorum sub $3 \mathrm{~mm}$, anticorum circ. $3,5 \mathrm{~mm}$ longa, inferne lutea, dein viridescentia, antherae ad $I_{4} \mathrm{~mm}$ longae, ferrugineae, subglabrae-glabrae, duorum staminum posticorum loculus unus paulo longius calcaratus. Stylus ad $9 \mathrm{~mm}$ longus, dilute viridis, parce pilosus, exsertus; stigma alboviride capitatum. Capsula matura valvis obovatis minute emarginatis et abrupte apiculatis, superne setulosa, $2,8-3 \mathrm{~mm}$ longa et $2-2, \mathrm{~mm}$ lata. Semina oblique fusiformia $I-I, 2 \mathrm{~mm}$ longa straminea, testa longitudinaliter sulcata et inter juga transverse sculpta.

Masafuera: in the higher parts, not uncommon in the alpine region. Ridges above $Q$. Sanchez (fl. ${ }^{25} / 217$, no. $386 \mathrm{~b}$ ); north of the Casas gorge from 800 to $1400 \mathrm{~m}$ (f..fr. ${ }^{14} / 2-7 / 3$ 17, no. 386); C. Atravesado, common; C. del Barril, from $750 \mathrm{~m}$ (f. $1 / 3 \mathrm{I}$, no. 547 ).

A rather interesting discovery. Two types of Euphrasia are known from the southern hemisphere, sect. Trifidae from Chile and sect. Eueuphrasia subsect. Australes from Australia and New Zealand. The new species has nothing to do with the South American species, and as far as I can see, it is not nearly related to the Australes, but belongs to the Semicalcaratae, known before only from the northern hemisphere. Within this section $E$. formosissima is the only perennial species. Among boreal ones it might be compared with $E$. grandiflora Hochst. (Azores), or with species from Eastern Asia. It lies near at hand to regard it as one of the older endemics in the islands, as it differs 
from all other species in its mode of growth (see below) and as it stands so far apart from all the congeners on the south hemisphere.

The arrangement of the glands on the lower leaf surface is illustrated in fig. 23 b. These glands are of two kinds, smaller with a short, narrow, unicellular stalk and a globose two-celled head with dark brown contents and larger (much less numerous), sessile, like a semiglobose papilla, divided by a radial wall and with yellowish contents. Both kinds were described by WETT. STEIN in his monograph of the genus, p. 18-19. The long pedicellate glands so common in many other species seem to be wanting. The smaller kind also occurs on the upper side of the leaf and on the calyx.
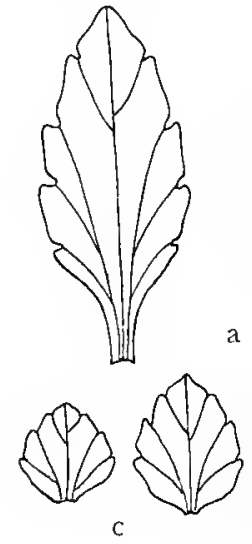

C
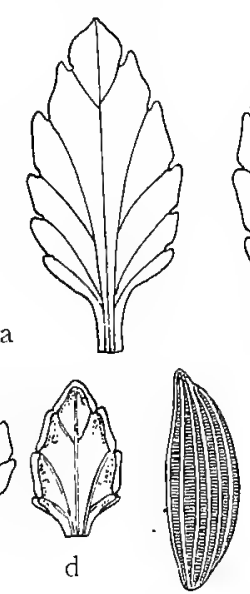

l)
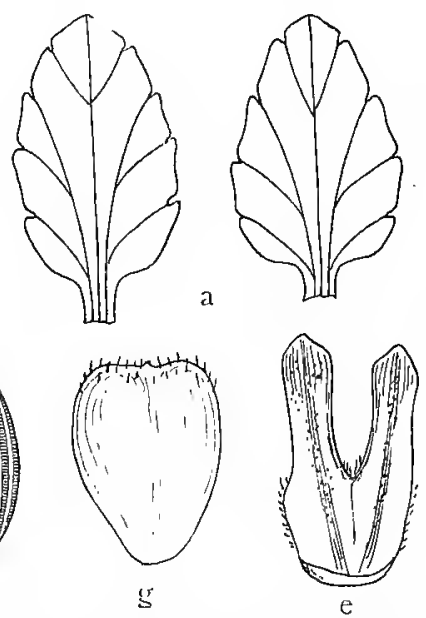

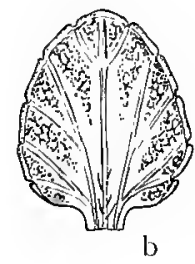

b

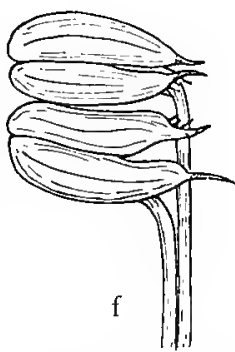

Fig. 23. Euphrasia formosissima: a leaves, showing general outline, b lower side of leaf, c bracts, d lower side of bract, a-d $\times 2$; e two calyx lobes, inside, $X 4$; $f$ stamens, $X$ I $2 \frac{1}{2}$; g capsule, $\times 6,6 ; \mathbf{h}$ seed, $\times 20$.

The growth of other perennial Euphrasiae was explained by WETTSTEIN 1. c. I4. The shoots die off after hawing produced flowers, while lateral branches, which are sterile the first season, becone floriferous the next year, and so forth. E. formosissima represents another type. To some extent it is like many others, for the primary stem and a number of side branches may produce flowers simultaneously, sometimes even a few shoots of a third generation flower at the same time. It occurs that a branch dies after having flowered, but very often this is not the case: the branch survives, the top continues to grow above the floral region and produces a new set of flowers, and this may be repeated again; thus, the new species differs from all others. If, as WETTSTEIN thinks, the perennial species are genetically older than the annual, E. formosissima seems to exhibit the most primitive type of Euphrasia known.

Area of distribution: Endemic in Masafuera. 


\section{Plantaginaceae.}

\section{Plantago L.}

104. P. fermandezia Bert. - JoHow, Estud. 77.

Masatierra: In the shrubberies along the high ridges in the centre of the island, rare. North face of Co Damajuana, $530 \mathrm{~m}$, few specimens; the depression between this peak and Co Yunque, $580 \mathrm{~m}$, rare; V. Colonial, C. Central, $570 \mathrm{~m}$, very few plants; Portezuelo de Villagra, c. $550 \mathrm{~m}$, near the path in two places, perhaps twenty specimens altogether (fl. ${ }^{3-25} / 12 \quad 16$, no. 7 ; only locality known before, JoHow etc.) rock ledges on the perpendicular wall of Co Pirámide, c. $575 \mathrm{~m}$.

Professor PILGER sent me the following notes on this species:

»P. fernandezia ist mit P. princeps Cham. et Schlecht. von den HawaiiInseln verwandt: sie ist dieser Art nicht nur habituell ähnlich, sondern zeigt auch grosse Übereinstimmung im Blütenbau. Für eine entferntere Verwandtschaft könnten auf dem amerikanischen Festland höchstens einige Arten der Cleistantha-Gruppe (P. Candollei, oreades, Sodiroana) in Betracht kommen.

Zwei Blütenstände der Exemplare von P. fernandezia zeigen eine mehr oder weniger weitgehende Verkümmerung der Staubblätter. Die nornale Form hat Bliiten mit lang herausragenden Antheren. $\mathrm{Zu}$ dieser Form sind Übergänge vorhanden, indem die Antheren etwas zwischen den dauernd aufrechten Corollenzipfeln sich hervordrängen und \pm reichlich Pollen entwickeln. In anderen Blüten bleiben die Antheren von den aufrechten Zipfeln umschlossen, sie sind ziemlich gross, entwickeln aber keinen Pollen. Der Griffel ragt aus der Blüte hervor. Man könnte an einen Vergleich mit dem Dimorphismus bei der Cleistantha-Gruppe denken, doch ist der Fruchtknoten in den Blüten mit reduzierten Staubblättern nicht stark entwickelt wie dort bei den geschlossenen Blüten, sondern bleibt klein und von der Röhre frei.»

Area of distribution: Endemic in Masatierra.

105. P. truncata Cham. subsp. Skottsbergii Pilger. - P. Skottsbergii Pilger in SrotTsberg, Stud. 6.

Masatierra: B. del Padre (Skottsberg 1908).

*Santa Clara: scattered on the table-land (fr. ${ }^{26} / 1$ 17, no. 350 ).

Professor PILGER remarks to this species: $\gg$ P. Skottsbergii ist eine charakteristische Form, die allerdings der P. truncata subsp. firma sehr nahe steht. Am besten wird man sie neben P. firma auch als subspecies zu P. truncata stellen».

Area of distribution: $P$. truncata is known from Central and South Chile, the subspecies is endemic in Masatierra and Santa Clara.

Rubiaceae.

\section{Oldenlandia L.}

* Io6. O. thesiifolia K. Schum. - Syn. O. uniflora Ruiz. et Pav. non L. Masatierra: V. Colonial, in the small stream at the foot of the chapel hill. 
Rather like Schumann's illustration in Flora Brasil. VI: 6, tab. 127. Agrees very well with specimens from Chile. Glabrous with few hairs on the ovary.

Undoubtedly of recent introduction, as it has not been recorded by previous visitors in spite of growing in Cumberland Bay. There is perhaps no reason to regard it as introduced with the human traffic; the valley is sometimes visited by stray birds from the continent, and they very likely brought seeds of this and some other species in mud adhering to their feet.

Area of distribution: Brazil, Argentina, Paraguay, Uruguay, Chile from Valparaiso to Chiloé, Masatierra.

\section{Nertera Banlss et Sol.}

I07. N. depressa Banks et Sol. - Skotrsberg, Stud. 6.

Masafuera: almost confined to the subalpine and alpine districts, where it occurs in moist places, round large stones, in small depressions in the ground etc., generally associated with mosses. - Q. de las Casas, in wet moss at the waterfall, $215 \mathrm{~m}$; high land north of Casas, not uncommon from 750 to about I $100 \mathrm{~m}($ fr. $12 / 2 \mathrm{I} 7$, no. $4 \mathrm{I} 3,25 / 2 \mathrm{I} 7$, no. $413 \mathrm{c})$; among rocks at Las Torres, I $370 \mathrm{~m}$ (fl.-fr. no. 4I3 b); C. del Barril, 650-750 m.

Area of distribution: Mexico to Fuegia; subantarctic-circumpolar; Hawaii; Masafuera.

\section{Coprosma Forst.}

108. C. triflorum (Hook, et Arn.) Benth. et Hook. f. -- JoHow, Est. 73. Fig. $24 \mathrm{a}-\mathrm{c}$.

Masatierra: in the open forest and in the shrubberies along the ridges, not uncommon from $3-400 \mathrm{~m}$, ascending to the highest peaks and ranging from Pto Frances to Co Chumacera. Fl. of 14/12 16, no. 26, 17/12 16, no. 150 ; fl. ${ }^{17} / 1216$, no. 151 (a few fruits from 1916 still on the trees); past fl. $q$ $4 / 1$ I7, no. $235 ;$ fr. ${ }^{28} / 3$ I 7 , no. $570,{ }^{11} / 1$ I7, no. 6 II.

Mistaken for Hippotis triftora Ruiz. et Pav. by BERTERo, Ann. sc. nat. XXI. 347; called Psychotriar triflora Hook. et Arn., Bot. Misc. III. 359, P. Hookeri $G$. Don Gen. Syst. Gard. III. 585. The flowers have not been described, but Bentham and Hooker FIL. recognized it as a member of the genus Coprosma, Gen. plant. II. I 39.

Generally strictly dioecious. Corolla of $\delta^{\lambda} 6-7 \mathrm{~mm}$ long, fleshy, greenish brown, as a rule 4 -cleft; 4 stamens with thin filaments, $6-7 \mathrm{~mm}$ long, anthers 4,5-5 $\mathrm{mm}$ with thick, brown connective. Female flowers with $2,5 \mathrm{~mm}$ long ovary; corolla dark lilac brown with narrow tube measuring $2-3 \mathrm{~mm}$ and four strongly revolute narrow linear segments, $2-2,5 \mathrm{~mm}$ long. Styles white, $9 \mathrm{~mm}$ long.

In one case a number of bisexual flowers were found on a branch of a female tree. They have a large, normal ovary with the usual long styles. The corolla is more as in the male flower, but only 4-.5 mm long; there are 4 stamens with $2,5 \mathrm{~mm}$ long anthers but very short filaments. The pollen contained numerous sterile grains. 
Very like $C$. foliosum A. Gray from Oahu (Hawaii), which differs in the narrower leaves and in the shape of corolla and stamens.

Area of distribution: Endemic in Masatierra.

I09. C. pyrifolium (Hook, et Arn.) Skottsb. - Syn. Psychotria pyrifolia Hook. et Arn., JoHow, Estud. 74. - Fig. 24 d.

Masatierra: An important forest tree, extending over the entire wooded region from Pto Frances to Co Chumacera and ranging from $200 \mathrm{~m}$, or perhaps less, to $650 \mathrm{~m}$ at least. We did not find flowering specimens (sterile, $18 / 12 \mathrm{I} 6$, no. I6I, ${ }^{20} / 12$ I 6 , no. $1222,18 / 1 \mathrm{I} 7$, no. 308 ); but ripe fruits were gathered $9 / 4 \mathrm{I} 7$, no. 600 .

Masafuera: Scattered through the forested region; lowest altitude observed $280 \mathrm{~m} \mathrm{(fr.}{ }^{17} / 2 \mathrm{17}$, no. 435 ); not uncommon up to $950 \mathrm{~m}$. One small tree was
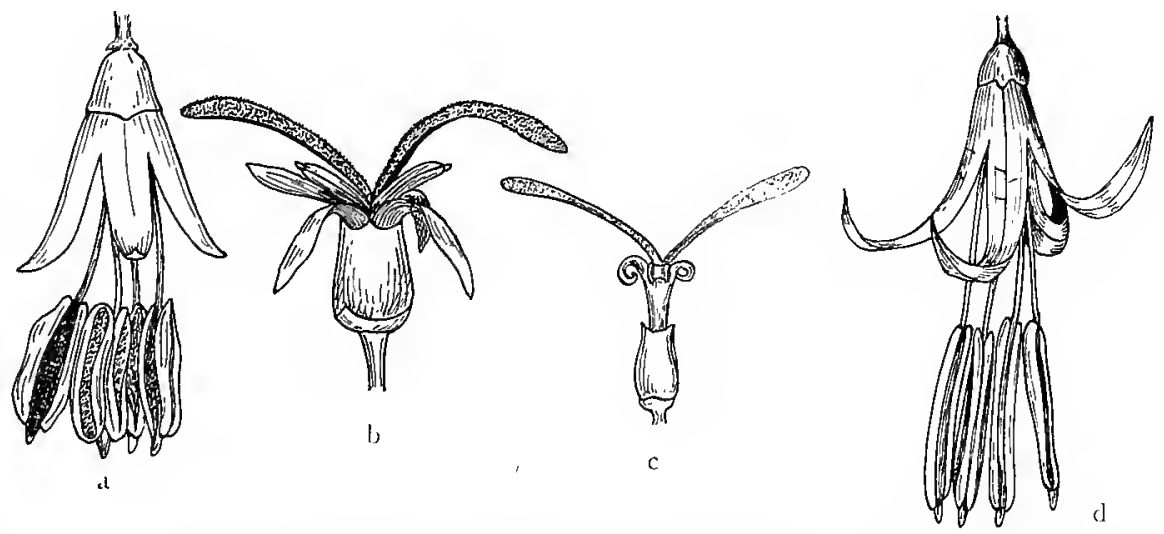

Fig. 24. a-c Coprosma triflomm, a male, b apparently bisexual, c female flower; d $C$. pyrifolium, male flower. All $\times 3$.

found in the alpine fern-beds, c. $1200 \mathrm{~m}$, not far from the Correspondencia Camp (fl. $\delta^{\pi} 5 \mathrm{I}$ I7, no. 5OI); also in some of the deep gorges, by the stream, not much above sea level, f. i. in $Q$. de las Casas (past fl. $q^{11 / 2} 17$, no. 499). Specimens from open and sunny stations (nos, 499 and 5OI) differ from others by the firmer, bright green leaves.

The removal of Psychotria pyrifolia to Coprosma is quite welcome from a geographical point of view. BERTERO 1. c. suggested that it was a mere form of his Hippotis; HoOker and ARNotT, 1. c. 360, called it Psychotriar, while Hemsley and JoHow dropped the question mark. It is dioecious and the structure of the flower is the same as in C. triflormm; accordingly, it differs widely from Psychotria. The male flower has not been described before; it is brownish green with yellow anthers. The corolla measures $8-9 \mathrm{~mm}$ and is deeply cleft with linear, acute, reflexed lobes; the stamens are inserted at the base of the corolla tube; the filaments measure $8-9$, the anthers $5-6 \mathrm{~mm}$.

C. pyrifolizm, sometimes rather like the preceding, is a much larger tree with thinner and broader, more pyriform leaves, indistinctly serrulate in the upper half and with narrower meshes in the net of venules. As was pointed 
out by JOHOW, it is also distinguished by the presence of domatia on the leaves. It also differs in the somewhat larger and more obovoid fruit as well as in the shape of the male flower, as seen from my figures.

C. pyrifolinm is related to C. laevigatum Cheesem. from Rarotonga and to other species from the same region, and probably more nearly allied to these than to its congener in Masatierra.

Area of distribution: Endemic.

\section{Galium L.}

110. G. masafueranum nov. spec. - Fig. 25 .

Perenne, sat pusillum, \pm decumbens. Radix primaria tenuis persistens, multiceps. Caules numerosi, tenuissimi, fragiles, inferne ramosi, repentes, ad

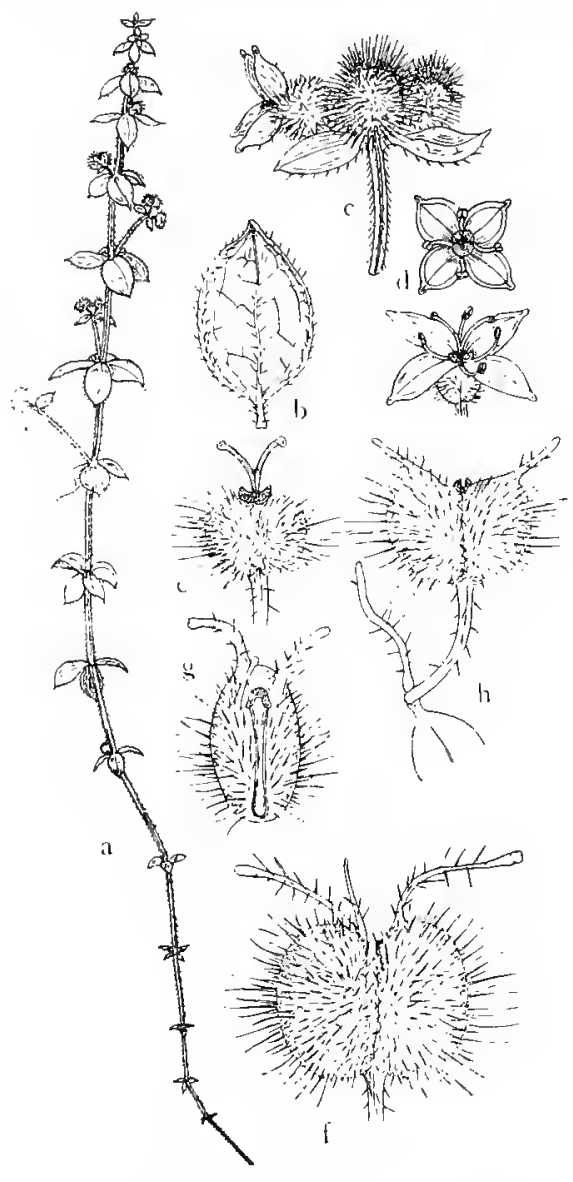

Fig. 25. Galium masafueranum: a branch, nat. size; b lower side of leaf, $\times 2 \frac{1}{2} ; c$ inflorescence and a flowers, $X$ s; e normal, unripe fruit; f ripe fruit with appendages; $g$ mericarp from ventral side with do.; h fruit with appendage on pedicel. $\mathrm{e}-\mathrm{h} \times 10$. nodos radicantes, saltem ad $2 \mathrm{dm}$ longi, manifeste 4-lineati et secus lineas dense patente-retrorse setoso-hispidi. Folia quaternaria, subsessilia vel brevissime petiolata, elliptica, plerumque manifeste mucronata sed non pungentia, secus marginem revolutum nec non in nervo mediano subtus longe setosa, ceterum pilis nonnullis inspersa vel subglabra, $4-9 \mathrm{~mm}$ longa et $2-5 \mathrm{~mm}$ lata (plerumque $6 \times 4 \mathrm{~mm}$ ), inferiora jam emarcida conspicue minora. Inflorescentiae laterales breves foliis subaequilongae - duplo longiores; pedunculus setosus, \pm curvatus, denique apice recurvus, ad I $3 \mathrm{~mm}$ longus, apice $2-4$ foliatus, plerumque $1-3$-florus, floribus brevissime pedicellatis. Calyx nullus. Corolla luteoviridis, $2,5-3 \mathrm{~mm}$ diam., lobis mucronulatis $1,2-I, 3 \mathrm{~mm}$ longis et $0,8-0,9$ latis quattuor rarissime quinque, passim setosis. Stamina $0,5 \mathrm{~mm}$ longa. Stylus fere ad basin bifidus, ad $0,6 \mathrm{~mm}$ longus. Discus viridis incrassatus. Ovarium longe hispidum. Fructus $2,5 \mathrm{~mm}$ latus et $2 \mathrm{~mm}$ altus, cum setis ad $3,5 \times 3 \mathrm{~mm}$ metiens. Mericarpia reniformia, dense setoso-hispida, setis rectis vel paulo curvatis nunquam uncinatis; superne interdum appendicibus longiusculis ( $\mathrm{ad} 2 \mathrm{~mm}$ ) apice nudis ceterum setosis instructa.

Masafuera: In the alpine region, trailing in the moss mats, probably not uncommon. Western precipice, a short 
distance north of Buque Varado, c. $1230 \mathrm{~m}$ (Al.-fr. $7 / 3 \mathrm{~s} 7$, no. $367 \mathrm{~b}$ ); fell-fields near the Correspondencia Camp, c. $1200 \mathrm{~m}$; in moss among the rocks of Las Torres, I370 m (fl.fr. 14/8 I7, no. 367); C. del Barril, I I IO m (fr. 1/3 17, no. 530); Los Inocentes, $1375 \mathrm{~m}$.

The curious appendages do not appear to have been found in any other species. Their nature is problematic. In the cases where each carpel ends in such a tail-like process -it would lie near at hand to regard them as enlarged, persistent styles, but this explanation is impossible, as they are situated outside the disc; inside this the traces of the styles will be found. In several instances as many as three were found on one carpel (fig. $25 \mathrm{~g}$ ): in two cases such an appendage was found attached to the pedicel (fig. 25 h). Finally, many plants did not have any at all.

$G$. masafueranum is related to a number of Andine species, such as $G$. fuegianum Hook fil., uncinulatum DC., canescens Kunth and andicola Krause. The latter three are larger plants with many-flowered inflorescences and with much longer hairs on the fruits and leaves; G. fuegianum has larger leaves, long pedicellate flowers and a glabrous stem, and all of them have barbed setae om the fruit.

Area of distribution: Endemic in Masafuera.

Campanulaceae.

\section{Wahlenbergia Schrad.}

In Monogr. Camp. ( 1830 ) i6o Alphonse DeCandolle described $W$. fernandeziana A. DC. Four years later Colla (Mem. Accad. Torino XXXVIII. I I8, tab. 35) described Campanula Larraini Bert. ined. Colla stated that, to judge from DECANDOLLE's diagnose, $C$. Larraini was different. The material quoted by Decandolle and collected by Mrs. Graham, Douglas and Scouler shows that his species comprised several forms, for Mrs. GRAliAM collected $W$. Grahamae Hemsl. and what I call $W$. fernandeziana s. str. and Douglas and Scouler collected $W$. Larraini. This explains why A. P. DeCandolie, Prodr. VIII. 438 referred $W$. Larraini to fernandeziana as a symonym.

The question of nomenclature becomes complicated by the fact that there are two types among BERTERo's plants, both under no. 1443. I do not know if Colla did see both, anyhow, his description and plate answer very well to one of them, and this I have retained here as $W$. Larraini. DC. Prodr., HeMSLEY and JoHow write Wahlenbergia Larraini Bert., Colla, but Colla did not admit the genus Wahlenberyia, but brought his species to Campanula.

Hemslev, Challenger Report 45 rejects Larraini, but describes the new species Grahamae, based upon a part of Mrs. Graham's material. JoHow admits one species only, $W$. femandeziana $\mathrm{A}$. DC. For some reason he compares the narrow-leaved species (niy Larraini) with $W$. Berteroi, which is a quite different thing; he declares that he found all sorts of transitions between Larraini and Grahamae. It is true that there are forms apparently intermediate between Grahamae and fernandeziana s. str., but nobody who has seen these 
species growing wild should propose to unite Larraini with Grahamae. JoHow believes that the size and shape of leaves and flowers undergo so great changes with the exterual conditions that all differences will be explained in this way. He writes p. 75: „En los terrenos húmedos i sombríos se encuentran ejemplares robustos con hojas muy anchas que convienen con la descripcion de la $W$. Grahamae Hemsl.» - but this species is at home on the steep rocky ridges and grows exposed to full sunlight; nor is it true that the typical fernandesiana grows "en los lugares ménos fértiles".

All the species are small shrubs with strong, persistent root. The in florescence is terminal, and the flowering branches die in the autumn, at least the upper, floral part, while innovations are developed from their lower leafy part or from older branches.

\section{Key to the species formerly united under W. fernandeziana.}

I. Corolla campanulate, white, with narrow contracted lobes; calyx segments narrow, entire; leaves lanceolate or linear-lanceolate, \pm acuminate.

\section{W. Larraini.}

II. Corolla \pm broad campanulate to funnel-shaped with dark purplish veins; calyx segments dentate. Leaves lanceolate-ovate.

A. Leaves glabrous or nearly so, narrower toward the base: corolla campanulate with \pm erect lobes.

W. fernandeziana.

B. Leaves pubescent, with broad base, semiamplexicaul; corolla very broad with broad, revolute lobes. W. Grahamae.

I I. W. Larraini (Bert., Colla) Skottsb. - Syn. Campanula Larraini Bert. ined., Colla 1. c.; JoHow, Estud. 75, sub $V^{\prime}$. fernandeziana. - Fig. 26 a-e.

Masatierra: Bertero ${ }^{1}$ no. 1443 ex p.! Scouler! Douglas! - On the low, dry ridges between the valleys; Pto Frances, Loma Incienso, in shrubberies, $360 \mathrm{~m} ; \mathrm{Q}$. de la Pesca de los Viejos, c. $225 \mathrm{~m}$, in a small ravine (fl. ${ }^{13} / 1216$, no. 127); C. Salsipuedes, one plant in the height of c. $75 \mathrm{~m}$, several higher up, c. $465 \mathrm{~m}$ (beg. fl. ${ }^{8 / 12}$ I6, no. 51 - f. parce pilosa); between $Q$. Juanango and La Vaquería, c. $300 \mathrm{~m}$. - A form with spread hairs on the leaves was also collected by SCOULER and DOUglas!

Suffrutex erectus plerumque glaberrimus, dense ramosus, ramis suberectis sat dense foliosis. Caulis glaber. Folia coriacea, lanceolata vel lineari-lanceolata, 20-30 $\mathrm{mm}$ longa, $4-8 \mathrm{~mm}$ lata, basi angustata, apice açuminatim producta, argute serrata, supra glabra vel secus medianum pilosa, subtus glabra vel rarius pilosiuscula. Flores contracte paniculati. Calyx glaber lobis angustissimis acutis, integris vel rarissime denticulo glandulaeforni uno vel altero munitis. Corolla \pm anguste campanulata, glabra vel secus marginem loborum pilosiuscula, alba, I4-15 $\mathrm{mm}$ longa, fauce $6 \mathrm{~mm}$ dian., expansa ad $15 \mathrm{~mm}$ lata, lobis angustis erecto-patentibus apice convolutis, $6-7 \mathrm{~mm}$ longis et basi $4 \mathrm{~mm}$

1 Bertero named the plant in honour of a certain Mr. Larrain, who seems to have communicated some species from Juan Fernandez. This gentleman is not included in the list of collectors compiled by Joнow, and I have not seen herbarium labels with his name. 
latis. Stamina $3,2-3,5 \mathrm{~mm}$ longa, filamentis triangulato-linearibus ad $1,5 \mathrm{~mm}$ longis, basi setis nonnullis instructis, antheris ad I,8 mm. Stylus $4 \mathrm{~mm}$ longus, sub apice incrassatus et parce pilosus.

Area of distribution: Endemic in Masatierra.

I I 2. W. fernandeziana (A. DC. ex p.) Skottsb. -- JoHow, Estud. 75. Plate 20, fig. 9; text fig. $26 \mathrm{i}-1$.

Masatierra: Mrs. Graham! Bertero no. 1443 ex p.! Gay! SkottsBERG I9O8 no. 4I7! - On the higher ridges in the centre of the island, or in open stations below the forest. North face of Co Damajuana, $530 \mathrm{~m}$; Co Pirámide, near Portezuelo, abundant in one place; V. Colonial, C. Central, $570 \mathrm{~m}$,
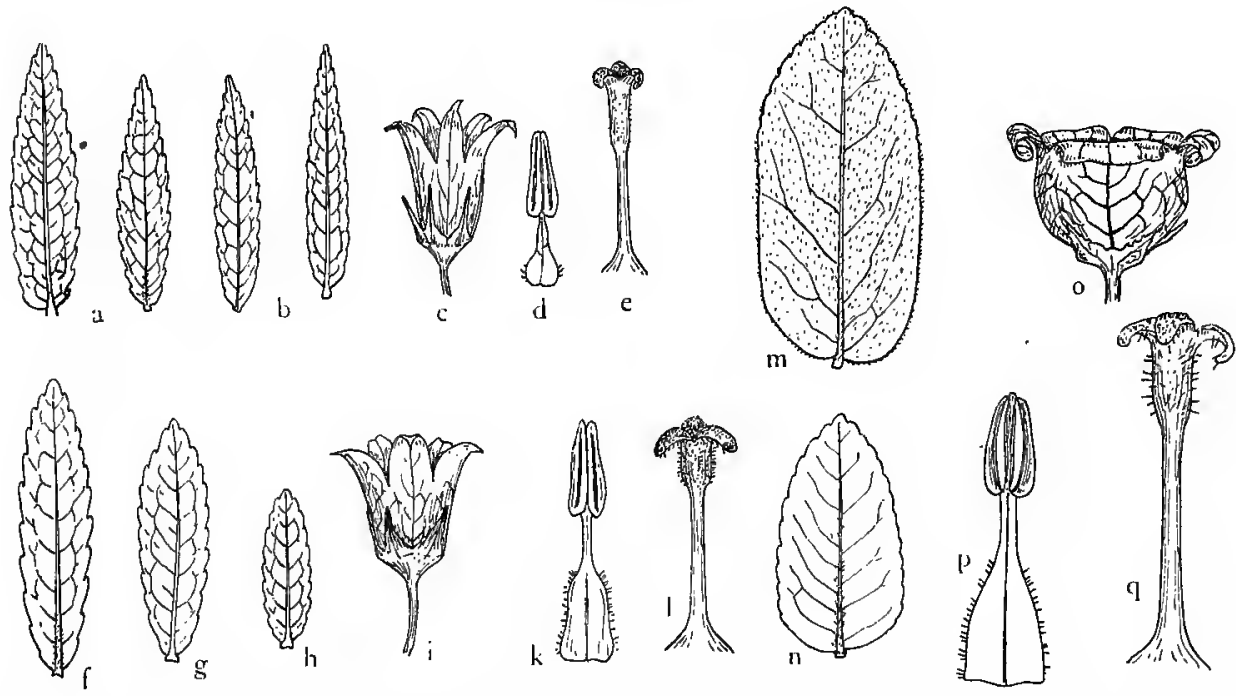

Fig. 26. a-e Wahlenbergia Larraini: a leaves (no. 51), lower and upper surface; b same of no. 127, upper and lower surface; c flower, d stanen, e pistil; a-c nat. size, d-e $\times 5$. f-1 W. fernandeziana: f leaf of no. 267 (upper surface), g no. 325 (lower surface), h 305 (do.), i flower, $\mathbf{k}$ stamen, 1 pistil; $\mathrm{f}-\mathrm{i}$ nat. size, $\mathrm{k}-\mathrm{l} \times \mathrm{s} . \mathrm{m}-\mathbf{q} W$. Grahamae: $\mathrm{m}-\mathbf{n}$ leaves, upper and lower surface, o flower, $p$ stamen, $q$ pistil; $m-0$ nat. size, $p-q \times 5$.

with the following (beg. fl. $18 / 117$, no. 305); Pta San Carlos, near the sca, rare (fl. $9 / 1$ I 7, no. 267 ); Pto Ingles, central ridge (fl. ${ }^{19 / 1} 17$, no. 325 ); ridge between Co Yunque and Villagra, c. $200 \mathrm{~m}$ (fl. $7 / \mathrm{I} 17$, no. 264). A f. elata with long, thin, less densely foliate branches and very lax inflorescence was collected near Portezuelo (fl. ${ }^{19} / 3 \mathrm{I}$, no. 1223 ).

Suffrutex erectus subglaber, ramis curvato-erectis dense foliosis, caule plerumque glabro. Folia subcoriacea, lanceolata vel lanceolato-ovata, sessilia, basi et apice sensim angustata, dense et argute serrata, reticulatim nervosa, glabra vel supra secus medianum puberula, $15-30 \mathrm{~mm}$ longa et $5-9 \mathrm{~mm}$ lata. Inflorescentia \pm laxe paniculata, floribus longe pedicellatis, pedicellis glaberrimis, bracteis foliosis ovato-triangularibus. Calyx glaber apice violaceus lobis triangulatis $5-6 \mathrm{~mm}$ longis basi $2-2,5 \mathrm{~mm}$ latis, margine parce glanduloso denticulatis. Corolla ampla campanulata, extus puberula, I5-16 mm longa, aperta I 2 - 20400. The Nat. Hist. of Juan Fernandez and Easter Isl. Vol. II. 
usque ad $20 \mathrm{~mm}$ diam., fauce $9 \mathrm{~mm}$ diam., alba, inferne pulchre purpureo. venosa, lobis $6-7 \mathrm{~mm}$ longis basi $4-4,5 \mathrm{~mm}$ latis, paulo reflexis, planis, margine puberulis. Stamina filamentis $3 \mathrm{~mm}$ longis a basi lata subiter angustatis, valde setosis; antherae $2 \mathrm{~mm}$ longae. Stylus ad 5,5 mm longus, versus apicem incrassatus nec non dense setosus, lobis stigmatiferis margine et subtus pilosis.

Area of distribution: Endemic in Masatierra.

113. W. Grahamae Hemsl. - JoHow, Estud. 75 sub fernandeziana. Plate I5, fig. I; Plate 20, fig. I0; text fig. $26 \mathrm{~m}-\mathrm{q}$.

Masatierra: Mrs. Graham! Moseley! - Mountain ridges in the centre of the island. V. Colonial, C. Central, $570 \mathrm{~m} \mathrm{(f.} 18 / 1$ I 7, no. 306); Portezuelo de Villagra, near the pass and abundant in places, 550-600 m (f. $15 / 12$ I6, no. $1226 ; f .{ }^{24} / I_{2} I 6$, no. 1224 , f. minus scabra ad praecedentem vergens; $f$. $10 / 1$ I 7 , no. 1225 , f. laxior); B. Villagra, rock wall at the back of $Q$. de la Choza, c. $400 \mathrm{~m}$.

No. 1226 is the most extreme Grahamae that I have seen. Of the bthers nos. I 224 and 1225 have smaller flowers, measuring only $20 \mathrm{~mm}$ across. The possibility of bastards occurring between this and the former should be considered.

Suffrutex effusus, vage ramosus ramis prostrato-adscendentibus longis subflexuosis, pubescenti-setosis foliosissinis. Folia chartacea, sessilia, ovato-lanceolata vel ovata, acutiuscula, basi lata fere semiamplexicaulia, dense sed interdum indistincte denticulata, utrinque pubescenti-scabra, subtus in nervis dense pilosa, $20-35 \mathrm{~mm}$ longa et $10-16 \mathrm{~mm}$ lata. Inflorescentia pseudo-unbellata, foliis triangulato ovatis instructa, haud multiflora sed ob magnitudine florum valde conspicua. Calyx glaber lobis triangulatis $5-7 \times 2-3 \mathrm{~mm}$, inferne dentatis. Corolla late campanulata vel sub fauce leviter constricta fere globoso-campanulata, extus puberula, alba, eximie purpureo-venosa, cum lobis $13-15 \mathrm{~mm}$ longa, expansa ad $25 \mathrm{~mm}$ lata, fauce $16-17 \mathrm{~mm}$ diam., lobis revolutis late triangularibus $7-8 \mathrm{~mm}$ longis et $8-10 \mathrm{~mm}$ latis, margine puberulis. Stamina filamentis $3-4 \mathrm{~mm}$ longis a basi lata valde angustatis; antherae $1,5-2 \mathrm{~mm}$ longae. Stylus $6,5-8 \mathrm{~mm}$, versus apicen incrassatus et cum pagina inferiore stignatorum setosus.

Area of distribution: Endemic in Masatierra.

I I4. W. Masafuerae (Phil.) Slkottsb. Stud. 6. - Syn. W. tuberosa Hook. fil., JoHOW, Estud. 78.

Masafuera: Germain! Guajardo! - coast cliffs from B. Toltén to Vara. dero and Lobería, rather common; also in the outer part of the canyons, on rock ledges and in crevices. Only once observed in the highlands, north of Casas, c. I 200 m. Fl.-past fl. Feb. I917, no. 428.

f. rosea: A typo differt corolla praecipue basin versus pulchre rosea. Masafuera: $Q$. de la Lobería, one large specimen found among the typical plants (fl. ${ }^{17} / 2$ I 7 , no. 489 ).

When describing Euphorbia Masafuerae (Bot. Zeit. XIV. 647) PhILIPPI felt sure of the generic position, but later he began to doubt the correctness, as shown by GUAjARDo's specimen, labelled in PHILIPPI's hand-writing: "Euphorbia? Masafuerae $\mathrm{Ph}$. (nonne potius Wahlenbergia?) Masafuera 1869 Leybold». 
In Stud. 6 I quoted this species from Masatierra also. There were two sheets of a Wahlenbergia in Herb. Lund; they had no labels, but on the sheets was written in J. G. AGARDH's hand-writing: "Juan Fernandez, D. Douglas no. 48". As D. never visited Masafuera, I concluded that they came from Masatierra. They did not belong to the species known before from Masatierra; thus, only $W$. Masafuerae remained, or a new species. Habitually they looked like the former, but differed in the closer serrature of the leaves; that were glabrous and had a somewhat different venation. The basal parts of the speciinens were missing.

Comparing these specimens a second time with the rich material of $W$. Masafuerae now at hand, I found that the differences quite forbid an identification. I further found that, apart from these specimens, nothing like them had ever been collected in Juan Fernandez, nor did such a species exist among Douglas's plants in Herb. Kew. During my visit to that herbarium last year I had a look at the Wahlenbergiae from Saint Helena, and was at once struck by the great likeness between $W$. linifolia A. DC. and the plants in Herb. Lund. Some time ago I sent for both and was able to establish their identity. The examination of a capsule of the alleged Dovglas plant revealed that it is 2 -valvous as in all the St. Helena species, while all Juan Fernandez species have. 3-valvous capsule. Certainly we can draw no other conclusion than that the statement on the Lund specimens is quite false. Aud if we go back to DougLas's journal, only lately published, we read under no. 48: „Campanula(?) leaves alternate, sessile, lanceolate, serrate, smooth above, slightly pubescent underneath» etc. Douglas no. 48 is $W$. Larraini. The person who distributed the plants in question to Lund has made a rather dangerous mistake.

Area of distribution: Endemic in Masafuera.

I15. W. Berteroi Hook. et Arn. - JoHow, Estud. 75. - Syn. Campanula gracilis var. revoluta Colla 1. c. I 19. - Plate 20, fig. 8.

Masatierra: BERTERO no. 1440 ! 》ad rupium fissuris in montibus editioribus et in Goats island». Rediscovered in Masatierra by us, but not in the whigher mountains : B. Cumberland, Pta San Carlos, two small specimens (f. $9 / 117$, no. 265); in the sand outside the caves, one large and beautiful plant (f. $7 / 1216$, no. 43). Both localities near the sea.

Santa Clara: Bertero ("Goats island"); JoHow! - Morro de los Alelíes (also observed by JoHow), fr., sone few fl. left, ${ }^{26} / 117$, no. 345 .

$W$. Berteroi has (just as $W$. Masafuerae) a large, lactiferous subterranean bulb, formed by the base of the primary stem together with the primary root. From the surface of this bulb spring the vegetative-floral shoots, each apparently of one year's duration. The shape of the corolla is unlike that in other species. Its colour is a deep rosa, the base crimson. Style and stamens are rose-coloured, anthers golden yellow. The style is much longer than in other species, the stigma visible in the mouth of the corolla. As the figure of HoOKER and ARNOTT in HoOKER's Journ. I (1834) plate 137 is incorrect as to the flower, another was prepared. The flower figured here was trimerous throughout with 6 sepals etc., an anomality sometimes observed.

Area of distribution: Endemic in Masatierra and Santa Clara. 


\section{Lobelia L.}

I16. L. anceps Thunb. - JoHow, Estud. 76. - Syn. L. rupicola Colla, Mem. Accad. Torino XXXIX (I834) I20.

Masatierra: El Pangal, wet rocks near the waterfall, 2 I5.m (A. $1 / 1$ 17, no. 22I); Pto Ingles, moist rocks near the sea (fl.-unr. fr. ${ }^{20} / 117$, no. 314 ; also found by BERTERO and by JOHOW).

Masafuera: coast rocks near $Q$. de las Casas, where water trickles down (also observed by JoHOw); in the Casas canyon, humid rock wall; in the interior of $Q$. de las Vacas (fl.past fl. $13 / 217$, no. 496); Q. del Varadero, at the waterfall in the small branch of the canyon.

A variable species that ought to be studied on material from different countries. In Juan Fernandez, the colour of the flower ranges from a deep lilac blue to almost white. REICIE, Fl. Chil. V. 87 writes splanta anual?», but the Juan Fernandez plant is perennial, as usually stated.

Area of distribution: South Africa, Australia, New Zealand, Chile from prov. Maule to Valdivia; Juan Fernandez.

\section{Compositae.}

\section{Lagenophora Forst.}

I17. L. Harioti Franch. -- Syn. L. hirsuta, SkotTsberg, Stud. 5. Fig. $27 \mathrm{f}-\mathrm{i}, 28 \mathrm{f}-\mathrm{g}$.

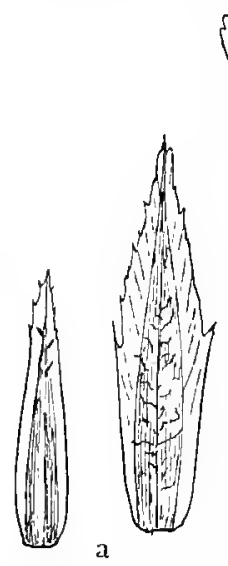

a

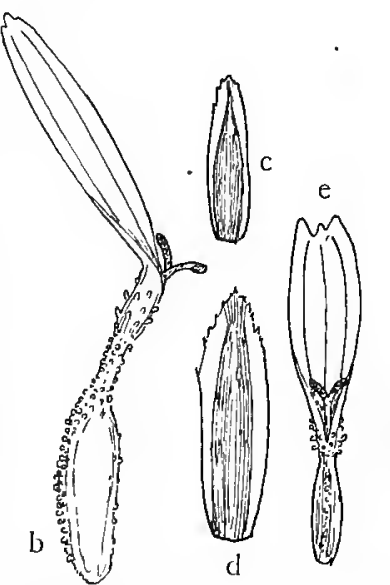

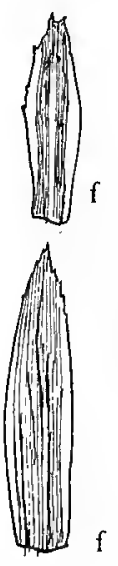
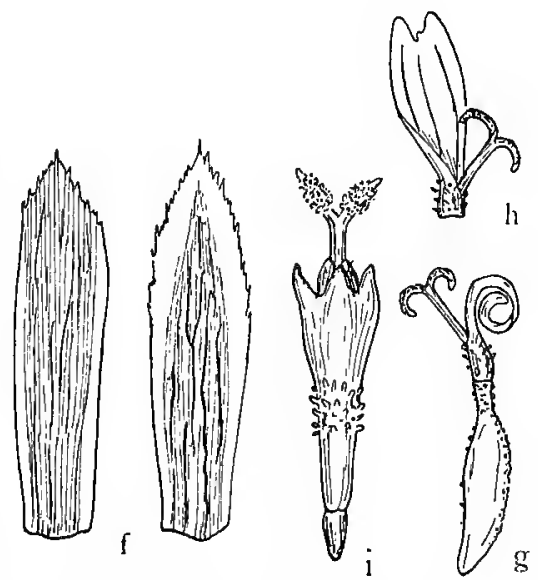

Fig. 27. a-b Lagenophora hirsuta, orig. PoEppig: a involucral scales, b ray floret. $\mathrm{c}-\mathrm{e} L$. nudicaulis from Falkland Isl, leg. SkortsBERG : c, d involucral scales, e ray floret. $\mathrm{f}-\mathrm{i} L$. Harioti from Masafuera: $f$ involucral scales, $g$ ray floret, $h$ expanded ligule, $i$ disc floret. - All $X$ s.

Masafuera: Alpine fell-fields, scarce. Highland north of Casas, from I $130 \mathrm{~m}$ to the top of Las Torres, $1370 \mathrm{~m}$ (fl.-fr. ${ }^{14} / 2$ I7, no. 484); C. del Barril, c. $830 \mathrm{~m}$, rare, $925 \mathrm{~m}$ more common (fl.fr. $1 / 3$ I 7 , no. 536); Los Inocentes, c. I $375 \mathrm{~m}$. 
The insular plant is certainly identical with $L$. Harioti Franch. Miss. sci. Cap Horn V. 344, of which I have seen type material from Herb. Mus. d'hist. nat. in Paris. Another question is if this is different from L. nudicaulis (Comm.) P. Dus. (fig. $27 \mathrm{c}-\mathrm{e}, 28 \mathrm{a}-\mathrm{b}$ ). L. Harioti (fig. $28 \mathrm{c}-\mathrm{e}$ ) is larger and more slender, the leaves less crowded, more distinctly dentate and always pubescent. The involucral scales are larger, c. $4 \mathrm{~mm}$, rarely exceeding $3 \mathrm{~mm}$ in nudicaulis. The flowers are slightly larger, but the achenes look very much the same in both. There may be as much reason to regard $L$. Harioti as a form of the other, in which case the name var. gracilis (Alboff) should be used. ALBOFF, Contr. Fl. Terre de Feu II. 27 placed his variety under L. hirsuta Less. It has
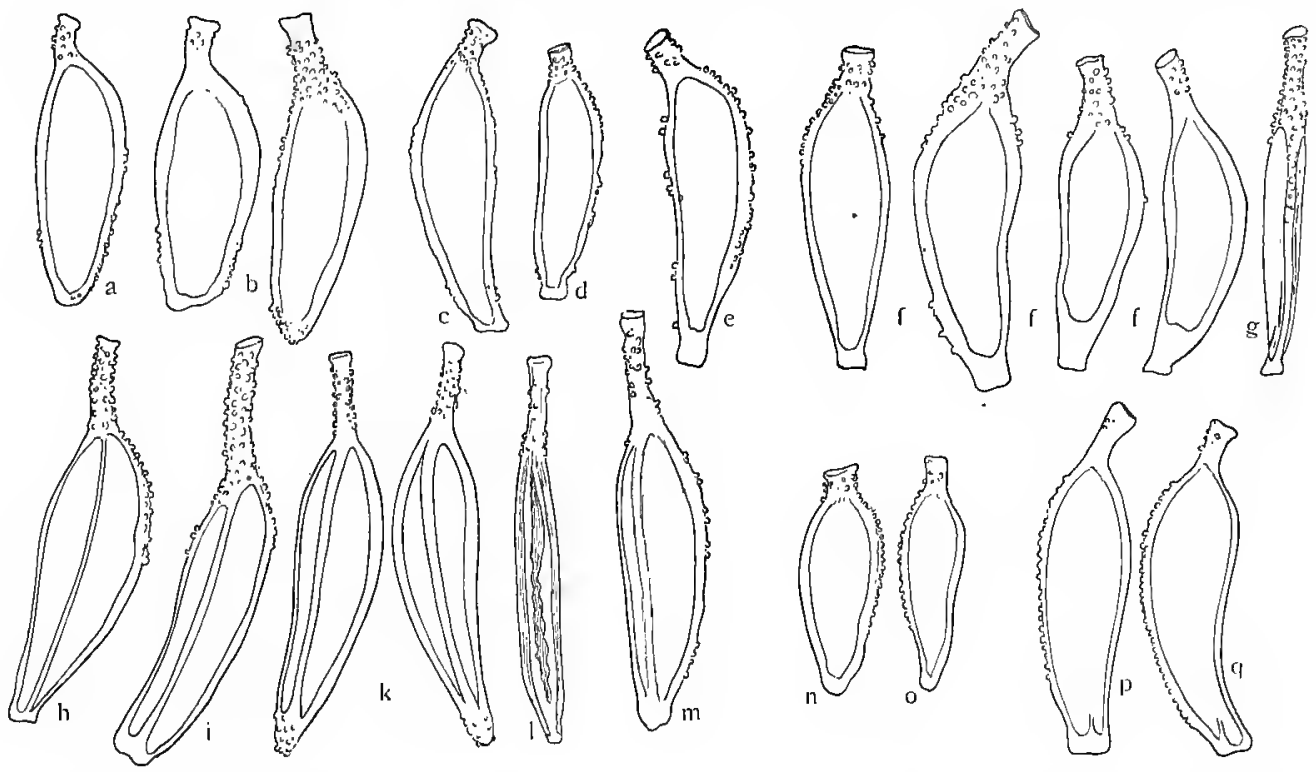

Fig. 28. Achenes of Lagenophora.' a, b L. nudicaulis, a orig. Commerson, b ex herb. LINK (Berlin). c $-\mathrm{g}$ L. Harioti: c Cord. Rio Manso leg. Reiche, d Cord. Linares le., Reiche, e Fuegia leg. Skorrsberg no. $15 \mathrm{I}$, f Masafuera, $\mathbf{g}$ Masafuera, dorsal view, $\mathbf{h}-\mathbf{m} L$. hirsuta: $\mathbf{h}$ orig. Poeppig, i Cord. Rio Manso leg. Reiche, k-1 Cord. Valdivia leg. Neger, from both sides and from the back, $m$ Cord. Nahuelbuta leg. ReIche. n-o L. pumila: n leg. Bastian, o leg. Cockayne no. 79. $\mathbf{p}-\mathbf{q}$ L. petiolata, $\mathrm{p}$ leg. Colenso, q leg. HaAst. - All $\times 16$.

nothing to do with this. L. hirsuta (fig. $27 \mathrm{a}-\mathrm{b}, 28 \mathrm{~h}-\mathrm{m}$ ) is known by the shape of the leaves, that are larger and more deeply crenate, and especially by the long beak of the achene, which also has strong lateral nerves absent in the others, as seen from fig. $28 \mathrm{~h}-\mathrm{m}$; these nerves are also visible in the figure of POEPPIG and ENDLICHER, Nov. gen. et spec. plant. II tab. 26, though not mentioned in the descriptions. I have figured one achene of the original material (fig. $28 \mathrm{~h}$ ). L. Harioti has been mistaken for hirsuta on account of the hairy leaves, also by the writer (Zur Flora des Feuerlandes, Wiss. Erg. Schwed. Suidpolar-Exp. IV: I: probably all the specimens quoted belong to L. Harioti). FrancheT regarded his species as mbien différente de $L$. Commersonii (= nudicaulis) et voisine de $L$. Forsteri (= pumila) : comp. fig. $28 \mathrm{n}-\mathrm{o}$. Still, it is much nearer to the former. L. pumila differs in the shape of the leaves and bracts and also 
in the smaller achenes with their very short beak. The achene of $L$. Harioti is more like that in L. petiolata Hook f. (fig. $28 \mathrm{p}-\mathrm{q}$ ). Both pumila and petiolata come from New Zealand. All the species in question form one small natural group.

The type material of $L$. Harioti was out of flower: ALBOFF describes these as light rose-coloured. In the plant from Masafuera the colour varies from white to rose, turning \pm crimson with age.

I have seen $L$. Harioti (determined as hirsuta or sometimes nudicaulis) from the following stations: Fuegia, Ile Clarence, Sholl Bay, HARIOT $15 / 5$ I 883 (type); Ushuaia, in pratis alpinis 11/3 IgO2, Skottsberg no. I5I; Chile, Cord. Linares, 2200 m, Jan. I 897. ReICHE; Cord. of Rio Manso, 900-I 400 m, Feb. 1896, Reiche; Cord. of Chillan, $2000 \mathrm{~m}$, Jan. I895. ReICHE.

Area of distribution: Andes of South Chile to Fuegia; Masafuera.

\section{Erigeron L.}

In the large collections of Santiago, Kew etc. I have not met with any near relatives of the island species. It is noteworthy that not one of the numerous alpine species, described from Chile by PHILIPPI, seems to be related to the new forms from the mountains of Masafuera. In order to get the opinion of a specialist, I asked Professor VIERHAPPER to examine my material and to compare my new species with the collections in the Vienna museums, what he most willingly did. He thinks, and here I quite agree with him, that all the island species, in spite of their different habit, are related to each other; E. rupicola is very unlike the rest, but the principles of its morphology are the same as in the others. Professor VIERHAPPER mentions the following species as more or less related to the insular forms: E. lepidotus Less. (Hawaii), spiculosus Hook. et Arn. (Chile), uliginosus Benth. (Columbia) and heteromorphus Rob. (Mexico). Hemsley compared $E$. fruticosus (Juan Fernandez) with E. Darrellianus Hemsl. (Bermuda). Prof. VIERHAPPER adds: "Als besonders wichtiges gemeinsames Merkmal erscheint mir die \pm tiefe Serratur der Blätter, die z. B. bei spiculosus genau so ist, bei lepidotus allerdings nicht, der aber dafür sonst dem fruticosus sehr nahe zu stehen scheint".

I I8. E. fruticosus DC. - Johow, Estud. 51; SkotrsberG, Stud. 4. Fig. 29 a-c.

Masatierra: Rocky and stony ground on the high ridges or near the sea, also in the dry western parts of the island, but not reported from the eastern section. North-east corner of El Yunque, c. $580 \mathrm{~m} ; \mathrm{V}$. Colonial, C. Central on the crest, $570 \mathrm{~m}$ (also JoHow); Cave no. 6, one specimen; Portezuelo de Villagra (also observed by JoHow), 500-600 m, not uncommon (fl. ${ }^{3} / 12 \mathrm{I} 6$, no. 9); Q. del Monte Maderugo, road-side in the macal, $240 \mathrm{~m}$, two specimens; C. Salsipuedes, c. $600 \mathrm{~m}$ (fl. ${ }^{8} / 12 \mathrm{I} 6$, no. 73); between La Vaquería and Q. Juanango, rather abundant; south slope of Co Tres Puntas; C. de las Cabras, $380 \mathrm{~m}$; $\mathrm{B}$. Chupones, among rocks in the grass (fl. $5 / 1$ 17, no. 255). 
Masafuera: Scattered on the ridges and in the canyons; Q. de las Chozas, Dicksonia-grove; $Q$. de las Casas (also observed by JoHow), rare; $Q$. Inocentes, c. $500 \mathrm{~m}$, abundant; Q. Angosta; Q. del Varadero, rare; slopes above Las Chozas, $700-750 \mathrm{~m}$, in the grass (fl. ${ }^{12} / 2,{ }^{25} / 2$, no. 524 ); C. del Barril, c. $750 \mathrm{~m}$.

f. majuscula n. f. - Fig. $29 \mathrm{~d}-$ e. - A typo differt statura majore et magnitudine omnium partium. Rami ad $70 \mathrm{~cm}$ longi et $6,5 \mathrm{~mm}$ crassi, dense foliosi. Folia ad $18 \mathrm{~cm}$ longa et $2 \mathrm{~cm}$ lata, sat profunde lacerata. Panicula amplissima. Flores $q$ ad $7 \mathrm{~mm}$ longi, tubo 3 , limbo $4 \mathrm{~mm}$. Achaenia ut in typo. Masafuera: $Q$. de las Casas, one specimen in the bottom of the gorge in a shady corner (fl. $6 / 3 \mathrm{I} 7$, no. 375). - Looks like a "gigas-form». Aster erigeroides Hook. et Arn. (= E. fruticosus) $\beta$ proliferus Comp. Bot. Mag. II. 48 is a large-leaved form, but nothing is said about the size of the heads etc.; it is described "corymbis quasi lateralibus», an expression difficult to understand.

Area of distribution: Endernic.

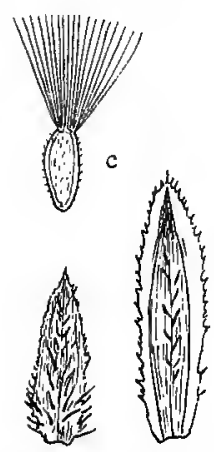

2
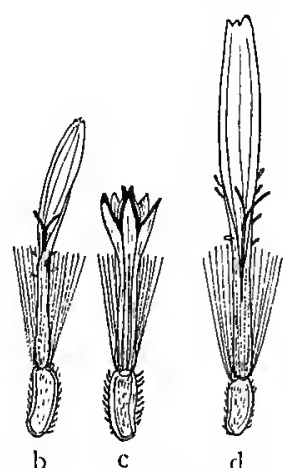
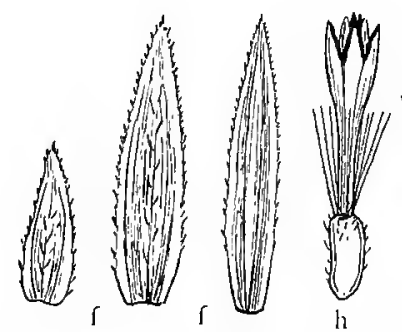
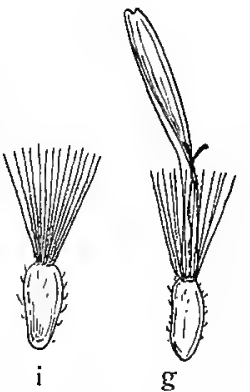

Fig. 29. a-e Erigeron fruticosus: a outer and inner scales, $\mathbf{b}$ ray and $\mathbf{c}$ disc foret; $\mathbf{d}-\mathbf{e}$ f. majuscula, ray floret and achene. $\mathrm{f}-\mathrm{i} E$. huteoviridis, $\mathrm{f}$ outer and inner scales, $\mathrm{g}-\mathrm{h}$ ray and disc floret, $\mathrm{i}$ achene. - All $\times 6$.

\section{*IIg. E. luteoviridis nov. spec. - Fig. 29 f-i.}

Euerigeron suffruticosus polycephalus subglaber luteoviridis. Radix primaria persistens lignosa longissima (ad $58 \mathrm{~cm}$ longa visa), valde ramosa, multiceps. Caulis lignosus plerumque a basi ramosus; innovationes basales internodiis inferioribus elongatis, ceteris brevissimis folia rosulatim conferta gerentibus. Rami florigeri $20-30 \mathrm{~cm}$ longi, rigidi, glabri, striati. Folia inferiora dense rosulata, anguste spathulata vel lineari-lanceolata, acuta, in petiolum semiamplexicaulem longissime attenuata, plerumque $5-8 \mathrm{~cm}$ longa et $4-6 \mathrm{~mm}$ lata, versus apicem dentibus acutis parvis incrassatis utrinque circ. 5 munita, reticulatim nervosa nervo mediano permanifesto, pallida, lutescenti-viridia, subglabra (pilis nonnullis marginalibus) vel glaberrima, valde firma quasi coriacea; folia caulina inferiora similia, superiora linearia, integra, $2-4 \mathrm{~cm}$ longa et $2-3 \mathrm{~mm}$ lata. Capitula ex axillis supremis orta, subumbellatin disposita, pauca - sat numerosa, circ. $8 \mathrm{~mm}$ diam., inferiora pedunculis elongatis $3-5 \mathrm{~cm}$ longis, bracteolatis, simplicibus vel infimis parce ramosis, glabris vel parce pilosis suffulta. Involucrum $5-5,5 \mathrm{~mm}$ altum, 4,5-5 $\mathrm{mm}$ diam., subglabrum. Squamae lanceo- 
latae, acutae, hyalino-marginatae, minute laceratae nec non parce piligerae, paucae exteriores breviores $2,5-3 \times \mathrm{I} \mathrm{mm}$, intermediae numerosae $4,5-5 \times 1,2$ $\mathrm{mm}$, intimae angustiores glaberrimae. Flores radii omnes $q$ ligulati albi glaberrimi, tubo circ. $2 \mathrm{~mm}$ longo, ligula angusta suberecta apice indistincte lobulata circ. $3 \mathrm{~mm}$ longa; flores disci $\Varangle$ corolla $3-3,5 \mathrm{~mm}$ longa lutea. Achaenia ovata compressa subglabra, $\mathrm{I}, 5 \mathrm{~mm}$ longa et $0,6-0,7 \mathrm{~mm}$ lata. Pappus circ. $2,5 \mathrm{~mm}$ longus.

Masafuera: In the alpine region; edge of western precipice, above Buque Varado, c. $1200 \mathrm{~m}$ (fl.fr. $7 / 8 \mathrm{I} 7$, no. 558); C. Atravesado, c. $1350 \mathrm{~m}(\mathrm{fl} 15 / 2 \mathrm{I} 7$, no. 500). No. 558 differs from the type (no. 500) in the broader, more coarsely serrate leaves.

Near E. fruticosus, but undoubtedly quite distinct. The light colour and the thick leaves characterize the new species; $E$. fruticosus is pure green, much more villous, and has much thinner leaves, generally also a distinct trunk, which attains the height of a few feet.

Area of distribution: Endemic in Masafuera.

*I20. E. Ingae nov. spec. - Plate I6, fig. I; text fig. $30 \mathrm{a}-\mathrm{d}$.

Euerigeron perennis basi suffruticosus hirsutus oligocephalus. Caudex sat profunde infossus lignosus di- polychotome ramosus, radicibus numerosis chordiformibus; innovationes basales longi subrosulatim foliosi. Caules florigeri ad $30 \mathrm{~cm}$ vel ultra alti, sat robusti, adscendentes-erecti, sulcato-striati, pilis longis albis pluricellularibus \pm dense villosi. Folia basalia rosulata, infima tempore floris jam emortua, spathulata, in petiolum basi dilatatum longe angustata, acuta vel obtusata et mucronata, superne grosse serrato-dentata dentibus late triangulatis mucronulatis utrinque $\mathbf{I}-3(-4)$, sat obscure viridia, undique sparse et longe villosa, $4-7 \mathrm{~cm}$ longa, $8-12 \mathrm{~km}$ lata; caulina sensim minora, spathulato-linearia, breviter petiolata, margine dente uno vel altero instructa, suprema sublinearia, $2-4 \mathrm{~cm}$ longa et $3-5 \mathrm{~mm}$ lata, integra. Caulis sub capitulo terminali leviter incrassatus. Capitula terminalia et ex axillis supremis $\mathbf{I}-\mathbf{3}$ (rarius ad 5) lateralia, pedunculis tenuibus villosis ad 9- $12 \mathrm{~cm}$ longis caulem superantibus suffulta, $16-18 \mathrm{~mm}$ diam. Involucrum $7-8 \mathrm{~mm}$ altum et $10 \mathrm{~mm}$ crassum. Squamae, exterioribus paucis brevibus exceptis, $6,5-7,5 \mathrm{~mm}$ longae et $I-I, z$ latae, lanceolatae, acutatae, margine et dorso villosae, intimae margine irregulariter hyalino-laceratae, parce pilosae-glabriusculae. Flores $q$ ad $9 \mathrm{~mm}$ longae, albae, corolla $7-8 \mathrm{~mm}$ longa, tubo perparce villoso. Flores $\Varangle 5,5 \mathrm{~mm}$ longi lutei. Achaenia valde compressa, margine incrassato setoso, in latere basi et apice pilis nonnullis inspersa, $2-2,3 \mathrm{~mm}$ longa et I $\mathrm{mm}$ lata, pappo circ. $2 \mathrm{~mm}$ longo.

Masafuera: Las Torres, on rock ledges, $1370 \mathrm{~m}$ (fl. $15 / 217$, no. 39I); Los Inocentes, c. $1350 \mathrm{~m}$ (A.-fr. ${ }^{9} / 3 \mathrm{I}$, no. 556). - Named in honour of Mrs. INGA SKOTTSBERG.

var. Innocentium nov. var. - Fig. $30 \mathrm{e}$ - h. - A typo differt foliis conspicue latioribus, basalibus spathulatis $4-7 \mathrm{~cm}$ longis et $\mathrm{I}-2 \mathrm{~cm}$ latis, late rotundato obtusis, mucronulatis, margine grosse sinuato-dentatis, caulinis ovatolanceolatis subintegris vel integris, $2-2,5 \mathrm{~cm}$ longis et $7-12 \mathrm{~mm}$ latis. Inflore- 
scentia magis contracta. Involucri squamae 5-6 mm longae; flores $q 7 \mathrm{~mm}$, ఫ $4 \mathrm{~mm}$ longi. Achaenia $\mathrm{I}, 5 \mathrm{~mm}$ solum longa, pappo aequilongo. - Masafuera: Los Inocentes, c. I400 m (fl.-fr. ${ }_{1}^{9} 3$ I7, no. 557). - Only very few specimens observed; habitually somewhat different on account of the broader leaves and also notable for the smaller flowers, but more material is required in order to decide whether it deserves the rank of a species.

Area of distribution: Endemic in Masafuera.

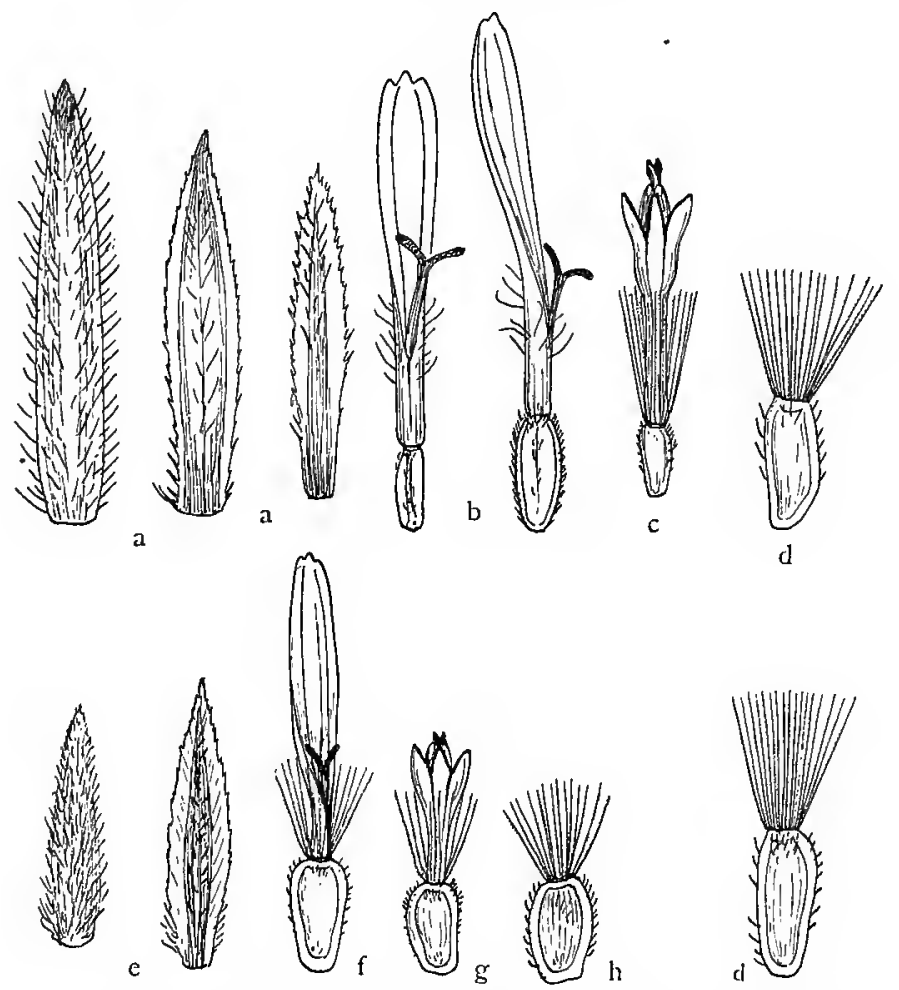

Fig. 3o. a-d Erigeron Ingae: a largest outer, and inner scales, b ray and c disc floret, $\mathrm{d}$ achenes; $\mathbf{e}-\mathrm{h}$ var. Innocentium, e outer and inner scales, $\mathrm{f}$ ray and $\mathrm{g}$ dise floret, $\mathrm{h}$ achene. All $\times 6$.

*I21. E. turricola nov. spec. - Plate I6, fig. 2; text fig. 3I a-g.

Euerigeron perennis caespitosus parvulus monocephalus. Rhizoma adscendens, radicibus numerosis fibrosis, multiceps. Folia carnosula firma, dense rosulata, spathulata, petiolo laminam aequante usque ad duplo superante, obtusatorotundata et apiculata, dentibus utrinque $I-2$ sat manifeste mucronatis ornata, $3-4 \mathrm{~cm}$ longa et $3-7 \mathrm{~mm}$ lata, saltem secus marginern pilosa vel undique hirsuta, pilis longis pluricellularibus. Scapus $5-12 \mathrm{~cm}$ altus, sulcato-angulatus, strictus vel leviter curvatus, subglaber-hirsutus, monocephalus vel rarissime ex axillo supremo capitulum alterum producens, perparce foliosus superne nudus, folia caulina $3-7$ linearia acutiuscula $\mathrm{I}-2,5 \mathrm{~cm}$ longa, summa vel interdum omnia valde reducta bracteiformia. Capitulum circ. I5 $\mathrm{mm}$ diam. Involucrum $5 \times 6 \mathrm{~mm}$. Squamae una vel altera brevis, triangulata $2,5 \times 1 \mathrm{~mm}$ solum 
metiens, ceterae $4-5 \times \mathbf{I}-\mathrm{I}, \mathrm{a} \mathrm{mm}$, lanceolatae, acutae, denticulatae, dorso dense hirsutae; intimae subglabrae, margine solum dense ciliatae nec non scariosae et denticulatae. Flores $q$ albi, circ, $9 \mathrm{~mm}$ longi, limbo angusto \pm distincte tridentato patente, $4,5-5 \mathrm{~mm}$ longo, tubo extus pilis nonnullis insperso. Flores $\Varangle$ flavi, 4,5-5 mm longi. Achaenia \pm oblique ovata, compressa, margine incrassato hirsuto ceterum subglabra vel sub apice pilis paucis bifurcatis inspersa,
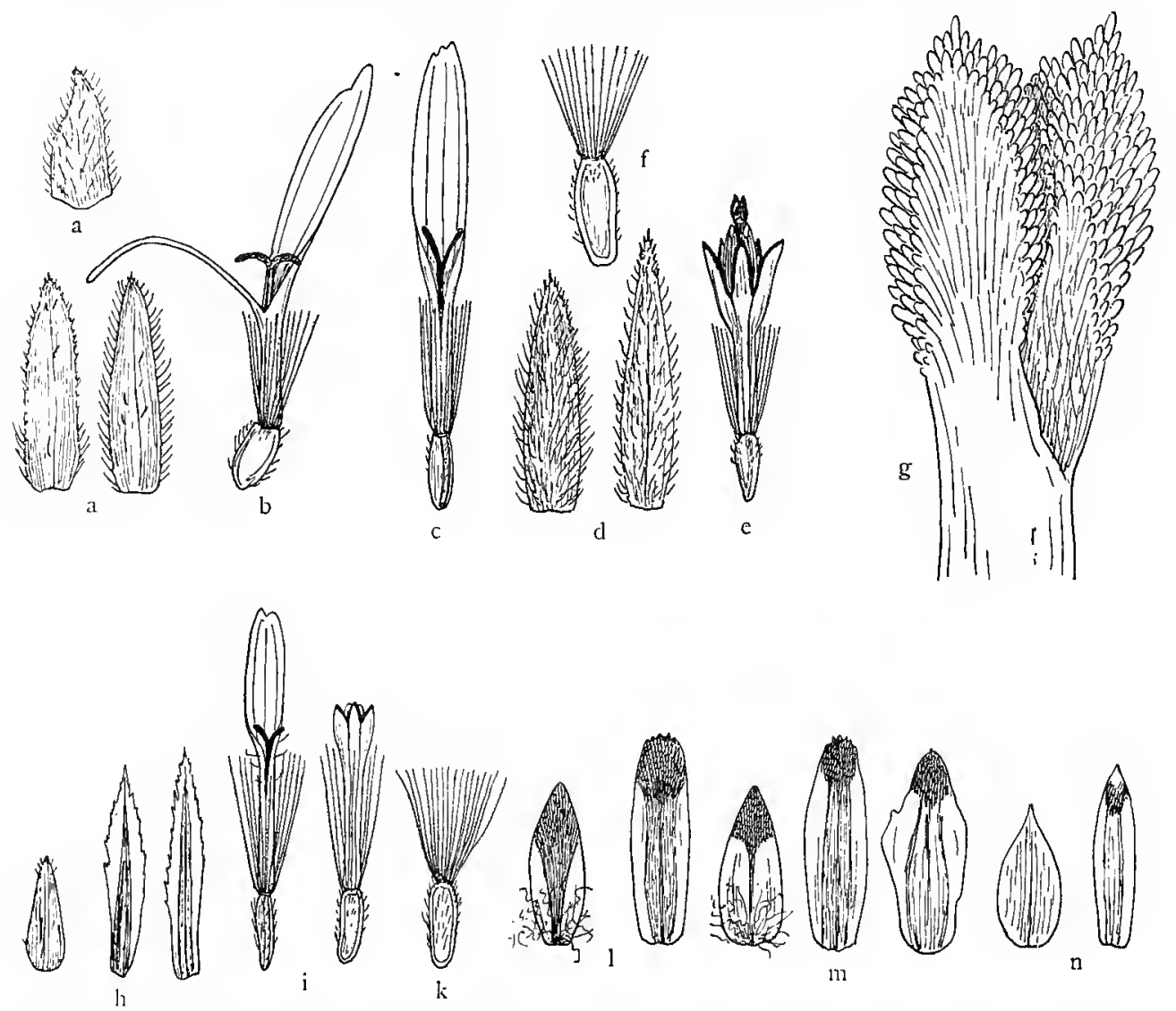

Fig. 3i. a-f Erigeron turricola: a outer and inner scales, $b$ bilabiate and $c$ normal ray floret, all from $f$. glabrior; $d$ scales from hairy specin., e disc floret, $f$ achene, $g$ lop of style. $h-k E$. rupicola: $\mathrm{h}$ one outer and two inner scales, $\mathrm{i}$ ray and disc floret, $\mathrm{k}$ achene. $1-\mathrm{m}$ Gnaphalium spiciforme, outer and inner scales, 1 of LECHLER no. I250 ex p., $m$ from Masafuera. $n$ G. spicatum no. 118 , scales. $-\mathrm{g} \times$ so, all others $\times 6$.

I,5-2 $\mathrm{mm}$ longa et $0,8 \mathrm{~mm}$ lata, pappo ad $2,5 \mathrm{~mm}$ longo. Adsunt interdum flores O bilabiati (fig. $31 \mathrm{~b}$ ).

Masafuera: alpine fell-fields near Las Torres, $1350-1370 \mathrm{~m}$ (disp. fr. $14 / 2$ I 7, no. 483 b, c; -- f. glabrior); humid moss-mats (fl. ${ }^{15} / 2$ I7, no. 483); C. del Barril, I290 m (f. glabrior); Los Inocentes, I350- I400 m.

Another characteristic species of the well. known valpine» habit. The leaves are variable as to shape and degree of pubescence, but $I$ think all the specimens collected belong to the same species.

Area of distribution: Endemic in Masafuera. 
122. E. rupicola Phil. - Johow, Estud. 51. - Fig. 31 h-k.

Masafuera: GERMAIN! without locality. - Common on the coast rocks: between $Q$. del Óvalo and $Q$. del Pasto; entrance to $Q$. del Mono (beg. $\mathrm{fl} .10 / 2$ 17, no. 417 b); between $Q$. de las Casas and $Q$. de las Vacas (beg. fl. ${ }^{10-15 / 2} 17$, no. 417); Q. Angosta, in the canyon; $Q$. del Varadero (A. $12 / 3$ I7, no. $514 \mathrm{~b}$ ); Rodado del Sándalo, abundant in places (fl. ${ }^{17} / 217$, no. 514); Q. de la Lobería, not uncommon. Seen once only in the alpine region, west of $Q$. Sanchez, I $100 \mathrm{~m}$, one specimen (fl. ${ }^{25} / 2 \mathrm{I} 7$, no. $54 \mathrm{I}$ ).

Of this peculiar plant only one small and incomplete specimen existed before, viz. the type in Herb. Santiago, so JoHow believed that it was a very rare species, while in reality it is quite common in many places on the coast cliffs. As the description of PHILIPPI is incomplete, I shall add the following notes.

The morphology is the same as in the other species without a trunk; there is a stout, woody primary root of the multiceps type; the stems are woody, profusely branched, more or less prostrate, forming dense mats. The upper part of the flowering shoots dies in the autumn, while te base persists and carries innovations. The leaves are mainly basal but seldom so densely rosulate as in the others; they are long spathulate, entire, very obtuse, fleshy and perfectly glabrous, but otherwise rather variable in outline, $3-7 \mathrm{~mm}$ broad and about 2-4 cm long, of which about one half belongs to the petiole. The upper leaves are reduced to bracts. The branches end in a terminal head; numerous lateral ones are developed in the axils of the upper leaves, borne on very long, filiform pedicels with some leaves below and bracts above; sometimes these leaves support a third generation of heads. As a rule, the pedicels are glabrous; the upper part, however, slightly pilose in no. 541. Often enough all the branches are abbreviated; if elongated, they are prostrate - ascending and rise a few $\mathrm{cm}$ only above the ground. The head measures $7 \mathrm{~mm}$ across, the involucre is $4.5 \mathrm{~mm}$ high and $5 \mathrm{~mm}$ wide, the scales $4-4.5 \mathrm{~mm}$ long, glabrous, the outer setulose near the tip, the others quite glabrous with scariose denticulate margin. The $q$ flower measures 7 , the $\Varangle 5 \mathrm{~mm}$. The achenes are typical, I,5 $\mathrm{mm}$ long, hispid along the thickened margin and on the flat surface. Pappus $2-2,5 \mathrm{~mm}$.

Area of distribution: Endemic in Masafuera.

\section{Gnaphalium L.}

123. G. spiciforme Sch. Bip. - Syn. G. spicatum Lam. var., SkotTsBERG, Stud. 5. - Fig. 3I l-m.

Masafuera: In the alpine region, apparently rare; first found by the writer in 1908. Co Correspondencia, c. $1350 \mathrm{~m}$ (past fl. -fr. $15 / 2-5 / 317$, no. 414); C. del Barril, $1290 \mathrm{~m}$.

The determination of this plant remains uncertain. Anybody familiar with the present state of confusion in the genus will understand the difficulty of classifying a species belonging to the purpureum assemblage. It is not $G$. spicatum; this wide-spread species has been introduced to Juan Fernandez and 
is easily known from the alpine Gnaphalium of Masafuera. This is strictly perennial with numerous rosulate innovations; the scape is simple or very little branched and has few leaves. The leaves are greenish grey above, snowy white with long, dense wool below, and the same kind of long, crisp wool thickly envelops the scape and heads. The latter form a dense, short almost globular spike, surrounded by leaves; sometimes there are some lateral glomerules, sessile or pedunculate. The compact globose spiles and the long crisp wool give to this form an appearance different from that of all forms of purpureum or spicatum that I have seen.

The involucral scales number 15 to 20 , all the outer are short and broad, $3 \times \mathrm{I}-\mathrm{I}, 2 \mathrm{~mm}$, acute, greenish hyaline with dark brown apex; the inner are larger, $4 \times 1-\mathrm{r}, 5 \mathrm{~mm}$, obtusely apiculate to square, denticulate, green in the centre with broad hyaline edges and a dark brown or reddish brown tip. The head measures $4 \times 2,5 \mathrm{~mm}$. In $G$. spicatum the head is smaller and narrower $(3 \times \mathrm{I}, 5-2 \mathrm{~mm})$, and not so dark, with all the scales acuminate or acute (fig. $3 \mathrm{I} \mathrm{n}$ ).

The species was brought to $G$. spiciforme after a detailed comparison with the type, LECHLER no. 1250 , of which I have seen material in Upsala, Kew and Marburg. It includes two forms, one very like my plant, another with a leafy stem, grey wool and sessile clusters of heads in all the upper axils. The latter is $=G$. mucronatum Phil. in Herb. Santiago; REICHE brought this to spiciforme, but I think it is better to regard mucronatum as distinct and to bring a part of LECHLER no. 1250 to this.

I have seen the following specimens of $G$. spiciforme, as limited above: Sandy Point, Lechler no. I250 ex p. (type), fig. 3 I 1; Port Famine, KING (s. n. G. falcatum, very like the plant from Masafuera); Orange Harbour, WiLkES (s. n. G. consanguineum); Bay San Nicolas (CunNingham). Dusến's G. spicatum from Lake Argentino in Patagonia (no. 5742) is similar in most respects. To judge from our present knowledge of $G$. spiciforme, this is a magellanic species with an outpost on Masafuera.

The sterile specimens of 1908 were compared with $G$. consanguineum Gaud. The fresh material clearly shows the difference between them, and consanguineum is brought to spicatam by most authors.

Area of distribution: South Patagonia; Fuegia; Masafuera.

\section{Abrotanella Cass.}

*24. A. crassipes nov. spec. - Fig. 32 a-h.

Pulvinatim caespitosa, caespite rotundato-subplano, denso nec non sat magno. Folia creberrime rosulata, linearia, haud marginata, curvato-patula, glabra, plerumque IO- $5 \mathrm{~mm}$ longa, infra apicem $\mathrm{I}, 5-2 \mathrm{~mm}$ lata; lamina carnosa, supra punctulis depressis inspersa, apice rotundato-subconica, minutissime apiculata, versus basin leviter angustata deinde in vaginam subhyalinam nervosam intus glandulosam dilatata. Glandulae ferrugineae stipitatae clavatae multicellulares. Scapus in ramis terminalis, I-2.foliatus, primo inter folia \pm absconditus, statu fructifero elongatus nec non incrassatus et carnosus, ad 
10-15 mm longus et $1,5-2,5 \mathrm{~mm}$ crassus, basi semper tenuis, leviter angulatus, monocephalus. Capitulum circ. $3 \mathrm{~mm}$ diam. Involucrum 6-8-phyllum squamis ovatis-latissime obovatis, obtusis, \pm truncatis, viridibus apice \pm roseo, margine hyalinis, uninerviis, basi praesertim glandulis (supra depictis) munitis, $2-2, z \mathrm{~mm}$ longis. Flores obscure rubri, pauci-sat numerosi (ad I6 visi), circ. $3 \mathrm{~mm}$ longi: ㅇ perpauci, $\Varangle$ magis numerosi, omnes fertiles, stylus floris $\not{q}$ distincte bifido fere ut in $q$. Calyx nullus. Achaenia ovoideo-fusiformia, obscure tetragona,

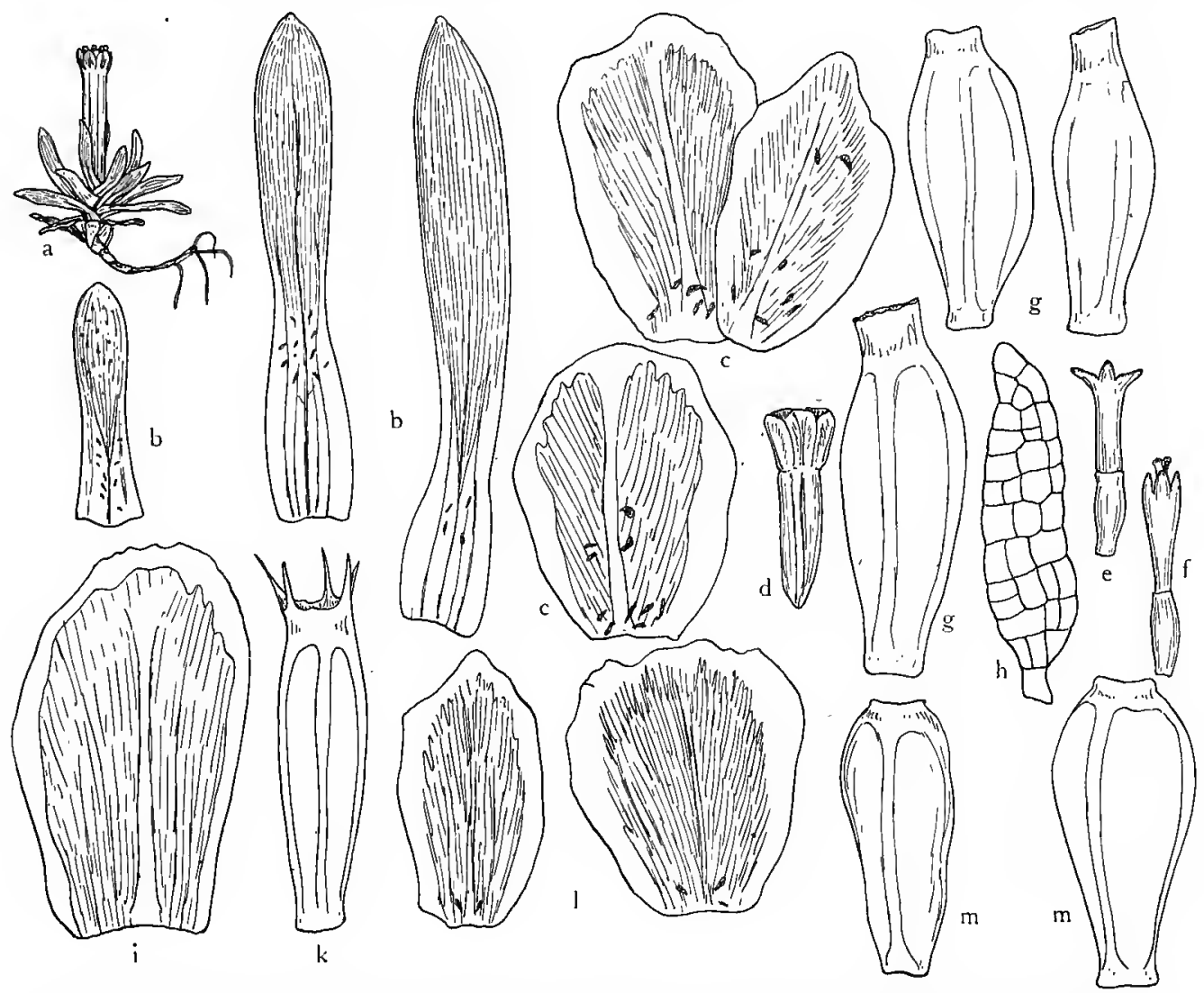

Fig. 32. Abrotanella; a-h A. crassipes: a branch, nat. size, b leaves, $\times 5$, c scales, $\times 17$, $\mathrm{d}$ scape with head, $\times 2,5$, e $\%$ and $\mathbf{f} \Varangle$ flower, $\times$ io, $\mathrm{g}$ achenes, $\times$ I7, h gland, $\times$ I50. i-k $A$ linearifolia, $\mathrm{i}$ scale and $\mathrm{k}$ achene, $\times 17.1-\mathrm{m} A$. Moseleyi, 1 scales, $\mathrm{m}$ achenes, $\times$ i 7 .

apice leviter concava et margine hunili circumvallata, glabra, $2-2,5 \mathrm{~mm}$ longa, pappo plane destituta.

Masafuera: Only found on the top of Los Inocentes, 1325-1400 m, abundant in places (past fl.fr. ${ }^{9} / \mathrm{s} 17$, no. 502).

$A$. crassipes is nearly related to $A$. linearis Berggr. (New Zealand) and to A. linearifolia A. Gray (West Patagonia, Fuegia). It differs from the former in the shape of the flowers and achenes and especially in the leaves, which have a long pilose sheath in $A$. linearis. I have not seen type material af $A$. linearifolia, but specimens from Pto Churucca in Herb. Kew are rightly named and 
agree very well with the type; only, the involucral scales are said to be "sub 2-3-nervatae» (Proc. Amer. Acad. V. I37) and I find them I-nerved (fig. 32 i). The achenes have a corona of $4-5$ long bristles (fig. $32 \mathrm{k}$ ). These bristles are present in all the achenes, while there is no trace of them in $A$.crassipes. On the other hand, the glands described above seem to be absent. The plant found by the writer in Tierra del Fuego and named linearifolia (K. Sv. Vet.Akad. Handl. LVI [19I6], 318, Taf. 23, Fig. 27) differs from the ordinary one in its much more compact growth and in the much shorter, more canaliculate leaves. Perhaps it ought to be separated from linearifolia, but the coroniform pappus is the same.

It is, however, possible that $A$. crassipes is not confined to Masafuera. In Herb. Kew I found an unnamed specimen, labelled "Otway Harbour, Gulf of Penas, Patagonia. Coll. Mr. Moseley Jan. 1876. Reed June 1876». It is very like my plant; the leaves are a trifle narrower, the scape not at all incrassate, in spite of the achenes being ripe, but some scapes in crassipes are less elongated and incrassate than the rest. The scales (fig. 32 l) have the same general outline and there are a few glands of the same kind. The achenes are more distinctly clavate, without any beak at all (fig. $32 \mathrm{~m}$ ). At present, I distinguish this as $A$. Moseleyi nov. spec. Further material is required to decide whether it is better to bring it to $A$. crassipes.

Area of distribution: Endemic in Masafuera.

\section{Robinsonia DC.}

Decandolle, Prodr. VI, established three sections: Symphyochaeta $(R$. macrocephala), Eleutherochaeta (R. Gayana and thurifera) and Eleutherolepis (R. gracilis). In several respects $R$. macrocephala differs so much from the other species that the most modern taxonomists would reserve the name Robinsonia for this species alone. According to my opinion, we loose more than we gain by splitting up an isolated genus like this, the species of which are, without the slightest doubt, genetically related to each other but lacking closer connection with all other genera. That, in many orders, apparently sinall characters must be, and have always been, used to distinguish the genera, is one thing; but to make this a rule is wrong: this mechanical and spiritless splitting-up process may, perhaps, satisfy the ambition of the authors of all these »new genera» but it has become a burden to all other botanists. Thus, I retain Robinsonia in its old sense, distinguishing two subgenera, Symphyochaeta, comprising $R$. macrocephala, and Eleutherochaeta to receive all the other species, which have free pappus setae and deciduous corolla. I propose to subdivide the latter subgenus into two sections, Symphyolepis with soldered (R. Gayana and thurifera) and Eleutherolepis with free involucral scales (R. evenia, Masafuerae, gracilis). There are some other differences between these sections. In Symphyolepis the base of the pappus forms a conspicuous coronula and the style of the $\delta$ flowers is shortly bifid with acute penicillate brauches; in Eleutherolepis the pappus setae are free almost to their very base, and the style is deeply bifid with linear-truncate branches. Of the three species 
of this section $R$. gracilis differs from the others by its small, narrow leaves and less constricted involucre with obsolete calyculus. Habitually, it is equally distant from all the other species.

Key to the genus Robinsonia.

I. Pappus of $q$ flower forming a tube, including the persistent corolla. Leaves with a very dense net of small pellucid venules between the nerves.

Subg. I. Symphyochaeta (DC.) Skottsb. $R$. macrocephala Dcne.

II. Pappus bristles free, caducous as also the corolla. Leaves with a much coarser net of veins. Subg. II. Eleutherochaeta (DC) Skottsb.

A. Involucral scales soldered. Leaves distinctly acuminate.

Sect. I. Symphyolepis Skottsb.

I. Scales cohaerent almost to their tips. Inflorescence rounded-flat. Leaves c. $12 \mathrm{~cm}$ long, with numerous lateral veins almost parallel with the midrib

$R$. Gayana Done.

2. Scales cohaerent to $2 / \mathrm{s}$. Inflorescence pyramidal. Leaves $\mathrm{c} .20 \mathrm{~cm}$ long with lateral veins forming a conspicuous net with large meshes.

B. Scales free. Leaves acute, but not distinctly acuminate.

$R$. thurifera Dcne.

Sect. 2. Eleutherolepis DC.

I. Calyculus conspicuous. Leaves $8-15 \mathrm{~cm}$ long.

a. Leaves fleshy with thick base, leaving semilunar, flat scars.

R. evenia Phil.

b. Leaves coriaceous with less thickened base, leaving linear, prominent scars. R. Masafuerae Skottsb.

2. Calyculus indistinct. Leaves about $3 \mathrm{~cm}$ long: $R$. gracilis Dcne.

125. R. macrocephala Dcne. - JoHow, Estud. 57. - Fig. 33 a-c.

Masatierra: Pto Frances, Loma Incienso (called thus after the Robinsonia), c. $360 \mathrm{~m}$, scattered specimens (past fl.fr. $13 / 12 \mathrm{I} 6$, no. $13 \mathrm{I}$, also observed by JoHow); hills between Pto Frances and Rabanal (Jоноw); Co Centinela, steep slope near the entrance to El Pangal, some few shrubs c. $300 \mathrm{~m}$ (fr. ${ }^{28} / 317$, no. 573).

The pappus of this species is quite unique, forming a closed, tough and firm tube with a wrinkled surface. The achenes, glabrous in other species, are setose in this. The calyculus consists of few, minute bradts. The involucre in the $O$ measures $1 O-I 2 \mathrm{~mm}$ in length by $8-9$ across; the head is about $15 \mathrm{~mm}$ long and $10 \mathrm{~mm}$ broad. The scales number 17 or 18 and are firmly soldered. The ray florets are 5 to 8 , but sometimes only 2 or 3 , sometimes none at all, according to JoHow. They are about $10 \mathrm{~mm}$ long; the ligule is atropurpureous, boat-shaped, $2 \times \mathrm{I} \mathrm{mm}$, not smaller than in other species in contrary to older statements. The disc florets are yellow with reddish lobes, $8-8,5 \mathrm{~mm}$ long including the ovary. When the fruit is ripe, the involucre bursts open in a quite irregular fashion. The achenes are much larger than in other species, $7-8 \mathrm{~mm}$. 
Unfortunately, the flowers of the few male plants seen were all gone already on the I $3^{\text {th }}$ of December, so they remain unknown. There were only few female heads still in flower and even these fairly advanced. DECAlSNE, Ann. sc. nat. I. 28 writes: „Vidi specim. unicum in herb. Mus. Paris, a Claudio Gay relatum. Floret Januario. Fructum perfecit Februario». GAY visited Masatierra in February (JoHow l. c. 38). His specimens are in fruit, and I do not think they flowered in January, as every specimen seen by us must have flowered already in November. According to JoHOw, only GAY and himself ever collected this species, but in DC. Prodr. VI. 448 we find the following statement: »leg. cl. Larrain et Claud. Gat»; comp. above, foot-note on p. I76.

Area of distribution: Endemic in Masatierra.

126. R. Gayana Dcne. - Johow, Estud. 58; Skotrsberg, Stud. Taf. 5 , Fig. I. - Fig. $33 \mathrm{~h}-\mathrm{k}, 35 \mathrm{~d}-\mathrm{e}$.

Masatierra: Common on all the ridges from Pto Frances to Co Chumacera; abundant in the higher parts where it forms a conspicuous feature in the vegetation of the rocky crests; occasionally found at lower altitudes $(280 \mathrm{~m}$ on the north, 190 on the south side of the island). - Fl. Dec. 1916, nos. 22 and $1232 \delta, 23,84$ and 137 o; fr. April I9I7, no. 23 b.

Male plant: Heads less numerous than in,$+ 8-9 \mathrm{~mm}$ high, with fully expanded rays up to $12 \mathrm{~mm}$ across (larger than the female, contrary to the statement of JoHOw); involucre $5-6 \times 4,5-5 \mathrm{~mm}$; flowers yellow, ray florets generally $8,6-7 \mathrm{~mm}$ long, ligules almost plane, $3,5-4 \times 2-2,5 \mathrm{~mm}$, style slightly bifid with short triangulate, acute lobes; disc florets $6-7 \mathrm{~mm}$ long, lobes of style incrassate, conical, abruptly narrowed with apiculate tips.

Female plant: Heads as many as 100 in the corymb, $5-6 \mathrm{~mm}$ high by $4,5-5$ across; involucre $4-4,5 \mathrm{~mm}$ in length and width; flowers greenish yellow, $7-8$ ray florets $5 \mathrm{~mm}$ long, ligule \pm erect, boat-shaped, \pm bifid; disc florets $4 \mathrm{~mm}$ long not counting the exserted style, which is thick with small lobes. Achenes $2-2,5 \mathrm{~mm}$ long, those of the ray florets shorter and more curved. Both sexes with very few and small calycular bracts.

Area of distribution: Endemic in Masatierra.

I27. R. thurifera Dcne. - Johow, Estud. 59. - Fig. 33 d-g, 35 a, f, g.

Masatierra: Bertero! Söhrens! - On the ridges, among shrubs and small trees, rare. C. Chifladores, one specimen $350 \mathrm{~m}$, numerous about $450 \mathrm{~m}$ (past f. ${ }^{17} / 4$ I7, no. 619 9,620 б). Portezuelo de Villagra (also observed by SÖHRENS), south-west slope of Co Pirámide, 575-600 m, about 20 trees seen (f. ${ }^{31} / 1$ I 7 , no. 358 \&, 367 ठ): one plant epiphytic on Blechnum cycadifolium.

DECAISNE's description refers to the female plant only, and the specimen brought by SöHrens is also female. Apparently the male plant is described below for the first time.

Heads less numerous than in $q$, where there are several hundred in one panicle, $7 \mathrm{~mm}$ high, Io $\mathrm{mm}$ across; involucre $4,5-5$ by $3,5-4 \mathrm{~mm}$, cylindriccampanulate, of about 13 scales, united to above the middle, glabrous with rather abrupt, penicillate apex. Ray florets generally 5 (sometimes 6), $7 \mathrm{~mm}$ long, ligule dirty yellow, $4 \times 2 \mathrm{~mm}$, tridentate, a little fleshy; style long exserted, 
lobes ovate with penicillate apex. Disc florets $5 \mathrm{~mm}$ long, not counting the exserted stamens, yellowish green; stamens distinctly thickened below the anther, style a little exserted with orbicular-triangulate, slightly divergent stigmas, their tips penicillate. Pappus composed of very few bristles.

The following notes complete the earlier short descriptions of the female plant. Head $4 \mathrm{~mm}$ high and 4,5 across, involucre only $3 \times 3 \mathrm{~mm}$, smaller than in all the other species, with few inconspicuous calycular bracts. Ray florets generally 8 , sometimes as few as 5 , yellowish green, only $3-3,2 \mathrm{~mm}$ long with a small $(r, 5 \times 0,7 \mathrm{~mm})$, boat.shaped ligule; style thick with short lobes, yellowish green; disc florets of the same colour, $3 \mathrm{~mm}$ long, not counting the exserted style; stigmas short, divergent. Achenes 10-costate acc. to DECAISNE, 5-10 costate acc. to JoHow; I found them 5-8-costate, ribs little prominent and not equidistant. The achene is crowned by a narrow ring much less conspicuous than in $R$. Gayana. On most of the achenes examined there are one or more thick, white stripes, which proved to be composed of the resin exuded on the stem of this and other Robinsonias, but not met with on the achene in any other species. These clumps of resin were observed by DECAISNE, 1. c. 24: »le R. thurifera a ses fruits munis de côtes très saillantes et formées par une substance médullaire blanchâtre». The marginal achenes are shorter $(1,5 \mathrm{~mm}$ long) and more curved than those of the centre, where they are $2 \mathrm{~mm}$ long, a difference also noted in $R$. Gayana. There are only 5 to 10 bristles, while, in all the congeners, they are much more numerous.

Area of distribution: Endemic in Masatierra.

128. R. evenia Phil. - JoHow, Estud. 6́o. - Fig. 33 l-o, 34 b, 35 b.

Masatierra: Germain! ReEd! Downton! Moseley!, all without locality. - Not uncommon in the eastern and central parts, along the higher ridges, at the limit of the forest among brushwood, or in the humid, Dicksonia-rich woods. - C. Chifladores, one large, apparently not epiphytic specimen at $350 \mathrm{~m}$, many in the forest $500 \mathrm{~m}$, all epiphytic; between $Q$. de la Piedra Agujereada and Q. Laura, c. $500 \mathrm{~m}$, on Dicksonia, abundant; C. Centinela, $560 \mathrm{~m}$, on Dicksonia, abundant; the depression between Co Damajuana and Co Yunque, $580 \mathrm{~m}$, on Thyrsopteris; V. Colonial, C. Central, $570 \mathrm{~m}$, on Dicksonia; Portezuelo de Villagra, among shrubs c. $600 \mathrm{~m}$, several trees, all growing on tree-ferns (fl. $\delta$ $3 / 216$, no. 25); C. Salsipuedes, in Dicksonia-grove, $670 \mathrm{~m}$, seedlings (no. 74) and adult plants, all epiphytic (fl. ${ }^{13} / 1 \mathrm{~J} 7$, no. 82 $\uparrow, 83 \delta^{\pi}$ ); dense forest on a mountan spur west of Co Yunque, c. $500 \mathrm{~m}$, epiphytic; Q. Villagra, c. $500 \mathrm{~m}$, on Dicksonia.

Curiously enough it is nowhere stated that $R$. evenia is an epiphyte. It grows on the trunks of tree-ferns; only in one single case a large and old specimen was found growing on the ground, but I am inclined to believe that also this had germinated on the base of a fern tree, sending, as it often does, roots into the soil, and that the original substratum had disappeared. The seedling has fleshy, densly pilose, coarsely serrate leaves. Even the old, perfectly glabrous leaves are much more fleshy than in other species, a circumstance perhaps connected with the epiphytic life; they are as much as $1 \mathrm{~mm}$ thick (not counting the midrib), and the veins are hardly visible.

\footnotetext{
I3 - 20100. The Nat. Hist. of Juan Fernandez and Easter Isl. Vol. II.
} 

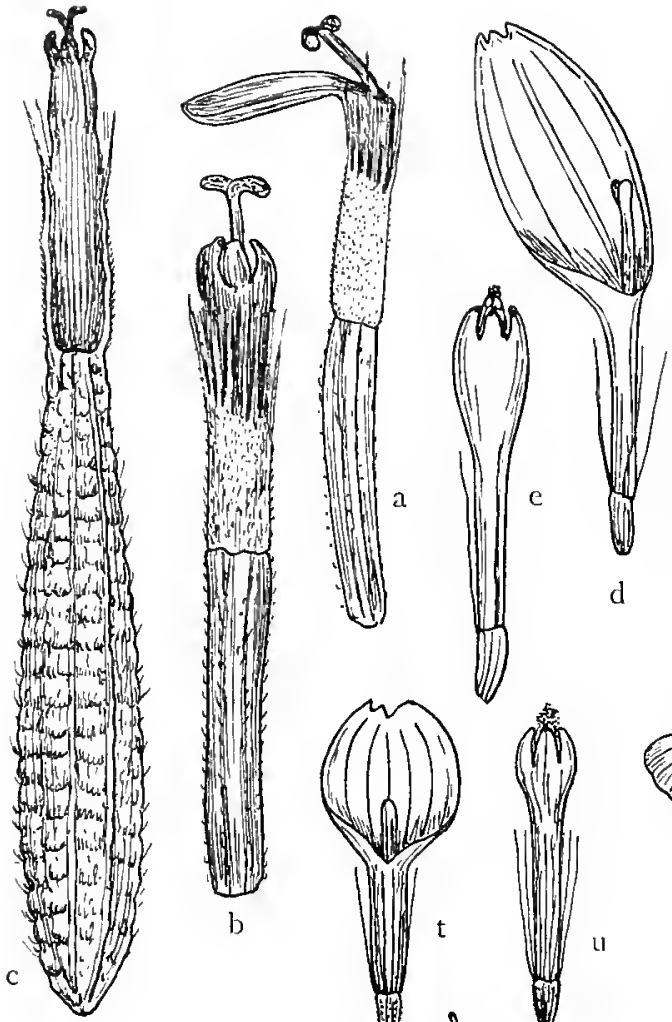

解
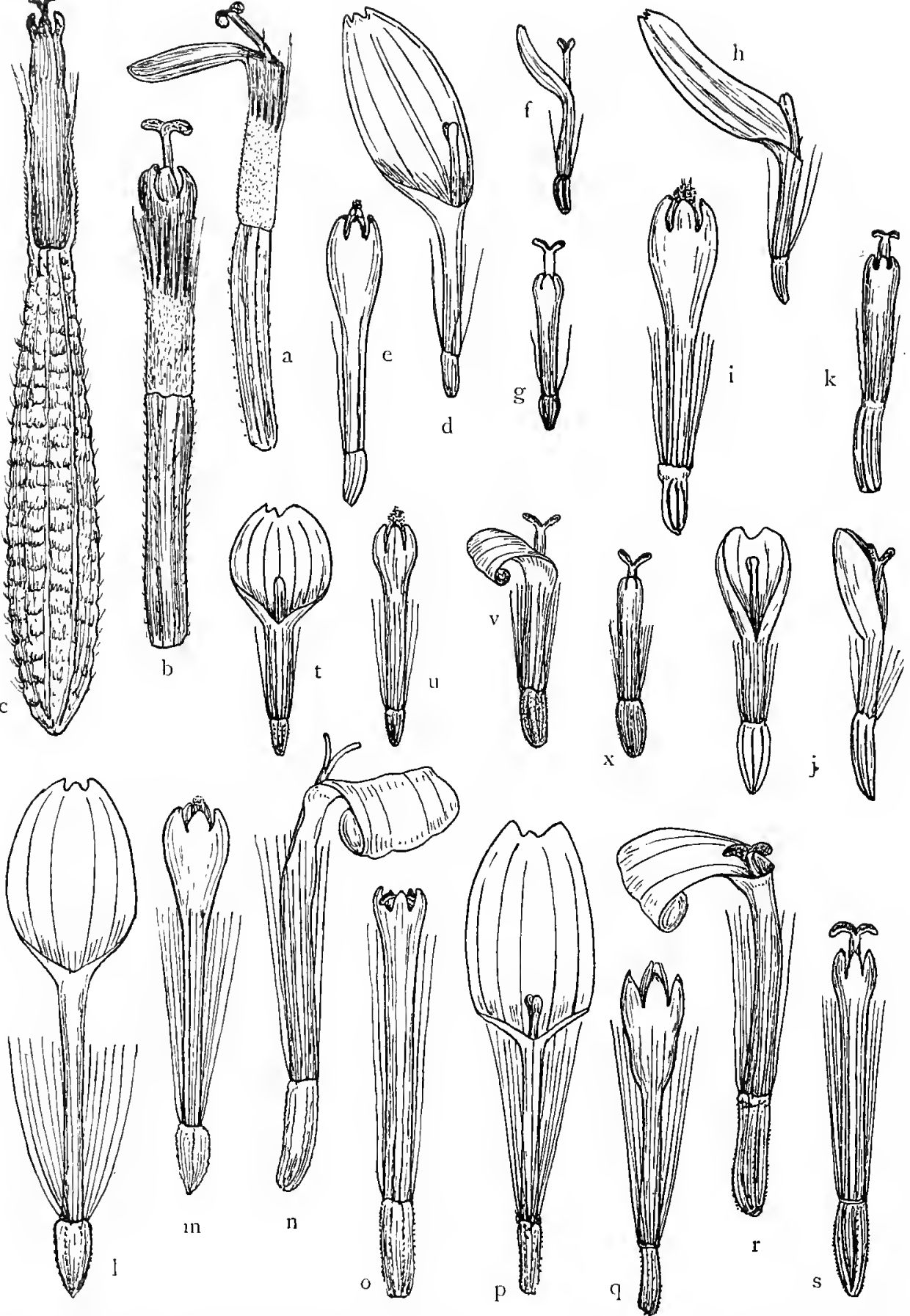

Fig. 33. Flowers of Robinsonia. a-c $R$. macrocephala $q$ : a ray, b disc floret, $\mathrm{c}$ achene. $\mathrm{d}-\mathrm{g} R$, thutifera: d ray, e disc floret of $0^{7}, \mathrm{f}$ ray, $\mathrm{g}$ disc floret of $\mathrm{P} . \mathrm{h}-\mathrm{k} R$. Gayana: $\mathrm{h}$ ray

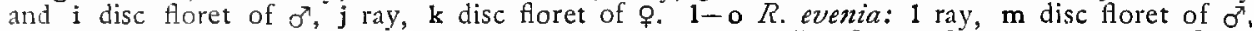
$n$ rav, o disc floret of 0 . $p-s$. Masafuerae: $p$ rav, $q$ disc floret of $\sigma^{a}, \mathbf{r}$ ray, $s$ disc floret of o. $\mathrm{t}-\mathrm{x} R$. gracilis: $\mathrm{t}$ ray, $\mathrm{u}$ disc floret of $\sigma^{x}, \mathrm{v}$ ray, $\mathrm{x}$ disc floret of $q$. - All $\times 8$. 
Male plant: Head $8 \mathrm{~mm}$ high, 10-12, rarely as much as $15 \mathrm{~mm}$ across. Involucre of about I 3 scales, $6-7 \times 4-4,5 \mathrm{~mm}$, campanulate, with 5 or 6 small calycular bracts. Ray florets 8 , pure yellow, 8-10 mm long; ligule tridentate, $3,2-4 \times 2,5 \mathrm{~mm}$; style hardly exserted, bifid; pappus rays numerous $(25-30)$ in all kinds of flowers. Disc florets greenish yellow, $6-7 \mathrm{~mm}$ long; style deeply bifid with truncate branches.

Female plant: Head about $10 \mathrm{~mm}$ high, $7-8$ across; involucre cylindrical, $7-8 \times 5 \mathrm{~mm}$; ray florets 8 , yellow, 7-8 mm long; ligule $2,5 \times 2 \mathrm{~mm}$; style greenish, deeply bifid; disc florets $6 \mathrm{~mm}$ long, yellow with greenish, barely exserted style. Young achenes slightly costate with pilose costae.

Area of distribution: Endemic in Masatierra.

*I29. R. Masafuerae nov. spec. - Plate 17, fig i; text fig. $33 \mathrm{p}-5$, $34 \mathrm{a}, 35 \mathrm{c}, \mathrm{k}$, i.

Arbuscula dioeca ad $2 \mathrm{~m}$ alta, trunco primario certe ad $7 \mathrm{~cm}$ crasso, pseudodichotome-subumbellatim ramosa, ramis junioribus viridibus, cicatricibus linearibus foliorum manifeste notatis. Folia ad apicem ramorum more generis conferta, crassiuscula, subcoriacea, dilute viridia, glaberrima, lanceolata-anguste obovato-lanceolata, in apicem acutum sensim angustata, versus basin valde contracta, margine in parte dimidia superiore minute denticulata, nervo mediano utrinque conspicuo, basi latissimo, secundariis indistinctis, angulo acuto exeuntibus, plerumque $7-12 \mathrm{~cm}$ longa et $1,5-2 \mathrm{~cm}$ lata, sed magnitudo summopere variabilis (folia ad $18, a \times 4,7 \mathrm{~cm}$ visa, in specimine sylvicola unico invento ad $22 \times 3,5 \mathrm{~cm}$ ). Inflorescentia terminalis valde ramosa corymbosa, bracteis sat parvis instructa; pedicelli capitulorum $1-2 \mathrm{~cm}$ longi, superne pilosi. Capitula $\delta$ $7 \mathrm{~mm}$ alta et Io $\mathrm{mm}$ crassa; involucrum campanulatum, $5 \mathrm{~mm}$ altum et $4 \mathrm{~mm}$ latum, addito calyculo a bracteis perpaucis angustis ad $2 \mathrm{~mm}$ longis formato. Squamae circ. 12, $5 \mathrm{~mm}$ longae et $\mathrm{I}, 5 \mathrm{~mm}$ latae, glabrae vel dorso pilis nonnullis inspersae, apice penicillatae, crassae, margine scariosae, liberae sed manifeste imbricatae. Flores ligulati 8, flavi, $8 \mathrm{~mm}$ longi, ligula $3-3,5 \times 2 \mathrm{~mm}$, irregulariter tridentata, in tubum abrupte angustata, stylo breviter bifido paulo exserto. Flores

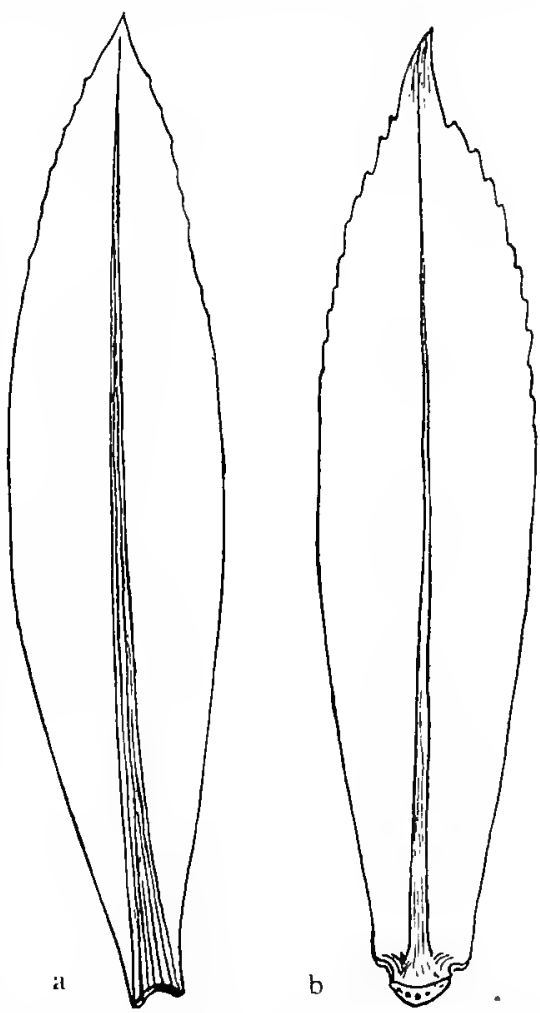

Fig. 34. Leaves of a Robinsonia Masa fuerae, b $R$. evenia. Nat. size. disci $6 \mathrm{~mm}$ longi, viridi-lutei, antheris flavis; stylus inclusus apice bifidus ramis truncatis penicillatis. Pappus multiradiatus. Capitula $q$ magis numerosa certe ad $75,8 \mathrm{~mm}$ alta et $7 \mathrm{~mm}$ lata; involucrum cylindrico-campanulatum, sub apice constrictum, basi truncatum et pilosiusculum, $6-7 \mathrm{~mm}$ altum basi $4-5 \mathrm{~mm}$ 
latum, calyculo conspicuo e bracteis 5-6 (vel ultra) ad $4 \mathrm{~mm}$ longis formato. Squamae ad I4, ut in $\delta$, scd magis adpressae et conspicue longiores. Flores ligulati 8 , flavi, $8 \mathrm{~mm}$ longi, ligula $2,2-2,5 \mathrm{~mm}$ longa et $\mathrm{I}, 5-2 \mathrm{~mm}$ lata, subtridentata; stylus exsertus ramis patentibus. Flores disci viridescentes, $6 \mathrm{~mm}$ longi, staminodiis minutis, stylo exserto ut in praecedente. Achaenia fusiformia, fusca, 9-IO-costata, c. 2,2 mm longa; pappus setis circ. 25 basi annulum minutum formantibus.

Masafuera: On the high ridges, generally growing in the fernbeds, often much damaged by the goats, which had killed a great many specimens. Edge of western precipice, above Buque Varado, c. $1250 \mathrm{~m}$; near the Correspondencia camp, I $130 \mathrm{~m}$ (fl.-past fl. ${ }^{15}{ }_{i 2}$ I 7 , no. 434 q, no. I $233 \delta^{j}$ ); Las Torres, I $370 \mathrm{~m}$, rare; C. Atravesado, I $350 \mathrm{~m}$, one small tree; C. del Barril, c. $750 \mathrm{~m}$; Los Inocentes, $740-950 \mathrm{~m}$, among Dicksonia, also seen growing on the trunk of this; slopes of $Q$. Varadero, c. $650 \mathrm{~m}$. One aberrant sterile plant was observed in $Q$. de las Chozas in dense forest, with long, thin leaves (no. 374); one seedling was found in the Casas canyon.

Of special interest as the first Robinsonia reported from Masafuera. It is very near $R$. evenia, but as a rule not epiphytic and differing in many respects. The leaves (fig. 34) have a broader midrib and are more narrowed towards the base, the base is less incrassate and the scars left linear, not triangular or semilunar as in caenia. The female head is a trifle smaller and has a more conspicuous calyculus. The details of the flowers show some differences, as seen from my illustrations.

Area of distribution: Endemic in Masafuera.

I30. R. gracilis Dcne. - Johow, Estud. 6I. - Fig. $33 \mathrm{t}-\mathrm{x}, 35 \mathrm{~h}$.

Masatierra: In the shrubberies of the ridges, not seen at a lower altitude than $530 \mathrm{~m}$, scarce. Between Q. de la Piedra Agujereada and Q. Laura, robust specimens; C. Centinela (also observed by JoHOw), $530 \mathrm{~m}$, forming small thickets and exceptionally well developed (fr. ${ }^{28} / 3$ 17, no. 577); crest of the island above Pangal, c. $800 \mathrm{~m}$, very scarce; V. Colonial, C. Central, c. $570 \mathrm{~m}$, solitary; Portezuelo de Villagra, one 07 plant near the SELKIRK memorial (buds $3 / 12$, beg. fl. $\left.{ }^{14} / 1_{2} 16,110.24\right)$, and a few $q$ plants, one of which grew on Blechnum cycadifolium (fl. ${ }^{25} / 12$ I6, no. I95), C. Salsipuedes, $730-750 \mathrm{~m}$, solitary (beg. fl. $8 / 12$ 16, no. 78 ơ, 81 우).

Jоноw writes 1. c. "lígulas numerosas i mucho mas largas que en las demás especies: . Hemsley's figure of a male plant shows 8-10 ligules (pl. 55). My observations, made on abunclant living material, are not in accordance with JoHow's statements.

Inflorescence comparatively small, only containing $20-25$ heads. Calyculus of few, minute bracts. Involucre $4 \mathrm{~mm}$ high and $4 \mathrm{~nm}$ across, little exceeded by the florets, of about 12 scales, firmly pressed together in $q$, much less so in $\delta$. The male head is $7-8 \mathrm{~mm}$ across, the ray florets generally 8 , bright yellow, $5 \mathrm{~mm}$ long; ligules $2,5 \times 2 \mathrm{~mm}, 2-3$-dentate. Style slightly bifid with erect branches. Disc florets yellow, $4 \mathrm{~mm}$ long, style deeply bifid with truncate branches, hardly reaching the full length of the stamens. 
The female head is $4 \mathrm{~mm}$ across; ray fiorets 8 , yellow, $4 \mathrm{~mm}$ long with small ligule (c. I $\times 0,9 \mathrm{~mm}$ ), 2-3-dentate. Disc florets cylindric, yellowish green, 3,a mm long, with exserted bifid-truncate style and minute staminodes. The achenes are 1,2 mm long, costate, glabrous according to JoHow, but minutely scabrid.

A rea of distribution: Endemic in Masatierra.
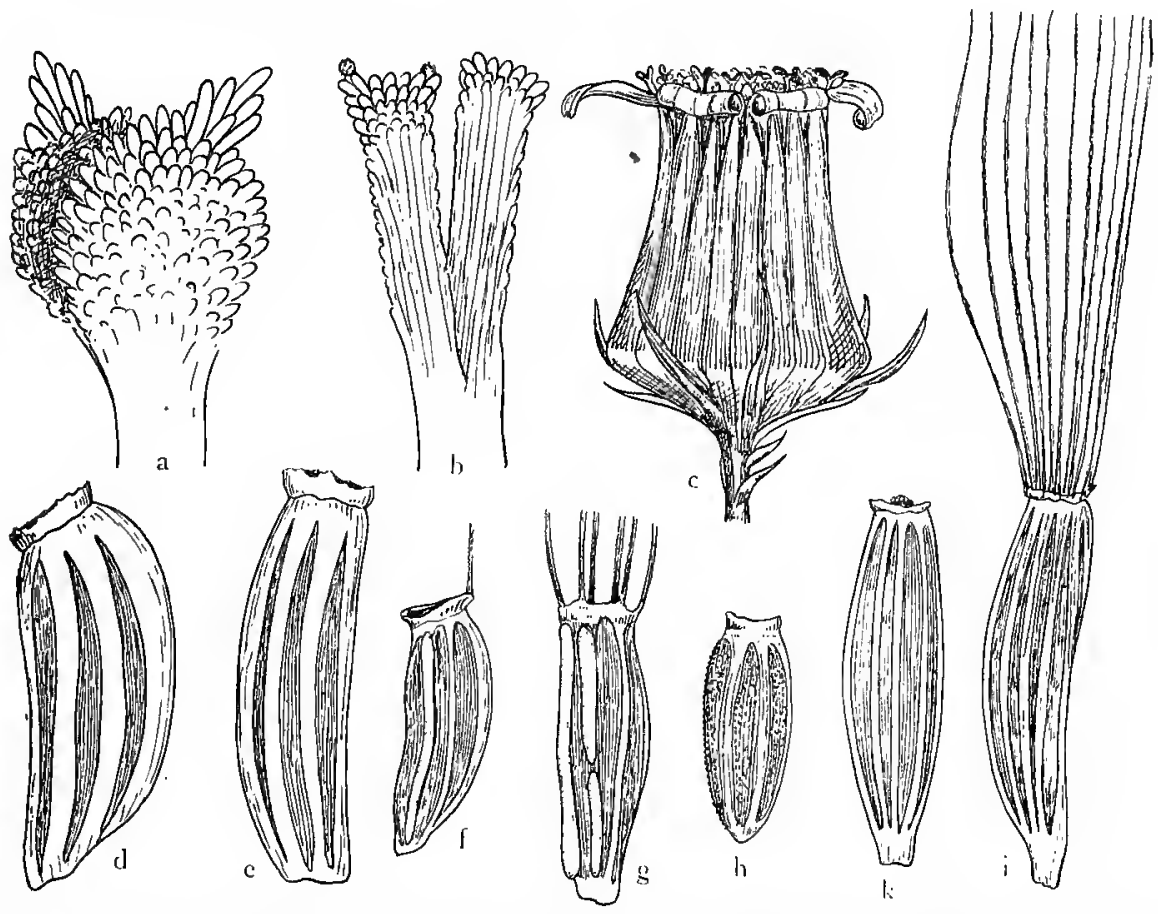

Fig 35. a-b tip of style in male disc florets, a of $R$. thurifera, b of $R$. evenia, $\times 50 . \mathrm{c}$ o head of $R$. Masafuerae, $\times 5 . \quad \mathbf{d}-\mathbf{i}$ aclienes: $\mathbf{d}-\mathrm{e} R$. Gayana, ray (d) and disc (e); $\mathbf{f}-\mathbf{g} R$. thur $i$ fera, ray (f) and disc ( $\mathrm{g}$ ); $\mathrm{h} R$. gracilis (disc); $\mathrm{k}-\mathrm{i} R$. Masafuerce, disc (k) and ray (i). $\mathrm{i}-\mathrm{i} \times 17$.

\section{- Rhetinodendron Meisn.}

I31. R. Berterii (Dcne) Hemsl. - Johow, Estud. 55. - Fig. 36.

Masatierra: in the high parts of the central section, generally in open, low forest, rarely observed below $500 \mathrm{~m}$, scarce. - El Rabanal (JoHOw); the depression between Co Damajuana and Co Yunque, $540 \mathrm{~m} ; \mathrm{V}$. Colonial, C. Central (also observed by JoHOW), on both sides of the crest, 535-570 m, many specimens (past fl. $q 18 / 117$, no. 301); Portezuelo de Villagra, a few trees on a rock ledge, c. $600 \mathrm{~m}$ (beg. fl. ${ }^{14} / 12$ 16, no. I34 ${ }^{\lambda}$, I35 q); Q. Seca, in the forest, one seedling; C. Salsipuedes (also observed by JOHOW); highest part of $Q$. Salsipuedes, rare (f. $\delta^{2} \% / 12$ I6, no. 173) ridge west of Co Yunque, c. $530 \mathrm{~m}$; Q. Villagra, in the forest c. $500 \mathrm{~m}$, solitary (also observed by JOHOW); south slope of Co Chumacera (fl. $q 6 / 1$ I7, no. 253).

According to JoHOw, Rhetinodendron generally is an epiphyte, and later 
authors have repeated this statement, adding their own reflections. I shall return to this question when dealing with my ecological observations: at present it suffices to tell that, in spite of the very special attention paid to this plant, of which I have seen much more than earlier visitors, I havc been unable to discover a single case where an adult specimen was epiphytic. Once, two seedlings were observed on Thyrsopteris, but seedlings of Robinsonias as well as of Dendroseris micrantha are often found growing on the trunks of arboreous ferns.

The structure of the head in Rhetinodendron is interesting and will be described with full details later; this time I only refer to my figures. The pap-
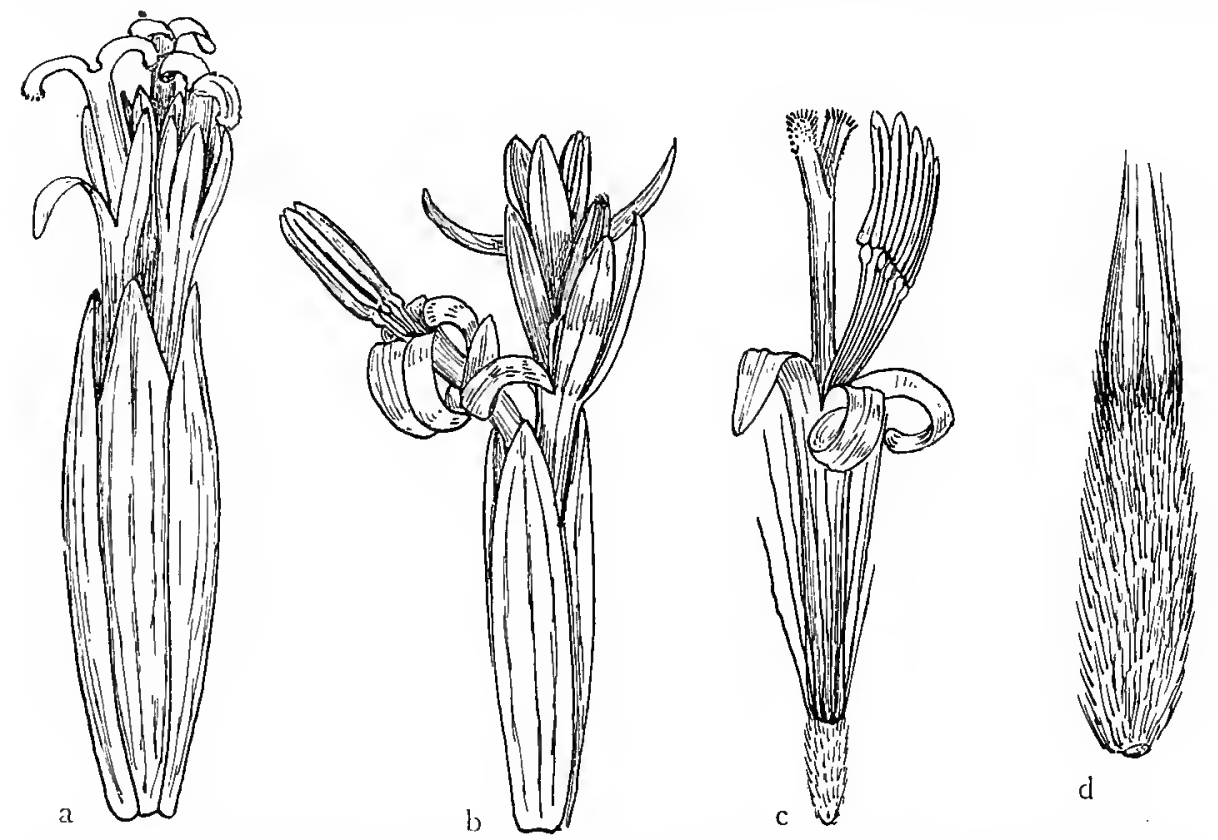

Fig. 36. Rhetinodendron berterii: a o head, b or head, c or flower, d achene - All $\times 8$.

pus is peculiar, for it forms four different portions, two larger lateral and two smaller, dorsal and ventral; the achene is flattened in tangential direction.

Area of distribution: Endemic in Masatierra; monotypic.

\section{Centaurodendron Johow.}

I32. C. dracaenoides Joh., Estud. 63; Skotrsberg, Stud. 5, Taf. 5, Fig. $2-3$.

Masatierra: only on the high ridges encircling Cumberland Bay, very rare. Forest on the very steep slope of Co Damajuana, one specimen seen; Portezuelo de Villagra, three specimens near the path just below the pass, c. $550 \mathrm{~m}$, three more seen on the slope of Co Pirámide close to the pass, $580 \mathrm{~m}$ (no. 1234); northwest face of the same nountain, on rock ledges, several trees. 
The first who collected Centaurodendron was not JoHow, but BERTERO; still, B. did not discover it. Under the name of Dendroseris micrantha, BERTEKo no. 1602 ! (Herb. Kew) there is one sheet with pieces of an old inflorcscence of the latter together with a leaf of Centaurodendron.

JoHow discovered this in July, 1892, and found it again in June, 1895 ; to judge from a specimen in his herbarium it was also gathered by SöHRENS, probably in April, I895, on the same occasion when S. found Robinsonia thurifera, for it lies together with this under the same name. I rediscovered it in August, 1908, and found the old inflorescence, just as JoHow did, but there was no trace of new ones. From this I concluded that it flowers late in the summer or even in the autumn, and I expected to get flowers this time, but was cruelly deceived. For all I could do was to state that in certain years not a single specimen produces flowers, and that the year 1916-17 was one of them.

Area of distribution: Endemic in Masatierra; monotypic.

\section{Dendroseris D. Don.}

The type of the genus is D. macrophylla D. Don, Phil. Mag. XI (1832) 388, collected in Masafuera by CUMING (Herb. Kew!). One year later DECAISNE, in Arch. de Bot. I (1833) 513, described the genus Rea Bert. ms., with the following species: $R$. macrantha Bert. et Dcne (Masatierra), Berteriana Dcne (Masatierra), pinnata Bert. et Dcne (Masatierra), neriifolia Dcne (Masatierra), micrantha Bert. et Dcne (Masatierra), marginata Bert. et Dcne (Masatierra: Portezuelo), mollis Bert. et Dcne (Masatierra: Portezuelo). In Comp. Bot. Mag. I. 32 HoOKER and ARNOTT reduced Rea to Dendroseris, listing the following species: D. macrophylla (with $\mathrm{R}$. macrantha as syn.), Berteriana, pinnata, neriifolia, micrantha, marginata and mollis.

JoHow, Estud., reduced these seven species to four, declaring $D$. Ber teriana identical with pinnata and marginata with macrophylla and rejecting $D$. mollis altogether. Of this, only the leaves, described as ssubincano-velutina» - glabrous in all the others - are known. There is no specimen in Kew, nor in Paris, and I have not been able to discover the type. JoHow guessed that a stout specimen of Gnaphalium citrinum (= cheiranthifolium) or some other similar plant was mistaken for Dendroseris. This is hardly probable. In the locality given, Portezuelo, nothing like it is found, unless a young Robinsonia or Rhetinodendron was mistaken for a Dendroseris. With regard to BERTERO's ability as an observer, this is difficult to believe.

The treatment of Dendroseris in JoHow's flora is not quite satisfactory; still, he is not to blame. He had no opportunity to see BER'lERo's types, his own material was scarce; further, when HoOKER and ARNOTT reduced Rea macrantha to $D$. macrophylla they indicated the wrong course later followed by GAY and JoHOW. HEMSLEY pointed out the validity of $D$. marginata, but JoHow brought this to macrophylla. He was equally critical against his own discoveries, for the peculiar micrantha from the coast rocks was only with hesitation classified even as a variety, v. pricinata. In the case of D. Berteriana, 
JOHOw based his opinion on BERTERO himself, who was inclined to regard it as a noticeable form of pinnata. While I regard pruinata as a species, I follow JoHow with respect to Berteriana. Finally, JoHow added one new species, $D$. gigantea, which has remained very little known until now.

Returning to D. macrophylla, it is evident that Rea macrantha is different from this. Both have incised leaves, but their shape is not the same and there are many differences in the flower and fruit. D. macrophylla is endemic in Masafuera, macrantha in Masatierra. Rea marginata is certainly distinct from both, not only in the leaves, which are entire, but also in flower and fruit, described here for the first time. Finally, var. marginata of JoHOW, at home on the coast rocks, is distinct from the true marginata and will receive the new name $D$. litoralis. Thus, $D$. macrophylla in JoHow's sense includes four species, one from Masafuera, two confined to Masatierra and one to a rock off Masatierra and to Santa Clara.

These four species differ from the rest in many respects. The stem is branched, hollow with numerous diaphragms, the receptacle is also hollow, its surface plane, with numerous fibrils round the points of insertion of the achenes. The head is very large, the flowers bright orange, the achenes distinctly winged, the pappus formed by short, irregular, \pm rufous bristles. I am pretty sure that the »splitting-up school» would reserve the name Dendroseris for these four species. My reasons for not doing so were explained under Robinsonia. The remaining species have creamy white flowers and unvinged, obovoid, slightly compressed achenes; here the accordance between them ends, and they belong to two rather different types. In $D$. pinizata and D. regia (nov, spec.) the stem is simple, but otherwise as in $D$. macrophylla; the receptacle (unknown in $D$. regia) is hollow, but concave and only slightly fibrillose. The remaining species (D. micrantha, pritnata, neriifolia and gigantea) have a branched and solid stem, and a solid, concave and naked receptacle. D. pinnata and regia are intermediate between the macrophylla-type and the micrantha-type. Either, we should retain Dendroseris in the old sense, or three genera must be recognized. Further, D. gigantea differs from all its congeners in the shape of the corolla. In view of these circumstances I propose to subdivide the genus in the following manner.

I. Stem branched, hollow. Head $3-5 \mathrm{~cm}$ wide; receptacle fibrillose; flowers orange yellow; achenes winged......... Subgen. I. Eudendroseris Skottsb. A. Leaves chartaceous, grossly dentate-lobate.

1. Leaves oblong-ovate, \pm regularly lobate. Anthers dark. Achenes mostly broader than long. Cotyledons entire.

D. macrantha (Bert. et Dcne) Skottsb.

2. Leaves often as broad as long, irregularly lobate-serrate. Anthers yellow. Achenes twice as long as broad. Cotyledons trilobate.

D. macrophylla D. Don.

B. Leaves coriaceous, entire.

1. Anthers dark. Achenes thick.

D. marginata (Bert. et Dcne) Hook. et Arn.

2. Anthers yellow. Achenes very flat. $D$. litoralis Skottsb. 
II. Head smaller. Flowers whitish. Achenes not winged.

A. Sten simple, hollow. Receptacle fibrillose. Leaves pinnate.

Subgen. II. Phoenicoseris Skottsb.

I. Pinnae deeply bifurcate with linear segments.

D. pinnata (Bert. et Dene) Hook. et Arn.

2. Pinnae \pm ovate, dentate.

a. Petiole winged, but not auriculate.

b. Petiole auriculate. D........ D. regia Skottsb.

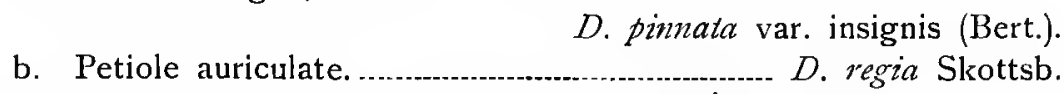

B. Stem branched, solid. Receptacle naked. Leaves entire.

Subgen. III. Rea (Bert. ex p.) Skottsb.

I. Leaf-margin minutely denticulate or entire. Ligule 5-dentate.

Sect. I. Eurea Skottsb.

a. Leaves petiolate. Involucre funnel-shaped, c. $5 \mathrm{~mm}$ high.

+ . Leaves coriaceous, narrow lanceolate.

D. nerizfolia (Dcne) Hook. et Arn.

++ Leaves chartaceous, ovate-lanceolate.

D. micrantha (Bert. et Dcne) Hook. et Arn.

b. Leaves sessile. Involucre campanulate, c. 1o $\mathrm{mm}$ high.

D. pruinata (Joh.) Skottsb.

2. Leaves densely dentate-serrate, very thin. Ligules deeply 5 -cleft.

Sect. 2. Schizoglossum Skottsb. D. gigantea Joh.

Bentiam and Hooker Fil., Gen. plant. II. 219, describe the achene of the Dendroseriidae in the following terms: "Achaenia a dorso compressa subtrigona v. 2-3-alata $\downarrow$. This description fits the genus Fitchia, a genus not very near Dendroseris. The achene of Thamnoseris is unknown. The marginal achenes of Dendroseris are more or less compressed from the back, triangular in section, with two lateral and sometimes also with a ventral wing in $E u-$ dendroseris. But all the other achaenia in the head are compressed from the sides, and their wings in Eudendroseris are dorsal and ventral only. This dimorphism clearly stands in relation with the different position in the head. It is illustrated below, fig. 37 .

I33. D. macrophylla D. Don. - JoHow, Estud. 70 p. p. min. - Fig. $37 \mathrm{a}, \mathrm{m}$.

Masafuera: Cuming! Downton! - On the walls of the canyons, also higher up on the ridges and on the top of the lofty coast cliffs in some places, scattered. Ravines above $Q$. Sanchez, solitary specimens; $Q$. de las Casas, rock ledges ( $6 .{ }^{23} / 2$ I7, no. 362 ; also observed by JOHOW); Q. de las Vacas (also JoHOW); Q. Inocentes, some large trees on the cliffs c. $500 \mathrm{~m} ; \mathrm{Q}$. Angosta, in the narrow gorge; Rodado del Sándalo, on the top of the cliff; $Q$. de la Lobería, some fine trees, c. $250 \mathrm{~m}$.

There is a good illustration of this species in Curtis, Bot. Mag. t. 6353. The specimens growing in the fissures on the canyon walls are small and seldom more than 2 or $3 \mathrm{~m}$ high; in more suitable places there are much larger ones, at least 5 or $6 \mathrm{~m}$ high and with a trunk 15 or perhaps $20 \mathrm{~cm}$ thick, so 
that D. macrophylla surpasses all the other species of Eudendroseris in size and beauty. It differs from these in several respects. The leaves are thinner, papyraceous when dry, pure dark green. Their shape is variable. The large rosulate leaves measure about $30-35 \times 26-28 \mathrm{~cm}$; they are broad ovate with cordate base, \pm acuminate, grossly and irregularly dentate with triangular, callose teeth. The petiole attains a length of $20 \mathrm{~cm}$; it is canaliculate, winged, but comparatively slender. Other rosette leaves are orbicular in outline or even broader than long ( $18 \mathrm{~cm}$ long and $23 \mathrm{~cm}$ broad in one of my specimens), cordate, deeply inciso-lobate, at least in their lower half, with linear-triangular segments. The inflorescence is composed of few but very large heads on long pedicels; the lower supporting leaves are petiolate, subpinnate or sinuate, the uppermost sessile, entire, auriculate. The corolla is c. $45 \mathrm{~mm}$ long, the ligule $3,5 \mathrm{~mm}$ across. The anthers are yellow. The style is yellow, with $3 \mathrm{~mm}$ long branches. The achenes (only few mature ones seen) are $5-6 \mathrm{~mm}$ long, brown, striate, the base narrow. In the marginal ones only the ventral wing is distinct, the lateral wings being poorly developed. Embryo with very short radicle and trilobate cotyledons.

Area of distribution: Endemic in Masafuera.

134. D. macrantha (Bert. et Dcne) Skottsb. - JoHow, Estud. 70 sub D. macrophylla. - Fig. $37 \mathrm{~b}-\mathrm{d}, \mathrm{n}$.

Masatierra: Bertero no. I60o! - Portezuelo de Villagra, on the southwest side of the pass (also observed by JOHOw), c. $580 \mathrm{~m}$, two small specimens seen (beg. fl. ${ }^{31} / 1$ I 7 , no. 330).

Bertero describes this as a tree 8 to $\mathrm{I} 5$ feet high and found in the shady woods of the high mountains. His specimens probably came from Portezuelo, as they bear no. 1600 , for no. $1601, D$. marginata, is collected in this locality. To judge from BERTERo's words, it seems he saw $D$. macrantha in more than one locality. In spite of a diligent search, we only found the two dwarf trees mentioned above, growing almost concealed among dense shrubs of Pernettya, etc.

D. macrantha differs from macrophylla in many respects. The leaves are oblong, about twice as long as broad (large blades $25-30 \mathrm{~cm}$ long by $13-14$ wide), firmer than in the latter, shorter petiolate $(6-7 \mathrm{~cm})$, narrow cordate at base but hardly decurrent, coarsely and regularly dentate-lobate; upper leaves decurrent on the petiole, subentire or entire, uppermost sessile, auriculate. Heads more numerous than in macrophylla. Flowers numerous, corollas as in D. macrophylla, 35-40 $\mathrm{mm}$ long; anthers lilac brown; connective tip yellow with numerous low, dark papillae, not found in other species. Style darker than in macropliylla. Achenes quite different, broader than long $(3,5-4$ by $4,5-6$ $\mathrm{mm}$ ), obscurely wrinkled, with narrow but distinct wings. Embryo $3-3,5 \mathrm{~mm}$ long; cotyledons entire, broader than long.

Area of distribution: Endemic in Masatierra.

135. D. marginata (Bert. et Dcne) Hook. et Arn. - JoHow, Estud. 70 sub D. macrophylla; var. marginata Joh. ex REICHE, Flora de Chile V. 5. Plate I8; Plate 20, fig. I 1 ; text fig. $37 \mathrm{e}-\mathrm{i}, \mathrm{o}$. 
Masatierra: Portezuelo de Villagra (Bertero no. I6OI!), on the northeast precipice of Co Pirámide, rock ledge, c. $625 \mathrm{~m}$ (fl.-fr. $3 / 12$ I6, no. 3). Most likely the plants observed on the face of Co Damajuana, c. $530 \mathrm{~m}$, and at the back of $Q$. de la Choza, c. $450 \mathrm{~m}$, in both places quite out of reach, belonged to this species.

JoHow wanted to explain D. marginata as a local form of macrophylla, due to external conditions. Both, however, grow in the same place and do not

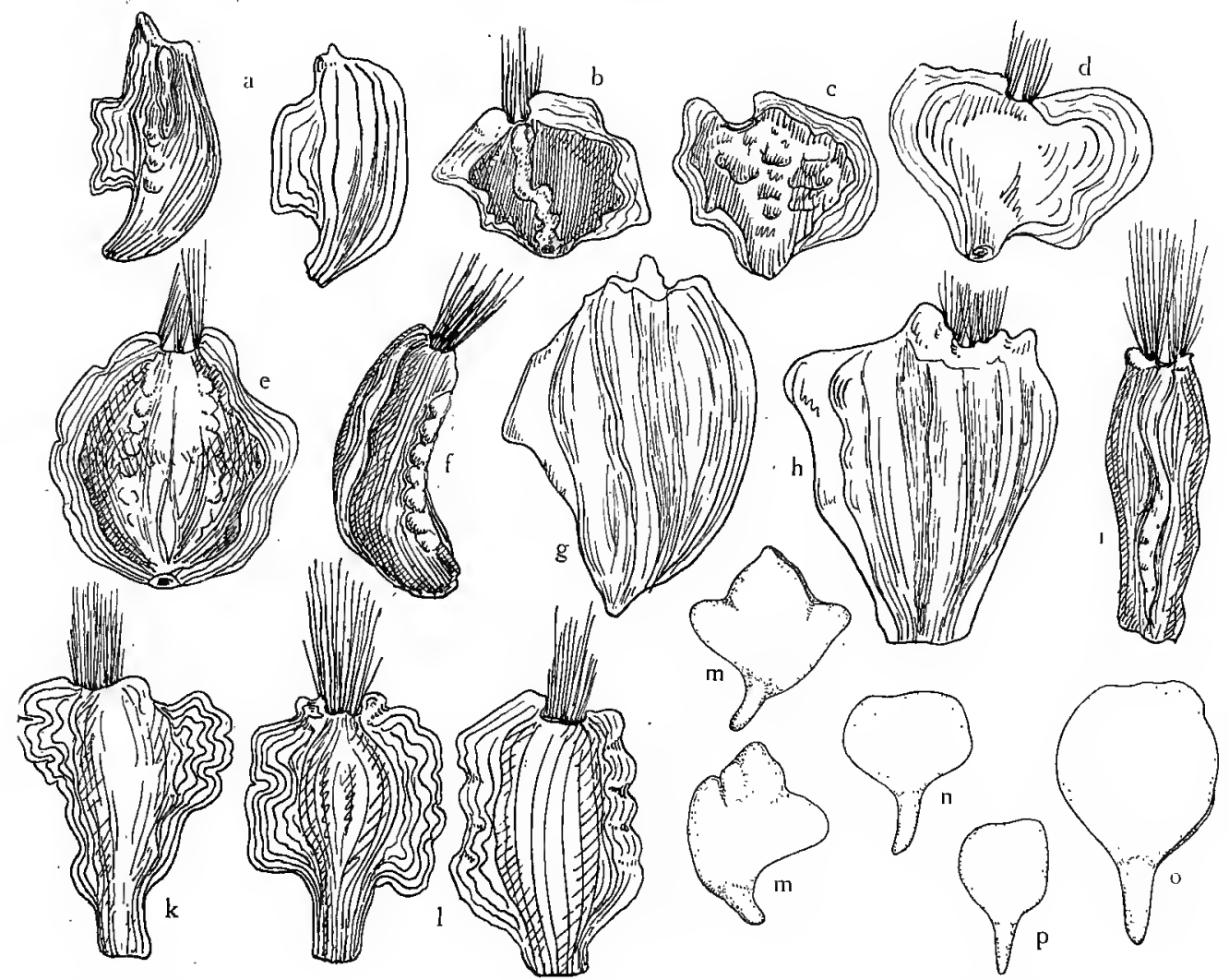

Fig. 37. Achenes $(\mathrm{a}-\mathrm{l})$ and embryos $(\mathrm{m}-\mathrm{p})$ of Dendroseris subgen. Eudendroseris. a $D$. ma. crophylla, two achenes from the side; $\mathbf{b}-\mathbf{d} D$. macrantha: b marginal achene, ventral view, c-d central achenes, side view; e-i D. marginata: e-f marginal achenes, e ventral and f lateral view; $\mathbf{g}-\mathbf{i}$ central achenes, $\mathbf{g}-\mathrm{h}$ lateral, $\mathbf{i}$ ventral view; $\mathrm{k}-\mathbf{1} D$. litoralis: $\mathbf{k}$ central achene, lateral view and 1 marginal achenes, dorsal view. $\mathrm{m}$ embryos of $D$. macrophylla, $\mathrm{n}$ of $D$. macrantha, o of $D$. marginata and $\mathrm{p}$ of $D$. litoralis. - All $\times 5$.

only differ in the leaves. BERTERO's specimens were sterile, but another collector, not quoted until now, found the inflorescence (in fruit). A specimen in Herb. Kew labelled "Rea longifolia Phil., Reed oct. 1872», consists of a leaf of $D$. micrantha and a piece of an old inflorescence of $D$. marginata.

The leaves are coriaceous, broad ovate with rounded or acuminate tip and cordate base. They are quite entire, but the edge shows scattered warts, visible on the leaf near the rock in plate 18 . The petiole is broadly alate. The upper leaves are sessile as in the former. The (hitherto undescribed) 
inflorescence is rather large, more condensed, with numerous heads; these are smaller than in the former and the involucre much more urceolate. The open head in full bloom measures $3,5 \mathrm{~cm}$ across; it only contains about 50 florets. The corolla attains a length of $40-42 \mathrm{~mm}$; the whitish tube is soft papillose in the middle part, the deep orange coloured ligule is $3-3,5 \mathrm{~mm}$ across. Anthers dark lilac brown with tails considerably longer than the gland of the filament. Style yellowish white below, upwards covered with brown papiliae, also on the back and sides of the branches, while their upper surface is clothed with low, light yellow stigma papillae. Branches of the style $4,5 \mathrm{~mm}$ long. Achenes larger than in any other species, 7 or even $8 \mathrm{~mm}$, brown, thick, with longitudinal furrows; marginal ones curved with distinct lateral wings and a ventral keel, the others with thick dorsal and ventral wings. Embryo very large, 5-6 mm long, with entire, orbicular cotyledons. Pappus turning dark rufous with age.

Area of distribution: Endemic in Masatierra.

*I36. D. litoralis nov. spec. - Syn. D. macrophylla Joh. ex p. - Plate I9; plate 20, fig. I 2 ; text fig. $37 \mathrm{k}-\mathrm{l}$, p.

Arbuscula $\mathrm{I}, 5-2 \mathrm{~m}$ alta habitu praecedentis sed truncus primarius crassior. Folia ad apicem ramorum pauca dense rosulata; lamina obscure viridis subglaucescens subtus pallidior, coriacea-carnosula, valde nervosa nervis crassis albidis, late ovata, obtusa, cordata, margine laevi \pm undulato, ad $25 \mathrm{~cm}$ longa et $18 \mathrm{~cm}$ lata; petiolus sectione triangularis crassus inferne saltem canaliculatus et marginatus, ad $12 \mathrm{~cm}$ longus. Inflorescentia terminalis late paniculata multiceps, foliosa foliis sessilibus amplexicaulibus. Pedunculi $2-4 \mathrm{~cm}$ longi. Capitula magna, florida ad $5 \mathrm{~cm}$ diam. Involucrum campanato-urceolatum, squamais externis viridi-glaucis ovato-triangulatis acutis, interioribus linearibus subhyalinis penicillatis. Receptaculum fibrillis laceratis usque ad $\mathrm{I} \mathrm{cm}$ longis munitum. Flores numerosi certe ad 100 ; corolla ad $35 \mathrm{~mm}$ longa, tubo angusto albido basi excepta molliter papilloso, ligula crocea $3-3,5 \mathrm{~mm}$ lata stylo aequilonga vel brevior. Autherae dilute flavae, caudae glandula paulo longiores. Stylus flavescens viridi-papillosus, ramis ad $4 \mathrm{~mm}$ longis. Achaenia sordide straminea, illa florum marginalium lateribus alatis ventroque carinato, cetera tenuia lateraliter valde compressa, 5-6 mm longa, basi valde angusta, sat late alata, alis dense ac longitudinaliter striatis. Embryo 3,5-4 $\mathrm{mm}$ longus, cotyledonibus integris suborbiculatis radicula paulo longioribus. Pappus sordide stramineus.

Morro Viñillo, a small rock off the south coast of Masatierra (P. ARREDONDO a. o.); cultivated specimens, raised from seeds gathered in Viñillo seen in some of the gardens in Masatierra (plate 19).

Santa Clara: Crevices in the coast cliffs of the main island, and on Morro de los Alelíes (fl.-fr. ${ }^{26} / 1$ 17, no. 342). Also observed by JoHOw.

Very near $D$. marginatu, but distinct. The leaves are thicker, with smooth edge, the heads larger with twice as many flowers, the anthers and style yellow, the tails" of the anthers shorter. The achenes are very different and the embryo considerably smaller. These achenes are mature, for I have raised numerous specimens from the portion collected by me in Santa Clara as well as from others of absolutely identical appearance gathered in the garden of ARREDONDO, who introduced the species from Morro Vinillo. My plants are all of the same 
type and agree perfectly well with the herbarium specimens as to the leaves. They are 3-4 years old but have not yet flowered.

Area of distribution: Endemic in Santa Clara and Morro Viñillo.

I37. D. pinnata (Bert. et Dene) Hook. et Arn. - JoHOw, Estud. 7 I.

Masatierra: On the higher ridges, at the limit of the forest, among shrubs and small trees, not uncommon. - Between $Q$. Laura and $Q$. de la Piedra Agujereada, c. $600 \mathrm{~m}$, large trees; El Pangal, west branch, c. $400 \mathrm{~m}$, and on the narrow crest above Pangal, c. $800 \mathrm{~m}$; north face of Co Damajuana, 500$530 \mathrm{~m}$; V. Colonial, C. Central (JoHOW), solitary in the forest down to $350 \mathrm{~m}$; Portezuelo de Villagra (JoHOW), scattered on both sides, 5-600 m, one specimen (no. I235) growing on Blechnum cycadifolium; C. Salsipuedes (JoHOW), $600-750 \mathrm{~m}$, scattered in the shrubberies (beg. f. ${ }^{8} / 1216$, no. $79-$ one single tree, all others sterile); $Q$. de los Helechos, on Dicksonia; between Q. Salsipuedes and Pto Ingles; Pto Ingles, central ridge c. $470 \mathrm{~m}$.

var. insignis Bert. ms., Johow. - Syn. Rea Berteriana Dcne. - Masatierra: $Q$. de la Piedra Agujereada, in wet forest c. $600 \mathrm{~m}$; in the gap between Damajuana and Yunque, c. $580 \mathrm{~m}$, in the humid forest, no. 164 (BERTERo no. I 505! [type] labelled „E] Yunque Majo I 830»; the Kew sheet consists of two leaves and one [complete??] inflorescence, the latter very small).

Regarding $D$. Berteriana (insignis), the material collected hitherto is very scarce. BERTERo alone has found the flowers, and very late in the season (May). The very few plants seen by us suggested a pinnata-form of extreme shade and moisture. A seedling, quite like that of typical pinnata, was found with them. The primary leaves are simple but denticulate and reniform.

Area of distribution: Endemic in Masatierra.

: 38 . D. regia nov. spec. - Plate $I 7$, fig. 2 ; text fig. 38 .

Phoenicoseris $D$. pinnatae affinis. Truncus simplex rectus ad $180 \mathrm{~cm}$ altus et $13 \mathrm{~cm}$ diam. visus, cicatricibus foliorum manifeste notatus, apice rosulam giganteam foliorum circ. $30 \mathrm{~cm}$ altam et I m latam gerens. Folia plantae juvenilis maxima, ad $150 \mathrm{~cm}$ longa et $57 \mathrm{~cm}$ lata a me visa, plantae adultae minora, $30-65 \mathrm{~cm}$ longa. Lamina crassiuscula, 3-6-pinnata, ambitu late vel latissime ovata, discolor subtus glaucescens, $24-36 \mathrm{~cm}$ longa et $16-31 \mathrm{~cm}$ lata, praecipue subtus secus nervos $\pm \mathrm{ir}$ regulariter pulverulento-pubescens mox glabra; pinnae laterales sinuato-dentatae, versus basin irregulariter et profunde dentatolaciniatae, flabellatim nervosae; terminalis triangulato-semiorbicularis basi totam latitudinem folii fere occupans, plicata, \pm profunde divisa et margine irregulariter dentata, pedato-nervosa; pinnae haud raro valde approximatae sese tegentes; petiolus ad $20 \mathrm{~cm}$ longus, crasse carnosus, inferne auriculis membranaceis pulchre reticulato venosis, versus basin angustatis, apice rotundatis et approximatis, $6-\mathrm{II} \mathrm{cm}$ longis et $0,5-2,5 \mathrm{~cm}$ latis ornatus. Cetera ignota.

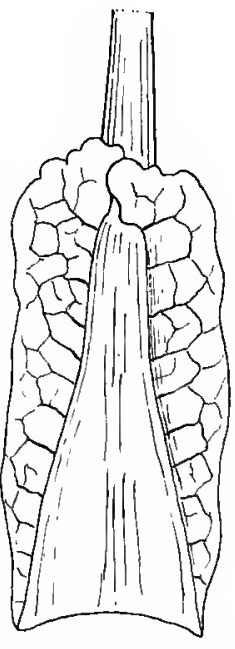

Fig. 38. Dendroseris regia, base of leaf showing auricles. $1 / 2$ nat. size. 
Masafuera: on the high ridges and in the alpine region, scattered and often associated with ferns. - Edge of western precipice above Buque Varado, c. $1250 \mathrm{~m}$; Las Torres, $1370 \mathrm{~m}$, rare; near the Correspondencia Camp 850$1130 \mathrm{~m}$, stray specimens (no. 570); C. Atravesado, c. I300 m, rare; C. del Barril, $925 \mathrm{~m}$, many specimens on the steep slope of the Vacas gorge; east slope of Los Inocentes, 740-950, also observed growing on Dicksonia.

A most noticeable plant, the second species of the hitherto monotypic subgen. Phoenicoseris, not so tall as pinnata, but more robust than this and with different leaves. In a way these resemble the leaves of var. insignis, as the pinnae lack the basal segment characteristic of pinnata proper, but otherwise they are, of course, easy to distinguish from the variety and are known by their size, laciniated margins and auricles. Unfortunately, not a single specimen flowered or was going to bloom, and not one dead tree with an old inflorescence was ever seen, so that the species cannot have flowered recently. The seedling has simple, cordate-reniform leaves, just as in D. pinnata.

Area of distribution: Endemic in Masafuera.

139. D. neriifolia (Dcne) Hook. et Arn. - Johow. Estud. 69.

Masatierra: BERTERO no. I499! Herb. Kew; leg. 1830 , mart. flor.; valleys between Pto Frances and El Pangal, especially south of El Rabanal (JoHOW!).

According to JoHOw this occurs "con bastante frecuencia» south of Rabanal. Much to our regret we never found it, in spite of a regular hunt in all directions over the tract indicated by JOHOw; undoubtedly it is very local and JoHow had good luck when he discovered it. We saw nothing but $D$. micrantha in these parts; it occurs here below the forest line in a stunted, narrow-leaved form, sometimes recalling neriifolia, but the leaves are thinner and the venation is different. The head is of about the same appearance in both, but with very few $(7-8)$ scales in neriifolia. The flowers are very much the same.

Area of distribution: Endemic in Masatierra.

I40. D. micrantha (Bert. et Dcne) Hook. et Arn. - JoHow, Estud. 68. - Fig. 39 a-c.

Masatierra: Common in the east and central parts, from Pto Frances to Co Chumacera, in forests and thickets, especially higher up on the slopes of the valleys and on the dividing ridges, $400-600 \mathrm{~m}$; also in the denser forests on steep slopes, but never seen in the high forest along the bottom of the valleys. In the eastern section, from Pto Frances to Pangal, it forms a conspicuous feature in the shubberies below the lower limit of the woods, where also the maqui is common. Here the trees are smaller, the leaves smaller and more firm and their edge generally quite entire; the inflorescence too, is smaller, but otherwise there seems to be no material difference, so I think we may explain this lowland form as a local adaption to the dry, sunny stations. Small buds $1 / 1$ I7, no. 1236 ; fl. $19 / 3$ I7, no. 567 ; fr. $28 / 317$, no. 58 I, $11 / 417$, no. $1237,17 / 417$, no. 618 .

The head is about $9 \mathrm{~mm}$ high and Io $\mathrm{mm}$ across, the funnel-shaped involucre $5 \mathrm{~mm}$ high and $4 \mathrm{~mm}$ across, composed of c. I I scales. The flower 
number 25 , more or less. The corolla is $7 \mathrm{~mm}$ long with comparatively short and broad ligule, abruptly contracted into the narrow tube. The broad, sessile, auriculate bracts are not caducous as in the next species but remain during the time of flower.

D. micrantha as is the largest of the genus, a middle-sized tree with a well developed main trunk $2-3 \mathrm{dm}$ thick.

Area of distribution: Endemic in Masatierra.

I4I. D. pruinata (Joh.) Skottsb. - D. micrantha var. pritinata, JoHow, Estud. 68. -- Fig. 39 d-f.

D. micranthae arcte affinis sed multis notis dispar. Arbor pumila rarius ultra bi- vel trimetralis, parce subdichotome ramosa. Folia sessilia amplexicaulia, oblanceolata, obtusiuscula, integerrima, subcoriacea, subtus ut cortex pedicellique pruinata. Panicula sat parva et cum illa praecedentis comparata paucicapitata, bracteis magnis auriculatis mox caducis. Capitula quam in $D$. micrantha conspicue majora, ad $14 \mathrm{~mm}$ lata et alta; involucrum campanulatum, Io mm altum et medio $7 \mathrm{~mm}$ latum dein leviter constrictum, pruinatum, squamis circ. I4, carnosis apice puberulis. Flores circ. 75, lactei. Corolla I I $\mathrm{mm}$ longa, ligula $6 \times 3,5 \mathrm{~mm}$; stamina lutea; stylus albidus ramis viridescentibus applanatis. Achaenia obovata $2,5 \mathrm{~mm}$ longa, glabra, vage costata nec non transverse rugosa, pappo $2-2,5 \mathrm{~mm}$ longo. Floret mense Januario.

Masatierra: In the dry barren coastal region, scattered; seen by us only on the south side of the island. - C. Salsipuedes (JoHOw); Pta San Carlos (JOHOW); Pto Ingles, coast rocks (JOHOW); between the foot of Co Yunque and Villagra, fine specimens in the ravines opening into the sea $(\mathrm{fl} .7 / 117$, no. 232); B. Chupones, coast rocks.

Santa Clara: Ravines of the coast cliff; Morro de los Alelies (fr. ${ }^{26} / 1$ I 7 ). Also observed by JoHow.

It is evident that the smicrantha» from the sea coast is different from the ordinary one, and at first JOHOW was inclined to regard it as a species. But as he found that plants of both, cultivated in Santiago, were too like each other, he gave up this idea and wanted to explain the special characters of pruinata as resulting from external conditions. It must not be forgotten that almost sessile leaves, more or less coated with wax, occur in young micrantha in open stations, and it is true that by the characters of the leaf $D$. pruinata is well adapted to the conditions prevailing on the sea coast, but there are differences not readily explained in this manner. $D$. pruinata bore flowers in December-January, even in places facing S., while not a single specimen of micrantha, even in the most favorable northerly exposition, flowered before the end of February. Further, the head is much larger, the flowers much more numerous, the bracts caducous etc. The achenes are a trifle smaller in micrantha and perhaps more regularly costate.

According to JoHow both forms were found growing together on Salsipuedes, and this, if correct, hardly speaks in favour of his opinion.

Area of distribution: Endemic in Masatierra and Santa Clara. 
142. D. gigantea Joh., Estud. 69; Skotrsberg, Stud. 6. - Fig. 39 g-k.

Masafiera: On the walls of the canyons and on the slopes of the valleys, in the forest region, not uncommon. Q. Sanchez, $800-880 \mathrm{~m}$, scattered; Las Chozas, in the forest near the abandoned village, $650 \mathrm{~m}$ (no. 549); Q. del Mono, c. $600 \mathrm{~m} ; \mathrm{Q}$. de las Casas, on the canyon walls, generally out of reach (Johow; Skotrsberg I908); Q. del Blindado, $370-460 \mathrm{~m}$, on steep slopes with Myrceugcnia (fl. ${ }^{19} / 2$ I7, no. 436); Q. Inocentes, c. $500 \mathrm{~m}$; Q. del Varadero, not uncommon in the smaller branch and on the slopes higher up, $650 \mathrm{~m}$.

Known before only from the Casas Valley, where Jollow obtained a few pieces by aid of a gun; by throwing stones I got hold of some leaves in the same place in 1908. It is, however, much more common in other stations and much better developed.
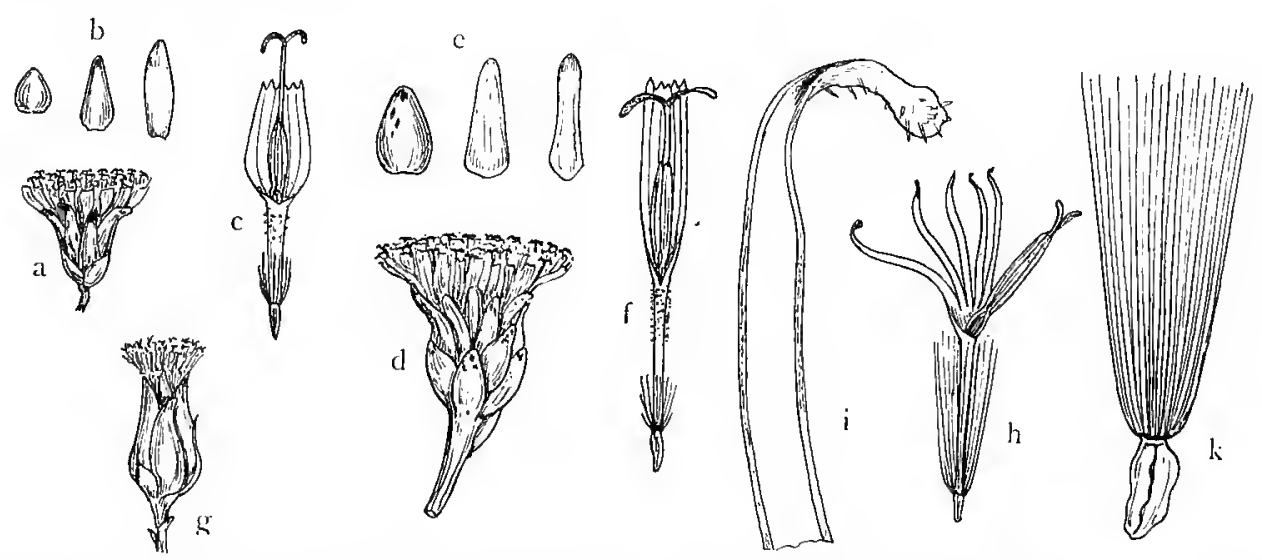

Fig. 39. a-c Dendroseris micrantha: a head, $X \mathrm{I}^{1 / 3}, \mathrm{~b}$ scales, $\times \mathrm{I}_{1}^{1 / 3}$, c floret, $\times 3^{1 / 3}$. d-f $D$. pruinata: d head, $\times \mathrm{I}^{1 / 3}$, e scales, $\times \mathrm{I}^{1 / 3}$, f floret, $\times 3^{1 / \mathrm{s}}$. $\mathrm{g}-\mathrm{k} D$. gigantea: $\mathrm{g}$ head, $\times \mathrm{I}^{1 / 3}, \mathrm{~h}$ floret, $\times 3^{1 / 3}$, i lobe of ligule, $\times 24, \mathrm{k}$ unripe achene, $\times 6^{2} / \mathrm{s}$.

Larger than most of its congeners, reaching a height of $8-10 \mathrm{~m}$; the thickest stem measured was $28,5 \mathrm{~cm}$ in diameter I $\mathrm{m}$ above the ground. The leaves not rarely attain $1 / 2 \mathrm{~m}$, those of young trees which have not yet flowered reaching enormous dimensions (largest measured $85 \mathrm{~cm}$ long, including the $4 \mathrm{~cm}$ long petiole, and $26 \mathrm{~cm}$ broad). Only old dry pieces of the inflorescence were known before. The panicles are broad ovoid and over I $\mathrm{m}$ high, and contain many thousand heads. The branches of the first and second order are supported by subsessile, ovate acuminate foliaceous bracts; those of the last order are more rigid than the others, $4-6 \mathrm{~cm}$ long, and exit under an angle of 45 to $60^{\circ}$; they bear a pseudo corymb of Io to 20 heads, each supported by a bract. The pedicels are short, with $1-3$ small bracteoles. Head narrow campanulate, $12-\mathrm{I} 3 \mathrm{~mm}$ long and about $8 \mathrm{~mm}$ across; involucre green and purple, 9-10 $\mathrm{mm}$ high, 4-5 $\mathrm{mm}$ wide above the funnel-shaped base, composed of c. I 3 scales, the outer linear-triangulate with pubescent tip, the inner almost linear, $8 \mathrm{~mm}$ long. Flowers about 25; corolla $10 \mathrm{~mm}$ long, creamy white, purplish when old; ligule split almost to its base into five narrow segments with convolute, slightly penicillate tips; stamens yellow; style hardly darker 
than the stamens, less exserted than in other species. Pappus very long, $6-7 \mathrm{~mm}$, white, later rufescent. Ovary pauci-costate; ripe achenes not seen.

While the vegetative organs seem to indicate a close affinity between D. gigantea and $D$. micrantha, the flowers show that the former occupies a rather independent position in the subgenus Rea: in fact, it differs so much from the other species, not only of this subgenus, but of the genus as a whole, that it well deserves to from a special section. The corolla is peculiar, and the pappus longer than in other species. The seedling, too, is remarkable, for the leaves are deeply incised, recalling those of the common oak.

Area of distribution: Endemic in Masafuera.

\section{Addendum.}

Since my description of Euphrasia formosissima was printed, Professor R. Wettstein kindly sent me the following remarks on this species:

"Euphrasia formosissina ist eine sehr auffallende und leicht kenntliche Art; sie unterscheidet sich von allen andern Arten schon auf den ersten Blick durch den kräftigen Wuchs, die üppige Beblätterung und die starke Verzweigung.

Sie steht der südamerikanischen Section Trifidae Benth. sehr ferne und gehört zweifellos der Section Eueuphrasia Wettst. an, welche die europäischen, asiatischen, nordamerikanischen, australischen und neuseeländischen Arten der Gattung, ferner E. grandiflora Hochst. auf den Azoren umfasst. (Vergl. R. WetTstein, Monographie der Gattung Euphrasia, I 896.)

Die Arten der Section Eueuphrasia wurden bisher auf die beiden Subsectionen Semicalcaratae Benth. und Australes Benth. verteilt, von denen die erstere die nördlich-extropischen Arten und E. grandiflora umschliesst, während der letzteren die in Australien und Neuseeland vorkommenden Arten angehören. Die beiden Subsectionen lassen sich im. Allgemeinen gut trennen, wenn auch Beziehungen zwischen einzelnen Arten der beiden Gruppen bestehen. So zeigt E. insignis Wettst. (Monogr. S. 246) aus Japan, welche zur Subsectio Semicalcaratae gehört, niclit $\mathrm{zu}$ verkennende Beziehungen zur neuseeländischen $E$. cuneata Forst. aus der Subsectio Australes. In neuerer Zeit sind aus Japan mehrere Arten der Subsect. Semicalcaratae bekannt geworden, welche eine ähnliche Stellung wie E. insignis einnehmen, so z. B. E. Matsamurae Nakai (in Fedde Repert. Spec. nov. fasc. XI p. 33, 1912) und (nach der Beschreibung) wohl auch E. Yabeana Nakai (l. c.) und E. mummularia Nakai (1. c. p. 34). Es scheint also in Japan eine reicher gegliederte Artengruppe zu existieren, welche zur Subsectio Australes hinneigt.

Dieser japanischen Gruppe von Zwischenformen zwischen den Arten der Subsectio Semicalcaratae und denen der Subsectio Australes reiht sich nun in sehr bemerkenswerter Art E. formosissina an. Sie steht einerseits der japanischen $E$. insignis Wettst., andererseits der neuseeländischen E. cuneata Forst. relativ am Nächsten.

I4-20t00. The Nat. Hist. of Juan Fernandez and Easter Isl. Vol. II. 
Von E. insignis ist sie verschieden durch den kräftigen Wuchs, die stumpfen und stumpfzähnigen, am Grunde weniger verschmälerten Blätter und Bracteen, durch die grössere Zahl der Blattzähne, durch die kürzeren und stumpfen Kelchzähne, die abgerundeten Kelchbuchten und die fast gleichlangen Spitzen der Antherenhälften. - Von E. cuneata ist E. formosissima stärker verschieden, besonders durch die sitzenden Blüten und die breiteren, am Grunde nicht so stark verschmälerten Blätter.

Es ist pflanzengeographisch und florengeschichtlich gewiss höchst beachtenswert, dass $E$. formosissima morphologisch wicht den geographisch relativ nahen südamerikanischen Arten sich anschliesst, sondern die Verbindung zwischen japanischen und neuseeländischen Formen herstellt.»

\section{Some remarks on the composition and character of the indigenous flora.}

My list contains 142 species considered to be indigenous in Juan Fernandez. Some are questionable in this respect; but, on the other hand, a few of those enumerated below as introduced might, perhaps, equally well be classed as members of the wild flora.

There are 40 natural orders (families) and $8 \mathrm{I}$ genera represented; the relation between genera and species is $I: I, 75$, a proportion to be expected in a remote insular flora, all the same if we regard it as a remnant of an old flora or brought into existence by occasional transoceanic migrations.

Of the species known before to occur in the islands seven have not been found again by us, viz. Podophorus bromoides, Trisetum chromostachyum, Cyperus reflexus, Urtica Masafuerae, Phrygilanthus Berteroi, Cardanine chenopodiifolia and Dendroseris neriffolia. In the case of Urtica and Cardamine, the season was not the proper one. On the other hand, our survey has revealed the existence in the islands of many species not found before. In 1908, 10 were added, and here $3 \mathrm{I}$ more are listed, so that the total increase amounts to about $40 \%$. It is greater still if we compare with JoHow's flora, as a few older species have been taken up again by the writer (Wahlenbergia, Dendroseris). Some species classified as indigenous by JOHOw (some, however, with hesitation) were transferred to the introduced ones.

A great deficiency in the older floras was the scarcity of exact localities. As the physical conditions are so different in different parts of these islands, in spite of their small size, it is of course quite necessary to register the stations of all the plants; further, only in this way we get an idea of the frequency of the different species. We have done our best to supply this need.

Above, 24 species and one subspecies were described as new, or were established by other authors from my material ( $L$ ncinia costata Külienth., Agrostis masafuerana Pilger, Bromus masafueranus Skottsb. et Pilger).

Only five of the new species were described from Masatierra (one, Dendroseris litoralis, also occurring in Santa Clara), the remainder all came from Masa- 
fuera. As was foreseen, not many species in Masatierra expected their discovery: two were added in 1908 and six more in $1916-17$, not counting such as were known before but have obtained their proper position in this paper /Greigia Berteroi, Halorrhagis masatierrana, Dendroseris pruinata). The meagre flora of Santa Clara was enriched by one species only (Plantago*Skottsbergii). But my. high expectations as to Masafuera were quite fulfilled. Of the 72 species now recorded from this island, 8 were discovered in 1908 and 28 in $1916-17$, which means an increase of $100 \%$. The high mountains yielded many new and interesting things. I do not flatter myself that we have come across everything, even if I am confident that future explorations will not alter the present picture of the flora very much.

In this place I wish to draw attention to certain gaps in our knowledge of some interesting plants. Of Greigia Berteroi flower and fruit are unknown; Centaurodendron has only been found with a few old achenes, and it is of considerable importance that the flowers be found. The earlier floral stages of the Gunnerc hybrids are not known. Further, nobody has seen the male flowers of Robinsonia macrocephala, and our knowledge of the flowers of Dendroseris neriffolia and $D$. pinnata var. insignis is too imperfect. All these species belong to Masatierra. Of the new species from Masafuera, Berberis masafucrana and Dendroseris regia were described from sterile specimens, and Ranunculus capramm and Fagara externa have only been found with fruit.

The distribution of the phanerogans within the Juan Fernandez group is made clear in the table below.

\begin{tabular}{|c|c|c|c|c|c|c|c|c|c|}
\hline \multirow[b]{3}{*}{$\%$ of the flora..... } & \multicolumn{2}{|c|}{ Masatierra } & \multicolumn{2}{|c|}{ Santa Clara } & \multicolumn{2}{|c|}{ Masafuera } & \multirow{2}{*}{ 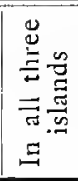 } & \multirow{2}{*}{ 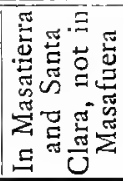 } & \multirow{2}{*}{ 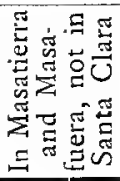 } \\
\hline & 苟 & 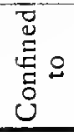 & $\stackrel{\text { ڤ్ }}{\circ}$ & 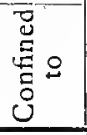 & $\begin{array}{l}\overrightarrow{\text { वే }} \\
\stackrel{0}{\circ}\end{array}$ & 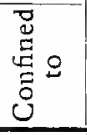 & & & \\
\hline & 96 & $\begin{array}{c}6 j \\
45 \%\end{array}$ & 9 & $\begin{array}{c}\mathrm{I} \\
0,7 \%\end{array}$ & $7^{2}$ & $\begin{array}{c}45 \\
31,7 \%\end{array}$ & $\begin{array}{c}4 \\
2,8 \%\end{array}$ & $\begin{array}{c}4 \\
2,8 \%\end{array}$ & $16 \%$ \\
\hline
\end{tabular}

We learn from these figures that there is a considerable difference between the islands. Of 142 species, only 27 , or $19 \%$, are common to Masatierra and Masafuera. The more fertile valleys of the former offer better conditions to a forest flora, while the alpine species of the latter are wanting: Masatierra is c. 950 , Masafuera c. $1500 \mathrm{~m}$ high. The poorness of the flora of Santa Clara no doubt results from very unfavorable climatic conditions; we must not forget that also the western part of Masatierra is very poor in species compared with the central and eastern parts.

The Juan Fernandez Islands are famous for their numerous and peculiar endemic types. Of the genera, $8 \mathrm{I}$ in number, only Io are endemic, but, with the exception of Ochagavia, all of them are strongly marked; Lactoris is the type of a separate order, and all the others occupy a very independent position and have no very near relatives. Further, the species of Bromus, (formerly known as Megalachne) and Eryngium (once described under the name Lessonia) form separate sections. Of 142 species not less than 98 or $69 \%$ are endemic; 
I have counted the subspecies Lusula *insularis, Margyricarpus *digynus, Dysopsis *hirsuta and Plantago *Skottsbergii among the species, while the less marked endemic forms or varieties of some species were left out of consideration.

The endemism in the different islands is illustrated below.

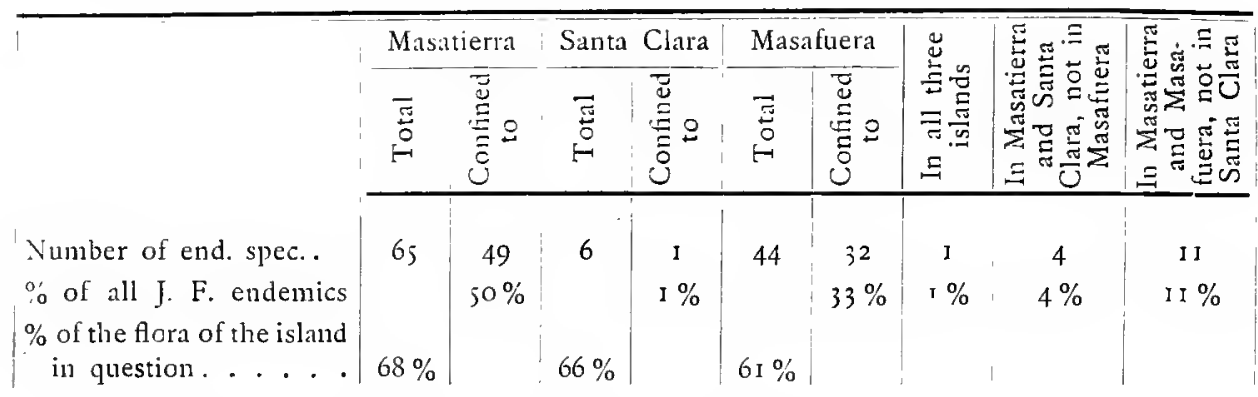

As seen above, $50 \%$ of the endemic species are found only in Masatierra, $33 \%$ only in Masafuera, and I : (Chenopodium Sanctae Clarac) only in Santa Clara; only 12 species (I2\%) are common to Masatierra and Masafuera. Thus, the floristic difference between the islands appears still more pronounced when it comes to the endemic species. And it may be added that of the Io endemic genera 8 are found exclusively in Masatierra and 2 in both islands, so that Masafuera does not possess any special endemic genus. These questions will be dealt with further in another paper.

Finally, I wish to draw attention to the fact that so many of the endemic types are very scarce; I am sure that all the existing specimens of some of the rarest plants may be counted without much labour. Of species from Masatierra, Podophorus bromoides and Plirygilanthus Berteroi have not been found by later collectors and no exact locality is known. Greigia Berteroi, Cheno. podium Crusoeanum, Erynginm inaccessum, E. fernandezianum and Dendroseris macrantha were reported from one locality each: of the latter two only 2 specimens could be found, and all are very scarce. Other very rare plants are Peperomia margaritifera, Selkirkia, Plantago fernandezia, Robinsonia thurifera and Centaurodendron. One or more of these will probably share the fate of Santalum fernandezianum, which seems to be extinct. In one or two cases I could not secure as much material as I wanted for fear of destroying the species altogether.

At present the wild flora is more or less protected, as cutting of wood for fuel is very limited and the supply mainly filled by the worst enemy of the wild flora, Aristotelia maqui; still, the consumption is far from sufficient to check the progress of the latter. To judge from Chilean newspapers, a new pcril now seems to be imminent. It is reported that Masatierra will become converted into a pleasure resort with large hotels etc. Fortunately enough, there is no good bathing beach, and much money is needed to build roads comfortable enough for the average tourist, so that there is some hope that little will be done during the present financial crisis.

In Masafuera, also some species seem to be rare. Peperomia Shottsbergii, Ranunculus capramm and Cardanine Kriisselii were found in one locality each; 
Chenopodium ne'sodendron, Robinsonia Masafuerae and Dendroseris regia are very scarce, and their recovery is checked by the too numerous wild goats. Many of the non-endemic species are also rare. Since this island was abandoned by the penal settlement in I9l4, it has remained uninhabited. Fortunately enough, the landing difficulties are very great.

The preservation of the original nature in these islands is a question of general importance to the scientific world and ought to be a matter of honour with the Chilean nation. However, many Chileans, in spite of their ardent love for their country, do not understand the necessity of the modern natureprotecting movement. In the case of Juan Fernandez, the matter, often so complicated, is much simplified, for no conflict is likely to arise between the "unpractical idealists» and the men of industry and business. It will be generally admitted that little or nothing is gained by destroying the primeval vegetation in these islands. The source of income is not agriculture but fishing, and the fishing colony will thrive even if the terrestrial fauna and flora are protected. It is true that the presence of human dwellings is undesirable, but as it is now, colonisation is limited to one valley and cannot be expected to extend much more. Certainly we cannot very well propose to remove the inhabitants.

Regarding the present international relations and other unfavorable circumstances it is probably hopeless to ask the leading scientific circles of the world to join in an action for the protection of Juan Fernandez. This is very unfortunate, for I hardly think the Chilean Government would meet an application from such institutions with complete refusal. ${ }^{1}$

My program is summarized as follows.

Protection of animal and plant life; licence to collect scientific specimens may be obtained from the Chilean Government on the recommendation of Museo Nacional in Santiago. - The rights of the colonists should be regulated and the regulations enforced. - All arrangements likely to direct a tourist traffic to the islands should be prohibited. - A Government representative with sufficient scientific training should be appointed as supervisor and provided with suitable means to fight the maqui and other noxious weeds. - The actual prohibition to kill the wild goats should be rescinded (or suspended for some years only, if it be found desirable to preserve a small stock of these animals, introduced several centuries ago and offering some historic interest). Further, the following additional measures should be taken regarding Masafuera:

Prohibition to erect permanent settlements. - The stock of goats should be cut down and not allowed to increase again, or destroyed altogether (in order to supply fresh meat in case of emergency, some other less harnful animal might be introduced).

1 Since this was written I have read in a German newspaper that the Chilean Government proposes to convert the islands into a "national park". Let us hope that the newspaper in question spealis true! 


\section{Introduced species.}

Everybody knows that it is often hard to tell if a certain species is indigenous or not in a certain place. Many circumstances have to be considered; still there are instances where a definite result cannot be obtained. In Masa. tierra large pieces of ground have become spoilt by man during the last three hundred years. It seems probable that species, even if they are true members of the Chilean flora, that only inhabit such parts or have been found only in places often visited by the inhabitants, should by classed as introduced. On the other hand, wide-spread species not belonging to the anthropoclıorous assemblage may be regarded as truly indigenous also in Juan Fernandez and were listed among the wild species in this paper. If we can rely upon the older accounts of the vegetation of Masafuera, also this island was more densely wooded in bygone times, and the removal of the forest opened a vast field for all sorts of immigrasts.

Nearly all the species enumerated below were introduced unintentionally. A few useful plants brought on purpose and which have run wild, were also included.

I. Paspalum distichum L. - JoHow, Estud. 133. - Syn. P fernandesianum Colla. - Masatierra: Bertero. - Pto Frances, B. Cumberland, Pto Ingles (JoHow). Not seen by us. - Also in Chile.

2. Setaria geniculata Roem. et Schult. - JoHOw l. c. r33. - Masatierra: B. Cumberland (JoHow). Not seen by us. - Also in Chile.

3. Setaria imberbis Roen. et Schult. - Masatierra: Douglas! V. Colonial (no. I7); Q. Juanango (no. 606). - Also in Chile.

4. Phalaris intermedia Bosc. - JoHow 1. c. I34. - Masatierra: P'to Ingles (SkotTsberG 1908). - Also in Chile.

5. Anthoxanthum odoratum L. - JoHow 1. c. 134. - Masatierra: Rather common in the hasal region; frequent in the outer parts of the valleys and extending up on the ridges (nos. 205, 246). Acc. to JoHow probably introduced during the last 50 years, as it is not in earlier collections. Masafuera: Very common, from the coast to the highest mountains, perhaps the most abundant species in the island (no. 560). - Also in Chile.

6. Polypogon crinitus Trin. - Johow l. c. 136. - Wet places, not uncommon. Masatierra: Pangal, wet moss mats in the waterfall (no. 225); B. Cumberland (JoHow), east side of V. Colonial (no. 207); Pto Ingles, wet rocks near landing place (no. 326); Q. Juanango, in the stream; stream near the foot of Co Negro. - Masafuera: Q. de las Casas, common by the small waterfalls in the gorge (no. 472); Q. Angosta and Q. del Varadero, in the same kind of station; Playa Ancha, on the flat beach (no. II85); Q. de la 
Lobería, characteristic of the waterfalls (no. 495). Agrees very well with European specimens, as shown by Fig. I k. - Also in Chile.

77 . Agrostis stolonifera L. - Masafuera: Q. Angosta, at the waterfall in the gorge (no. 559). - Also in Chile:

8. Gastridium lendigerum (L.) Gaud. - SkotTsberg, Stud. 23. Masatierra: Douglas! - Common in Chile.

9. Aira caryophyllea L. - JoHow, 1. c. 137. -- Masatierra: Rather conmon in the basal region, more so in the western part (JoHOw; SkOTTSB. no. 3I, 3I b). - Masafuera: Germain; B. Toltén; Q. de las Casas (no. I I I ). Also in Chile.

Io. Aira praecox L. - JoHow 1. c. I36. - Masatierra: Moseley. Masafuera: $Q$. de las Casas (no. I10). - Not in Chile acc. to JoHow.

I I. Avena barbata Brot. - A. hirsuta Roth, JoHow 1. c. I38. Masatierra: Very common in the basal region, abundant in the dry western parts (Johow; Srotrsi. no. I30). - Santa Clara: Johow; Morro de los Alelíes. - Masafuera: East coast (JoHOw); B. Toltén. - Also in Chile.

12. Briza minor L. - Johow 1. c. I38. - Masatierra: V. Colonial (JoHOw), hills west of B. Villagra (no. 256). - Also in Chile.

I3. Poa annua L. - Johow 1. c. I38. - Masatierra: Moseley. *Masafuera: On the top of Los Inocentes, c. $1500 \mathrm{~m}$ (no. 303). - Also in Chile.

*I4. Poa pratensis L. - Masafuera: In several places on the south side, large tufts on the shore (no. 494). - Also in Chile.

I 5. Festuca dertonensis (All.) Aschers. et Graebn. - F. muralis Kth., JoHow 1. c. I39. - Masatierra: B. Cumberland, not uncommon (nos. 107, Io9, I47); Portezuelo de Villagra (no. 29); B. del Padre (JoHOw); scattered from Villagra to Pta Larga (no. 248). - Also in Chile.

I6. F. sciuroides Roth. - JoHow 1. c. I 39. - Masatierra: Moseley. Masafuera: in the higher parts (JoHOW). - Common in Chile.

17. Bromus unioloides Kth. - JoHow l. c. I39. (B. cebadilla Steud.) Masatierra: B. Cumberland (JoHOW) ${ }_{2}$ on the cemetery (no. 182); Pto Ingles; Q. Juanango (no. 607); B. del Padre (JoHOw); Plan del Yunque; Villagra (no. 237). - *Masafuera: B. Toltén (no. 467); Q. de las Casas (no. 445); on the shore from Casas to Vacas; common in the Vacas canyon; Lobería Vieja; near Las Chozas, c. $650 \mathrm{~m}$ (no. I 108). - Also in Chile. Prof. PILGer remarks in a letter to the writer: $B$. cebadilla Steud. ist eine Form von B. unioloides, bei der die Behaarung der unteren Scheiden dicht und weich ist (STEUDEL: vaginis inferioribus dense retrorsum villoso-tomentosis). Diese Form ist in Chile verbreitet». 
I 8. Lolium multiflorum Poir. - JoHow 1. c. I40. - Masatierra: B. Cumberland (JoHow); in the colony (no. I77); Pto Ingles; Plan del Yunque; B. Villagra, not uncommon (no. 249). - Masafuera: Lobería Vieja. Common in Chile.

19. Hordeum murinum L. - JoHow 1. c. 141. - Masatieria: Douglas! V. Colonial (Johow, Skotrsb.); Q. Juanango; B. del Padre (Jonow, Skoтtsb.); Plan del Yunque; Villagra (no. 236). - Santa Clara (Johow, Skоттsв.). - Masafuera: coast and mountains (Johow, Srorrsb. no. 492). - Also in Chile.

20. Hordeum nodosum L. - JoHow 1. c. 14I. -- Masatierra: Cuning, Johow. - Common in Chile.

: $_{2}$. Phrygilanthus tetrandrus (Ruiz et Pav.) Eichl. - Masatierra: Unintentionally introduced into a garden together with plants of Olea curopaca. (fl. ${ }^{28} / 4$ I7, no. 626). - Common in Chile.

22. Rumex crispus L. - JoHOW l. c. [21. - Masatierra: V. Colonial (Johow, Skоттsв. no. 204); Pto Ingles; Q. Juanango; B. del Padre (JoHow, Skotтsв.); Villagra. - Santa Clara (Johow, Skotтsв.). - Masafuera: B. Toltén; Q. de las Casas (Johow, Srotrsb.). - Also in Cliile.

23. Rumex conglomeratus Murr. - Skotrsb. Stud. 19. - "Masatierra: El Pangal (no. 223); V. Colonial (no. I205); Q. Juanango. - Masafuera: $Q$. de las Casas (no. 455); Lobería Vieja, abundant. - Also in Chile?

24. Rumex pulcher L. - Johow 1. c. 121. - Masatierra: V. Colonial (no. 20); Pto Ingles, common; south-west part (Johow, Skorrsb.). - Santa Clara: Johow, SkotTse. - Masafuera: Hills north of Casas (Johow); Q. de las Casas, abundant near entrance; $Q$. de la Lobería, forest, 175 n. -Also in Chile.

25. Rumex acetosella L. - JoHOw 1. c. 121. - Masatierra: Very abundant in the barren parts, also seen on some of the high ridges. JoHow, SiroTTsb. no. 184 . - Masafuera: Very abundant on the upper plains and hills (Johow, Skortsb.), frequent in the alpine region f. i. on Las Torres, $1370 \mathrm{~m}$. - Also in Chile.

26. Polygonum hydropiperoides Michx var. virgatum (Cham. et Schlecht.) Meisn. - JoHOw 1. c. I20. - Masatierra: JoHOw; small stream below the chapel hill (no. r24). - Common in South Chile.

27. Polygonum aviculare L. - JoHow 1. c. I 20. - Masatierra: V. Colonial (Johow, Skot'ssв. no. 209). - Common in Chile.

28. Chenopodium murale L. - JoHow 1. c. I 8 . - Masatierra: Pto Frances (Johow); B. Cumberland (Johow, Skotrsb. no. 286); Pto Ingles; B. del Padre (nos. 287, 288). - Santa Clara: Johow, SkotTsB. no. 348. Masafuera: (JoHow); B. Toltén. - Also in Chile. 
29. Chenopodium multifidum L. - Roubieva, JoHow 1. c. 119. Masatierra: Bertero; V. Colonial (Johow; Skotrsb. no. 208); B. del Padre, especially on El Puente (no. 294). - Masafuera: scattered along the coast rocks, B. Toitén, Q. del Pasto, Q. de las Casas (JoHow), Playa Ancha, Lobería Vieja. - Also in Chile.

30. Chenopodium anbrosioides L. - Listed for Juan Fernandez by REICHE, Flora de Chile VI: I. I50. - Masafuera: The colony in $Q$. de las Casas (no. 361). - My specimens belong to Ch. chilense Schrad. as described by REICIE 1. c., a more hairy form than ambrosioides. I have compared with the material in Herb. Kew, which shows considerable variation in this respect; there are specimens from Australia, that should be brought to chilense.

*31. Amaranthus chlorostachys Willd. - Masatierra: V. Colonial (no. 355). - Not quoted from Chile.

*32. Amaranthus deflexus L. - Masatierra, on roads in the colony (no. 145). - Also in Chile.

33. Monocosmia monandra (Ruiz et Pav.) Pax. - Johow 1. c. I I6. Masafuera: GERMAIN 1854. Never found again. - Not rare in waste places in Chile.

34. Stellaria media (L.) Cyr. - Johow 1. c. 117. - Masatierra: Pto Frances (Johow); B. Cumberland (Moseley, Skottsb.). - Masafuera: forest near Casas (JoHow), in the canyon; Las Torres, I370 m. - Common in Chile.

35. Stellaria cuspidata Willd. - JoHOW 1. c. I 17. - Masatierra: El Rabanal (JOHOW). Also collected by BERTERO a. o.; B. indicated this as found in the moist woods of the higher mountains, but we have never seen a trace of it, and JoHOw found it under circumstances that make it most probable that it was introduced. - Chile.

36. Cerastium caespitosum Gilib. - C. vulgatum L., JoHow 1. c. I17? - Masafuera: Q. de las Casas (Johow? Skоттsi. no. 385); Las Torres, r $370 \mathrm{~m}$. - Also in Chile.

*37. Cerastium glomeratum Thuill, - Masatierra: Portezuelo, below the pass (no. 332). - Masafuera: Q. de las Casas (no. 1207). -- Also in Chile. - Reiche calls this C. vulgatum L.; thus it is possible that JoHow meant this species and not the preceding.

38. Sagina chilensis Naud. - Johow 1. c. I17.-- Masafuera: GERMAin. Never found again. - Centr. Chile.

39. Silene gallica L. - Johow l. c. I 6 6. - Masatierra: V. Colonial (Johow, Skoтtsi.); Pto Ingles; west part (Johow). - Santa Clara: Johow, Skortsb. - Masafuera: Q. de las Casas (Johow); B. Toltén. - Also in Chile. 
40. Anemone decapetala L. - JoHow 1. c. I I 3. - Masatierra: REED acc. to JoHow. Never found again. - Widespread in Chile.

41. Ranunculus muricatus L. - JoHow 1. c. I I3. - Masatierra: Dolgr.as etc.; V. Colonial (no. I I7); B. Villagra. - Also in Chile.

42. Lardizabala biternata Ruiz et Pav. - JoHow I. c. I I5. - Masatierra: Plazoleta del Yunque (Johow, SkotTsk, no. 482 q). - Occurs in great quantity on a very small area, forming an entangled mass resting on the trees and shrubs like a heavy net and almost killing them. It was first recorded by JoIIow who says it grows in the forest at the foot of the Yunque, especially in the Plazoleta. As far as I have been able to ascertain, the latter place is the only locality known to the inhabitants, and $I$ think it is limited to this spot. At first it appeared strange that a plant so admirably adopted to the mild climate of Masatierra should not have spread through the forests, but the explanation was soon found. The islanders are very familiar with the edible fruit of this on the continent, and they told me that the plant never produces any fruit in Juan Fernandez. In the end of March I found the flowers: all were female and not a single male one could be discovered; Lardizabala is dioecious, and there are only female plants in the island. This makes JoHow's theory that it has been introduced quite probable, if on purpose or not; the former possibility has to be considered, as A. VON RODT planted trees (Eucalypts etc.) on the Plazoleta. In any case, the Lardizabala in Masatierra comes from few seeds, all female (or perhaps from a single one?). I hope that the male plant will never be introduced. - Chile.

43. Sisymbrium officinale (L.) Scop. - JoHow 1. c. I IO. - Masatierra: B. Cumberland (Johow, SkotTș. no. 203). - Common in Chile.

44. Brassica nigra (L.) Koch. - JoHow 1. c. Iog. - Masatierra: B. Cumberland, sla maleza mas comun» (JoHow). Seems to have disappeared. - Chile.

45. Brassica napus L. - JoHow 1. c. I IO. - Masatierra; El Rabanal (Johow); B. del Padre (Johow), common on the Puente (BÄCKSTröm no. 1210); Villagra, Q. de la Chozas, wet rocks in the forest (no. 249) and a similar place on the slope of Co Chumacera (no. 249 b). - Santa Clara (JoHow). Masafuera: Lobería Vieja, abundant and of enormous size.

*46. Brassica rapa L. - Masatierra: B. del Padre (no. I211).

47. Raphanus sativus L. - JoHow 1. c. I IO. - Masatierra: Has almost disappeared since the visit of JoHow; seen by us only in B. del Padre. Masafuera: Q. de las Casas, in the colony; Lobería Vieja.

48. Nasturtium aquaticum (L.) Wg. - Masatierra: V. Colonial, abundant in the streams (no. I56). Introduced on purpose; common in Chile.

49. Matthiola incana (L.) R. Br. - Masatierra: Intentionally introduced; has run wild round $B$. del Padre, going very strong in the sand on the 
Puente (no. 289); also Santa Clara (no. I 2 I2) and Morro de los Alelies, which derives its uame from it. Possibly sown by the fishermen in all these places. Masafuera: $Q$. de las Casas, the colony.

50. Fragaria chilensis Ehrh. -.. JoHow 1. c. 92. - Masatierra: Mrs. Graham etc.; V. Colonial (JOHOW) and Villagra (JOHOW); found by us in Portezuelo by the path (no. 10). - "Masafuera: in the interior of $Q$. de las Casas. Introduced with the convicts in 1909; cultivated in the gardens of the abandoned Chozas Village. - Chile.

51. Acaena argentea Ruiz et Pav. -- JoHow 1. c. 92. - Masatierra: One of the most widespread and noxious weeds, in the basal region and on the ridges, covering the ground for large stretches (no. I I3, I $3 \mathrm{~b}, \mathrm{f}$.grandiceps Bitter; no. I13 c, I71, I239). In Masatierra, it has hybridized with Margyricarpus, see above p. 133. - "Masafuera: Las Chozas; Q, de las Casas, bebind the colony (no. 459, near f. pluribracteata Bitter).

Professor BITTER remarks to this species: "Sowohl bei Pflanzen von Masatierra (Nr. II3, II3 c) als auch von Masafuera (Nr. 459) habe ich bis 6.jochige Blätter angetroffen; die untersten Blättchen waren aber meist winzig, schmal lineal, viel kleiner als die wohl ausgebildeten Nebenblätter. Die beiden auf Juan Fernandez gefundenen Formen der $A$. argentea (f. grandiceps Bitt. in Bibl. Bot. 74, S. 217 als var.) und f. pluribracteata (ibid. S. 216 ) weichen nur wenig von den festländischen Formen der in Chile weit verbreiteten Art ab, wahrscheinlich gehen sie auch in einander über; ich habe jedoch vom Festland weder so grossköpfige noch mit so auffällig zu mehreren an Schaft verteilten reducierten Blättern versehene Exemplare gesehen.»

52. Medicago sativa L. - Johow 1. c. 89. - Masatierra: Common near the colony acc. to JoHOw; not seen by us. - *Masafuera: Q. de las Casas, the abandoned settlement. - Common in Chile.

53. Medicago denticulata Willd. - JoHow 1. c. 89. - Masatierra: Douglas etc.; V. Colonial (no. 200); El Puente (no. I2 I3); Q. Juanango; B. Chupones. - *Santa Clara. - Masafuera: Las Casas, in the settlement. Also in Chile.

54. Medicago maculata Willd. - JoIIOW 1. c. 89. - Masatierra: B. Cumberland (JoHow). - Also in Chile.

*55. Medicago lupulina L. - Masatierra: V. Colonial (no. I16). Also in Chile.

56. Melilotus indicus (L.) All. - M. parviflorus Desf., JoHow 1. c. 89. - Masatierra: Douglas etc.; V. Colonial (Johow, Skottsb. no. IOI); B. del Padre and Puente (JoHow, Skotrsb. no. I2 I4); Plan del Yunque, Co Negro etc. - Santa Clara, common (Johow, Skotrsb.). - *Masafuera: Q. de las Casas, at the settlement; Lobería Vieja. - Also common in Chile.

57. Trifolium pratense L. - JoHOW 1. c. 88. -- Masatierra: B. Cumberland (JoHow). - Escaped from cultivation. Also in Chile. 
*58. Trifoliunı repens L. - Masafuera: Q. de las Casas. - Also in Chile.

59. Geranium core-core Steud. Flora XXXIX (1856) - ? G. pusillum, Johow l. c. io7. - Masatierra: Bertero, Moseley; V. Colonial (no. I 2); Pto Ingles; Q. Juanango; Q. Villagra; B. Chupones. -- In Herb. Kew, (col. lected by MOSELEY) as $G$. ?patagonicum; HemsLey called it $G$. dissectum in Chall. Rep. It is neither of these. Unfortunately, I have not scen BERTERo's specimens, from which STEUDEL's description was prepared; they came from Central Chile and Juan Fernandez. My plants agree with the short description. KNUTH's monograph in Pflanzenreich IV: 120 is, in this case, of little or no use. It is not impossible that this Geranium is indigenous in Masatierra. A G. sp. (the same?) was found by us in Masafuera, but I have no material of it.

6o. Geranium robertianum L. - JoHow 1. c. I07. - Masatierra: Moseley. - Also in Chile.

6I. Erodium cicutarium (I..) L'Hérit. - JoHOw 1. c. I07. - Masatierra: West part (JOHOW). - Santa Clara (JOHOW). - Masafuera (JOHOW). Common in Chile.

62. Oxalis laxa Hook. et Arn. var. micrantha (Bert.). - JoHow 1. c. 106. - Masatierra: Moist mountain wall in the forest of Q. de la Choza, with some other weeds (no. 258). - Chile. - This is O. laxa, leg. Moseles, Herb. Kew. JoHOW lists both laxa (GERMAIN) and micrantha (BERTERo). Chile.

63. Oxalis conniculata L. - JoHow 1. c. I05. - *Masatierra: V. Colonial (no. 119). - Masafuera: B. Toltén (no. 463); Q. de las Casas, common (Johow, Skоттsв.). - Widespread in Chile.

64. Ruta chalepensis L. var. bracteosa (DC.) Engler. - JoHow l. c. I04. - Masatierra: B. Cumberland, along the path to Pangal (no. I04; Pta San Carlos (JoHow); Tres Puntas (JoHow); Q. Juanango; B. del Padre (Johow). - Masafuera: the shore near Las Casas (Johow, SkotTsb.). - In Chile; probably intentionally introduced, as also in Juan Fernandez.

65. Euphorbia lathyris L. - SkotTsb. Stud. I8. - Masatierra: Douglas! - Also in Chile.

66. Euphorbia peplus L. - Masatierra: Common round the colony (no. I42); Pto Ingles. - Also in Chile.

67. Callitriche stagnalis Scop. - C C. verna L., JoHow 1. c. 103. Masatierra: B. Cumberland, small stream in the colony (no. I2 I5, det G. Simuelsson). - C. verna L., quoted from Chile, where it is not considered to be indigenous, probably includes more than one species.

68. Aristotelia maqui L'Hér. - JoHow 1. c. I08. - Masatierra: Forming extensive shrubberies in the outer parts of the valleys, penetrating 
far into the primeval forests and reaching the high mountains in several places. (no. I86). - Masafuera: Near the road to Las Chozas, c. $460 \mathrm{~m}$, one shrub seen; Q. del Blindado, c. $440 \mathrm{~m}$, many specimens in the woods. As some specimens were quite stout, it is possible that the maqui was introduced before Igog, when the convict settlements were established, having escaped the attention of JoHow and the writer. But the growth is extremely rapid. - Chile.

69. Modiola caroliniana (L.) Moench. - JoHOw 1. c. IO7. - Masatierra: V. Colonial (Douglas; JoHOw; SKotTsb. no. 115). - Masafuera: Near the shore on the east side (Johow, Skotrsb.). - Also in Chile.

70. Anoda hastata Cav. - Syn. A. fernandesiana Steud. in Flora 1856 , p. 437, acc. to Reichie 1. c. I, 239. - Masatierra: BERTero. Never found again. - Also in Chile (indigenousi).

71. Malva parviflora L. - JoHow 1. c. ir8. - Masatierra: Pto Ingles; Q. Juanango; Tres Puntas. - Santa Clara (Johow; SкоTTSB. no. 346). Also in Chile.

72. Malva nicaeensis All. - JoHow 1. c. ro8. - Masatierra: V Colonial (Johow; Srotrisi. no. i8r). - Also in Chile.

73. Lythrum hyssopifolia L. - JoHOw 1. c. 97. - Masatierra: MOSELEY; V. Colonial (JoHOW; SKOTTSB. no. 121); south side of island from Plan del Yunque to Pta Larga, scattered. - Also in Cliile.

74. Ugıi Molinae Turcz. - JoHow 1. c. 94- - Masatierra: V Colonial (JoHOw); especially on the lower slopes of C. Central (no. 190), and along the path to Portezuelo, to about $200 \mathrm{~m}$; two small shrubs near the SELKIRli memorial, $590 \mathrm{~m}$; Q. Villagra, rare. Probably introduced on purpose, as the fruits are much appreciated in Chile, where the species is indigenous.

75. Oenothera mollissima L. - O.propinqua Spach, JoHOw l. c. 99. Masatierra: B. Cumberland, common in the east part of the colony (JoHow, SkotTS3. no. 14I). - ${ }^{*}$ Masafuera: Q. de las Casas. -- Indigenous in Chile. I know no better name for this; after Reiche's Flora it ought to be called $O$. stricta var. propinqua, but the stricta I have seen in herbaria seems different and is not at all so pubescent. I am afraid that REICHE's classification, based on the length of the perianth tube, does not hold good.

76. Sanicula liberta Cham. et Schlecht. - JoHow 1. c. ror. - Masatierra: REED, MOSELEy! On the slope of C. Salsipuedes, some specimens in forest at the road-side, c. $350 \mathrm{~m}$ (no. 91). - Most likely introduced, as the barbed fruits cling to the clothes. - Perú and Chile.

77. Torilis nodosa Gaertn. - Sko'TTSB. Stud. 17. - Masatierra: Douglas! - Also in Chile.

*78. Apium cfr. chilense Hook. et Arn. - Masatierra: Pta San Carlos (no. 273). - One very imperfect specimen. REICHE brought $A$. chilense to 
anstrale, probably because there are specimens of this in Herb. Santiago named $A$. chilense by Philipri. But the type of the latter in Herb. Kew clearly represents a distinct species. Possibly Ligusticum(?) fernanderianum Phil. (see REICHE, Flora III. II6) is the same as my no. 273.

*79. Apium graveolens L. - Masatierra: V. Colonial, on the beach (no. I +4 ), an escape from the gardens.

80. Apium laciniatum DC. - Srottsb. Stud. I7. -- Masatierra: V Colonial (no. 114); B. del Padre (Skottsb. 1908). - Chile. May have reached Juan Fernandez without the aid of man.

81. Petroselium sativum (L.) Hoffn1. - JoHOw 1. c. IO2. - Masatierra: GRAHAM etc.; formerly found as an escape, not seen lately. - *Masafuera: Q. Angosta, by the waterfall in the gorge.

*82. Anethum graveolens L. - Masafuera: Q. de las Casas, near the settlement; Lobería Vieja; escaped from cultivations.

*83. Ammi visnaga (L.) Lam. - Masatierra: V. Colonial (no. 178). Also in Chile.

84. Daucus australis Poepp. - JoHow 1. c. 103. - Masatierra: GERMain, Philipri. Seems to have disappeared. - Chile.

85. Anagallis arvensis L. - JoHow 1. c. 87. - Masafuera: On the shore near Casas and Vacas (Johow, Skotтsi. no. 498); Playa Ancha; Lobería Vieja. - Also in Chile.

86. Centunculus pentandrus R. Br. - JoHow l. c. 86. - Masafuera: Germain. Never found again. - Also in Chile.

87. Erythraea chilensis Pers. - JoHow 1. c. 86. - Masatierra: Common in El Rabanal and in the west part of the island acc. to JoHow: Must have disappeared, as no trace of it was seen at any time of the year, in spite of being especially searched for. - Common in Chile.

88. Convolvulus arvensis L. - Johow l. c. 86. - Masatierra: V. Colonial (Johow, Skotrsis. no. 228). - Masafuera: the abandoned village of Las Chozas. - Also in Chile.

89. Collomia gracilis Dougl. - JoHOW 1. c. 85. - Found in PHILIPPI's list of 1856 , without other indications - collected by GERMAIN? California - Chile.

90. Gilia valdiviensis Griseb. - Masafuera: Herb. Santiago! ded. Levbold (coll. by Guajardo). Never found again. - Chile.

*9I. Cynoglossum pictum Ait. - Masatierra: V. Anson, V. Colonial (no. 270), Pto Ingles, Q. Villagra. - Also in Chile. 
92. Verbena litoralis Kth. - JoHOw I. c. 79. - Masatierra: Douglas etc. In the colony (Johow; Skottsb. no. 180); Pto Ingles (Johow, SkotTsB.); Q. Juanango; Villagra; B. Chupones. - * Masafuera: Q. de las Casas near the settlement; $Q$. de la Lobería, $190 \mathrm{~m}$. - Common in Chile.

93. Marrubium vulgare L. - JoHow 1. c. 80. - Masatierra: along the path from the colony to Pangal (JoHow, SkotTsi. 110. ro3); Pto Ingles. - Masafuera: B. Toltén; Q. de las Casas (Johow, SkortsB.). - Also in Chile.

94. Melissa officinalis L. - JoHow 1. c. 80. - An escape from gardens. - Masatierra: in the colony (Johow, Skotтsв. no. 338). -- Masafuera: $Q$. de las Casas (Johow, SkotTsb.).

95. Mentha aquatica L. - Jоноw 1. c. 79. - Masatierra: in the colony (JoHOw), Plazoleta del Yunque, abundant (JoHOw). Seems to have disappeared; at least there was no trace of it in the places indicated. - Also in Chile.

*96. Mentha pulegium L. - Masafuera: round the settlement in Ias Casas (no. 462). - Also in Chile.

97. Physalis peruviana L. - Ph. pubescens R. \& P., JoHow I. c. 84. Masatierra: V. Colonial (Johow, Skоттsв. no. 166); Pto Ingles (JoHOw); Q. Juanango. - Masafuera, widely spread: B. Toltén, Las Casas, near Las Chozas, Papal (Johow, SkotTsb.), Lobería Vieja. - Also in Chile.

98. Cestrum parqui L'Hér. - Jоноw 1. c. 84. - Escaped from gardens. Masatierra: Streets of the village (JoHow, Skotrsi. no. 69); Pto Ingles. Masafuera: $Q$. de las Casas (Johow, SkortsB.). - Chile.

*99. Solanum argenteum Dun. - Escaped from gardens. - Masatierra: V. Colonial (Sкоттsв. I908). - Masafuera: near the settlement in $Q$. de las Casas. - Not reported from Chile.

* Ioo. Verbascum virgatum Stokes ex With. - Masafuera: near the settlement in $Q$. de las Casas (no. 1221) and by the road to Ias Chozas. Also in Chile.

*Ior. Veronica persica Poir. - Masatierra: V. Colonial, Q. Seca, one plant seen (no. 1217). - Also in Chile.

IO2. Plantago major L. - JoHow 1. c. 78. - Masatierra: in the colony (no. 2ro); El Pangal (JoHow); south slope of Co Chumacera, in forest. Also in Chile.

*I03. Plantago lanceolata I. - Masatierra: V. Colonial (no. I79). Masafuera: the abandoned village of Las Chozas. - Also in Chile.

*104. Galium aparine L. - Masafuera: the abandoned village of Las Chozas. - Also in Chile. 
105. Dipsacus silvestris Huds. - JoHOw 1. c. 72, as D. fullonnm L. Masatierra: B. Cumberland (JoHOW, SrotTsb. no. 269); Ito Ingles (JoHOw); Q. Juanango; Q. Villagra. - Also in Chile. My specimens agree better with $D$. silicestris, but the paleae are recurved almost as in what generally goes as D. fillomum.

106. Lobelia tupa L. - JoHow 1. c. 76. - Masatierra: V Colonial, near the cemetery (Johow, Skottsb. no. 183); between Pico Central and Pangal, many groups (Johow, Skotrsb.). - Chile.

107. Micropsis nana DC. - JoHOW 1. c. 52, - Masatierra: GERMAIN acc. to Johow; V. Colonial, rare (no. 16). - On Germain's label is indicated: "Masafuera y Juan Fernandez oct. I 854". JoHow lists Micropsis among the introduced species. - Chile.

108. Guaphalium cheiranthifolium Lam. - JoHow 1. c. 61. - Masatierra: In the dry basal region, from Pto Frances to B. Cumberland, not uncommon (SCOUler! BerTero! etc.; nos. 272, 354); C. Salsipuedes, to $750 \mathrm{~m}$ (no. 1227); Pto Ingles (Johow, Skotrsb. no. 327); La Vaquería; B. del Padre (Johow); Villagra (no. 263). - Santa Clara (Johow), Morro de los Alelíes (Skotrsb.). - *Masafuera: On the higher ridges, from the Chozas Village, c. $650 \mathrm{~m}$ (no. 430), to C. Atravesado, $1360 \mathrm{~m}$. Recently introduced, probably since 1909. - Chile.

I09. Gnaphalium aldunateoides Remy. - JoHow l. c. 62. - Masafuera: Germain, JoHow, near the landing place. - Chile.

I 0 . Gnaphalimm stachydifolium Lam. - JoHow 1. c. 62. - Masatierra: Co Piramide, c. $600 \mathrm{~m}$ (no. I91); Pta San Carlos (JoHow); C. Salsipuedes, c. $730 \mathrm{~m}$ (no. 93); l'to Ingles (JoHow'); Villagra (no. 254). - Santa Clara (JoHow). - Masafuera: $Q$. de las Casas (no. 444). - Chile. My specimens are quite like $G$. Bertirimum DC. (BERTERo no. IO29, Herb. Kew!), a species generally reduced to stachydifolium. JoIIOW's material under this name belongs in part to the next.

"I I Gnaphalium spicatum Lam. - Masatierra: V. Colouial (no. I 8 , 1229). Masafuera: $Q$. de las. Casas (no. 454), in the alpine region, $700-1200 \mathrm{n}$, only few seen (no. 1228). - There are at least three forms in my collection. - Also in Chile.

I 2. Erigeron canadensis L. - SkotTsi. Stud. 5. - Masatierra: Q. Juanango; B. del Padre (Skotrsb. 1908). - Santa Clara and Morro de los Alelíes (no. 1230, leg. Вӥскsтröm). - Masafuera: Q. de las Casas. Also in Chile.

*I13. Erigeron linifolius Willd. - Masatierra: B. del Padre (no. 29I: "typisches Ex, von E. linifolius", F. VIERHAPPER in sched.). - Also in Chile? E. strictus Hook. et Arn., a dubious species acc. to REICHE, was quoted for Juan Fernandez, leg. Scouler, by HoOker and ARnotT, Comp. Bot. Mag. II. 50. Most likely this refers to a specimen in Herb. Kew. named Conysa 
ambigua DC., and collected by Scouler; $C$. ambigua is a synonym of $E$. linifolius.

*14. Xanthium spinosum L. - Masatierra: On a road in the colony (no. 627). --- Also in Chile.

I I5. Bidens leucantha (L.) Willd. - JoHow 1. c. 52. - Masatierra: ReEn; Pto Frances (Quensel I908); V. Colonial (Sko'rtsb. 1908). Centr. Chile.

I16. Galinsoga parvifiora Cav. - Jollow 1. c. 53. - Masatierra: Germain. - *Masafuera: B. Toltén, a small hispid specimen (no. 469). Also in Chile.

I 17. Amblyopappus pusillus Hook. et Arn. - JOHOW 1. c. 53. Masatierra: B. del Padre, especially on the Puente (no. 290); west parts of the island (Johow). - Santa Clara: Johow; Morro de los Alelíes (Johow, Skotrsb.). - Perú - Chile. In Stud. 29 I listed this among the indigenous species. JoHOw supposed that it had been accidentally introduced, and I now agree with him. It is hardly probable that a plant, so numerous in places and quite conspicuous on account of the barren soil, should not have been collected before JoHow. Known in Chile for its medicinal properties, and perhaps intentionally introduced to the islands.

I18. Bahia ambrosioides Lag. - JoHow 1. c. 52. - Masafuera: Entrance to $Q$. de las Casas, extending a few hundred meters to the north and a little to the south of this place (Guajardo, Johow, SkotTsb. no. 443). The limited distribution of this species, confined to a place where almost every visitor lands (if he is able to), makes me believe that it was introduced with the traffic. It is also noteworthy that Bahia is not in GERMAIN's collection. Still, there is perhaps as much reason to call it indigenous. - N. and Centr. Chile.

*I 19. Anthemis cotula L. - Masatierra: B. Cumberland, between stones on the shore (no. 143). - Masafuera? no material preserved. - Also in Chile.

* I20. Cotula australis Hook. fil. - Masatierra: B. Cumberland (Fuentes, April 19I1, Herb. Santiago!). - Masafuera: Q. de las Casas (no. 1231). - Widespread, also in Chile.

* 121 . Senecio vulgaris L. - Masatierra: Q. Salsipuedes (no. 63I). Masafuera: $Q$. de las Casas, in the settlement (no. 419). - Also in Chile.

*I22. Cirsium lanceolatum (L.) Scop. - Masafuera: El Papal, near the old huts. - Also in Chile.

*I23. Cynara cardunculus L. - Masafuera: the abandoned village of Las Chozas. - Also in Chile.

I 24. Silybum Marianum Gaertn. - JoHow 1. c. 64. - Masatierra: Douglas etc. Very abundant in the bottom of valleys from Pto Frances to I 5 - 2nco. The Nat. Hist. of Juan Fernandez and Easter Isi. Vol. II. 
El Puente and also on the south side of the island; one of the dangerous weeds (no. I97). - Masafuera: Q. de las Casas (Jorow, Skotrsr.), Papal, Lobería Vieja. - Also common in Chile.

125. Centaurea melitensis L. - JoHow 1. c. 64. - Masatierra: Dovgl.AS etc. Pta San Carlos (no. 27r); Pto Ingles; B. del Padre (Johow, Skottsb. no. 292). - Santa Clara and Morro de los Alelíes. - Masafuera: Q. de las Casas; Q. de las Vacas (JoHow). - Also in Chile.

*26. Cichorium intybus L. - Masatierra: In the colony (no. I76). Masafuera: Settlement of Las Casas. --.- Also in Chile.

*I 27. Lapsana communis L. - Masafuera: Village of Las Chozas (no. 520). - Also in Chile.

I 28. Hypochoeris glabra L. - JoHOw 1. c. 65. - Masatierra: V. Colonial (no. I1I); B. del Padre (JoHow); Pta Larga. - Also in Chile.

*29. Taraxacum (officinale) fernandezianum Dahlstedt nov. spec. „Folia (basalia) oblonga - obovato-oblonga lobis latis curvatis unguiformibus approximatis praedita, lobis lateralibus in superiore margine valde convexis integris vel subintegris vel parce et minute - crebre et longius dentatis, acutis, lobo terminali in foliis exterioribus parvo triangulari vel sagittato, acutiusculo, in interioribus majore ovato-sagittato marginibus convexis integris vel subintegris, supra glabra - subglabra, subtus araneoso-pilosa. Petioli alati pallide rubroviolacei. Nervus medianus inferne rubroviolaceus superne pallidus. Pedunculi inferne rubroviolacei superne pallidiores, erecti vel decumbentes, toti vel superne araneoso-pilosi. Involucrum parvum-mediocre, saepe sat latum, obscure olivaceoviride. Squamae involucti exteriores sat numerosae angustae e basi paulo latiore lineari-lanceolatae, saepius supra squamas interiores attingentes, quam eae pallidiores, vulgo cupreo-coloratae in margine saepe araneosae, laxe adpressae vel erecto-patentes apicibus recurvis, ecorniculatae, interiores lineares magis obscurae saepe (praesertim in margine) araneoso-pilosae. Calathium parvum, ut videtur laete luteum. Ligulae marginales extus stria badio-violacea notatae. Antherae polliniferae vel polline fere carentes. Stylus luteus, stigniata obscura. Achaenium sordide stramineum inferne late spinulosum, spinulis apice dentatis squamifornibus, vel fere laeve, superne acutius spinulosum, $3-3,5 \mathrm{~mm}$ longum, I - I,7 $\mathrm{mm}$ latum, pyramide I $\mathrm{mm}$ longo, rostro 7-7,5 mm longo.» - Masatierra: in the colony (no. I22). - Masafuera: Settlement of Las Casas (no. 528). - Renuarkably enough no Taraxacum has been reported before from the islands. In a letter to the writer Dr. DAHLSTEDT remarks that the new species is not nearly related to any of the numerous Scandinavian forms. As the group Vulgaria, to which it belongs, is a Eurasiatic group without indigenous representatives in other parts of the world, it is clear that the species has been introduced to the islands. It should be mentioned that the shape of the leaves is sonewhat different in the two islands. Probably the form comes from South Europe, very likely via Chile. The Taraxaca of these parts of the world have not been studied very well. 
I30. Sonchus oleraceus L. - JoHow 1. c. 65. - Masatierra: V. Colonial (no. 167); Pto Ingles; Q. Juanango; B. del Padre (no. 293); Plan del Yunque; $Q$. de la Choza, wet rock wall in the forest, with other weeds (no. 250). - Santa Clara and Morro de los Alelíes. - Masafuera: B. Toltén; Las Casas; Playa Ancha; Lobería Vieja. - JoHow quotes Moseley as the only collector. J. referred the common Sonchus of the islands to S. fallax Wallr., most likely by a mistake, for it is hardly probable that this has disappeared and become replaced by the other. - Also in Chile.

We learn from this list that the number of weeds is great in the islands, even if some seem to have disappeared and others are scarce. Many play a very important part in the vegetation, such as Anthoxanthum odoratum, Avena barbata, Rumex acetosella, Acaena argentea, Aristotelia maqui, Gnaphalium cheiranthifolium, Amblyopappus pusillus and Silybum Marianum. The western half of Masatierra and Santa Clara are completely stocked with weeds. Also in Masafuera, some species are of great importance, as Avena barbata along the shore and Anthoxanthum and Rumex acetosella in the subalpine and alpine tracts. It is with little enthusiasm that I have had to report numerous species new to the islands. I cannot help putting this in relation to the erection of the penal colony in 1909. The traffic increased, some new weeds were brought to Masatierra and many more to Masafuera. Certainly, this island was abandoned after some years, but the weeds did not leave with the convicts. 


\section{List of literature.}

This list does not at all contain all the books and papers where plants from Juan Fernandez are mentioned. It is limited to works of greater importance for our knowledge of the flora, and also includes such papers where species from the islands are mentioned for the first time. Well-known handbooks etc. are not enumerated here.

Barnéoud, M.: Monographie générale de la famille des Plantaginées. Paris i 857 . P. fernandezia.

Bentham, G.: in DC., Prodr. XII (1848). - Cuminia.

(Bertero, C.): Notice sur l'Histoire naturelle de l'île Juan Fernandez, extraite d'une lettre de M. Bertero. - Ann. sci. nat. 1. sér., 'T. XXI. Paris 183o. Letter to Mr. Guillemin.

Blicer, G.: Die Gattung Acaena. - Bibl. Botan. 74 (1910-i I).

- - Weitere Untersuchungen über die Gattung Acaena. FeddE's Repert. X (1912).

- - Solana nova vel minus cognita V. Ibid. XI (1912).

Boort, F.: Caricis species novae vel minus cognitae. - Trans. Linn. Soc. XX (I846).

- Uncinia Douglasii Boott, in J. D. Hooker, Flora Antarctica II (1847).

De Candolle, A.: Monographie des Campanulacées. Paris 1830 .

- - Genres nouveaux appartenant à la familie des Composées ou Synanthérées. Arch. de Botanique II. Paris 18,33 .

De Candolle, A. P.: In DC. Prodr. VII (i 838). - Pernettya rigida.

Clarke, C. B.: Cyperaceae (praeter Caricinas) Chilenses. - Engler's Jahrb. XXX (IgOI).

Colla, A.: Plantae rariores in regionibus chilensibus a $\mathrm{cl}$. M. D. Bertero nuper detectae. - Mem. della R. Accad. d. scienze di Torino XXXVII (1834), XXXVIII (1835), XXXIX ( 836 ).

Decaisne, J.: Note sut un nouveau genre de Cichoriacées, recueilli par M. Bertrro dans l'île Juan Fernandez. - Arch. de Botanique I. Paris 1833.

- Monographie des genres Balbisia et Robinsonia, de la famille des Composées. - Ann. Sci. nat. 2. Sér., T. I. Paris 1834.

Don, D.: Descriptive Catalogue of the Compositae contained in the herbarium of Dr. Gillies; with some additions from other sources. - The Philos. Magazine, or Ann. of Chemistry etc., Vol. XI. London 1832. - Dendroseris.

Don, G.: A general history of the Dichlamydeous plants III. Iondon 1834. Coprosma.

Douglas, D.: A sketch of the journey to the north-western parts of North America, during the years $1824,5,6$, and 7 . - Comp. to the Botan. Magazine, by IV. I. Hooker. Vol. II. London $183^{6}$.

(-) Journal kept by Darid Douglas during his travels.... Publ. under the direction of the R. Hortic. Soc. London rai4.

Drude, O.: Juania australis in J. D. Hooker, Progr. and Cond. of the R. Bot. Gardens Kew. I884. 
Fuentes, F.: Revisiones en la Flora Chilena. Familia Juncáceas. Bolet. del Museo Nacional, Santiago I9 I 7 .

Gay, C.: Historia física i política de Chile. Botánica, 8 vols. Paris I 845-52.

Graham, Maria: Libertia formosa Grah. in The Edinb. New Philos. Journ., Oct. I 833.

Hemsley, W. B.: Report on the Botany of Juan Fernandez, the Southeastern Moluccas, and the Admiralty Islands. Rep. Scient. Results ... H. M. S. "Challenger". London I 885 .

Hooker, J. D.: Wahlenbergia tuberosa Hook. fil. - Curtus's Bot. Mag. CI (1875), tab. 6155 .

- Dendroseris macrophylla Don. - Ibid. CIV (I878), tab. 6353 .

Hooker, W. J.: Peperomia margaritifera Bert. - Icon Plant. 1, tab. 9ı. London 1837.

Hooker, W. J. and ArnorT, G. A. W.: Contributions towards a flora of South America and the islands of the Pacific. Hooker's Bot. Misc. II (1833), Journ. of Bot. I (1834), Comp. Bot. Mag. I (1 835 ), II ( 1836$)$, Journ. of Bot. III (I $84 \mathrm{I})$.

Johow, F.: Las plantas de cultivo en Juan Fernandez. - Anal. de la Univ. de Chile LXXXIV ( 1893 ).

- - Estudios sobre la Flora de las Islas de Juan Fernandez. - Santiago de Chile 1896 .

JUSSiEU, A. DE: Rapport sur la partie botanique du voyage de M. GAY au Chili. Arch. de Botanique II. Paris 1833.

KüKenthal, G: Cyperaceae novae V. - Fedde's Repert. XVI (1920).

Martius, K. von: Historia Naturalis Palmarum. München $1823-50$.

MeISNER, K. F.: Plantarum vascularium genera secundum ordines naturales digesta etc. Leipzig $1836-43$. - Rhetinodendron.

Miers, J.: On three new genera of Verbenaceae from Chile and its adjacent regions. - Trans. Linn. Soc. XXVII ( $187 \mathrm{I}$ ).

Miquel, F. A. W.: Systema Piperaceartim. Rotterdam i 843-44.

- Illustrationes Piperacearum. - Nov. Act. Acad. Caes. Leop.Carol. XIX Suppl. 1846.

Montagne, C.: Prodromus Florae Fernandezianae. Pars prima. - Ann. sci. nat. 2. sér. T. II-IV. Paris 1835 .

Müller Argov., K.: In DC. Prodr. XV: 2 (1866). - Dysopsis.

Oliver, D.: Santalum fernandezianum F. Phil. - Icon. Plant. 4, ser. V (1896), tab. 2430 .

Pferffer, H.: Conspectus Cyperacearum in America meridionali nascentium. I. Heleocharis. - Herbarium 56 (1921).

Pit.ger, R.: Über einige Gramineae der Skottsbergschen Sammlung von Juan Fernandez. - FEDDE's Repert. XVI (I920).

Philippl, F.: El árbol de sándalo de la isla de Juan Fernandez. - Anal. Mus. Nac. de Chile. 2. sección. Bot. I. Santiago I 897 .

Philippi, R. A.: Observaciones sobre la Flora de Juan Fernandez. - Anal. de la Univ. de Chile 1856 . German edition in Bot. Zeitung XIV (1856).

- Plantarum novarum chilensium centuriae. - Linnaea XXIX (1857-58), XXX. (1859-60), XXXIII $(1865-66)$.

- Descripción de algunas plantas chilenas. - Anal. de la Univ. de Chile XXVI ( 1865 ).

_- Lactoris fernandeziana Ph. - Verhandl. K. K. Zool.-bot. Ges. in Wien. XV. 1865 .

- Descripción de las plantas nuevas incorporadas ultimamente en el herbario chileno. - Anal. de la Univ. XLI (1872), XLIII (1873).

- Bemerkungen über die chilenischen Arten von Edwardsia. - Bot. Zeitung XXXI (1873).

- El sándalo de la isla de Juan Fernandez. - Anal, de la Univ. de Chile XI.VIII $(1876)$. 
Philippi, R. A.: Plantas nuevas chilenas. - Anal. de la Univ. de Chile. LXXXI (I 893$), X C(1895)$, XCIII (1896).

Reiche, C : Flora de Chile I-VI: r. Santiago i 896-igr r.

- Kleistogamie und Amphicarpie in der chilenischen Flora. - Verh. d. Dentsch. wiss. Ver. Santiago IV (Igor). - Cardamine chenopodiifolia.

_- Bals und Leben der hemiparasitischen Phrygilanthus-Arten. - Flora, XCVII $(1907)$.

Rohrbach, P.: Beiträge zur Systematik der Caryophyllineen III. - Linnaea XXXVII $(1871-73)$. - Spergularia.

Schinder, A.: Halorrhagaceae in "Pfanzenreich», IV: I 25 (1 905).

SkottsberG, C.: Juan Fernandez-öarnas sandelträd. - Svensk Bot. 'Tidskr. IV ( ( g то).

- - Vegetationsbilder von den Juan Fernandez-Inseln. - Karsten und Schenck, Vegetationsbilder, VIII. Reihe, H. 2 (1910).

- - Studien über die Vegetation der Juan Fernandez-Inseln. - K. Sv. Vetensk.Akad. Handl. Ll: 9 ( (19I4).

- La Expedición cientfíca sueca á las islas esporádicas de Chile Igr6-i7. Informe preliminar sobre los resultados botánicos. - Rev. de la Univ. de Cordoba (Argentina) IV: 8 ( 1917 ).

Steudel, E. G.: Synopsis plantarum glumacearum I-II.

- Urticeae nondum descriptae. - Flora XXXIII (1850).

- Einige Beiträge zu der Chilesischen und Peruanischen Flora, hauptsächlich nach den Sammlungen von Bertero und Lechler. - Flora XXXIV (1856).

Weddell, H. A.: Revue de la famille des Urticées. - Ann. sci. nat. 4. sér. 'T. I. Paris 1854 . 


\section{Index.}

Synonyms in italics.

Abrotanella crassipes Skottsb. . . . . . . . . . . . . . . . 188

Acaena argentea R. \& P. . . . . . . . . . . . . . . . . 219

一 masafuerana Bitter ..................... . . . . . . . . . . . . .

- ovalifolia R. \& P. . . . . . . . . . . . . . . . 133

Agrostis masafuerana Pilger . . . . . . . . . . . . . . . . . . 100

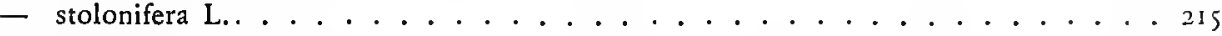

Aira caryophyllea L. . . . . . . . . . . . . . . . . 2IS

- praecox L.............................. 215

Amaranthus chlorostachys Willd. . . . . . . . . . . 217

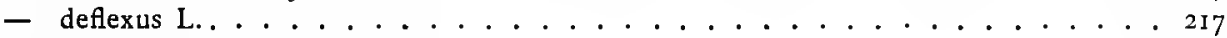

Amblyopappus pusillus H. \& A. . . . . . . . . . . . 225

Ammi visnaga (L.) Lan. . . . . . . . . . . . . . . . . . 222

Anagallis arvensis L. . . . . . . . . . . . . . . . 222

Anemone decapetala L. . . . . . . . . . . . . . . 218

Anethun graveolens L. . . . . . . . . . . . . . . . . . 222

Anoda fernandeziana Steud. . . . . . . . . . . . . . . . 221

一 hastata Cav. . . . . . . . . . . . . . . . . 22I

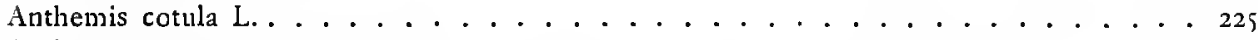

Anthoxanthum odoratun $\mathrm{L} \ldots \ldots \ldots \ldots \ldots \ldots \ldots$ 2I4

Apiun cfr. chilense H. \& A. . . . . . . . . . . . . . 22I

- fernandezianum Johow .................... . . . . . . . .

- graveolens L. ....................... . . 222

- laciniatum DC. . . . . . . . . . . . . . 222

Aristotelia maqui L'Hér. . . . . . . . . . . . . . . . 220

Avena barbata Brot. . . . . . . . . . . . . . . 215

- hirsuta Roth. ..................... 215

Azara fernandeziana Gay .......................... I45

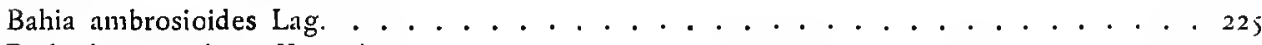

Berberis corymbosa H. \& A. . . . . . . . . . . . . . I 25

- masafuerana Skottsb. ................... . 125

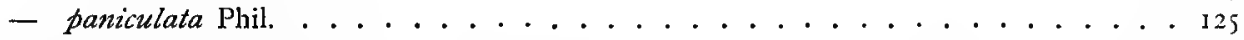

Bidens leucantha $($ L.) Willd. . . . . . . . . . . . . . . . 22j

Boehmeria excelsa Wedd. . . . . . . . . . . . . . . I I6

Brassica napus L. . . . . . . . . . . . . . . . . 21 2

- nigra (L.) Koch....................... . . 218

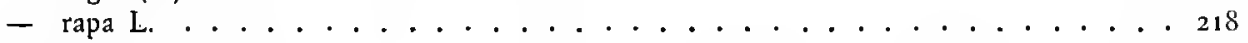

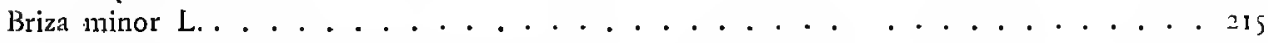

Bromus cebadilla Steud. . . . . . . . . . . . . . . . 215

- fernandezianus (Phil.) Skottsb. . . . . . . . . . . . . 102

- masafueranus Skottsb. \& Pilger ................. IO4 $_{4}$

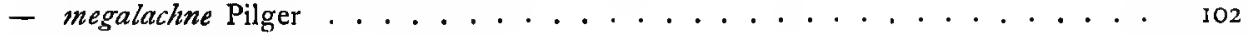

- unioloides Kth....................... 215 
Callitriclie verna L. . . . . . . . . . . . . . . . . . . 220

Calystegia Hantelmanni Phil. . . . . . . . . . . . . . . . . . I62

- tuguriorum R. Br. . .................... . 162

Campanula gracilis var. ......................... . . . 179

- Larraini Colla ..... . . . . . . . . . . . . . . . . . . 176

Cardamine alsophila Phil. . . . . . . . . . . . . . . . . . . 1 29

- chenopodiifolia Pers. . . . . . . . . . . . . . . . . . . . I28

- fernandeziana (Phil.) Johow . . . . . . . . . . . . . . . . . . . 128

- Haccida Ch. \& Schl. . . . . . . . . . . . . . . . . . . . I 29

- Krüsselii Johow .......... . . . . . . . . . . . . . . 129

Carex Banksii Boott .......................... . . 108

- Berteroniana Steud. . ........................ 108

- paleata Boott ......... . . . . . . . . . . . . . . . 108

Centaurea melitensis L. . . . . . . . . . . . . . . . . . . . . . . 226

Centaurodendron dracaenoides Johow . . . . . . . . . . . . . . . . 198

Centunculus pentandrus R. Br. . . . . . . . . . . . . . . . . . 222

Cerastiun caespitosun Gilib. . . . . . . . . . . . . . . . . . . . 2 I7

- glomeratum Thuill. . . . . . . . . . . . . . . . . . . 217

- vulgatum L. . . . . . . . . . . . . . . . . . . . . . . . 2 [ 17

Cestrum parqui L'Hér. . . . . . . . . . . . . . . . . . . . . . 223

Chaetotropis chilensis Kth. . . . . . . . . . . . . . . . . . . . . . 100

Chenopodium ambrosioides L. . . . . . . . . . . . . . . . . . . . 217

- chilense Schrad. . ................ . . . . . . . . $2 \mathrm{I} 7$

- Crusoeanum Skottsb. . . . . . . . . . . . . . . . . . . . . 119

一 multifidum L. . . . . . . . . . . . . . . . . . . . . 217

- murale L. . . . . . . . . . . . . . . . . . . . . . 216

- nesodendron Skottsb. . . . . . . . . . . . . . . . . . . Il 9

- Sanctae Clarae Johow . . . . . . . . . . . . . . . . . . . . 117

Cliusquea fernandeziana Phil. . . . . . . . . . . . . . . . . . 104

Cichorium intybus L. . . . . . . . . . . . . . . . . . . . . 226

Cirsium lanceolatum (L.) Scop. . . . . . . . . . . . . . . . . . . . 225

Citharexylon venustum Phil. . . . . . . . . . . . . . . . . . . . . . 163

Cladium scirpoideun (Steud.) B. \& H. . . . . . . . . . . . . . . . . . 106

Colletia spartioides Bert. . . . . . . . . . . . . . . . . . . . . I45

Collomia gracilis Dougl. . . . . . . . . . . . . . . . . . . . . . 222

Convolvulus arvensis L. . . . . . . . . . . . . . . . . . . . . 222

Conyza ambigua DC. . . . . . . . . . . . . . . . . . . . . . . 225

Coprosma pyrifolium (H. \& A.) Skottsb. . . . . . . . . . . . . . . . . . . I73

- triforum (H. \& A.) B. \& H. . . . . . . . . . . . . . . . . J72

Cotula australis Hook. f. . . . . . . . . . . . . . . . . . . . 225

Cuminia brevidens Bentl.. . . . . . . . . . . . . . . . . . . . . . 163

- eriantha Benth. . . . . . . . . . . . . . . . . . . . . 165

- fernandezia Colla ........................... I6f

Cynara cardunculus L. . . . . . . . . . . . . . . . . . . . . . . . . 22j

Cynoglossum pictum Ait. . . . . . . . . . . . . . . . . . . . . . 222

Cyperus fernandezianus Colla . . . . . . . . . . . . . . . . . . . . 10,

- reflexus Vahl .. . . . . . . . . . . . . . . . . . . . . . 104

— vegetus Willd. . . . . . . . . . . . . . . . . . . . . . 104

Danthonia collina Plil. . . . . . . . . . . . . . . . . . . . . 101

Daucus australis Poepp. .......................... . . 222

Dendroseris gigantea Johow . . . . . . . . . . . . . . . . . . . 208

- litoralis Skottsb. . . . . . . . . . . . . . . . . . . . 204

- macrophylla D. Don ...... . . . . . . . . . . . . . . . . . . 201

- macrantha (Bert.) Skottsb. . . . . . . . . . . . . . . . . . . 202

- marginata (Bert.) H. \& A. . . . . . . . . . . . . . . . . . . 202 
Dendroseris micrantha (Berr.) H. \& A. . . . . . . . . . . . . . 206

- mollis (Bert.) H. \& A. . . . .................. 199

- nerifolia (Dcne) H. \& A. ................... 206

- pinnata (Bert.) H. \& A. . . . . . . . . . . . . . . . . . 205

- pruinata (Joh.) Skottsb. . . . . . . . . . . . . . . . . 207

- regia Skottsb. . . . . . . . . . . . . . . . . . 20j

Dichondra repens Forst. . . . . . . . . . . . . . . . . . 162

Dipsacus fullonum L. . . . . . . . . . . . . . . . . . . . 224

— silvestris Huds. . . . . . . . . . . . . . . . . . . . . 224

Drinys confertifolia Phil. . . . . . . . . . . . . . . . . 127

- fernandeziana Steud. . . . . . . . . . . . . . . . I27

- fernandezianus Miers. . . . . . . . . . . . . . . . . I27

- Winteri Forst. var. . . . . . . . . . . . . . . . I 27

Dysopsis "hirsutal Müll. Arg. . . . . . . . . . . . . . . . . . . 144

Edwardsia fernandeziana Phil. . . . . . . . . . . . . 137, 1 40

- masafuerana Phil.................... . 137, 142

- Reedeana Phil. . . . . . . . . . . . . . . . . . . . 137 , 140

Empetrum rubrum Vahl ....... . . . . . . . . . . . . I45

Erigeron canadensis L. . . . . . . . . . . . . . . . . . 224

- fruticosus DC. . . . . . . . . . . . . . . . . 182

- Ingae Skottsb. . . . . . . . . . . . . . . . . . . . 184

- linifolius Willd. ..................... 224

- Juteoviridis Skottsb. . . . . . . . . . . . . . . . I 83

- rupicola Phil. . . . . . . . . . . . . . . . . . . 187

- turricola Skottsb. ... . . . . . . . . . . . . . . 185

Erodium cicutarium (L.) L'Hér. . . . . . . . . . . . . . . . 220

Eryngium bupleuroides $H_{1}$ \& A. . . . . . . . . . . . . . I I57

- fernandezianum Skottsb. ................. 160

- inaccessum Skottsb. . .................... . 158

- sarcophyllum H. \& A. . . . . .............. . . . . 6r

Erythraea chilensis Pers. . . . . . . . . . . . . . . . . . 222

Escallonia Callcottiae H. \& A. . . . . . . . . . . . . . . . . . . . . 129

- fernandezia Phil. . . . . . . . . . . . . . . . . . . 129

Euphorbia lathyris L. . . . . . . . . . . . . . . 220

- peplus L. ....................... 220

Euphrasia formosissinı Skottsb. . . . . . . . . . . . . . . . . . 169, 209

Fagara externa Skottsb. . . . . . . . . . . . . . . . . . 1+3

- mayu (Bert.) Engl. . . . . . . . . . . . . . . . . . . . 143

Festuca dertonensis (All.) A. \& G. . . . . . . . . . . . . . . . . 2Is

- muralis Kth. ...................... 215

- sciuroides Roth ..................... . 215

Fragaria chilensis Ehrh. ..................... 219

Galinsoga parviflora Cav. . . . . . . . . . . . . . . . 225

Galium aparine L. . . . . . . . . . . . . . . . . . . . . 223

- masafueranum Skottsb. .......................... 74

Gastridium lendigerum (L.) Gaud. . . . . . . . . . . . . . . . . 255

Geranium core-core Steud. . . . . . . . . . . . . . . . 220

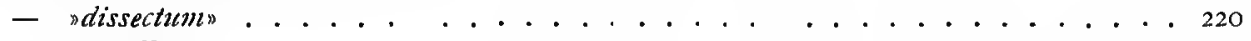

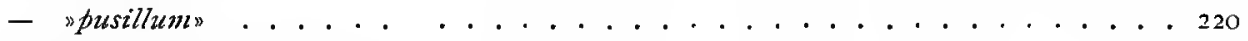

- Robertianum L. . . . . . . . . . . . . . . . . . 220

Gilia valdiviensis Griseb. . . . . . . . . . . . . . . . . . 222

Gnaphalium aldunateoides Remy . . . . . . . . . . . . . . . 224

- Berterianum DC. . . . . . . . . . . . . . . 224 
Gnaphaliun clıeiranthifoliun Lam. .......... . . . . . . . . . 224

- spicatum Lam. . . . . . . . . . . . . . . . . . . . . . 188, 224

— spiciforme Sch. Bip. . . . . . . . . . . . . . . . . . . . . I87

- stachydifolium Lam. . . . . . . . . . . . . . . . . . . . . . . 224

Greigia Berteroi Skottsb. . . . . . . . . . . . . . . . . . . . . 109

Gunnera bracteata Steud. . . . . . . . . . . . . . . . . . . . . . 148

- insularis Phil. . . . . . . . . . . . . . . . . . . . . . I48

- insularis, Schindler . . . . . . . . . . . . . . . . . . . . I47

- Masafuerae Skottsb. ....... . . . . . . . . . . . . . . I50

- peltata Phil. ............................ . I47

- pyramidalis Schindl. . . . . . . . . . . . . . . . . . 1 48

Halorrhagis asperrima Skottsb. . . . . . . . . . . . . . . . . IS3

- erecta auctt. ............................. I51

- masafuerana Skottsb. ...... . . . . . . . . . . . . . I56

- masatierrana Skottsb. . . . . . . . . . . . . . . . . . . . I5s

Heleocharis maculosa (Vahl) R. Br. ...................... . . I05

- melanocephala, Johow ........................ I05

- vincentina Clarke ... . . . . . . . . . . . . . . . . . . 105

Heterocarpus fernandezianus Phil. . . . . . . . . . . . . . . . . . . I 28

Hordeum murinum L. ..... . . . . . . . . . . . . . . . . 216

- nodosum L. . . . . . . . . . . . . . . . . . . . . 216

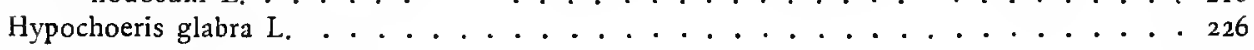

Isolepis fuscopurpurea Steud. . . . . . . . . . . . . . . . . . . . . . IOS

Juania australis (Mart.) Dr. . . . . . . . . . . . . . . . . . . . 108

Juncus acutus L. . . . . . . . . . . . . . . . . . . . . . . I12

- capillaceus Lam. . . . . . . . . . . . . . . . . . . . . II2

- Chamissonis Kth. . . . . . . . . . . . . . . . . . . . . 112

- Dombeyanus Gay ... . . . . . . . . . . . . . . . . . I I12

- fernandezianus Steud. . . . . . . . . . . . . . . . . . . . II

- imbricatus Lah. . . . . . . . . . . . . . . . . . . . . . . I I 2

- planifolius R. Br........................ . II

Koeleria micrathera (Desv.) Gris. . . . . . . . . . . . . . . . . . . IOI

Lactoris fernandeziana Phil. . . . . . . . . . . . . . . . . . . . I28

Lagenophora Harioti Franch. . . . . . . . . . . . . . . . . . . 180

- hirsuta, auctt. ........................... I80

Lapsana communis L. . . . . . . . . . . . . . . . . . . . . . 226

Lardizabala biternata R. \& P. . . . . . . . . . . . . . . . . . 2 I 8

Libertia formosa Gralı. . . . . . . . . . . . . . . . . . . . . . . . . II3

- grandiflora Phil. . . . . . . . . . . . . . . . . . . . . II3

Ligusticum fernandezianum Phil. . . . . . . . . . . . . . . . . . . . . 222

Lobelia anceps Thunb. . . . . . . . . . . . . . . . . . . . . . I80

- mpincola Colla . . . . . . . . . . . . . . . . . . . . . . I 80

- ıupa L. .... . . . . . . . . . . . . . . . . . . . . . 224

Lolium multiflorum L. . . . . . . . . . . . . . . . . . . . 2 216

Loranthus Berteroi H. \& A. . . . . . . . . . . . . . . . . . . . II6

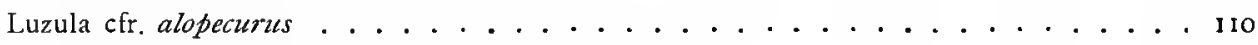

— *insularis Skottsb. . . . . . . . . . . . . . . . . . . . . I10

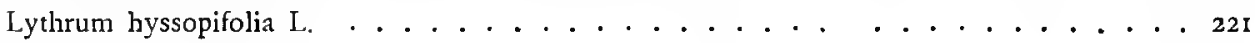

Malva nicaeensis All. . . . . . . . . . . . . . . . . . . . . 221

- parviflora L. . . . . . . . . . . . . . . . . . . . . . . 221

Margyracaena Skottsbergii Bitter . . . . . . . . . . . . . . . . . . I34

Margyricarpus digynus Bitter . . . . . . . . . . . . . . . . . . I30 
Marrubium vulgare $\mathrm{L}$.

Matthiola incana (L.) R. Br. ....................... 218

Medicrgo denticulata Willd. . . . . . . . . . . . . . . . . . . 2 J9

一 lupulina L............................ . 219

- maculata Willd. ........................... . 219

- sativa L. . . . . . . . . . . . . . . . . . . . 219

Megalachne Berteroniana Steud. . . . . . . . . . . . . . . . . . IU2

Melilotus indicus (L.) All. . . . . . . . . . . . . . . . . . . 219

- parviflorus Desf. ........................... 219

Melissa officinalis L. ........................... 223

Mentha aquatica L. . . . . . . . . . . . . . . . . . . . . . 223

- pulegium L. . . . . . . . . . . . . . . . . . . . . . . . 223

Micropsis nana DC. ........................... 224

Minulus parviflorus Lindl. var. . . . . . . . . . . . . . . . . . . I68

Modiola caroliniana (L.) Moench. . . . . . . . . . . . . . . . . . . . 221

Monocosmia monandra (R. \& P.) Pax . . . . . . . . . . . . . . . . . . 217

Myrceugenia fernandeziana (H. \& A.) Berg . . . . . . . . . . . . . . . . I47

- Schulzei Johow . . . . . . . . . . . . . . . . . . I 47

Myrteola nummularia (Poir.) Berg. . . . . . . . . . . . . . . . . . . . . I47

Nasturtium aquaticum (L.) Wg. ...................... 218

Nertera depressa B. \& S. . . . . . . . . . . . . . . . . . . . . I 12

Nicotiana cordifolia Phil. . . . . . . . . . . . . . . . . . . . . I68

Nowodworskya imberbis Phil. . . . . . . . . . . . . . . . . . . . . I00

Ochagavia elegans Phil. .......................... I10

Oenothera mollissima L. . . . . . . . . . . . . . . . . . . . . 221

- propinqua Spach ............................ 22I

Oldenlandia thesiffolia K. Schum. . . . . . . . . . . . . . . . . . . 171

Oreobolus obtusangulus Gaud. . . . . . . . . . . . . . . . . . . . . 106

Oryzopsis bicolor (Vahl) Speg. . . . . . . . . . . . . . . . . . . . . . 98

Oxalis corniculata L. . . . . . . . . . . . . . . . . . . . . . . 220

- laxa H. \& A. . . . . . . . . . . . . . . . . . . . . . . 220

- micrantha Bert. ......... ....................220

Pantathera fernandeziana Phil. . . . . . . . . . . . . . . . . . IO2

Parietaria debilis Forst. . . . . . . . . . . . . . . . . . . . . I I6

- humifusa Rich. ......... . . . . . . . . . . . . . . II6

Paronychia chilensis DC. . . . . . . . . . . . . . . . . . . . . I23

Paspalum distichum L. . . . . . . . . . . . . . . . . . . . . 214

- fernandezianum Colla . . . . . . . . . . . . . . . . . . . . 2I4

Peperomia Berteroana Miq. . . . . . . . . . . . . . . . . . . . . II4

- fernandeziana Miq. . . . . . . . . . . . . . . . . . . . . . IIS

- margaritifera Bert. . . . . . . . . . . . . . . . . . . . . 114

(

- Skottsbergi C. DC. . . . . . . . . . . . . . . . . . . . . II4

Pernettya rigida DC. . . . . . . . . . . . . . . . . . . . . I6I

Petroselinum sativum (L.) Hoffn. . . . . . . . . . . . . . . . . . . . . 222

Phalaris intermedia Bosc. . . . . . . . . . . . . . . . . . . . . 2 I4

Phrygilanthus Berteroj (H. \& A.) Reiche . . . . . . . . . . . . . . . . . . 116

— tetrandrus (R. \& P.) Eichl. . . . . . . . . . . . . . . . . . . . 216

Physalis pervviana L. . . . . . . . . . . . . . . . . . . . . . 223

- pubescens R. \& P. . . . . . . . . . . . . . . . . . . . . . . 223

Piptochaetium bicolor (Vahl) Presl . . . . . . . . . . . . . . . . . . . 98

- laevissimum Phil. .......................... . . . . . 98

Poa annua L. . . . . . . . . . . . . . . . . . . . . . . . 215 
Poa pratensis L. . . . . . . . . . . . . . . . . . . . . . . 215

Plantago fernandezia Bert. . . . . . . . . . . . . . . . . . . . I I

- lanceolata L........ . . . . . . . . . . . . . . . 223

- major L. . . . . . . . . . . . . . . . . . . . . . . . 223

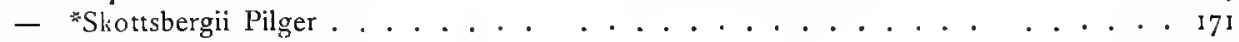

Podophorus bromoides Phil. . . . . . . . . . . . . . . . . . . 99

Polygonum aviculare L. . . . . . . . . . . . . . . . . . . . . 216

- hydropiperoides Michx .................... . . . 216

Polypogon chilensis (Kth) Pilger . . . . . . . . . . . . . . . . . 100

- crinitus Trin. ............................214

- imberbis (Phil.) Jollow . . . . . . . . . . . . . . . . . . I00

Psychotria pyrifolia H. \& A. . . . . . . . . . . . . . . . . . . I73

Ranunculus caprarum Skottsb. . . . . . . . . . . . . . . . . . 123

- muricatus L. . . . . . . . . . . . . . . . . . . . 218

Raphanus sativus L. . . . . . . . . . . . . . . . . . . . . 218

Rea Berteriana Dcne ,. ........................... 20s

Rhaphithamnus longiflorus Miers ........................ . . 163

- venustus (Phil.) Skottsb. ... ...................... I63

Rhetinodendron Berterii (Dcne) Hemsl. . . . . . . . . . . . . . . . . . 197

Rhodostachys elegans (Phil.) Mez . . . . . . . . . . . . . . . . . . . . I Io

Robinsonia evenia Phil. . . . . . . . . . . . . . . . . . . . . 193

- Gayana Dene .. . . . . . . . . . . . . . . . . . . I92

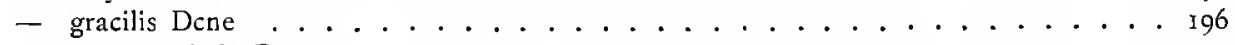

- macrocephala Dcne... . . . . . . . . . . . . . . . . . . 19I

- Masafuerae Skottsb. . . . . . . . . . . . . . . . . . . . 195

- thurifera Dcue ........................ . . . . . 192

Roubieua multifida (L.) Moq. . . . . . . . . . . . . . . . . . . . . 217

Rubus geoides Sm. ........... . . . . . . . . . . . . . . . 130

Rumex acetosella L. ........................... 216

- conglomeratus Murr. .................... . 216

- crispus L. . . . . . . . . . . . . . . . . . . . . 216

- pulcher L..................................... 216

Ruta bracteosa DC. ........................... 220

- chalepensis L. ........................ . . 220

Sagina clilensis Naud. . . . . . . . . . . . . . . . . . . . . . 2 27

Salicornia peruviana Kth . . . . . . . . . . . . . . . . . . . . . . 12 I

Sanicula liberta Ch. \& Schl. . . . . . . . . . . . . . . . . . . . . . 221

Santalum fernandezianum F. Phil. . . . . . . . . . . . . . . . . . . I17

Scirpus cernuus Vahl . . . . . . . . . . . . . . . . . . . . . . I0s

- nodosus Rottb. . . . . . . . . . . . . . . . . . . . . . 10s

Selkirkia Berterii (Colla) Hensl. . . . . . . . . . . . . . . . . . . . 163

Senecio vulgaris $\mathrm{L}$. . . . . . . . . . . . . . . . . . . . . . 225

Setaria geniculata R. \& S. ...................... 2 . . . . . 4

- imberbis R. \& S. . . . . . . . . . . . . . . . . . . . 214

Silene gallica L. . . . . . . . . . . . . . . . . . . . . . . 217

Silybum Marianum Gaertn. . . . . . . . . . . . . . . . . . . . . 22j

Sisymbrium officinale (L) Scop. . . . . . . . . . . . . . . . . . . . 218

Solanum argenteum Dun. . . . . . . . . . . . . . . . . . . . . . 223

- fernandezianum Plil. ......................... . 165

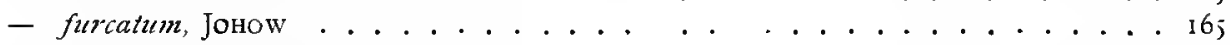

- masafueranum Bitter \& Skottsb. . . . . . . . . . . . . . . . . 167

一 Robinsonianum Bitter ... ... . . . . . . . . . . . . I65

Sonchus fallax, Johow .. . . . . . . . . . . . . . . . . . . . . . 227

- oleraceus L. . . . . . . . . . . . . . . . . . . . . . . . 227 
Sophora fernandeziana (Phil.) Skottsb. . . . . . . . . . . . . . I40

- masafuerana (Phil.) Skottsb. . . . . . . . . . . . . . . . 142

Spergularia confertiflora Steud. ... . . . . . . . . . . . I21

- polyphylla (Phil.) Rohrb. . . . . . . . . . . . . . . . . 122

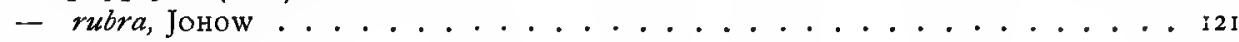

Stellaria cuspidata Willd. . . . . . . . . . . . . . 217

- media (L.) Cyr. . . . . . . . . . . . . . . . . . 217

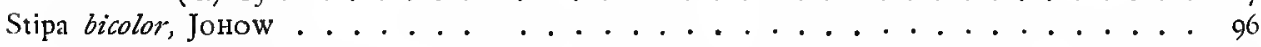

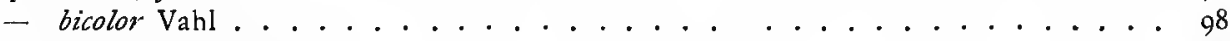

- fernandeziana Phil. ..................... . . 96

- fernandeziana Steud. . . . . . . . . . . . . . . $9^{8}$

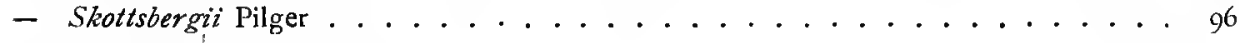

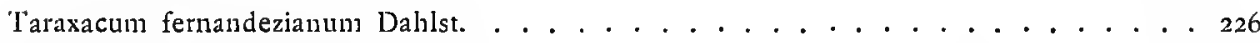

Tetragonia expansa Murr. ................... I2

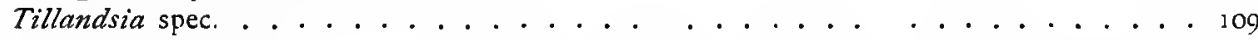

Torilis nodosa Gaertn. . . . . . . . . . . . . . . . 221

Trifoliun pratense L. ............................... 219 repens L. . . . . . . . . . . . . . . . 220

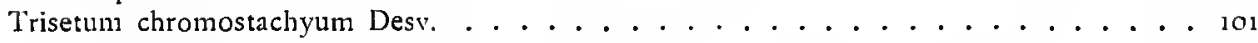

- laxum Phil. . ...................... . IOI

- micratherum Desv...................... 10 I

Ugni Molinae Turcz. . . . . . . . . . . . . . . . 221

- Selkirkii (H. \& A.) Berg. . . . . . . . . . . . . . . I46

Uncinia brevicaulis Thoulars ...................... 106

- costata Kükenth. .................... 107

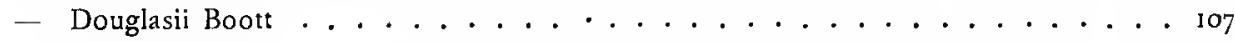

- phleoides Pers. ........................ I07

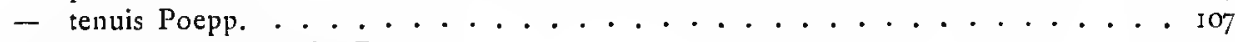

Urtica fernandeziana (Rich.) Ross . . . . . . . . . . . . . 115

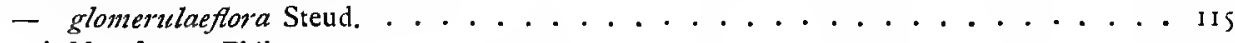

- Masafuerae Phil. ................... is

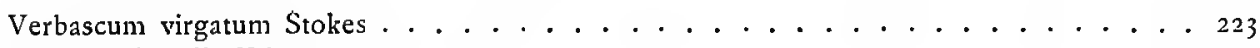

Verbena litoralis Kth .................... 223

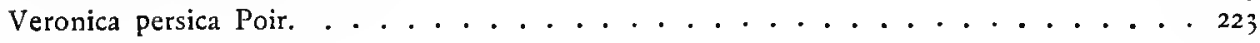

Wahleabergia Berteroi H. \& A. . . . . . . . . . . . I79

- fernandeziana (A. DC.) Skottsb. . . . . . . . . . . . . . 177

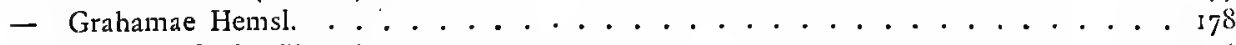

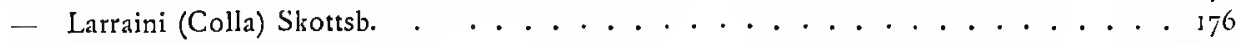

- Masafuerae (Phil.) Skottsb. . . . . . . . . . . . . 178

- tuberosa Hook. f. .......................... ${ }_{7} 8$

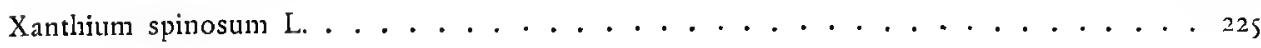

Index of species not belonging to the island flora, but mentioned (and in some cases figured) in connection with the systematic analysis.

Abrotanella linearifolia A. Gray . . . . . . . . . . . . . . . . . . 189

- Moseleyi Skottsb. . . . . . . . . . . . . . . 190

Agrostis pectinata Hack, \& Arech. . . . . . . . . . . . . . . . I00

Azara serrata R. \& P. .......................... . . . . . . . .

Drimys chilensis DC. .................... 127 
Drimys paniculata Steud. . . . . . . . . . . . . . . . . . . . . 127

Edrardsia cassioides Phil. . . . . . . . . . . . . . . . . . . . . I 39

Macnabiana Grah. .... . . . . . . . . . . . . . . I39

Gnaphalium mucronatum Phil. . . . . . . . . . . . . . . . . 188

Halorrhagis cartilaginea Cheesem. . . . . . . . . . . . . . . . . . 152

- Colensoi Skottsb. . . . . . . . . . . . . . . . . . . . . I52

- erecta (Murr.) Schindl. . . . . . . . . . . . . . . . . . . 152

Juncus microcephalus Kth. . . . . . . . . . . . . . . . . . . . . . . I12

Lagenophora hirsuta Less. . . . . . . . . . . . . . . . . . . . . I I I

- nudicaulis (Comm.) P. Dus. . . . . . . . . . . . . . . . . . I I I

- petiolata Hook. f. ......................... 182

- pumila (Forst.) Cheesem. . . . . . . . . . . . . . . . . . . . . 181

Libertia elegans Poepp. . . . . . . . . . . . . . . . . . . . . I13

Luzula chilensis Desv. .......................... . . I I I

- racemosa Desv. . . . . . . ................... I10

- vulcanica Liebm. . . . . . . . . . . . . . . . . . . . I II

Sophora grandiflora (Salisb.). . . . . . . . . . . . . . . . . . I 38

- microphylla Ait. . . . . . . . . . . . . . . . . . . . 138

- prostrata Buchan. . . . . . . . . . . . . . . . . . . . 138

- tetraptera J. Mill. . . . . . . . . . . . . . . . . . . . . 137

- toromiro (Phil.) Sliottsb. . . . . . . . . . . . . . . . . . I39

Spergularia remotiflora Steud. . . . . . . . . . . . . . . . . . . . . 121

Stipa longiflora Steud. . . . . . . . . . . . . . . . . . . . . 98

- macrathera Phil. . . . . . . . . . . . . . . . . . . . . . . 98

- manicata Desv .. . . . . . . . . . . . . . . . . . . . . 97

- Neesiana Trin. . . . . . . . . . . . . . . . . . . . . . . . 97

Vilfa muricata Presl. . . . . . . . . . . . . . . . . . . . . . . . 100

Wahlenbergia linifolia A. DC. . . . . . . . . . . . . . . . . . . . I79 


\section{Explanation of the Plates.}

Nos. 12, 13, 15, 17-19 reproduced from photographs taken by C. SkotTsberg in the islands; nos. 10, 11, 14, 16 from photographs after dried specimens by A. KarNEI.L; 10. 20 after pietures from nature by C. SkotTsBerg.

Plate 10.

I'eperomia Skottshergii C. DC. $-3 / 5$.

Plate 11.

Chenopodiusn Crusoeanum Skottsb. - $3 / 5$.

\section{Plate 12.}

I Lactoris fernandeziana Phil. below Portezuelo, Masatierra. 2 Eryngium inaciessum Skottsb. at Portezuelo, Masatierra.

\section{Plate 13.}

I Margyracaena Skottsbergii Bitter (centre and right), Acaena argentea Ruiz et Pav. (left), Valle Colonial, Masatierra. 2 Gunnera bracteata Steud. $\times$ peltata Phil., near the road to Portezuelo, Masatierra.

\section{PJate 14.}

Solanum masafueranum Bitter et Skottsb. - $\$ / 5$.

\section{Plate 15.}

I Euphrasia formosissima Skottsb., Masafuera. 2 Wahlenbergia Grahamae Hemsl,, near Portezuelo, Masatierra.

\section{Plate 16.}

I Erigeron Ingae Skottsb. 2 Erigeron turricola Skottsb. - $3 / \hbar$.

\section{Plate 17.}

I Robinsonia Masafuerae Skottsh. and 2 Dendroseris regia Skottsb, near the Correspondencia Camp, Masafuera.

\section{Plate 18.}

Dendroseris marginata (Bert.) Hook. et Arn. at Portezuelo, Masatierra. 


\section{Plate 19.}

Dendroseris litoralis Skottsb. from Morro Viñillo, in a garden in the colony, Masatierra.

Plate 20.

I-5 Seeds of Sophora: I S. fernandesiana (Phil.) Skottsb. var. Reedeana (Phil.) Skottsb.; 2 S. masafuerana (Phil.) Skottsb.; 3 "S. Macnabiana Grah.» from Chile; 4 S. microphylla Ait. from New Zealand; 5 S. toromiro (Phil.) Skottsb. from Easter Island. All nat. size. 6-7 Euphrasia formosissima Skottsb., $\times 3$. 8 Wahlenbergia Berteroi Hook. et Arn., $\times 2.9$ Wahlenbergin jernandesiana (A. DC.) Sliottsb., $\times 2$. 10 Wahlenbergia Grahamae Hemsl., $\times 2$. il Dendroseris marginata (Bert.) Hook. et Arn, $\times 5$. 12 Dendroseris litoralis Skottsb., $\times 5$. 


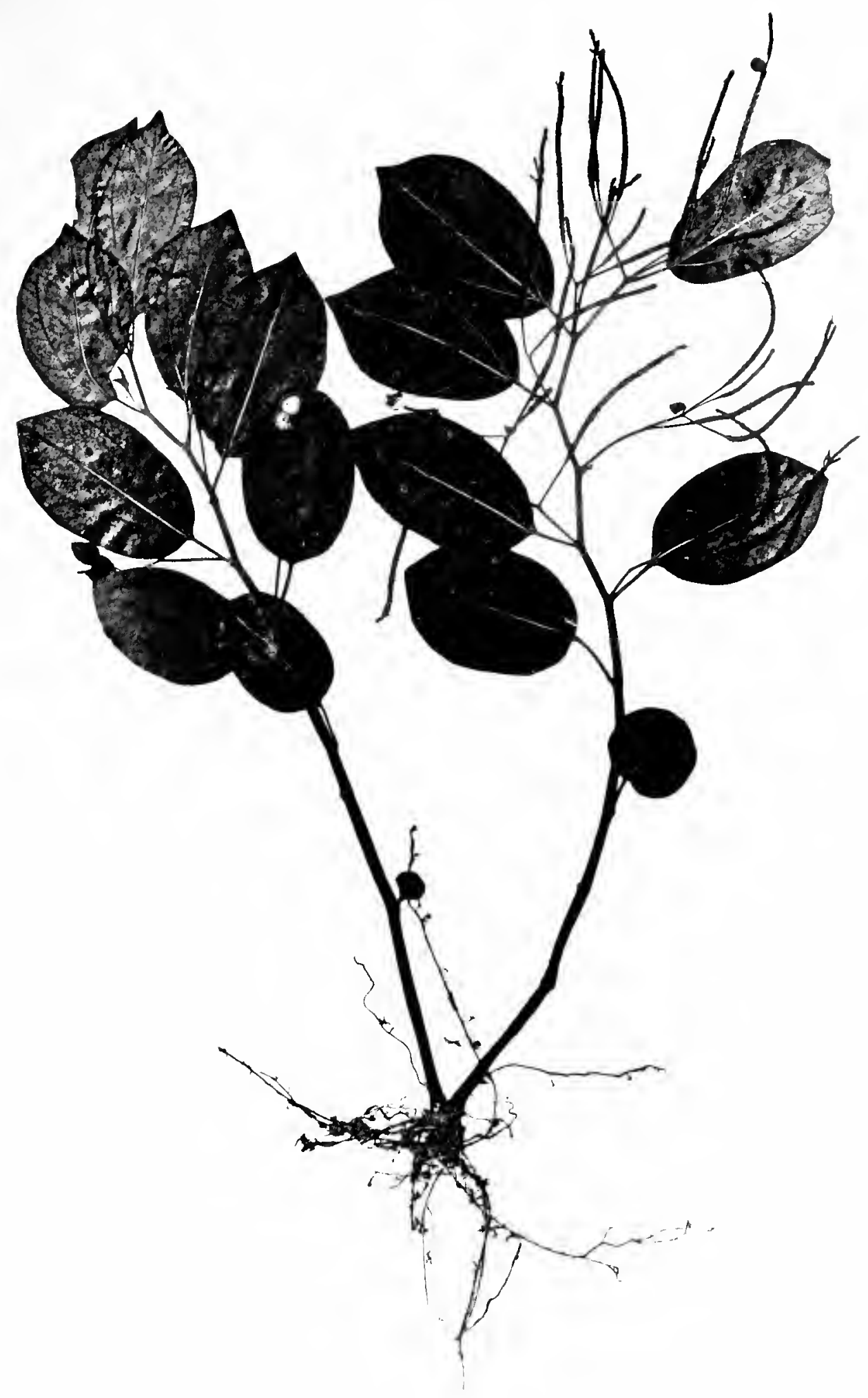





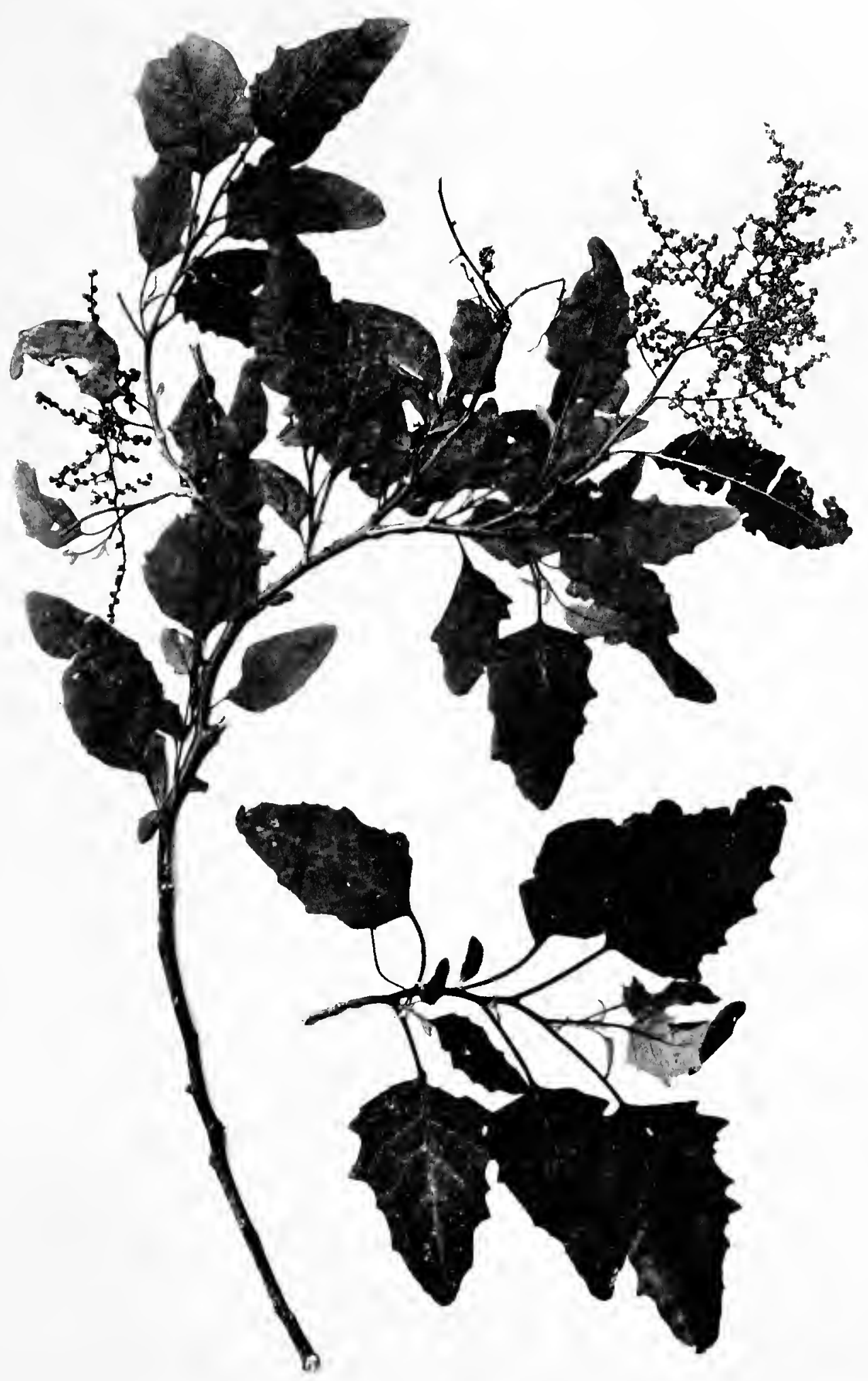




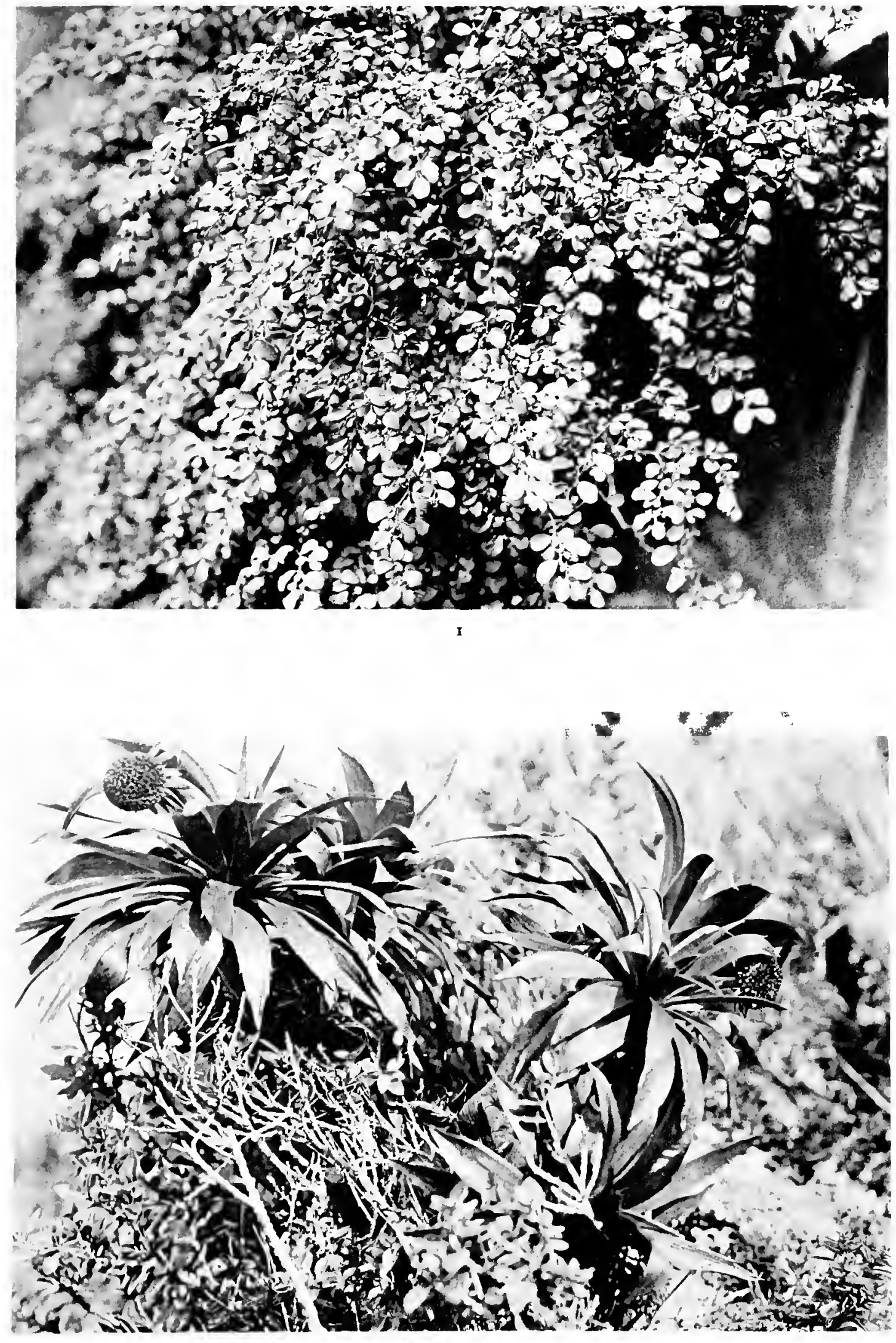

1. 1.2.

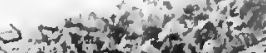
w

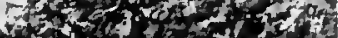

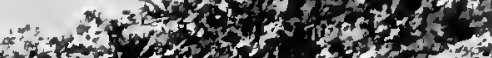

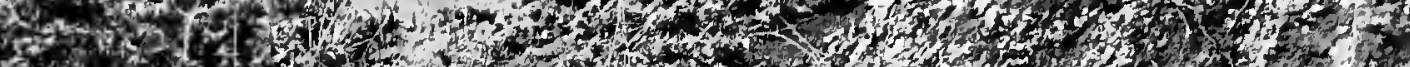

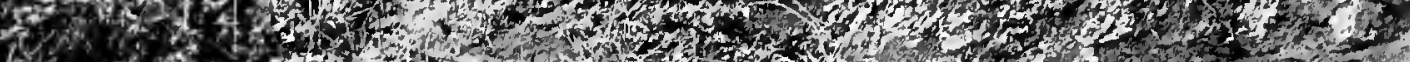

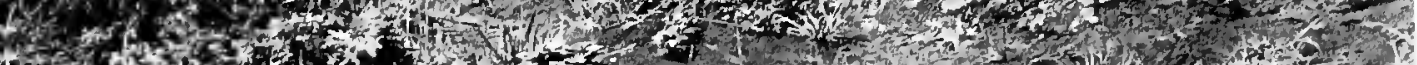

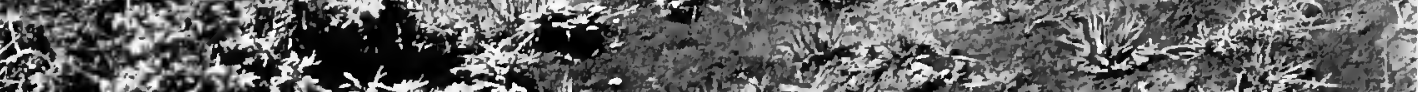

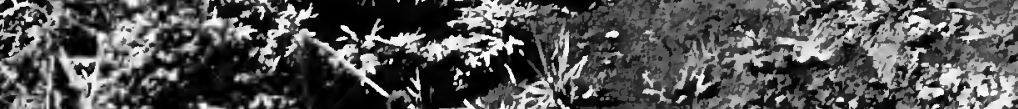

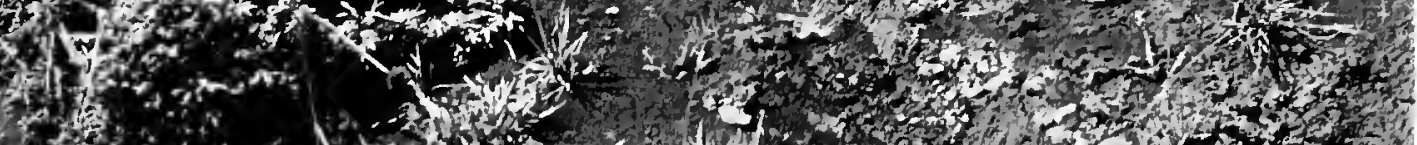

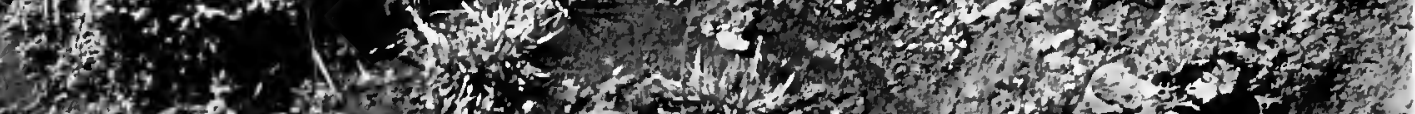

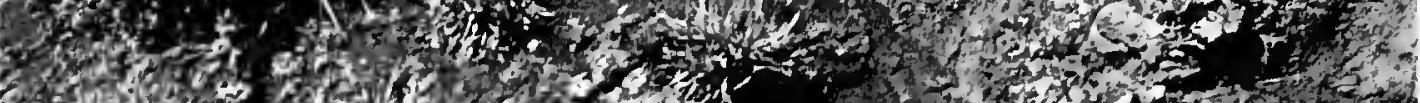

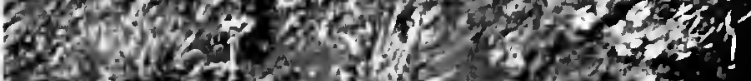

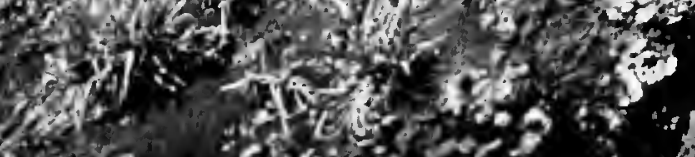

6.

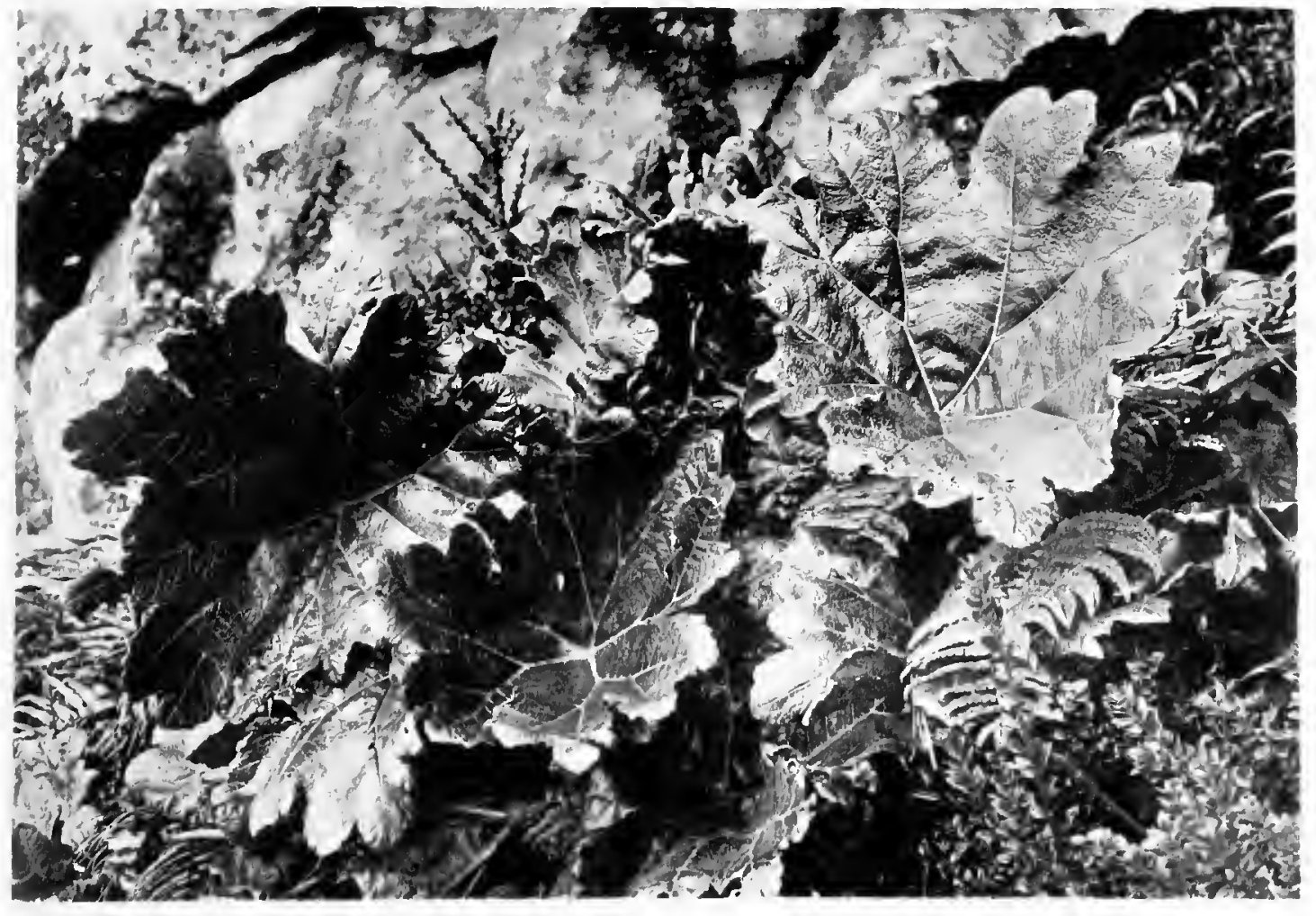





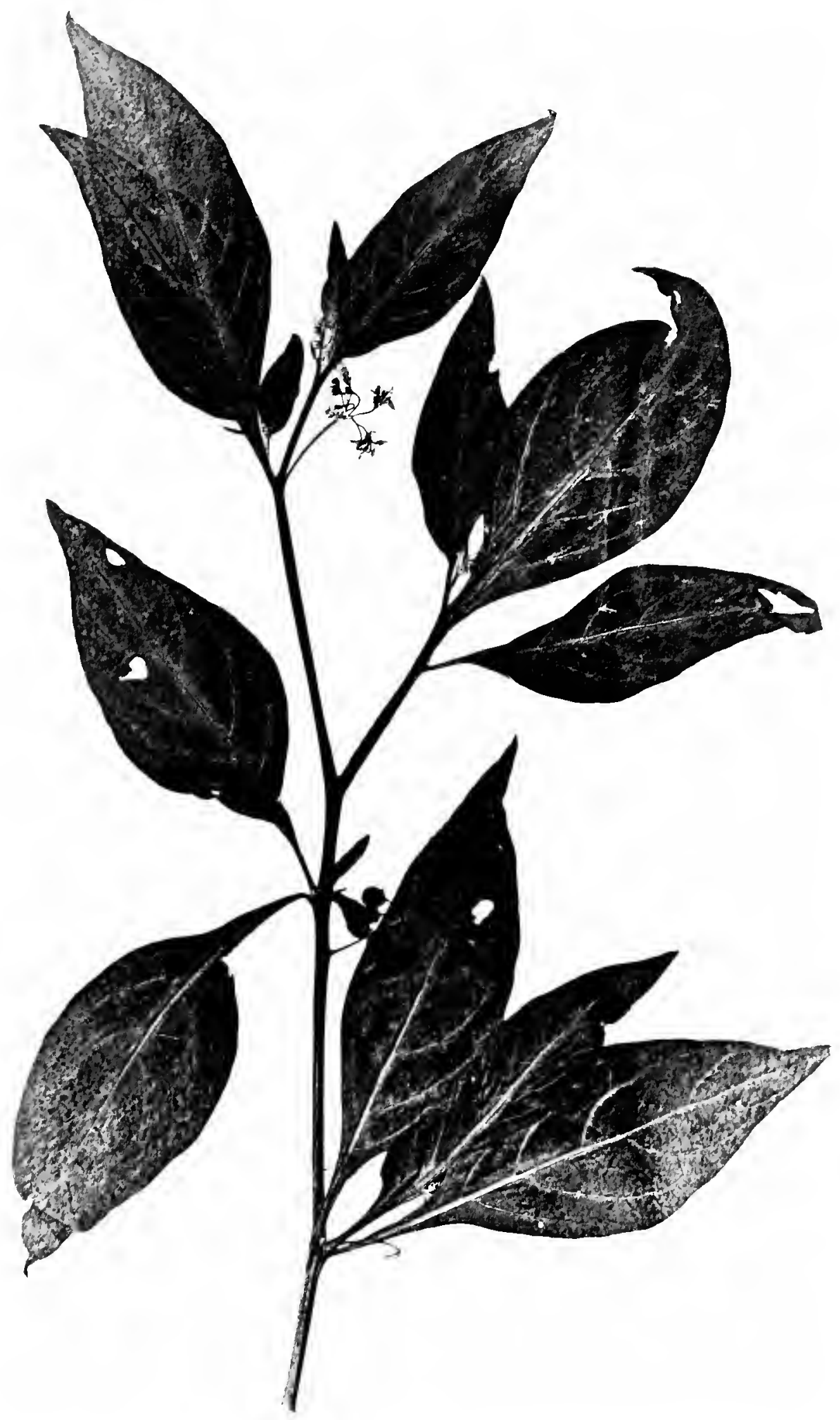


$3 x$ 

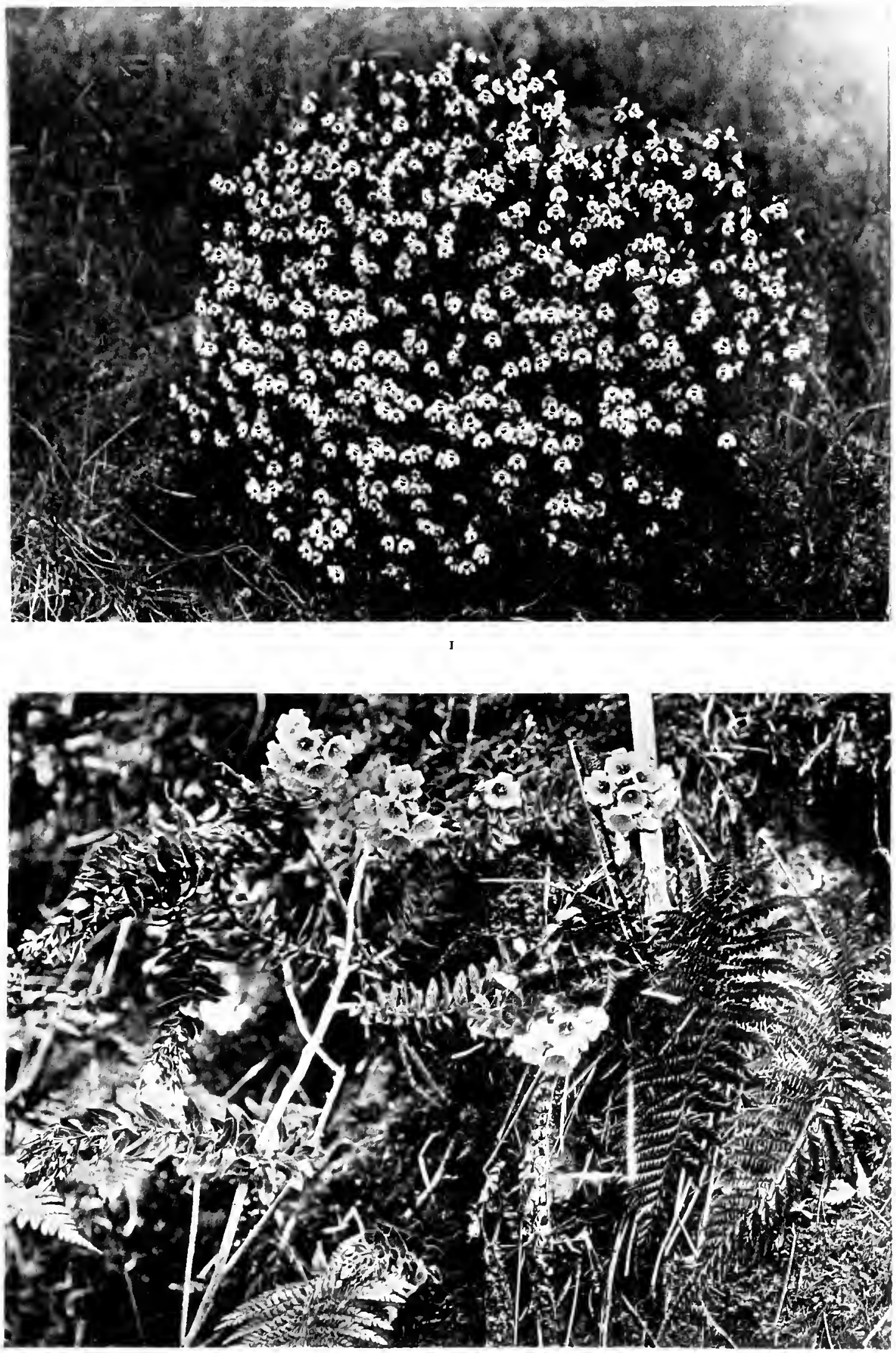



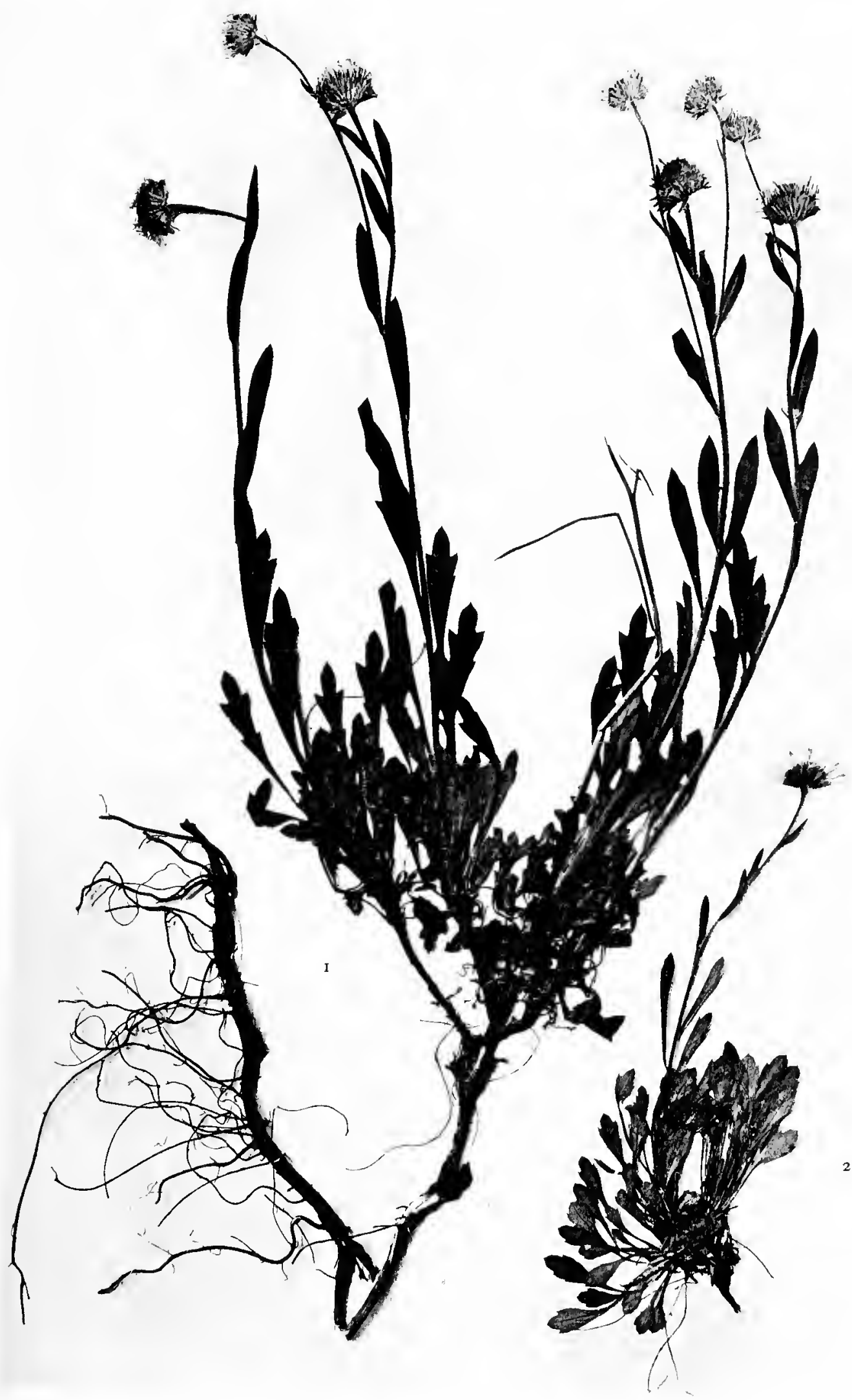







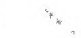




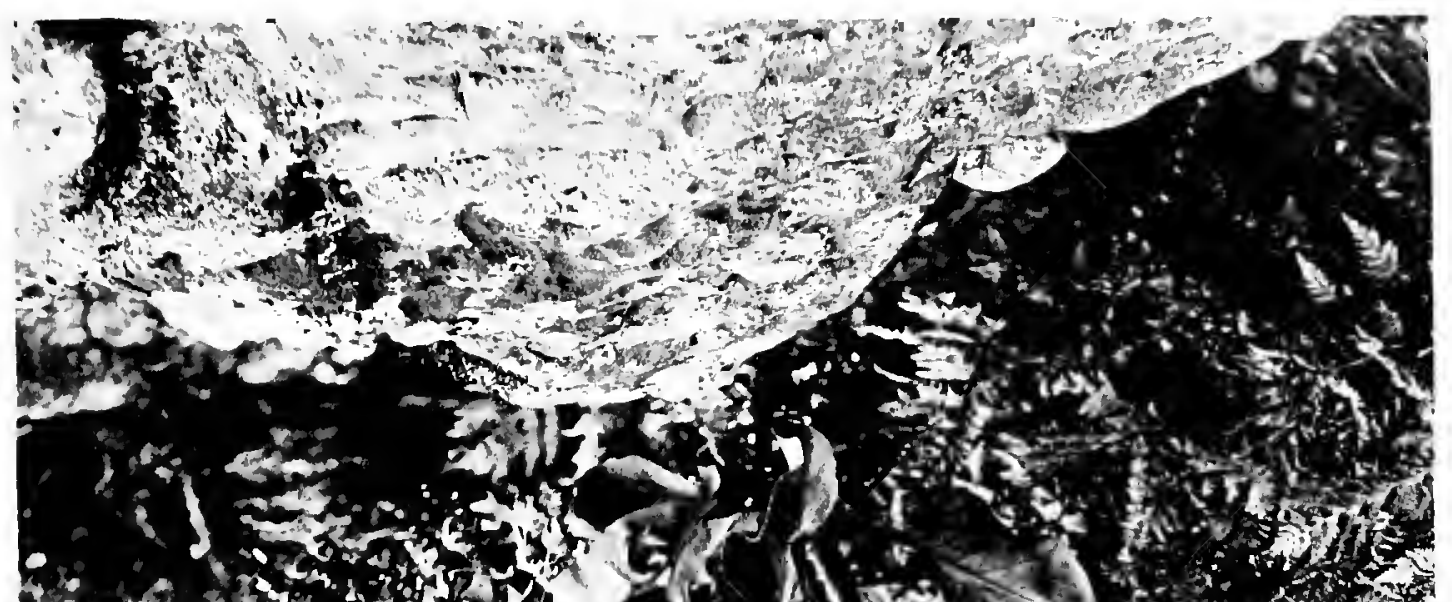

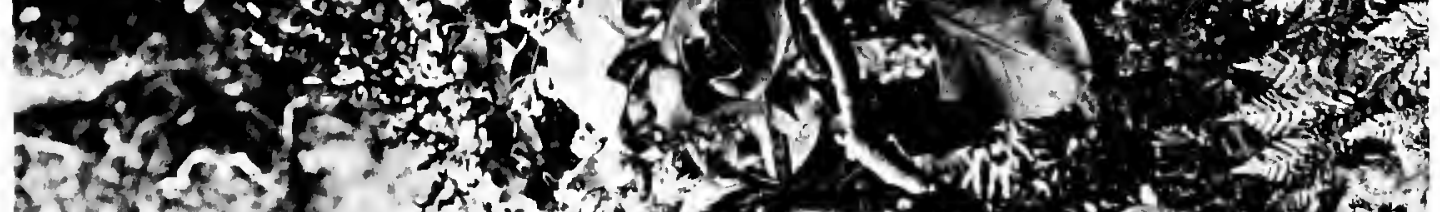

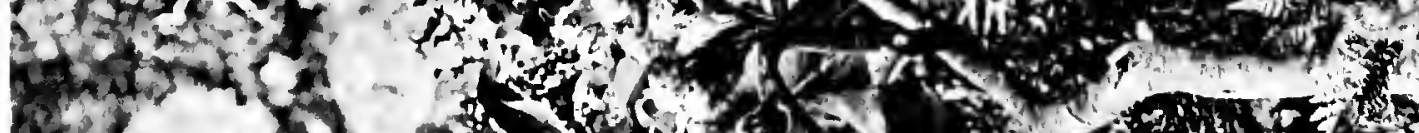

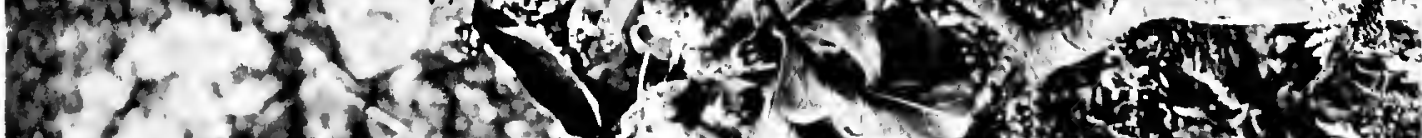

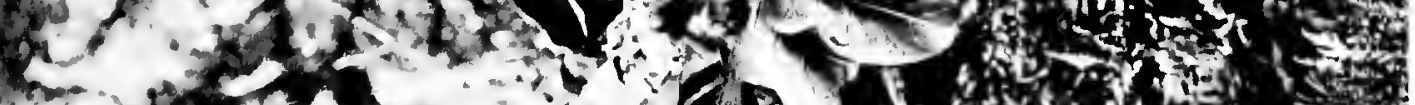

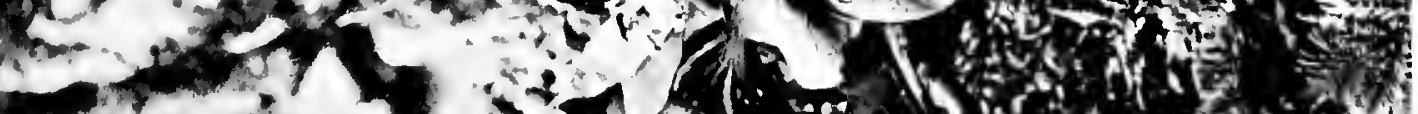

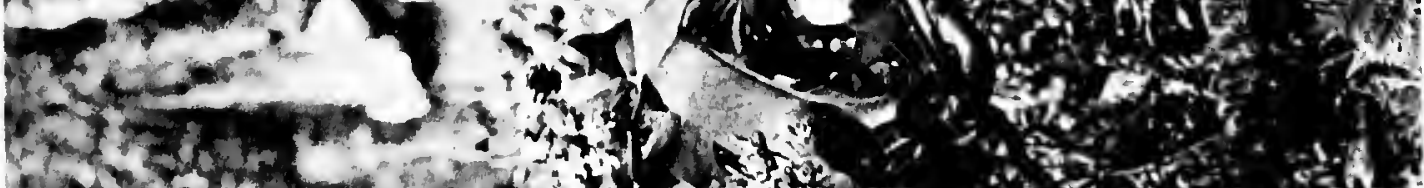

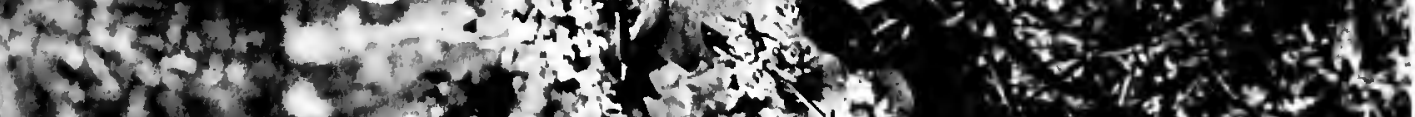

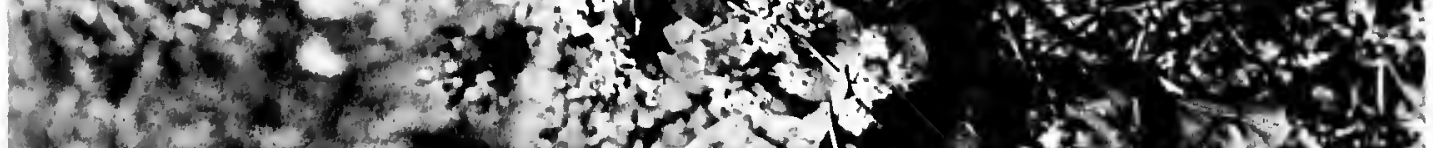

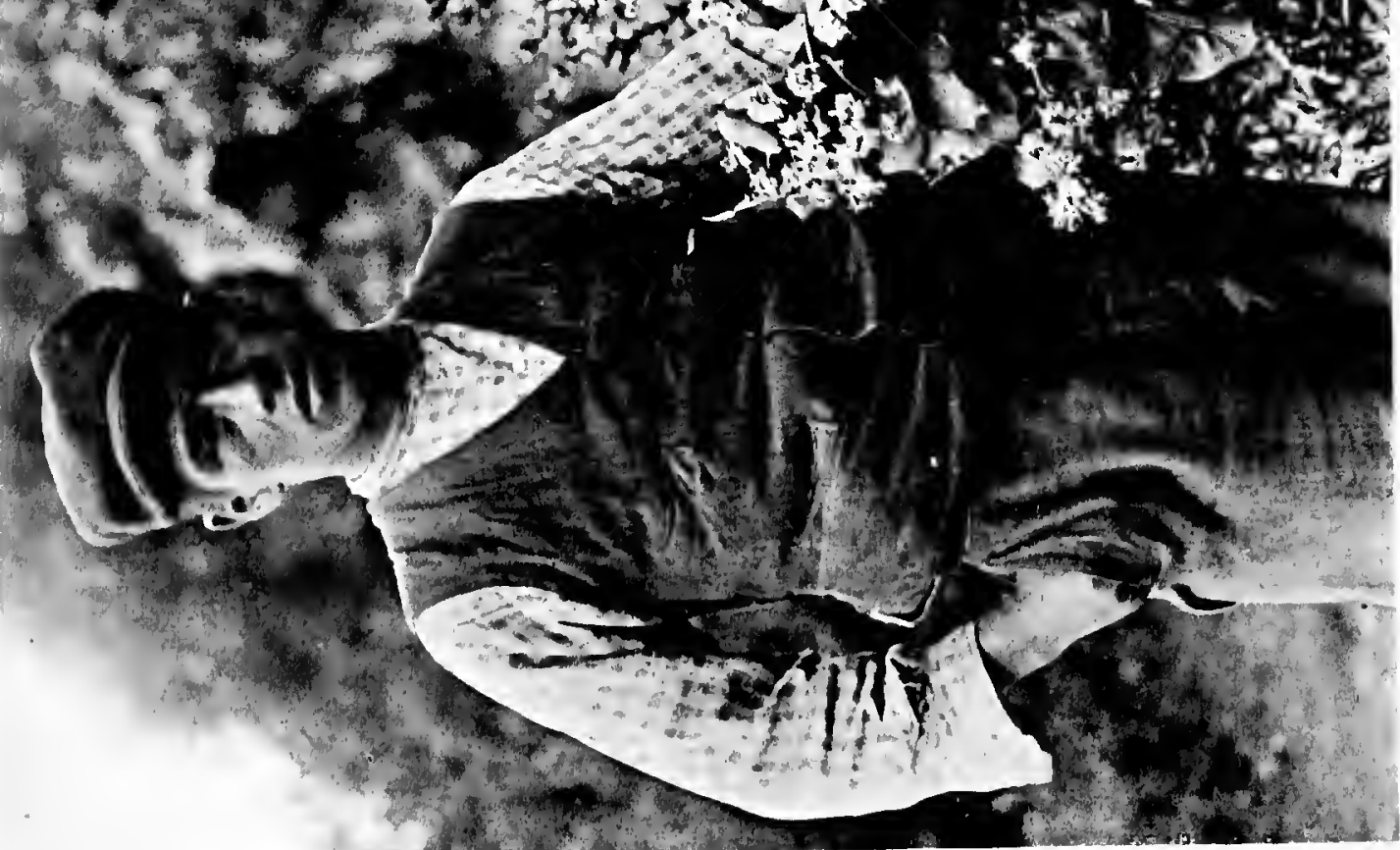


.

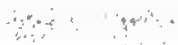




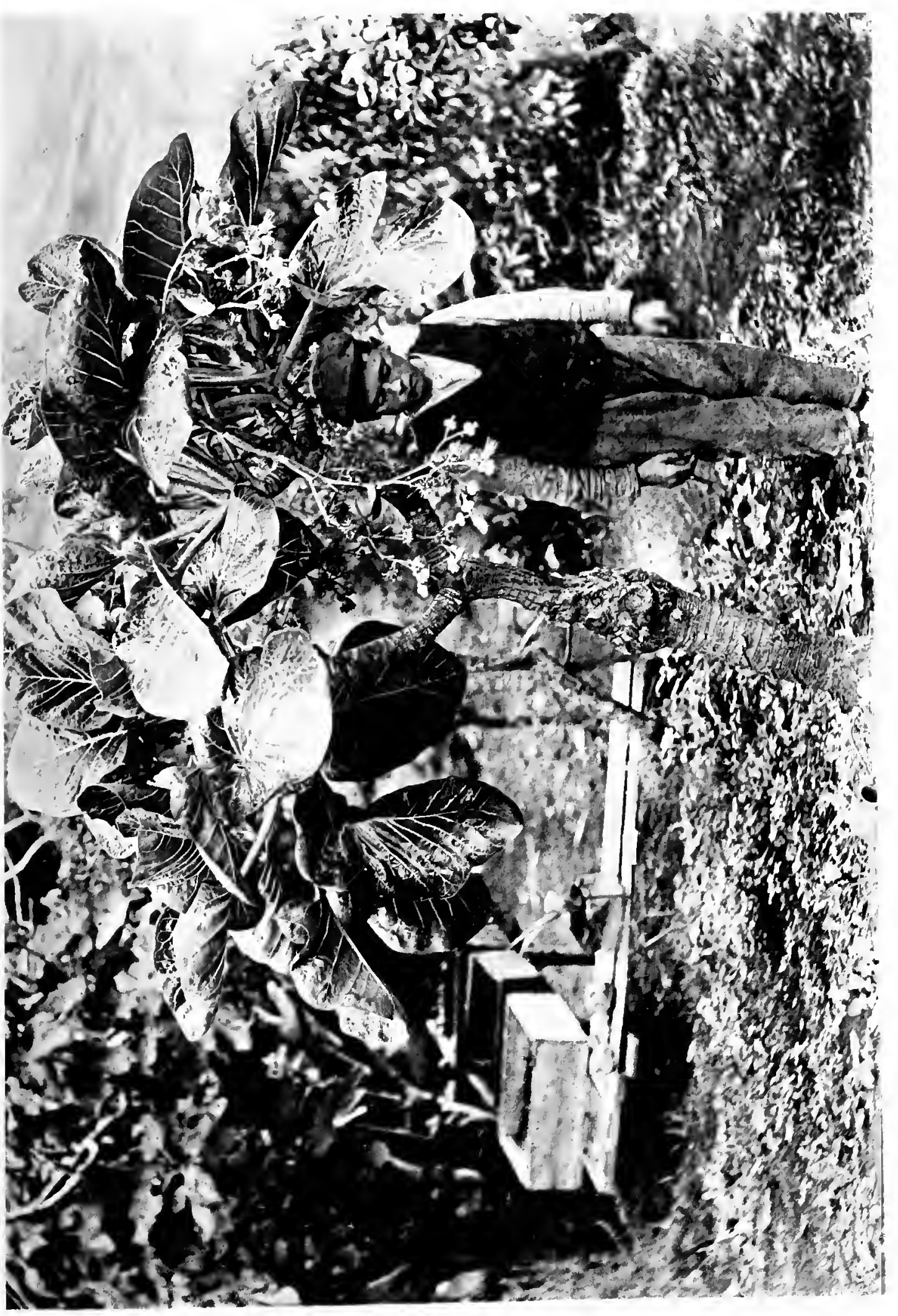



Nat. Hist. Fuan Fernandez and Easter Isl. Vol. II.

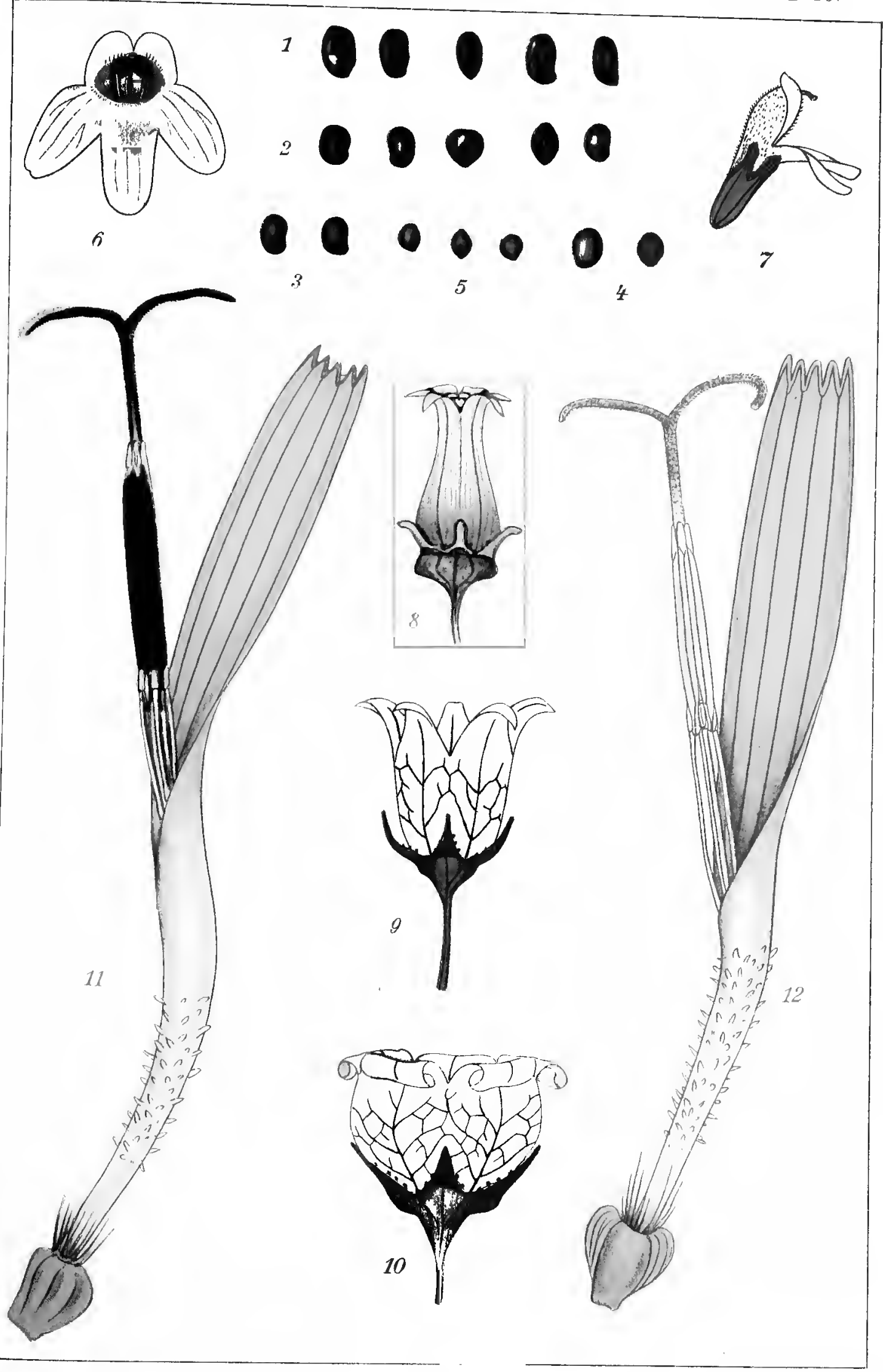




